\title{
Mal de amores en las Cartas eróticas de Filóstrato: teoría retórica y teoría epistolar
}

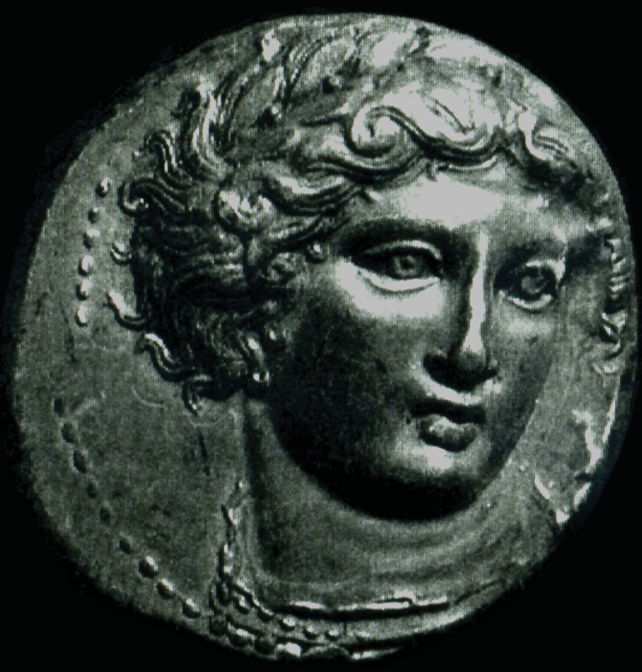

Ana Vicente Sánchez

MONOGRAFÍASDE FILOLOGÍA GRIEGA 20 
Mal de amores en las Cartas eróticas de Filóstrato:

teoría retórica y teoría epistolar 


\title{
Mal de amores en las Cartas eróticas de Filóstrato: teoría retórica y teoría epistolar
}

\author{
Ana Vicente Sánchez
}

MONOGRAFÍAS DE FILOLOGÍA GRIEGA, 20 • 2011 
FILÓSTRATO

Mal de amores en las «Cartas eróticas» de Filóstrato : teoría retórica y teoría epistolar / Ana Vicente Sánchez - Zaragoza : Prensas Universitarias de Zaragoza, 2011

164 p. ; $23 \mathrm{~cm}$. - (Monografías de filología griega ; 20)

Bibliografía: p. 157-164. - ISBN 978-84-92774-46-3

Filóstrato. Cartas eróticas-Crítica e interpretación

821.14’02-6Filóstrato7Cartas eróticas.09

Cualquier forma de reproducción, distribución, comunicación pública o transformación de esta obra solo puede ser realizada con la autorización de sus titulares, salvo excepción prevista por la ley. Diríjase a CEDRO (Centro Español de Derechos Reprográficos, www.cedro.org) si necesita fotocopiar o escanear algún fragmento de esta obra.

(C) Ana Vicente Sánchez

(C) De la presente edición, Prensas Universitarias de Zaragoza

1. ${ }^{\text {a }}$ edición, 2011

Colección Monografías de Filología Griega, 20

Diseño de cubierta: David Guirao

La edición de este volumen ha contado con la ayuda del Vicerrectorado de Investigación de la Universidad de Zaragoza

ISBN: 978-84-92774-46-3

ISSN: 1136-0860

D.L.: Z-145/2011

Impreso en España

Imprime: Servicio de Publicaciones de la Universidad de Zaragoza 


\title{
MONOGRAFÍAS DE FILOLOGÍA GRIEGA \\ Nueva etapa
}

(Publicación anual)

\section{CONSEJO EDITORIAL}

\author{
Director: Carlos Schrader García (Universidad de Zaragoza) \\ Director Ejecutivo: José Vela Tejada (Universidad de Zaragoza) \\ Secretario de Publicaciones: Vicente Ramón Palerm (Universidad de Zaragoza)
}

\section{COMITÉ CIENTÍFICO}

José Antonio Caballero López (Universidad de La Rioja), José Luis Calvo Martínez (Universidad de Granada), José $\mathrm{M}^{\mathrm{a}}$ Candau Morón (Universidad de Sevilla), Emilio Crespo Güemes (Universidad Autónoma de Madrid), José Antonio Fernández Delgado (Universidad de Salamanca), Carlos García Gual (Universidad Complutense de Madrid), José García López (Universidad de Murcia), Fernando García Romero (Universidad Complutense de Madrid), Manuel García Teijeiro (Universidad de Valladolid), Manuela García Valdés (Universidad de Oviedo), F. Javier Gómez Espelosín (Universidad de Alcalá de Henares), Juan Antonio López Férez (UNED - Madrid), Marcos Martínez Hernández (Universidad Complutense de Madrid), Antonio Melero (Universidad de Valencia), José Guillermo Montes Cala (Universidad de Cádiz), Juan José Moralejo Álvarez (Universidad de Santiago de Compostela), Anastasios Nikolaidis (Universidad de Creta, Grecia), Aurelio Pérez Jiménez (Universidad de Málaga), Emilio Suárez de la Torre (Universidad de Valladolid), Gocha R. Tsetskhladze (Universidad de Melbourne, Australia), Joana Zaragoza Gras (Universidad Rovira i Virgili de Tarragona)

Monografías de Filología Griega (MFG) publica un número al año. Los originales no solicitados deberán remitirse, al menos, a dos miembros del Comité Científico y a uno del Consejo Editorial, para poder proceder a su publicación una vez aprobada la misma. MFG mantendrá intercambio con cualquier publicación periódica que contenga aportaciones científicas originales relacionadas con el ámbito de los estudios de Filología Griega.

Redacción y Administración

Área de Filología Griega

Departamento de Ciencias de la Antigüedad

Facultad de Filosofía y Letras

Universidad de Zaragoza E-50009 Zaragoza

e-mail: schrader@posta.unizar.es

jvela@posta.unizar.es

vmramon@posta.unizar.es 


\section{MONOGRAFÍAS DE FILOLOGÍA GRIEGA}

\section{VOLÚMENES PUBLICADOS}

1. Ana MAGALLÓN y Vicente RAMÓN, Plutarco. 'Sobre la malevolencia de Heródoto', 1989, VII+105 págs. (agotado)

2. José VELA, Estudio sobre la lengua de la 'Poliorcética' de Eneas el Táctico, 1991, XIV+378 págs.

3. Vicente RAMÓN, Plutarco y Nepote. Fuentes e interpretación del modelo biográfico plutarqueo, 1992, VIII+301 págs.

4. Carlos SCHRADER, Arriano: 'Indiké'. Concordancia lematizada, 1994, XIII+491 págs. (reeditado, con modificaciones [Concordantia in Flavii Arriani Indicam Historiam], en ed. Olms, Hildesheim, 1995.)

5. Antonio LÓPEZ EIRE y Carlos SCHRADER, Los orígenes de la oratoria y la historiografía en la Grecia Clásica, 1994, 201 págs. (reimpreso en Hakkert, Las Palmas, 1997.)

6. Jorge BERGUA, Estudios sobre la tradición de Plutarco en España (siglos XIII-XVII), 1995, VIII+303 págs. (agotado)

7. Vicente RAMÓN, Estudios sobre Tucídides. Ensayo de un repertorio bibliográfico (1973-1995), 1996, 142 págs. (agotado)

8. Carlos SCHRADER, Vicente RAMÓN y José VELA (editores), Plutarco y la Historia. Actas del V Simposio Español sobre Plutarco (Zaragoza, 20-22 de junio de 1996), 1997, XII+506 págs.

9. Carlos SCHRADER, Carlos JORDÁN y José Antonio BELTRÁN (editores), DIDASKALOS. Estudios en homenaje al Profesor Serafín Agud con motivo de su octogésimo aniversario, 1998, XXVI+354 págs.

10. Carlos JORDÁN, Introducción al celtibérico, 1998, XI+259 págs. (agotado)

11. José VELA, Post. H.R. Breitenbach: Tres décadas de estudios sobre Jenofonte (1967-1997). Actualización científica y bibliográfica, 1998, VIII+224 págs.

12. Juan Francisco MARTOS MONTIEL, El tema del placer en la obra de Plutarco, 1999, 175 págs.

13. Rafael J. GALLÉ CEJUDO, El escudo de Neoptólemo. La paráfrasis filostratea del escudo de Aquiles (Philostr. Jun., Im. 10.4-20 - Hom., Il. 18.483-608), 2001, 155 págs.

14. Carlos SCHRADER, Los historiadores griegos del siglo V. Textos lematizados (Versión Macintosh), 2001, CD-ROM, edición no venal.

15. Jorge BERGUA, Introducción a los helenismos del español, 2002, 454 págs. (agotado)

16. Carlos JORDÁN, Celtibérico, 2004, IV+476 págs.

17. Ana VICENTE SÁNCHEZ, Las Cartas de Temístocles. Lengua y técnica compositiva, 2006, 484 págs.

18. Alberto BERNABÉ y Eugenio R. LUJÁN, Introducción al griego micénico. Gramática, selección de textos y glosario, 2006, 363 págs.

19. Francisco J. GONZÁLEZ PONCE, Periplógrafos griegos I. Épocas Arcaica y Clásica 1: Periplo de Hanón y autores de los siglos VI y V a.C., 2008, 288 págs. 

Monografías de Filología Griega 20 (2011)

Mal de amores en las Cartas eróticas de Filóstrato: teoría retórica y teoría epistolar

Área de Filología Griega. Departamento de Ciencias de la Antigüedad Facultad de Filosofía y Letras. Universidad de Zaragoza. ISSN: 1136-0860

\section{ÍNDICE}

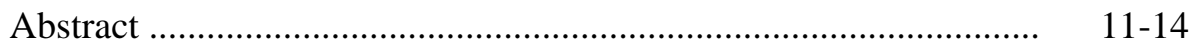

1. Introducción ........................................................................ 15-17

2. El autor de las Cartas: Filóstrato .............................................. 19-20

3. Filóstrato y la retórica ............................................................... 21-28

4. Mal de amores en las Cartas eróticas de Filóstrato: teoría retórica y teoría epistolar .............................................................. 29. 290

ANEXO. Mal de amores en las Cartas eróticas de Filóstrato. Selección de Cartas .................................................. 81-152

Introducción ...................................................................... 83-91

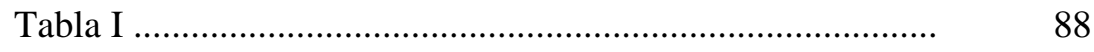

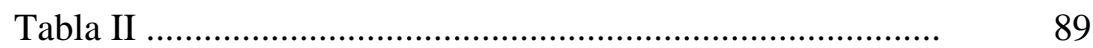

Tabla III ...................................................................... 90

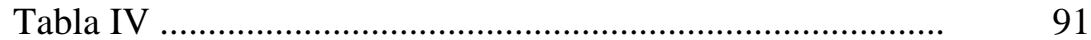

Selección de Cartas .............................................................. 93-141

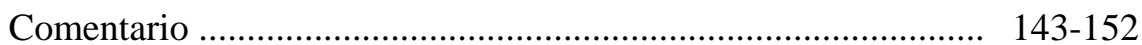

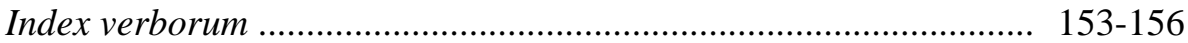

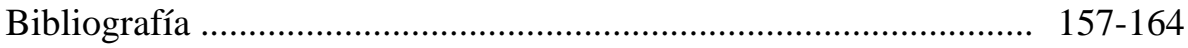

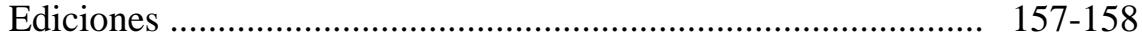

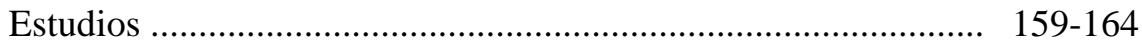



Monografías de Filología Griega 20 (2011)

Lovesickness in the Love Letters of Philostratus: Rhetorical Theory and Epistolary Theory

Área de Filología Griega. Departamento de Ciencias de la Antigüedad Facultad de Filosofía y Letras. Universidad de Zaragoza. ISSN: 1136-0860

\section{CONTENTS}

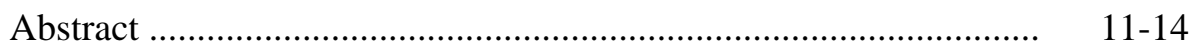

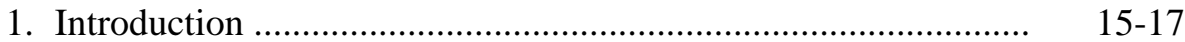

2. The Author of the Letters: Philostratus ........................................ 19-20

3. Philostratus and Rhetoric ......................................................... 21-28

4. Lovesickness in the Love Letters of Philostratus: Rhetorical Theory and Epistolary Theory ...................................................... 29. 29-80

ANNEX. Lovesickness in the Love Letters of Philostratus.

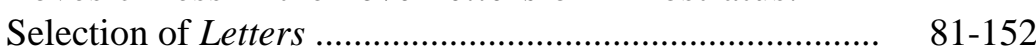

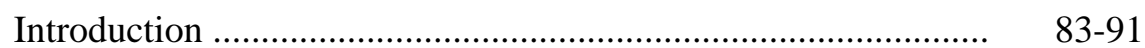

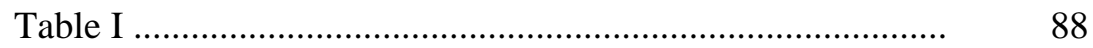

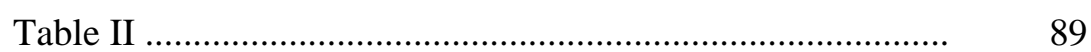

Table III .........................................................................

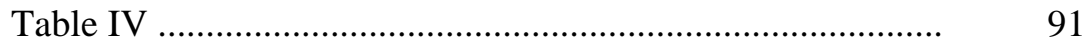

Selection of Letters ..................................................... 93-141

Commentary ..................................................................... 143-152

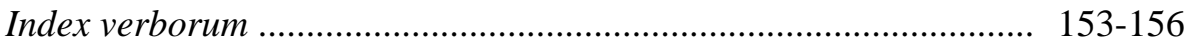

Bibliography ............................................................................ 157-164

Editions .............................................................................. 157-158

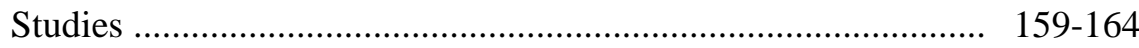





\begin{abstract}

\section{Introduction}

Literary works of the Second Sophistic generally show a strong influence of the rhetorical education their authors received. This study will show this trace of theory in a special genre, namely epistolography, which has sometimes been considered free of doctrinal limits. It will specifically examine the methods used to express love troubles in a collection of love letters attributed to Philostratus.
\end{abstract}

\title{
2. The Author of the Letters: Philostratus
}

Tradition has left us with a number of works which have been attributed to different Philostrati, whom critics have tried to identify in several ways.

The Suda, for instance, mentions three literary figures named Philostratus, all from Lemnos and related to each other by family ties. The most commonly accepted idea attributes the collection of letters to the author of Gymnasticus, The Life of Apollonius of Tyana and Lives of the Sophists, among other works. This would be the second of the Philostrati, who carried out his sophistic and literary activities from the end of the 2nd century to the beginning of the 3rd.

Although the letters are independent of each other, some features, such as the use of one and the same theme for both male and female recipients, suggest a unified composition for most of them.

\section{Philostratus and Rhetoric}

Philostratus II received a thorough rhetorical education, carried out his sophistic activities first in Athens and then in Rome, and gave the cultural movement he belonged to its name: the Second Sophistic. 
In order to examine the influence of rhetoric on his writing, these Love Letters were analyzed from the perspective of the following works which cover the period from the 4th century BC until the 5th century: Aristotle's Rhetoric and the one attributed to Anaximenes, the so-called Anonymous Seguerianus, the rhetoric treatise of Apsines of Gadara, the anonymous On Sublimity, Hermogenes' On Types of Style, Demetrius' On Style, the manuals on types of letters Epistolary Types and Epistolary Characters, the Letter to Aspasius of Ravenna of Philostratus of Lemnos, some commentaries included in Philostratus' Lives of the Sophists and the series of manuals with exercises of Aelius Theon, Hermogenes, Aphthonius the Sophist and Nicolaus of Myra.

\section{Lovesickness in the Love Letters of Philostratus: Rhetorical Theory and Epistolary Theory}

This chapter analyzes the influence of rhetoric on the writing of the Love Letters by means of the three traditional internal or artistic arguments of Aristotle that have remained in rhetorical theory for centuries: the ability of transmitting ways of being and emotions through an adequate style (ethos, pathos and logos).

These elements, apart from lasting in rhetorical treatises, are also found in style manuals and in the Progymnasmata. Among the exercises carried out at rhetoric schools, the so-called prosopopoeia or ethopoeia turned out to be especially suitable for letter writing. Moreover, also included in rhetorical education and closely related to this exercise, there is the funeral oration, which, in general, concerned the loss of a loved one or a city, although there are also examples of laments on nearly any topic.

This chapter consists of three parts. In the first place, the study of ethos in the Letters, secondly that of pathos, and finally, style. In each part we will detect the application of the acquired rhetoric, which played such an important role in every day life in the Roman empire. 


\section{Annex. Lovesickness in the Love Letters of Philostratus. Selection of Letters}

\section{Introduction, Selection of Letters and Commentary}

The second part of this book contains the Love Letters that express lamentation or mourning. It shows the Greek text as well as its Spanish translation.

The selection of Letters follows an introduction which explains the existence of two families of manuscripts that show different versions of the Letters. The main difference between them consists of the order in which the Letters are presented, whether the recipient is male or female and the text itself, which in manuscript family 1 is an abbreviated version. This introduction gives account of how the most significant editors have interpreted this double version. The editions used in this study are those of G. Olearius, J. F. Boissonade, C. L. Kayser, A. Westermann, R. Hercher and A. R. Benner \& F. H. Fobes (these editions are briefly described in the following Table IV). However, a new and modern edition which would study and compare all the manuscripts that transmit the Letters is wished for, as is made clear by the important work of D. K. Raïos.

The introduction concludes with four tables showing the pairs of Letters that share the same theme and distinguish between male and female recipients (Table I), the order in which they were transmitted by manuscript family 2 (Table II) and (Table III) the Letters with the numbering of C. L. Kayser and their page in this book (Kayser's numbering has been maintained, but in this selection the Letters are presented according to family 2 , since it groups them together according to their themes and also alternates male and female recipients).

Following the Greek and Spanish versions of the Letters, there is a chapter with notes that comment upon the several textual problems or differences from the edition of A. R. Benner \& F. H. Fobes that appear asterisked in their corresponding paragraphs. 


\section{Index verborum}

This index lists the most significant terms, authors and characters of this study.

\section{Bibliography}

The bibliography has been divided into two parts. First, it shows the editions used for the ancient texts, both of Philostratus' work as well as that of other authors, and secondly, there is a list of studies, monographs and articles used in this research. 


\section{INTRODUCCIÓN}

Las composiciones literarias de la Segunda Sofística muestran, por lo general, una fuerte influencia de la formación retórica que habían recibido sus autores. El presente estudio ${ }^{1}$ pretende mostrar esa huella teórica en un género especial, la epistolografía, que en ocasiones se ha considerado libre de los límites doctrinales. ${ }^{2}$ En concreto se van a indagar los medios empleados para manifestar las cuitas amorosas en una colección de cartas de tema erótico-amoroso atribuida a Filóstrato. Se continúa, de este modo, el seguimiento de la técnica compositiva en esta particular epistolografía desde el punto de vista de la forma de expresión del lamento: ${ }^{3}$ anteriores a éstas, conservamos las Cartas de Alcifrón y Eliano que conforman, junto a las posteriores colecciones de Aristéneto y Teofilacto, el corpus esencial en griego de epistolografía erótico-amorosa de la Antigüedad Tardía. Comoquiera que dicho tópico en los dos primeros autores ya ha sido

\footnotetext{
1 Este trabajo se ha realizado bajo los auspicios del Proyecto de Investigación HuM 2007-64772 (de la Dirección General de Enseñanza Superior e Investigación Científica) y del Grupo Investigador «Byblíon» H 52 (financiado por la Dirección General de Investigación, Innovación y Desarrollo, Consejería de Ciencia y Tecnología, DGA). Igualmente debe mencionarse el Programa Europa XXI de Estancias de Investigación (DGA -CONAID- y CAI) y la helvética Fondation Hardt. Quisiera mostrar mi agradecimiento desde estas líneas a todas aquellas personas que pacientemente han atendido mis consultas y cuyas sugerencias han sido siempre atinadas y brillantes.

2 Sobre el género epistolar y su definición, vid., por ejemplo, A. López Eire, 1998, pp. 319 ss. La retórica influyó desde antiguo sobre la preceptiva y la composición epistolar (vid. A. Garzya, 1985, pp. 364 s.; E. Suárez de la Torre, 1988, pp. 177 ss.; R. J. Gallé Cejudo, 1997, p. 216; A. Vicente Sánchez, 2006, pp. 372 ss.) Sobre la retórica y las Cartas de Filóstrato, vid. J. Elsner, 2009, pp. 6 ss.

3 Sobre la epistolografía griega de tema erótico-amoroso, su definición y circunscripción, vid. E. Suárez de la Torre, 1991, pp. 113 ss., y R. J. Gallé Cejudo, 1999, pp. 26 s. y 34 s.
} 
estudiado, ${ }^{4}$ servirá esta nueva exposición para trazar un esbozo en la historia de este género y en su relación con la retórica.

En líneas generales, estas colecciones concurren en una serie de rasgos que pueden responder parcialmente a la aplicación de una teoría aprendida, la de la retórica griega. Y es que este género epistolar gozaba de particular fortuna desde Época Helenística, de modo que a finales de dicho período comenzó a ser objeto de estudio en las escuelas de retórica, especialmente como ejercicio de estilo. ${ }^{5}$ En consecuencia, suele considerarse que sobre la epistolografía literaria de la Antigüedad Tardía ejerció una gran influencia la retórica, cuya proyección se reflejaba en todas las formas artísticas y literarias contemporáneas; asimismo, se observa un evidente influjo de la preceptiva epistolar desde el siglo I a. C. ${ }^{6}$ Tanto es así que estos epistolarios se ponen en relación con la práctica en las escuelas de retórica de determinados ejercicios preparatorios, y, sobre todos ellos, con la prosopopeya o etopeya. ${ }^{7}$

A continuación del estudio sobre la composición de las Cartas eróticas que expresan lamento o queja, se ofrece el texto griego y la traducción al español $^{8}$ de esa selección temática. Precede a los textos una introducción que da cuenta de las diferentes versiones que existen de este corpus epistolar y de las distintas interpretaciones que hasta la fecha se han emitido. El texto griego $^{9}$ de las Cartas empleado en este estudio pertenece a la edición de A. R. Benner \& F. H. Fobes, 1962 (=1949), sobre el que se ha realizado alguna

Vid. A. Vicente Sánchez, 2004 y 2007.

Vid. G. A. Privitera \& R. Pretagostini, 1997, pp. 758 s.; P. Cugusi, 1990, p. 397.

Vid. A. Garzya, 1985, pp. 352 ss. y 364 ss. En general, se cree que la teoría epistolar se desarrolló y divulgó tempranamente -vid. J. L. White, 1986, p. 189; E. Suárez de la Torre, 1988, pp. 177 y 192; R. J. Gallé Cejudo, 1997, pp. 215 s.-. Sin embargo, para G. Scarpat, 1972, pp. 477 s., no existía una auténtica teoría sobre el género epistolar en la Antigüedad.

J. Bompaire, 1958, pp. 203-221; J. Ureña Bracero, 1993, p. 267 ss., 290, especialmente para Alcifrón en p. 277; R. J. Gallé Cejudo, 1997, p. 216; A. Vicente Sánchez, 2004, pp. 72 ss, 81 s., 85, 86 s., 95, y 2007, pp. 470 ss.

Una vez enviado este volumen a Prensas Universitarias de Zaragoza ha aparecido una traducción al español del corpus epistolar completo atribuido a Filóstrato a cargo del Profesor R. J. Gallé Cejudo en la editorial Gredos (Filóstrato, Cartas de amor. Aristéneto, Cartas, Madrid, 2010), que no se ha podido utilizar ni consultar para la realización de nuestro estudio y traducción; sin embargo, resulta sumamente recomendable su lectura y consulta, dada la calidad y excelencia del trabajo del Dr. R. J. Gallé Cejudo.

9 Acerca de las distintas ediciones vid. la introducción que precede a la selección de Cartas.

Monografías de Filología Griega 20. ISSN 1136-0860 
modificación, cuyo fundamento se expone en el siguiente apartado de comentario; y, asimismo, se ha añadido una división en párrafos al texto para facilitar su consulta. 



\section{EL AUTOR DE LAS CARTAS: FILÓSTRATO}

El léxico bizantino de la Suda menciona tres figuras literarias con el nombre de Filóstrato, ${ }^{10}$ relacionadas entre sí mediante algún vínculo familiar y procedentes de Lemnos. Asimismo distribuye entre ellos las distintas obras que se nos han transmitido con esta firma así como otras perdidas. Los comentarios de Focio no coinciden exactamente con los datos de la Suda, algo que induce a J. J. Flinterman a pensar que la identidad y la producción literaria de los diferentes Filóstratos era fuente de confusión para los estudiosos bizantinos de los siglos IX y X. Y es que esta cuestión nebulosa sigue siendo tema debatido, sin estar definitivamente zanjado de modo taxativo.

Respecto del objeto de estudio de este trabajo, la propuesta más común atribuye la colección de cartas al autor del Gimnástico, de la Vida de Apolonio de Tiana y de las Vidas de sofistas, entre otras, que sería el segundo de los Filóstratos, si bien no puede descartarse que alguna de las Cartas perteneciera a cualquiera de los otros homónimos, ${ }^{11}$ o que, fuera cual fuese su autor, se uniera a la colección por la proximidad temática y formal. ${ }^{12}$ Sin embargo, aunque son cartas independientes, algunas de sus características hacen suponer una composición unificada para la mayoría de ellas, como la puesta en práctica de una misma temática para sendos destinatarios, masculinos y femeninos.

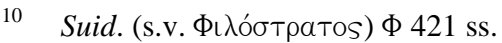

11 Vid., por ejemplo, J. S. Phillimore, 1912, pp. Xxxiv ss., o K. Münscher, 1907, pp. 515 ss. y 524 ss.; si bien puede leerse un resumen de las distintas interpretaciones que se han realizado en J.-J. Flinterman, 1995, pp. 5 ss. o en L. de Lannoy, 1997 pp. 2363 ss.; vid. también L. de Lannoy, 1997 pp. 2438 ss.; A. Billault, 2000, pp. 5 ss.; T. Whitmarsh, 2007, pp. 31 ss.; E. Bowie, 2009, pp. 19 ss. y 31; S. Goldhill, 2009, pp. 287 s.

12 Piénsese en el caso de las Imágenes, emuladas por un segundo autor, o las Vidas de sofistas, modelo para Eunapio (vid. J. Elsner, 2009, pp. 6 s.), con lo que podría colegirse lo mismo de las Cartas eróticas. 
Del autor de las Cartas se sabe, de acuerdo con la más habitual interpretación, que pasó parte de su juventud en Lemnos y que quizá nació allí. Estudió retórica en Atenas y fue discípulo, con seguridad, de Proclo de Náucratis; otros nombres se barajan entre sus maestros, como Damiano de Éfeso y Antípatro de Hierápolis. Además de Atenas, es posible que visitara otros centros de formación retórica en Asia Menor, como Éfeso o Esmirna. La Suda nos dice que desarrolló su actividad sofista primero en Atenas y después en Roma. Y en cuanto a las fechas de su biografía, ${ }^{13}$ resultan un tanto vagas, pero parece que desarrollaría su labor entre finales del siglo it y principios del siguiente. $^{14}$

13 Para las fuentes y los distintos argumentos que se manejan a fin de establecer cierta cronología, vid. J.-J. Flinterman, 1995, pp. 15 ss.

14 Vid., sobre la cronología, J. Elsner, 2009, p. 4; E. Bowie, 2009, p. 20. 


\section{FILÓSTRATO Y LA RETÓRICA}

La relación de Filóstrato con la retórica fue estable y duró toda su vida, tanto en su actividad profesional como en la literaria. Estuvo en los grandes centros donde se desarrollaba la sofística retórica, y fue maestro en Atenas y Roma, donde, además, mantuvo un contacto directo con la corte imperial y la elite cultural griega y romana. ${ }^{15} \mathrm{La}$ importancia de Filóstrato en este ambiente es considerable, hasta el punto de que él mismo da nombre al movimiento cultural al que pertenece. ${ }^{16}$

Las características singulares del objeto de estudio que nos ocupa, la expresión del lamento en las cartas eróticas griegas, hacen que nos fijemos especialmente en una serie de obras del entorno de la retórica que pueden ayudarnos a comprender la forma de composición y la influencia que esta ejercía sobre la obras literarias. ${ }^{17}$ Por lo tanto, antes de pasar al desarrollo de las cuestiones específicas que conciernen a este estudio, haremos brevemente referencia a algunas de las obras básicas para llevar a cabo esta investigación y que, a su vez, no resultan excesivamente conocidas. Por ello, aunque se utilizan y su influencia en las obras posteriores es fundamental, no vamos a demorarnos en las retóricas de Anaxímenes y Aristóteles, puesto que son harto conocidas y sobre ellas existe una extensa bibliografía. ${ }^{18}$

Sin embargo sí que vamos a detenernos en otras obras más próximas en el tiempo a la época de Filóstrato y, por otra parte, menos conocidas, como

15 A. Billault, 2000, pp. 9 ss. y 19 ss.; E. Bowie, 2009, pp. 24 s.

16 En su obra Vidas de sofistas (I 480-484) acuñó el término «Segunda Sofística» como una retórica que trata temas concretos, diferente de la primera, que se dedicaba a la filosofía.

17 El género epistolar se caracteriza por su capacidad para absorber los rasgos propios de cualquier otro género y adaptarlos a su formato. Vid. sobre ello E. Suárez de la Torre, 1988, pp. 181 s.; R. J. Gallé Cejudo, 2001, pp. 49 s.

${ }_{18}$ Para sus obras se siguen las ediciones de M. Fuhrmann, 1966, y W. D. Ross, 1975, respectivamente. 
el llamado Anónimo Segueriano, un epítome de varias fuentes que se remontan a mediados del siglo II, de las que el autor anónimo se sirvió aproximadamente unos cincuenta años más tarde. Este tratado se había considerado largo tiempo un epítome de una obra perdida del retórico Cornuto del siglo III, pero actualmente se adelanta su composición y M. R. Dilts y G. A. Kennedy lo atribuyen a un estudiante que, a mediados del siglo II o en su segunda mitad, compiló diferentes puntos de vista de fuentes anteriores sobre inventio y dispositio retóricas. ${ }^{19}$

Igualmente puede mencionarse a Apsines de Gádara, citado en ocasiones como Apsines el Fenicio, que fue profesor de retórica en Atenas. Podría situarse con cierta seguridad en la primera mitad del siglo $\mathrm{III}^{20}$ porque precisamente Filóstrato lo menciona en sus Vidas de sofistas. Al final de la obra comenta el autor su decisión de no escribir acerca de Nicágoras de Atenas ni de Apsines el Fenicio, ya que les unía una relación de amistad:

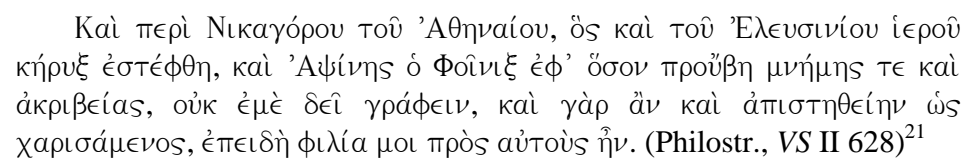

Apsines compuso un manual de corte tradicional que continuaba alguna de las directrices marcadas ya por la retórica aristotélica, al igual que el Anónimo Segueriano. ${ }^{22}$ Cuando habla del epílogo en el capítulo décimo de su Retórica, incluye Apsines un significativo apartado dedicado a la

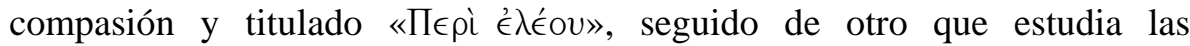

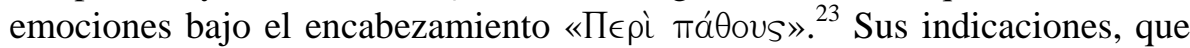
reflejan las teorías vigentes en la época, nos van a resultar útiles para el

19 Cf. M. R. Dilts \& G. A. Kennedy, 1997, pp. XI ss. Vid. también A. G. Kennedy, 1972, pp. 616 ss., y la más reciente edición de M. Patillon, 2005, de la que proceden los textos aquí citados, aunque puede consultarse igualmente con la misma numeración L. Spengel \& C. Hammer, 1894, y M. R. Dilts \& G. A. Kennedy, 1997.

20 Kennedy, 1972, pp. 633 s.; M. Patillon, 2002a, pp. VII ss.

21 Edición de W. C. Wright, 1961.

22 G. A. Kennedy, 1994, pp. 63 y 226, y la edición de sendos textos de M. R. Dilts y G. A. Kennedy, 1997, pp. X ss. y XV ss.

23 Cf. M. R. Dilts \& G. A. Kennedy, 1997, pp. X ss. y XV ss. La edición que se ha seguido en este trabajo es la de M. Patillon, 2002a, que conserva al margen la numeración de la antigua de L. Spengel y C. Hammer, 1894, lo mismo que M. R. Dilts \& G. A. Kennedy, 1997 (se citan los parágrafos correspondientes al capítulo décimo relativo al epílogo). 
estudio de los recursos utilizados en las Cartas a la hora de expresar lamento.

Además conservamos referencias sobre los distintos estilos apropiados a cada expresión, entre las que podemos destacar la obra Sobre lo sublime, un Arte retórica atribuida al orador Aristides y un tratado de Hermógenes dedicado a las formas de estilo. Sobre lo sublime, de cuya discutida autoría nada va a comentarse, resulta ubicado en los últimos estudios, merced a su estilo, a las citas y a las referencias del propio tratado, ${ }^{24}$ en la primera mitad del siglo I. ${ }^{25}$

Nos han llegado dos libros de Arte retórica, falsamente atribuidos largo tiempo al orador Elio Aristides, uno relativo al discurso político y otro al simple. La doctrina que exponen sobre las categorías del estilo parece transmitir una teoría anterior a la citada obra de Hermógenes, por lo que podría establecerse un terminus ante quem hacia finales del siglo II o principios del siguiente. ${ }^{26}$

Entre los siglos II y III vivió Hermógenes, quien, además de dedicarse en su juventud a la oratoria, compuso tratados retóricos, según nos cuenta el propio Filóstrato en sus Vidas de sofistas (II 577-8). La obra que aquí nos interesa es la titulada Sobre las formas de estilo. Consta de dos libros en los

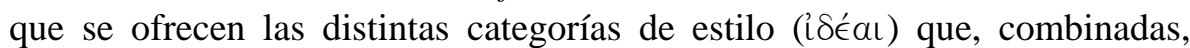
constituyen los estilos apropiados a cada género literario. ${ }^{27}$ De esas formas de estilo interesa destacar para los efectos de este estudio, como no podía ser de otra manera, la sencillez, claridad, dulzura y belleza. El corpus que tradicionalmente se atribuía a Hermógenes ${ }^{28}$ incluía un manual de progymnasmata, hoy día considerado espurio, sobre el que se hablará unas líneas más abajo.

24 Piénsese, por ejemplo, en la polémica con los escritos de Cecilio de Caleacte (vid. Longin. I) y en la referencia a la crisis de la elocuencia, característica de la época mencionada. Las citas corresponden a la edición de D. A. Russell, 1986, aunque puede consultarse igualmente la de J. Alsina Clota, 1985.

${ }_{25}$ Cf. G. A. Kennedy, 1972, pp. 369 ss.; J. Alsina Clota, 1985, pp. 19 ss.; D. A. Russell, 1995, pp. 54 ss., y 1989, pp. 306 ss.; D. C. Innes, 1990, pp. 694 ss.; J. García López, 1988, pp. 1005 ss.; M. A. R. Habib, 2005, pp. 118 ss.

26 Vid. M. Patillon, 2002b, a cuya edición pertenecen los textos aquí citados.

27 Vid. D. Hagedorn, 1964; G. A. Kennedy, 1972, pp. 619 ss.; D. A. Russell, 1995, pp. 140 ss., y 1989, pp. 315 ss.; C. Wooten, 1987; M. Patillon, 1988 y 1997b.

28 La edición empleada para las obras de Hermógenes es la de H. Rabe, 1913. 
Por otra parte, encontraremos referencias al estilo epistolar en un tratado

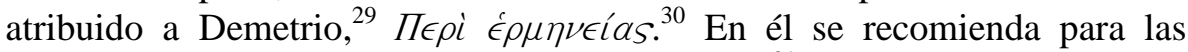
cartas una mezcla de los estilos simple y elegante, ${ }^{31}$ por lo que será necesario tener en cuenta sus indicaciones sobre cada uno de esos estilos. Del ámbito teórico de la epistolografía nos han llegado, además, dos manuales prácticos

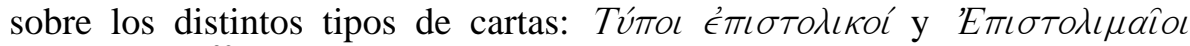
$\chi \alpha \rho a \kappa \tau \hat{\eta} \rho \in S^{32}{ }^{32}$ De autoría incierta -aunque se cite con frecuencia a Demetrio como su autor-, el primero suele datarse entre los siglos II/I a. C. ${ }^{33}$ y se cree que en Grecia existirían tempranamente manuales similares a este procedente de Egipto. El segundo, que goza de dos tradiciones manuscritas atribuidas a Libanio la una y a Proclo la otra, se fecha entre los siglos IV y VI. ${ }^{34}$ En estos tratados se refleja la evolución y desarrollo que esta tipología experimentó desde los veintiún tipos de la primera obra a los cuarenta y uno de la segunda. ${ }^{35}$

$\mathrm{Y}$ es preciso destacar, entre los distintos comentarios al estilo epistolar transmitidos en composiciones literarias, ${ }^{36}$ la llamada Carta a Aspasio de Ravena, la primera de las dos dialexeis ${ }^{37}$ que nos han llegado con la firma de

29 Tradicionalmente se creía una obra de Demetrio Falereo, pero la crítica coincide en considerarla espuria y suele hacer referencia a su autor simplemente como «Demetrio»; cf. E. Suárez de la Torre, 1979, pp. 31 s.; G. A. Kennedy, 1963, pp. 285 ss., 1983, pp. 71 s., y 1989, pp. 196 ss.; A. J. Malherbe, 1988, p. 2.

30 La interpretación de los datos que tenemos acerca de este manual da pie a distintas dataciones del mismo: desde el siglo III a. C. -cf. G. M. A. Grube, 1961, pp. 39 ss., 56 s., 133 ss.; G. Morpurgo-Tagliabue, 1980, pp. 141 ss. y 146 ss.; E. Suárez de la Torre, 1988, p. 189-, hasta seis siglos más tarde -cf. W. R. Roberts, 1969, pp. 49 ss.; D. M. Schenkeveld, 1964, p. 147 s.; K. Thraede, 1970, pp. 19 ss.; G. A. Kennedy, 1997, p. 27; W. Wuellner, 1997, p. 64-, si bien una fecha cercana al cambio de era o al siglo I parece la propuesta mejor argumentada.

31 Demetr., Eloc. 235, edición de P. Chiron de 1993.

32 Ambos textos siguen la edición de V. Weichert de 1910.

33 Cf. A. Brinkmann, 1909, pp. 313 ss.; V. Weichert, 1910, pp. XVII ss.; H. Koskenniemi, 1956, pp. 20 y 54 ss.; J. L. White, 1986, pp. 189 ss.; A. J. Malherbe, 1988, pp. 4 ss.; E. Suárez de la Torre, 1988, pp. 191 ss.

34 E. Suárez de la Torre 1988, p. 197 (vid. también 1979, pp. 34 s.) señala su composición en torno al siglo v; vid. asimismo H. Rabe, 1909, p. 294; V. Weichert, 1910, pp. XXV ss. y XLII s.; H. Koskenniemi, 1956, pp. 56 s.; H. Hunger, 1978, p. 200; G. A. Kennedy, 1983, pp. 71 s.; A. J. Malherbe, 1988, p. 5; J. T. Reed, 1997, pp. 174 s.

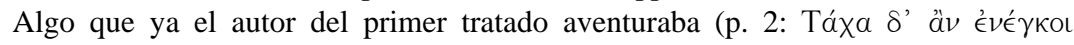

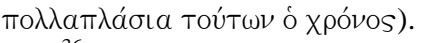

36 Vid. sobre ellas en general H. Koskenniemi, 1956, pp. 19 ss.; E. Suárez de la Torre, 1979, pp. 31 y 36 s.

37 Acerca de ellas vid. E. L. Bowie, 2009, p. 31; S. Swain, 2009, pp. 41 ss.

Monografías de Filología Griega 20. ISSN 1136-0860 
Filóstrato. ${ }^{38}$ En este caso parece que podría atribuirse su autoría al tercer Filóstrato -de Lemnos- mencionado por la $S u d a,{ }^{39}$ que sería un sobrino y yerno del segundo, el autor de la Vida de Apolonio de Tiana y las Vidas de sofistas, entre las que, por cierto, se cuenta la figura de Aspasio de Ravena y se hace referencia a las diferencias que mantenía con Filóstrato de Lemnos así como a la composición de esta carta. ${ }^{40}$ Este texto gozó en la Antigüedad de cierta popularidad, ${ }^{41} \mathrm{y}$ así lo demuestra su influencia en otras alusiones al estilo epistolar, como la Carta 51 de Gregorio de Nacianzo y el tratado

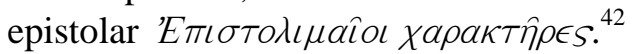

No hay que olvidar tampoco que el propio Filóstrato manifiesta interés por el estilo epistolar, como demuestran sus comentarios en las Vidas de sofistas. ${ }^{43}$ Acerca de Antípatro de Hierápolis, que fue uno de sus maestros, dice Filóstrato que, si bien otros sofistas le superaban en el arte de la declamación y en el de la composición narrativa, sin embargo, en la de cartas nadie era mejor que él: alaba su claridad, la altura de sus opiniones, la adaptación del estilo a las circunstancias y el gusto con que usa el asíndeton, que, sobre todo, confiere esplendor a una carta. ${ }^{44}$ Filóstrato hace referencia, en parte, a la calidad del estilo desde el cargo como secretario ab epistulis graecis que ocupó Antípatro. ${ }^{45}$ Sin embargo, parece que también extiende la

38 Para el texto seguimos la edición de C. L. Kayser de 1871, p. 257 s. (reproducido en A. J. Malherbe, 1988, p. 42), quien no lo publica junto a las Cartas de Filóstrato, pues solía aparecer en las ediciones anteriores precediendo la colección de Cartas; también puede leerse en la edición de R. Hercher, 1871, pp. 14 s., en el apartado que dedica a los tratados sobre epistolografía.

39 Cf. A. Lesky, 1976, pp. 869 ss.; A. R. Benner \& F. H. Fobes, 1962, pp. 387 ss.; en cuanto a su cronología, vid. H. Hunger, 1978, p. 199, quien lo ubica a fines del siglo II (al principio de la llamada «Segunda Sofística»); J. T. Reed, 1997, p. 173, que lo remite al siglo III.

$40 \quad$ VS II 627 s. Sobre ello vid. infra.

41 Vid. H. Koskenniemi, 1956, pp. 29 s.; G. A. Kennedy, 1983, p. 72; A. J. Malherbe, 1988, p. 3.

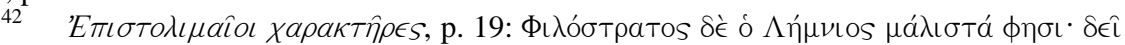

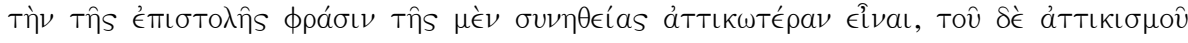

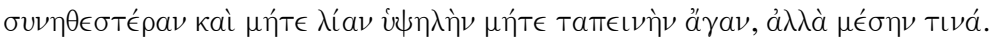

43 VS II 24 y 33.

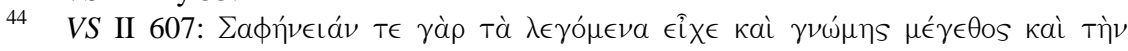

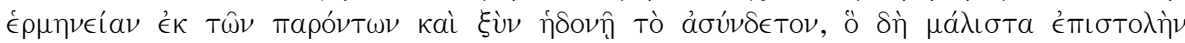
$\lambda a \mu \pi \rho u ́ v \in$.

45 Secretarios utilizados por los emperadores romanos para la escritura de cartas, por lo

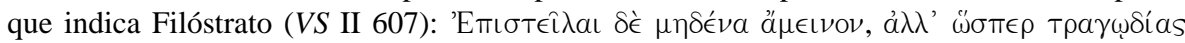


alabanza a su forma de escribir cartas en general y no solo las de carácter oficial. ${ }^{46} \mathrm{Y}$ la ausencia de alguna de estas cualidades en otro secretario $a b$ epistulis es lo que más tarde criticará de Aspasio de Ravena, cuando mencione el escrito que Filóstrato de Lemnos le dedicó, acerca de la composición de cartas: falta de claridad y exceso de controversia, así como incapacidad para adecuar el estilo a las necesidades de un emperador. ${ }^{47}$

En otro nivel del ámbito de la retórica se encuentran los ejercicios preliminares ${ }^{48}$ que se ponían en práctica en las escuelas de retórica ${ }^{49}$ y que se nos han conservado recogidos en una serie de manuales. El primero que conservamos es el de Teón, compuesto en torno al siglo I ${ }^{50}$ si bien su uso en esa etapa formativa parece relativamente antiguo y quizá se remitan a una época tardo-helenística los orígenes de estos manuales. ${ }^{51} \mathrm{El}$ propio manual de Teón ${ }^{52}$ hace referencia a usos anteriores:

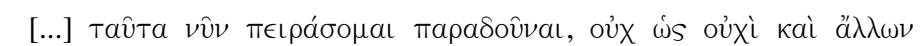

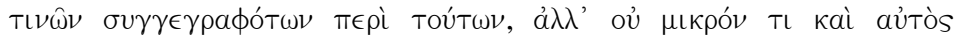

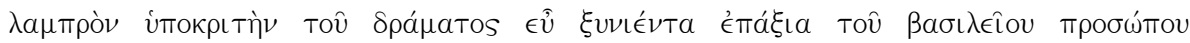
$\phi \theta \epsilon ́ \gamma \xi a \sigma \theta a$.

46 Cf. E. L. Bowie, 2009, p. 26.

47 VS II 628.

48 Vid., sobre los progymnasmata en general, L. Clark, 1957, pp. 175 ss. y 182 ss.; M. L. Clarke, 1971, pp. 36 s.; B. P. Reardon, 1971, pp. 162 ss.; H. Hunger, 1978, pp. 92 ss.; R. F. Hock \& E. N. O’Neil, 1986, pp. 10 ss.; R. Cribiore, 2001, pp. 221 ss.

49 Acerca de las enseñanzas en estas escuelas de retórica y de los distintos niveles que se impartían vid. D. L. Clark, 1957, pp. 59 ss., 64 ss. y 213 ss.; M. L. Clarke, 1971, pp. 38 ss.; B. P. Reardon, 1971, pp. 104 ss.; G. A. Kennedy, 1997, pp. 48 s.; R. Cribiore, 2001, pp. 223 ss. y 231 ss.

50 Entre fines del siglo I y principios del siguiente (vid. G. A. Kennedy, 1972, pp. 615 s., 1983, pp. 54 ss., y 2003, pp. XII s. y 1; E. M. Jenkinson, 1973, pp. 706 s.; o M. Patillon, 1997a, pp. VIII ss.), si bien existen otras propuestas más tardías (vid. M. Heath, 2002-2003, pp. 129 ss.).

51 Así R. F. Hock \& E. N. O’Neil, 1986, pp. 10 y 52. Encontramos comentarios sobre estos ejercicios en Quintiliano y Suetonio (vid. sobre ellos M. Patillon, 1997a, pp. vIII ss.). K. Barwick, 1928, p. 283, apunta sus comienzos en el siglo II a. C. Por otra parte, el término

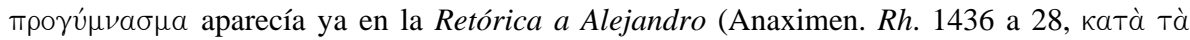
$\pi \rho о \gamma v \mu \nu \alpha ́ \sigma \mu \alpha \tau a)$, pero suele considerarse que lo hace con un significado distinto (vid. S. F. Bonner, 1984, pp. 328 s.) o que consiste en una adición tardía (vid. G. A. Kennedy, 1983, p. $55)$.

52 Las citas corresponden a las páginas y líneas de la edición de L. Spengel, Leipzig 1854, si bien la versión del texto griego procede de la más reciente llevada a cabo por M. Patillon, 1997a, y que conserva esa antigua numeración. El manual de Teón puede leerse también en la edición de G. A. Kennedy, 2003, y J. R. Butts, 1986.

Monografías de Filología Griega 20. ISSN 1136-0860 


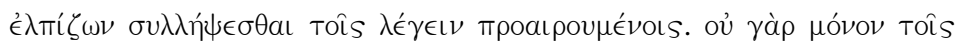

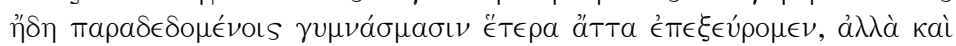

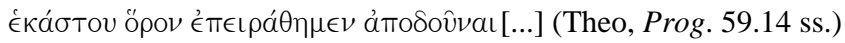

Inevitablemente estas prácticas escolares de alguna manera dejaron huella en la forma final de las obras literarias. De hecho, este primer manual conservado destaca la utilidad de sus ejercicios ${ }^{53}$ para la posterior composición de los distintos géneros:

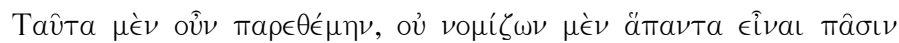

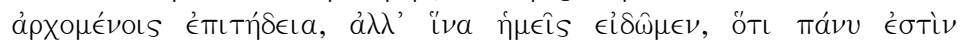

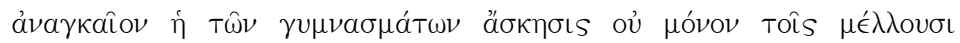

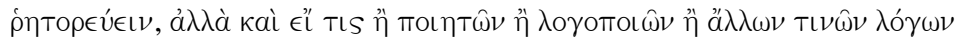

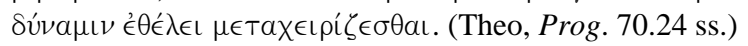

El siguiente manual que nos ha legado la Antigüedad procede probablemente del siglo III, y se ha transmitido dentro del corpus hermogeniano, por lo que suele citarse como los Progymnasmata de Hermógenes. ${ }^{54}$ En la segunda mitad del siglo IV compuso Aftonio, un alumno del sofista Libanio de Antioquía, un nuevo manual que tuvo gran repercusión e influencia, debido, en gran manera, a su sencillez y a los ejemplos que proporciona. ${ }^{55}$ De esta Antigüedad Tardía y de Época Bizantina se conservan numerosas composiciones «progymnasmáticas», entre las que destacan las atribuidas a Libanio. Por último puede distinguirse el tratado de Nicolao de Mira, que en el siglo $\mathrm{V}$ enseñó retórica en Constantinopla. Sus Progymnasmata siguen de cerca los manuales de Teón y Hermógenes, mientras que no parece fijarse en el anterior de Aftonio. ${ }^{56}$

53 Vid. Theo, Prog. 60 ss., donde señala la utilidad general de estos ejercicios y la particular de cada uno de ellos. Además, explica la necesidad de ponerlos en práctica de

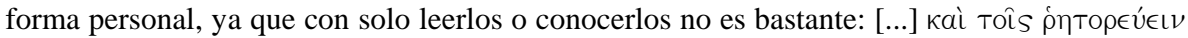

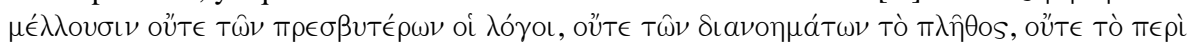

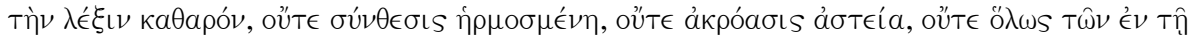

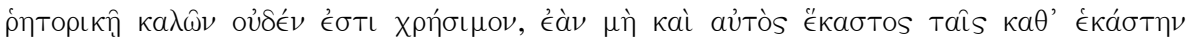

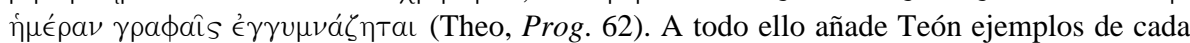
progymnasma que pueden leerse en autores consagrados (Theo, Prog. 66 s.).

54 O Pseudo-Hermógenes; vid. E. Ruiz Yamuza, 1994, pp. 285 ss., y 2000, pp. 293 ss., y M. Patillon, 2008, pp. 165 ss. y 168. Las citas de su manual proceden del número de página y línea de la edición de H. Rabe, 1913. Puede consultarse asimismo la más reciente de M. Patillon, 2008.

55 Vid. H. Hunger, 1978, p. 92; G. A. Kennedy, 1983, pp. 59 ss.; R. F. Hock \& E. N. O’Neil, 1986, p. 11.

56 Vid. G. A. Kennedy, 1983, pp. 66 ss. Seguimos la edición de I. Felten, 1913. 
Además de estos manuales se sabe que existieron otros. Si bien todos ellos recogen una misma tradición anterior, se producen variaciones en el número de ejercicios, en la denominación, en el orden de explicación, en los ejemplos aducidos, etc. Fueron importantes no solo durante la Antigüedad Tardía, sino que en Época Bizantina y hasta el Renacimiento se utilizaron en las escuelas, principalmente a través de diversas traducciones al latín, y, con el tiempo, incluso a través de manuales compuestos en lengua romance siguiendo la estela de los antiguos en griego y latín. ${ }^{57}$

57 Vid. G. A. Kennedy, 1972, pp. 619 ss.; R. F. Hock \& E. N. O’Neil, 1986, p. 11; J.C. Margolin, 1979; L. López Grigera, 1994; L. D. Green \& J. J. Murphy, 2006. 


\section{MAL DE AMORES EN LAS CARTAS ERÓTICAS DE FILÓSTRATO: TEORÍA RETÓRICA Y TEORÍA EPISTOLAR}

Hay, en los escritos de carácter teórico, tres elementos recurrentes que

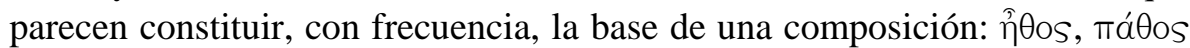

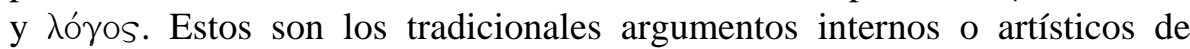

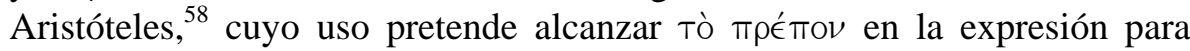
persuadir al público:

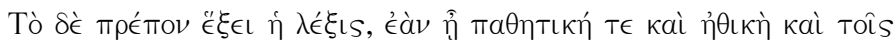

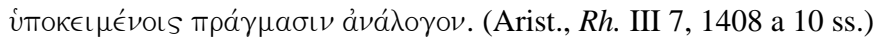

Estos argumentos, además de permanecer en la teoría retórica durante

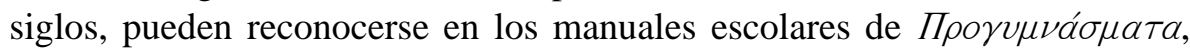
y, asimismo, la preceptiva epistolar mostrará la huella que la retórica ha dejado en ella. ${ }^{59}$ De aquellos nos interesa especialmente el ejercicio escolar de la etopeya. ${ }^{60}$ Este $\pi \rho о \gamma u ́ \mu \nu \alpha \sigma \mu \alpha$, llamado "prosopopeya» por Teón, es útil no solo para la retórica sino también para otros géneros, ${ }^{61}$ y será fundamental en la escritura de cartas, tal y como indica el propio Teón:

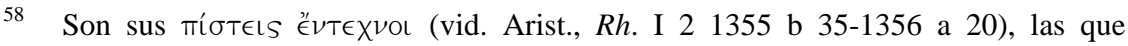
Cicerón nombrará como delectare, movere, docere -vid. Cic., Brut. 185, Orat. 69, De orat. II.189 ss.-; en otros autores: D. H., Lys. 19 (vid. J. Wisse, 1989, pp. 57 s., y 130), Comp. 16.6, 22.4, o Pomp. 3.18; Theo, Prog. p. 72; Anon. Seg. 6 (cf. Arist., EN. II 5 o Rh. II 11) o 94.

59 Vid. E. Suárez de la Torre, 1988, pp. 183 ss., acerca de la influencia de la retórica del siglo IV a. C. en la preceptiva epistolar. Véase también el estudio de esta relación entre teoría retórica y epistolar aplicado a las Cartas de Temístocles en A. Vicente Sánchez, 2006, pp. 372 ss.

60 Sobre los recursos y fuentes de los que parte la composición de etopeyas en la Antigüedad, vid. J. Ureña Bracero, 2005, pp. 93 ss.; y acerca de la relación entre la teoría y las etopeyas literarias vid. C. Heusch, 2005, pp. 11 ss. Sobre otros progymnasmata en la obra de Filóstrato, vid. J. Elsner, 2009, pp. 6 ss.; S. Swain, 2009, p. 40.

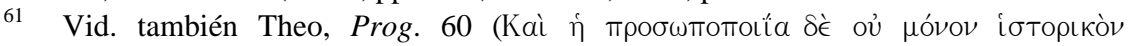

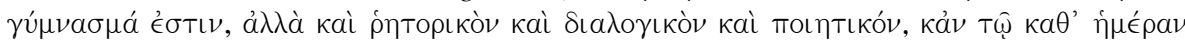




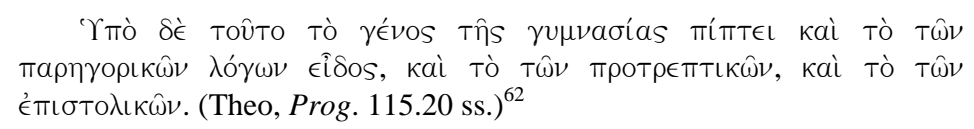

El reflejo de los mencionados argumentos aristotélicos puede rastrearse en estos manuales, que subrayan la capacidad de la etopeya para mostrar

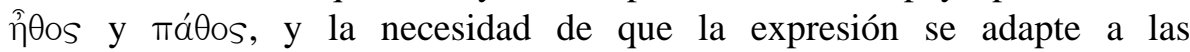
circunstancias; Hermógenes, además, destaca su idoneidad para expresar sufrimiento. Veamos algunas de las referencias más directas que sobre todo ello recogen algunos de los manuales:

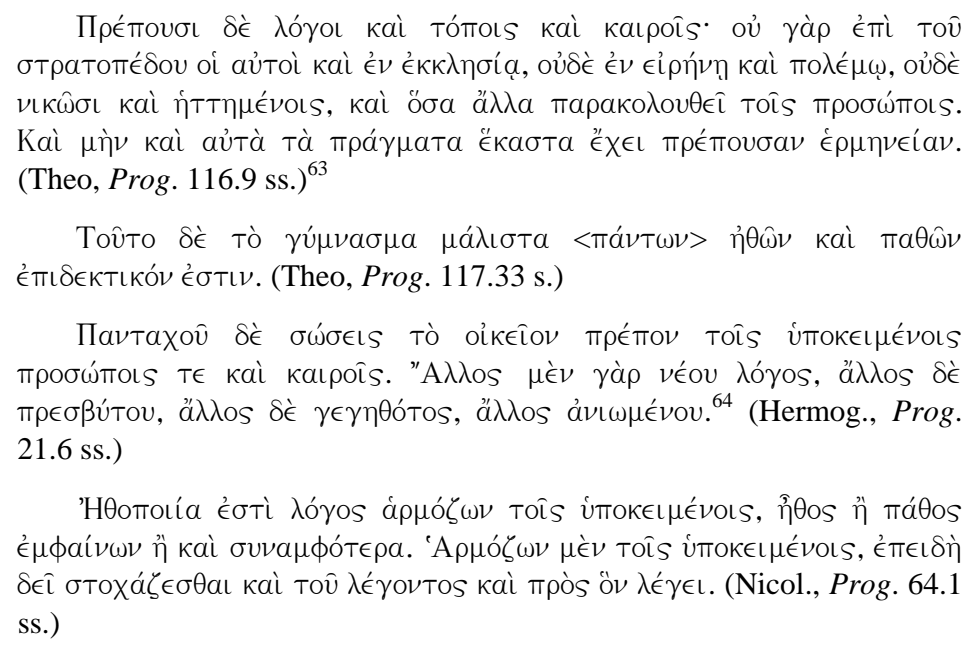

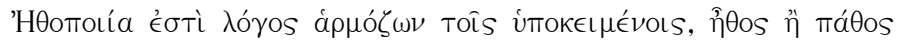

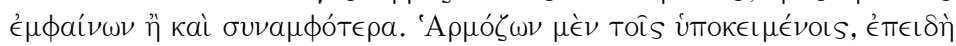

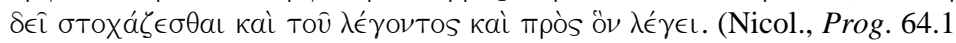
ss.)

Incluido en la instrucción retórica y relacionado estrechamente con este $\pi \rho \gamma_{v} \mu \nu \alpha \sigma \mu \alpha$, se halla el discurso fúnebre, que, por lo general, se dirigía a la pérdida de un ser querido o a alguna ciudad, aunque hay ejemplos de

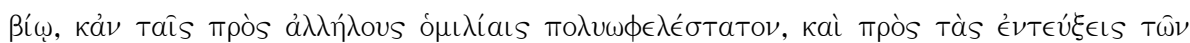

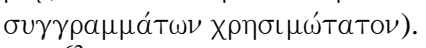

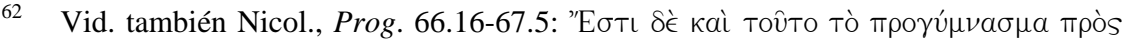

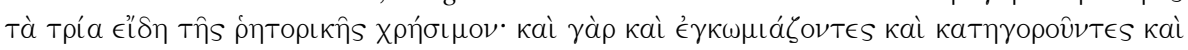

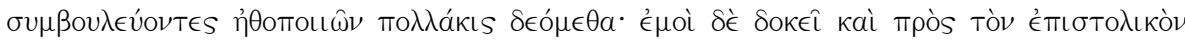

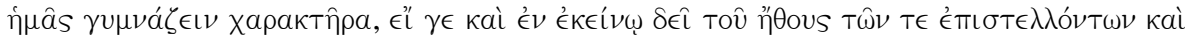

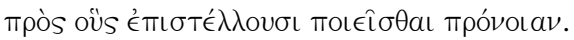

63 Puede leerse, asimismo, Theo, Prog. 116.22 ss., 117.28 ss. acerca de su adaptación a las circunstancias (vid. infra ampliada esta información).

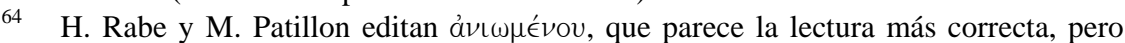

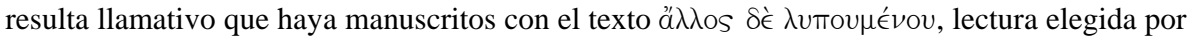
L. Spengel, 1854.

Monografías de Filología Griega 20. ISSN 1136-0860 
lamentos dirigidos a temas diversos. Así, la novela Dafnis y Cloe contiene un lamento por unas flores (IV 8.3-4); y, en el ámbito epistolar, se lamenta Meneclides por la muerte de su amada Báquide (Alciphr. IV 11), ${ }^{65} \mathrm{o}$ el epitafio a los cabellos de un amado en la Carta 16 de Filóstrato (16.8 фépe

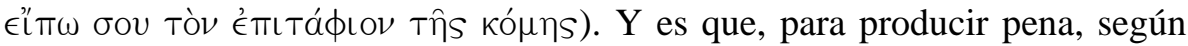
indica Apsines, sirve cualquier tema:

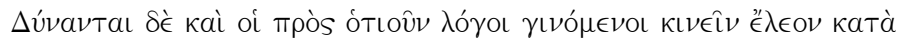

$$
\begin{aligned}
& \text { Tò ímoкє́́ } \mu \in \nu O \nu \text {. (Aps., Rh. 36) }{ }^{66}
\end{aligned}
$$

En opinión de J. Birchall, sería a mediados del siglo I cuando se incluiría la composición de lamentos en las escuelas de retórica, aunque su conexión con la etopeya parece que se desarrolló con posterioridad. ${ }^{67}$

Comenzando por el primero de los argumentos, el $\hat{\eta} \theta$ os, ya Aristóteles ${ }^{68}$ denota su importancia, y, dado que la carta llega a considerarse el espejo del alma, ${ }^{69}$ Demetrio $^{70}$ nos indica que este género ha de mostrar sobremanera los caracteres, ${ }^{71}$ tanto del remitente como del destinatario. ${ }^{72}$

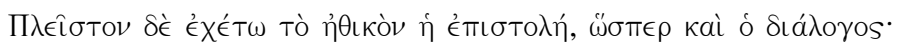

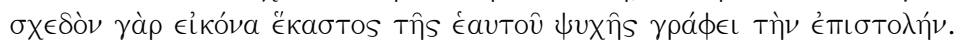

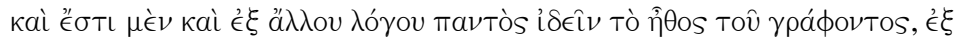

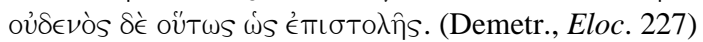

65 Vid. sobre esta Carta A. Vicente Sánchez, 2004.

$66 \mathrm{Y}$, a veces, se utilizan los mismos lugares tanto con personas vivas como muertas, vid. Aps., Rh. 42.

67 J. Birchall, 1996, pp. 3 y 9.

68 Vid. Arist., Rh. II 1, 1377 b 20 ss. y 12-17, 1388 b 31 ss.-1391 b 6, si bien J. Wisse,

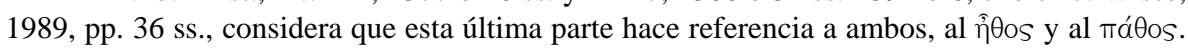
En la retórica de Anaxímenes hay un pasaje que parece mostrar un concepto de ỉĐos similar al que hallamos en Aristóteles (Anaximen., Rh. 14, 8-9, 1431b 10-19), cuando habla de $\dot{\eta}$

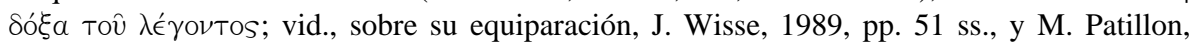
1988, p. 247. Sobre $\hat{\eta} \theta$ os vid. también Hermog., Id. 320.16 ss.

${ }_{69}$ Vid., acerca del topos de la carta como imagen del alma, W. G. Müller, 1980, pp. 138 ss.

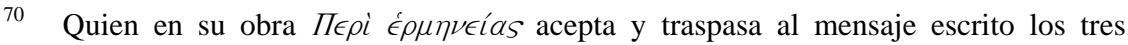
componentes aristotélicos del discurso oral; cf. E. Suárez de la Torre, 1988, pp. 183 ss.

71 Y ello no solo lo defienden así los manuales teóricos, sino que entre los epistológrafos es una idea bastante extendida; vid. cómo se destaca este aspecto en la Carta $a$

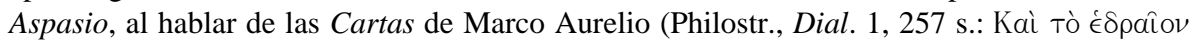

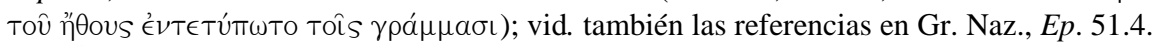

72 Además de adecuar el texto a cada circunstancia particular; vid., sobre ello, Tútro

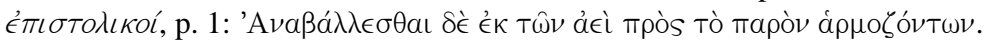



234)

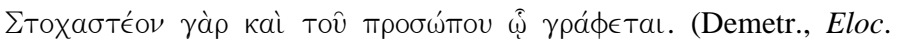

Una perspectiva semejante se propugna para la etopeya, puesto que este ejercicio debe adaptarse a quien lo interpreta y también al destinatario, ${ }^{73} \mathrm{con}$ lo que nuestras epístolas podrían ser ejemplos del tipo de etopeya «doble», tal y como explica Hermógenes, cuando ofrecen rasgos del remitente y del destinatario: ${ }^{74}$

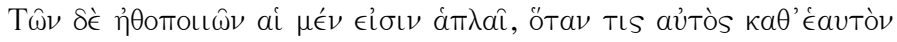

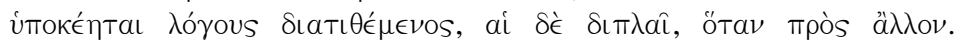
(Hermog., Prog. 20.24-21.5)

La etopeya puede introducir caracteres concretos o indeterminados:

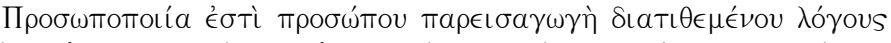

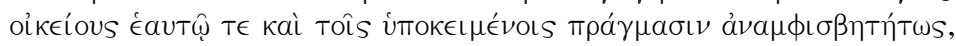

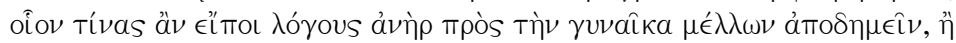

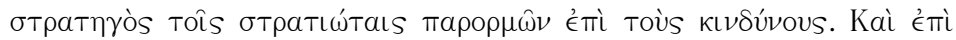

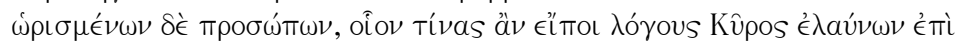

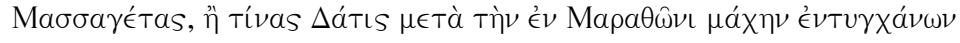
T⿳亠丷厂 $\beta a \sigma i \lambda \in \hat{\imath}$. (Theo, Prog. 115.11 ss.)

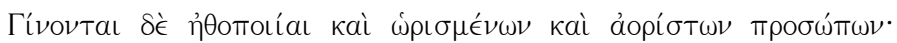

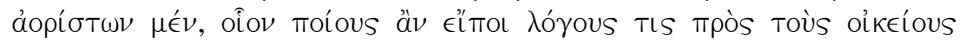

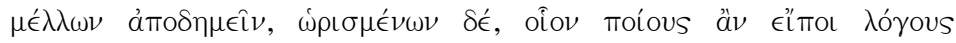

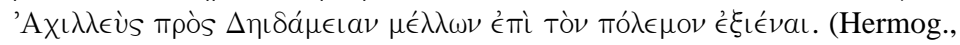
Prog. 20.19 ss.)

Y en las Cartas que expresan lamento son caracteres indeterminados los que encontramos, aunque la colección filostratea contiene también algunos destinatarios definidos. ${ }^{75}$ Por lo tanto, veremos el desarrollo de personajes y situaciones «tipo», similares a los ejemplos de la «progymnasmática»: ${ }^{76}$

73 Theo, Prog. 71.6 s. y 115.23 ss.; o Nicol., Prog. 64.3 ss.; vid. infra sobre la necesidad de que la etopeya refleje las circunstancias.

74 Vid. J. Ureña Bracero, 1993, pp. 267 ss., que juega con la posibilidad de considerarlas etopeyas simples.

75 Vid. las Cartas 40-45, 49, 51, 52 y 65-73. A este respecto, sin embargo, no debe olvidarse el posible múltiple origen de este corpus.

76 Theo, Prog. 115.14 ss.: «¿Qué palabras diría a su esposa un hombre a la hora de irse de viaje?» o «¿Cómo exhortaría un estratego a sus soldados para el combate?»; Hermog., Prog. 20.20 s.: «¿Qué palabras diría a sus familiares alguien a la hora de irse de viaje?». Vid. más ejemplos de etopeyas en los manuales de Aftonio y Nicolao, así como las compuestas por Libanio (pp. 372-434 de la edición de R. Foerster, 1915), por Severo de Alejandría (de quien se conservan las dos últimas atribuidas a Libanio -pp. 434-437 de su edición- y otras 
«¿Qué palabras pronunciaría un amante rechazado por su pobreza?» (Cartas 7 y 23); «¿Cómo expresaría un enamorado el lamento por los cabellos cortados del ser amado?» (Cartas 16 y 61). De esta forma aplica el autor la doctrina no solo a describir caracteres, sino a transmitirlos adaptados a las circunstancias. $^{77}$

Consideramos de contenido erótico-amoroso las Cartas 1 a 41 y 43 a 64; se apartan de esta temática la 42, y de la 65 a la 73. En total, entonces, tenemos un corpus de sesenta y tres epístolas eróticas, de las que se han seleccionado aquí veintiuna en las que la expresión del lamento es el asunto principal.

Pues bien, teniendo en cuenta el tópico que estudiamos, la expresión del lamento o queja que aspira a obtener la benevolencia en ocasiones del destinatario epistolar y siempre del público real, resulta obvio el interés del autor por manifestar el ỉ $\theta$ os, dado que conseguir esa benevolencia es fruto de la capacidad de transmitir la disposición permanente del alma y de conmover suavemente, como ya hemos visto que aconsejaba Aristóteles, ${ }^{78}$ porque a través del î̉ os se produce persuasión:

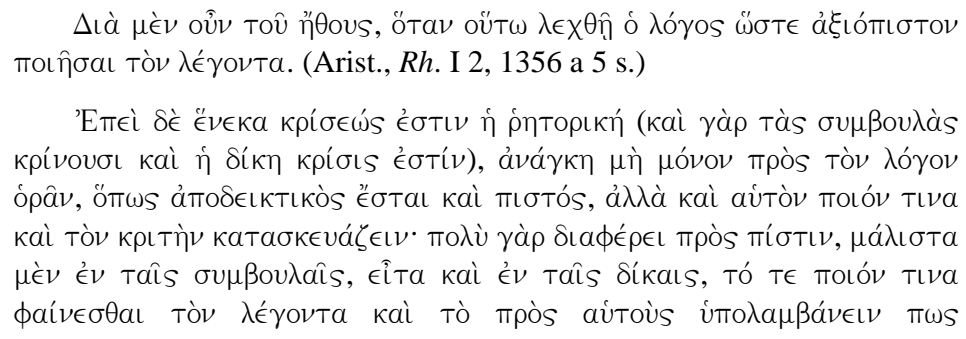

siete recogidas por C. Walz, 1832-1836, pp. 539-548) y otras catorce firmadas por Nicolao, quizás el mismo que compuso un manual de Progymnasmata (pp. 382-394 de la edición de C. Walz, 1832-1836); se conservan colecciones de este tipo hasta finales de época bizantina (cf. H. Hunger, 1978, pp. 92 y 109 ss.). Algunas de estas etopeyas contienen un «lamento de

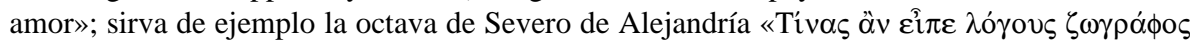

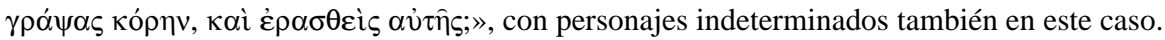

77 Theo, Prog. 115.13 s., 116.9; Hermog., Prog. 21.6 s.

78 Y, asimismo, se aconseja en obras de retórica posteriores; para ello sirva de botón

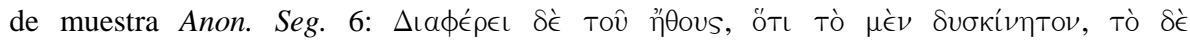

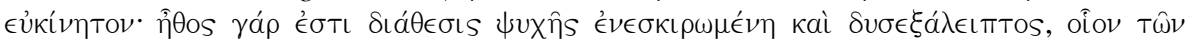

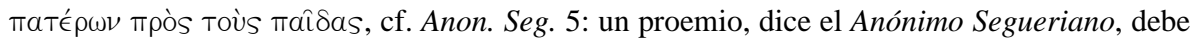

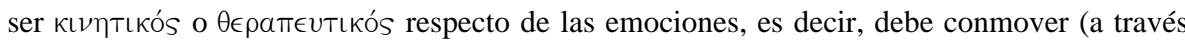

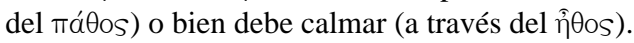




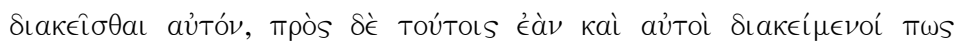

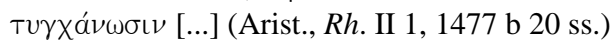
Seg. 94)

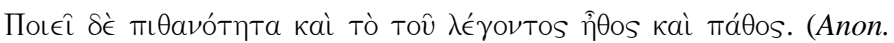

Su efectividad depende en gran medida de una expresión adecuada, ${ }^{79}$ ya que, declara Aristóteles, las palabras poseen un modo de ser, y en ellas se evidencia la manera de pensar y actuar del orador:

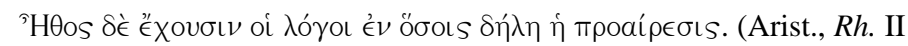
21, 1395 b 13 ss.)

En esa misma línea puede destacarse el comentario de Teón, quien, al explicar las habilidades que los alumnos van a adquirir para componer,

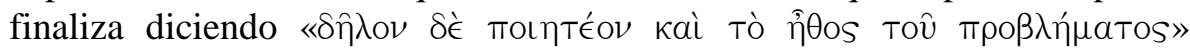
(Theo, Prog. 71.6 s.), que hace referencia, siguiendo la opinión de M. Patillon, ${ }^{80}$ a la actitud que el discurso debe hacer aparecer en quien habla.

Antes de comentar el texto de nuestras Cartas se hace preciso señalar que la impronta de los postulados teóricos sobre las composiciones literarias puede apreciarse en distintos niveles de influencia, teniendo en cuenta, por otra parte, que los propios manuales sugieren hacer uso tan solo de aquellos puntos de la doctrina que convengan en cada ocasión. Así, recomienda Teón,

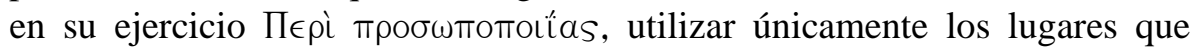
sean adecuados para cada una:

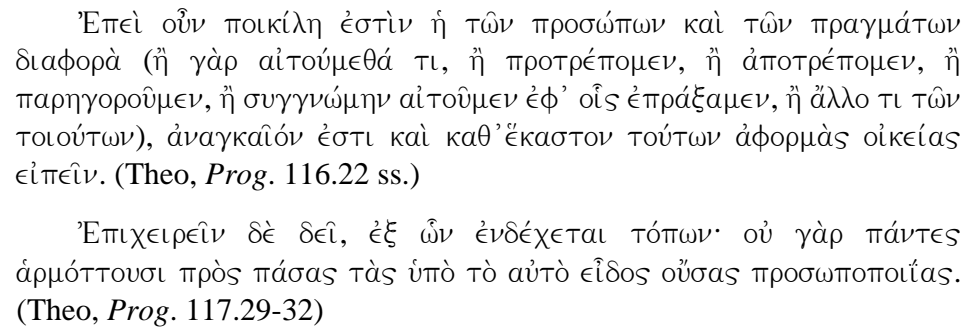

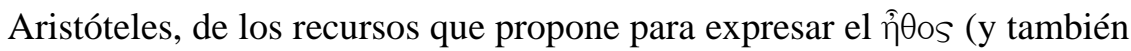

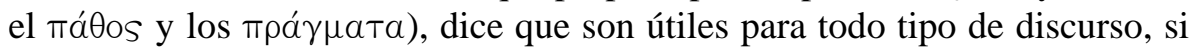
bien deben usarse de forma acertada y no todos a la vez, aunque, en el caso de que uno se exceda, puede recurrir a la «autocensura»:

79 Vid., sobre todo, Arist., Rh. III 7, 1408 a 10 ss., 16 ss., 19 s., 25 ss. y 30 ss.

80 M. Patillon, 1997a, pp. 130 s., nota 107. 


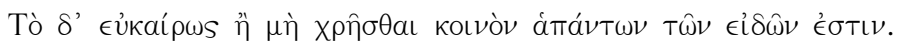

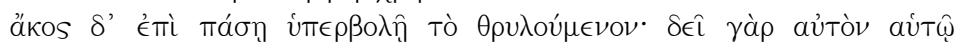

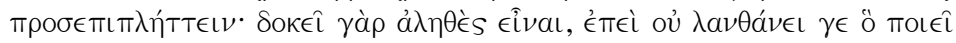

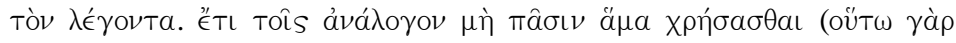

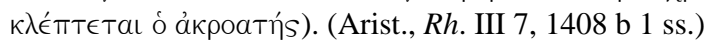

Precisamente el remitente de la Carta 7, tras una larga enumeración de las ventajas del amante pobre frente al rico, se interrumpe con la siguiente pregunta retórica:

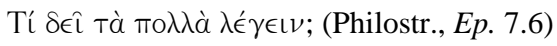

Además, dada la extensión breve de las Cartas, tal y como recomienda la preceptiva epistolar, ${ }^{81}$ es natural que solo puedan recoger alguna de las indicaciones teóricas.

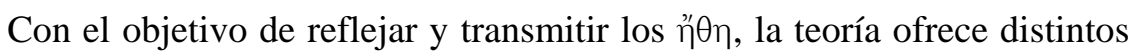
medios. Así, esa necesaria transmisión de los modos de ser, nos dice Aristóteles, depende de la capacidad de mostrar, por una parte, la clase a través de la mención de la edad, sexo y procedencia; y, por otra, la forma de vivir que caracteriza esa clase. Teón, en su progymnasma dedicado a la prosopopeya, añade a éstos otros medios para la transmisión de caracteres: es preciso indicar la suerte, la ocupación y la situación sentimental. ${ }^{82}$

De este modo, algunas de las Cartas que expresan lamento hacen

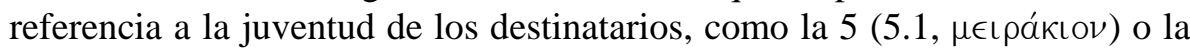

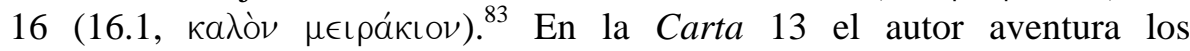
arrepentimientos futuros del destinatario por haber desaprovechado su juventud sin amarse:

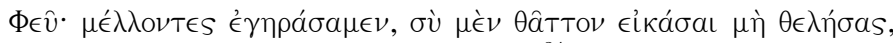

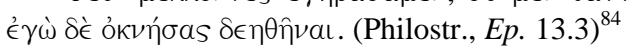

Por ello le incita a disfrutar:

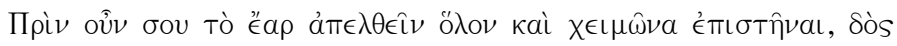

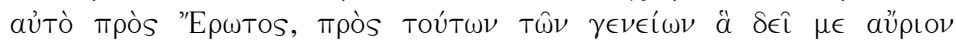
ỏ uvv́vaı. (Philostr., Ep. 13.4)

81 Vid. infra acerca de la brevedad necesaria en el estilo epistolar.

82 Arist., Rh. III 7, 1408 a 27 ss.; Theo, Prog. 115.23-116.14.

83 Es una referencia indirecta al destinatario, comparándolo con un personaje de una

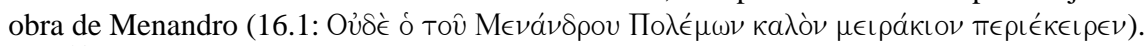

$84 \mathrm{Y}$ al principio de la Carta ya le sugería «anticípate al tiempo, que solo a los

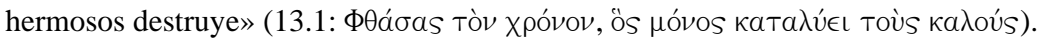


En esta Carta la aparición del vello facial es signo de edad y de

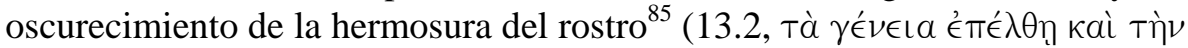

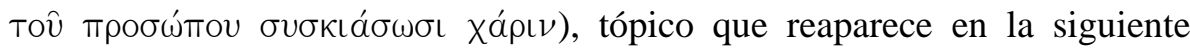
misiva, cuando el remitente augura al destinatario la rápida aparición de barba, que le llevará a suplicar a las puertas de otros (14.2, taxéws $\sigma \epsilon$ $\theta \in a \sigma a i ́ \mu \eta \nu ~ \gamma \in \nu \in \iota \hat{\omega} \nu T \alpha)$. Por otra parte, los encabezamientos de algunos manuscritos utilizan el término $\mu \in \iota$ ракí $\omega$, 'para un joven', como destinatario en las Cartas 5, 7, 11, 13, 14, 16, 24 y $57 .{ }^{86}$

El remitente, ${ }^{87}$ por su parte, en lo que a la edad se refiere, da la impresión en varias Cartas de que es alguien mayor, sobre todo cuando desea a alguno de sus amados que le llegue el momento de hacer guardia en otras puertas (como, al parecer, está haciendo él mismo), o al presumir de su experiencia en viajes y conocimiento de otros países. Otras Cartas, por el contrario, hacen referencia a la efímera juventud de ambos, ${ }^{88}$ y se ajustan a las descripciones de Aristóteles, pues dice de esta edad que es especialmente proclive a los deseos sexuales, los cuales no es capaz de dominar (Arist., $R h$. II 12, 1389 a 3 ss.), como vemos de forma vehemente en muchas de nuestras epístolas. Asimismo le atribuye el Estagirita poco amor por el dinero (Arist., Rh. II 12, 1389 a 13 ss.), puesto que la juventud no ha sentido todavía su necesidad (así lo manifiesta el remitente de las Cartas 7 y 23). Destaca también de los jóvenes que viven con esperanza, la que demuestran sentir respecto de sus enamorados en muchas de las misivas (véase la 7, 23, 28, 29, 24, 57, 26, 13 y 59). Los excesos son propios de esa edad, en el amor y en el odio (Arist., Rh. II 12, 1389 b 2 ss.), evidente en la desproporción e impetuosidad de algunas afirmaciones (por amor ofrece su vida en 5.2, 7.7, 23.247 .6 y 57.2, por despecho desea al destinatario que envejezca y sea rechazado en 14.2, o le augura una mala reputación en 48 ).

85 Este mismo motivo es el tema de la Carta 15, en la que se quiere consolar al amado que sufre por la aparición de vello en sus mejillas.

86 Vid., sobre los destinatarios y los distintos manuscritos, la introducción a la segunda parte de este libro.

87 En opinión de P. A. Rosenmeyer, 2001, pp. 324, 326 y 335 ss., las cartas invitan a imaginar al propio autor Filóstrato como remitente de las mismas, única voz reconocible en la colección (elegida conscientemente por el propio autor, en lugar de reproducir otros personajes de inferior categoría, como habían hecho sus predecesores en el género, Alcifrón y Eliano).

88 Vid. Philostr., Ep. 13.3, donde teme que ambos van a envejecer mientras su amado se decide a aceptarle.

Monografías de Filología Griega 20. ISSN 1136-0860 
En cuanto al sexo de los caracteres, suele presuponerse que el remitente en esta colección es un hombre, y, de hecho, muchas de las Cartas aquí estudiadas así lo desvelan a través del uso del género masculino: en la 6.1,

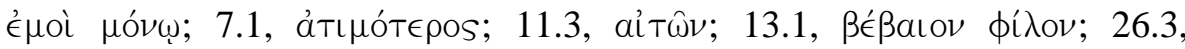

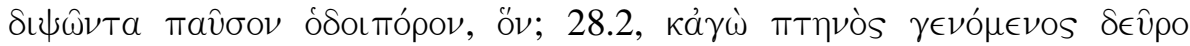

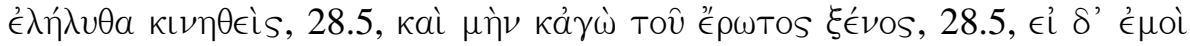

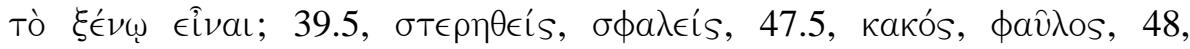

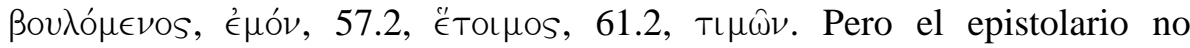
menciona el remitente en las fórmulas de introducción y a veces tampoco el contenido nos lo indica. ${ }^{89}$ Quizá esta ausencia de especificación se deba a que el autor no se preocupó en cubrir esta ficción, bien porque era evidente que las cartas procedían de un hombre (como muchas de las cartas atestiguan), bien porque pertenecían a una colección firmada y el autor se hacía pasar por remitente, o bien debido a que en realidad no interesa esta cuestión al fin con el que se elaboraron las cartas: no importa el remitente cuando lo relevante es el contenido de las cartas y este subordina otras cuestiones formales propias de la ficción epistolar.

En cambio, el destinatario sí que aparece señalado en las fórmulas de introducción de los manuscritos, aunque no siempre estos coinciden. ${ }^{90}$ Como ocurría con el remitente, algunas cartas muestran con claridad el sexo del receptor, mientras que en otras resulta ambiguo. Así, puede afirmarse que las Cartas 7, 11, 13, 48 y 57 son, sin duda alguna, entre hombres; de hombre a mujer la 23, 26, 28, 47 y 61; sin remitente claro para hombre la 5, 14 y 16 , y para mujer la 25, 29 y 59; de hombre para un destinatario no especificado la 6 y 39; en tres cartas, finalmente, no consta el sexo de ninguno de los dos, en la 12, 24 y 50, si bien en la 24, la comparación con Agamenón y su belleza parece indicar un destinatario masculino, y en la 50 se confronta con Caribdis lo que parece un receptor femenino. ${ }^{91}$ Sin embargo hay un hecho que puede aclarar sustancialmente este asunto y que además nos hace pensar en las composiciones escolares: cada temática ${ }^{92}$ aparece desarrollada en cartas con sendos destinatarios ${ }^{93}$ masculinos y femeninos ${ }^{94}$. De este modo,

89 Así, de las Cartas que expresan lamento, la 5, 11, 12, 14, 16, 24, 25, 29, 50 y 59.

$90 \quad$ Vid., sobre ello, S. Follet, 1997, pp. 135 ss.

91 Comparación que se encuentra ya en otros autores, como Horacio, Oda I 27.

92 Si bien hay tópicos repetidos en varias Cartas. Acerca de los motivos y temas principales en las Cartas de Filóstrato, vid. E. Suárez de la Torre, 1991, pp. 115 ss.

93 Tan solo la Carta 6 quedaría sin pareja según esta distribución. 
como la 11 va dirigida, sin lugar a dudas, a un hombre, podemos determinar con mayor seguridad que su correlativa 50 se destina a una mujer; aunque la 12 no nos lo especifica claramente, la 10, tanto por su encabezamiento en los manuscritos como por su contenido, va dirigida a un hombre, por lo que la 12 será para mujer; respecto de la 24, además de la comparación con la belleza de Agamenón, tenemos su versión femenina en la 25; la Carta 64 se destina en unos manuscritos a una mujer y en otros a un joven, pero el texto corrobora esta última opción, ${ }^{95}$ y su compañera, la Carta 39, a pesar de no decantarse su contenido por un sexo u otro, en todos los manuscritos que escriben el encabezamiento aparece dirigida a una mujer. ${ }^{96}$

Otro medio para favorecer la transmisión del $\hat{\eta} \theta 0 \mathrm{~s}$ es indicar la procedencia de los personajes, que aparece tratada en uno de estos pares, pues las Cartas 5 y 47 se preguntan acerca del origen del destinatario y de su crueldad $;{ }^{97}$ la 28 lamenta el rechazo a causa de su procedencia extranjera y constituye un alegato a favor del amante foráneo y en detrimento del patrio; ${ }^{98}$ el remitente de la 39 hace de su exilio un argumento lícito en sus requerimientos hacia la amada. ${ }^{99}$

94 Así, entre las Cartas que presentan lamento, tenemos la misma versión con destinatario masculino en la Carta 5 y femenino en la 47: el remitente, rechazado por los destinatarios, se pregunta acerca de su procedencia dada su crueldad y acaba ofreciéndoles su vida; quejas por haber sido despreciado debido a su pobreza encontramos en las Cartas 7 , para un chico, y 23, para una chica; lamento por los cabellos rapados de los amados en las Cartas 16 y 61; enfado que afea a los amados en 24 y 25, etc.

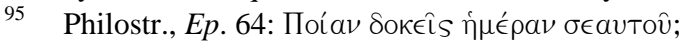

96 Vid. infra la Tabla I que sigue a la introducción en la selección de Cartas.

97 A lo largo de la Carta 5 va descartando las diferentes procedencias del joven que le

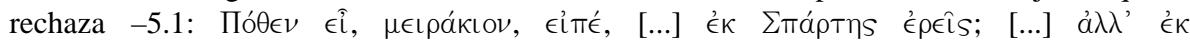
$\Theta \in \sigma \sigma a \lambda i ́ a s ;[. .] ~ a. ̉ \lambda \lambda \grave{a}$ 'A $\theta \eta ́ n \eta \theta \in \nu$;- para terminar exclamando que debe de ser escita, dado su

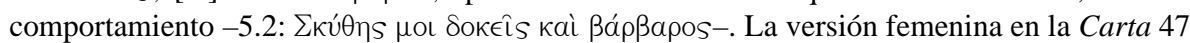

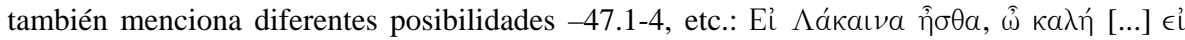

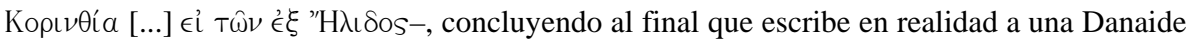

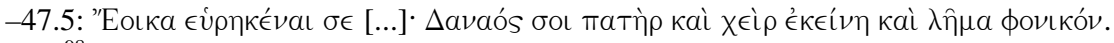

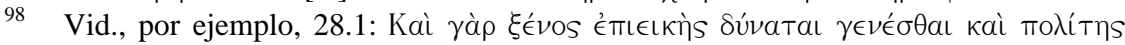

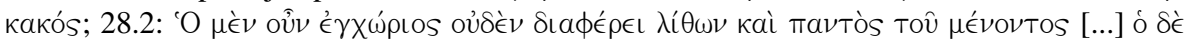

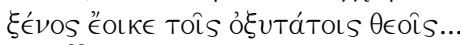

$99 \mathrm{Y}$, de hecho, ese es el tema en torno al cual gira toda la Carta; vid., a modo de

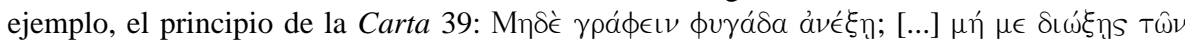

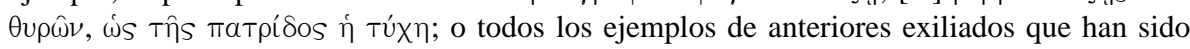

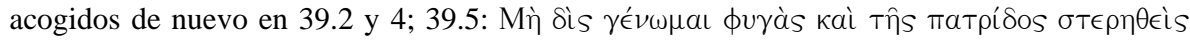

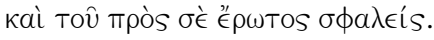


La suerte y forma de vida de nuestros personajes constituye el tópico desarrollado especialmente en la pareja de Cartas 7 y 23, donde el enamorado pobre se defiende frente al rico: consiste la Carta 7 en la exposición de los rasgos que caracterizan al pobre y sus actos, confrontado todo ello con la actitud y valores del rico; el pobre remitente de la 23 destaca sus recursos, de los que, a su vez, carece el rico. ${ }^{100}$ La descripción de los ricos en estas Cartas coincide con la de Aristóteles (Arist., Rh. II 16, 1390 b

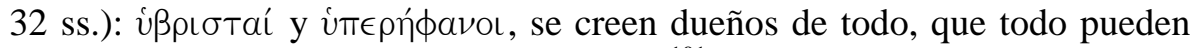
comprarlo y disfrutan con la ostentación. ${ }^{101}$ En la Carta 23 se expone lo propio de la mujer cortesana, por una parte, y, por otra, de la libre: de la primera lo es exigir un pago; y otorgar sus favores al que lo merece de la segunda, que es el caso de la destinataria en cuestión. Otros tipos de vida, la del extranjero y la del exiliado, aparecen definidos en las Cartas 28 y 39, como ya se ha comentado en el párrafo anterior.

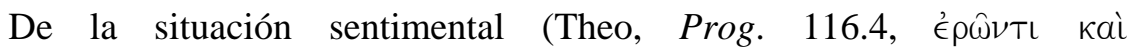
$\sigma \omega \phi \rho \circ \nu$ ov̂ $T$ ) en general podemos apreciar a lo largo del corpus los modos y maneras de aquellos afectados por el amor, y, respecto del tópico aquí tratado, de aquellos a los que este sentimiento hace sufrir y también de las diferentes respuestas que reciben por parte de los objetos de su amor: sirvan de muestra la descripción del enamorado que nos proporciona el canto a sus ojos, ${ }^{102}$ culpables de su sufrimiento, que supone la Carta $12 ;{ }^{103}$ el amante despechado que recrimina, injuria, aoja e incluso amenaza a su amado en la $14 ;^{104}$ el enamorado que expone sus pretensiones y cuitas y considera al

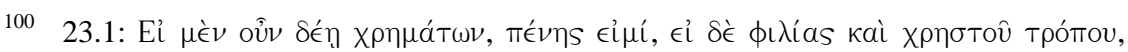

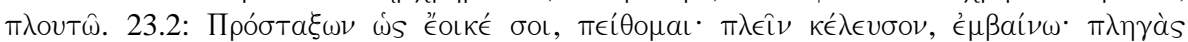

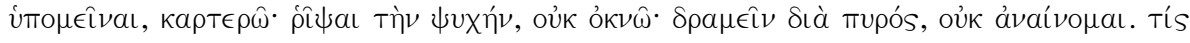

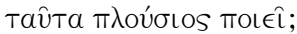

101 Vid., especialmente, cómo trata al ser amado un enamorado pobre y cómo un rico en 7.4-5, que aparece después personalizado ya en remitente y destinatario, en 7.6: 'O

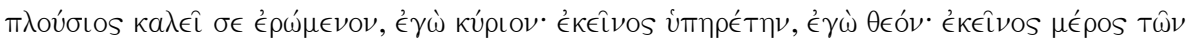

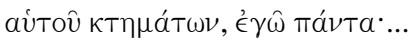

102 Sobre la relación el amor y el acto de ver en la Antigüedad, vid. A. Walker, 1992, pp. 132 ss.

103 Puesto que el amor penetra a través de los ojos, son ellos los protagonistas de la Carta 12, los responsables y los que van a sufrir las consecuencias; vid., por ejemplo, 12.3:

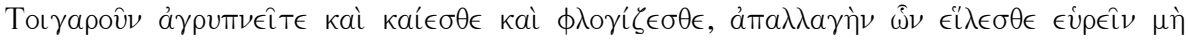
$\delta v \nu a ́ \mu \in \nu o$. De las que expresan lamento otras Cartas que proyectan su situación sentimental sobre los ojos son la 11, 50, 29 y 59.

104 Del mismo tono de crítica y censura son la 6 y la 48. 
objeto de su querencia la cura de sus males en la $29 ;{ }^{105}$ la petición de que se pase un enfado, etc. Y de los destinatarios tampoco es raro que se proporcione su situación sentimental, al menos respecto del interesado: suele ser de abandono, rechazo, enfado o ignorancia, como es natural en la temática que se ha seleccionado. En suma, puede decirse que todos están enamorados, hasta los que solo manifiestan enfado y queja, puesto que todo ello está provocado por el amor que todavía sienten.

Así pues, en estas composiciones que pertenecen al género epistolar se

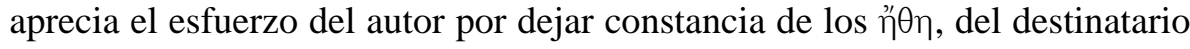
y del remitente, de la misma manera que Aristóteles consideraba necesario hacer cuanto antes:

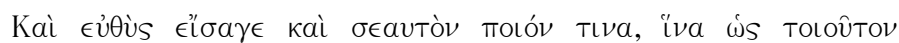

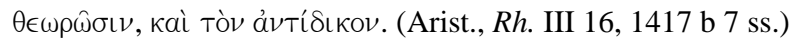

Y, de este modo, en ocasiones no solo son remitente y destinatario los caracteres descritos, sino que también se evidencia el del rival en amores, como hacen de forma especial las Cartas 7 y 23 (el rival rico), y 28 (el rival autóctono).

Como ya se ha visto, la teoría señala la importancia de adecuar la expresión a los personajes, pero también debe adaptarse al tema y a las circunstancias: ${ }^{106}$

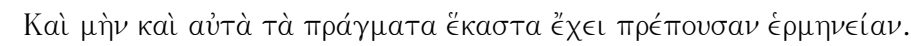
(Theo, Prog. 116.12 ss.)

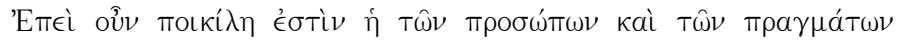

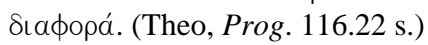

Hermógenes dedica en su $\Pi \epsilon \rho i$ i $\delta \epsilon ́ \omega \nu$ un capítulo al $\hat{\eta} \theta$ os, en el que analiza los distintos elementos que ayudan a transmitir los caracteres:

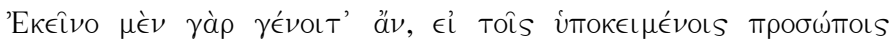

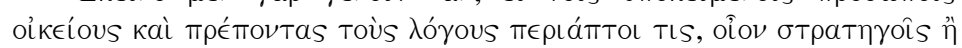

105 Similar en 13, 26, 57, 28 y 39.

106 Arist., $R h$. III 7, 1408 a 10 ss. (vid. supra). En el apartado dedicado al estilo en este trabajo se hace referencia a esos elementos que producen $\hat{\eta} \theta$ os en el discurso, como la moderación, la sencillez, la impresión de sinceridad y la espontaneidad y, en menor medida,

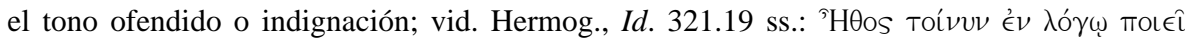

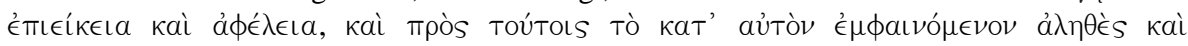

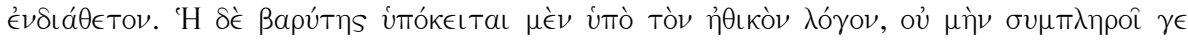

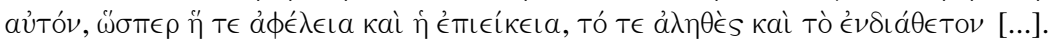




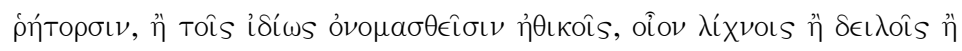

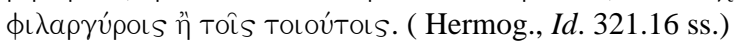

Para ello Aristóteles recomienda manifestar la intención del discurso, al que, de no resultar creíble, puede agregarse entonces el motivo de su composición:

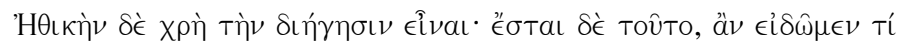

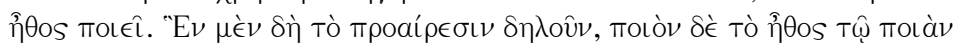

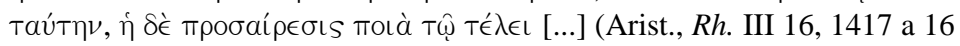
Ss.)

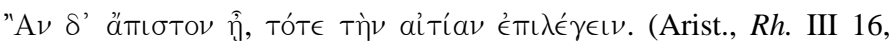
1417 a 28 s.)

Dado que el tema aquí analizado es el lamento, es natural que la exposición del sufrimiento sea el determinante que impulsa la escritura de cada Carta. Ese sufrimiento está inspirado por motivos variados: la pobreza del remitente en la 7 y la 23; el amor como asedio constante que ha ganado su fortaleza a través de los ojos en la 11, la 50 y la 12; el interés y pasión que se ha despertado en el remitente hacia el destinatario en la 13, 26, 57, 28, 29, 39 y 59; reproches (de mayor o menor intensidad) provocados probablemente por un abandono en la 5, 47, 6, 14 y 48; los cabellos cortados del ser amado en la 16 y la 61; un enfado de los destinatarios en la 24 y 25. En cuanto a la intención de las Cartas, la mayor parte de ellas se preocupa de mencionarla, especialmente hacia el final de la misiva: la 5 y la 47 ofrecen la propia vida con tal de tener cerca al objeto de su devoción (5.3, 47.6); la 7 y la 23 tienen como propósito mostrar a los destinatarios sus verdaderas riquezas (7.6-7 y 23.2); mientras, la 11 pretende del amado que calme su sed porque se quema de amor (11.3), la 50 y la 12 simplemente presentan la exposición de la causa de su malestar; las Cartas 13, 26, 57, 28, 29, 39 y 59 quieren todas conseguir que la persona elegida acceda a sus pretensiones. $^{107}$

Y también en relación con la expresión del $\hat{\eta} \theta$ os recomienda Aristóteles manifestar con claridad las emociones, ${ }^{108}$ como vemos que hacen las Cartas:

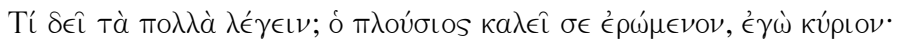

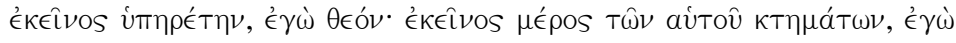

107 Y así manifiestan directamente sus peticiones: 13.1 y 4; 26.3; 57.2; 28.3, 4 y 5; 29.4; 39.1 y 5; o se pronuncian dispuestos a todo: 59.4; 5.2 y 47.6 (la propia vida).

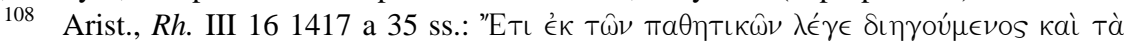

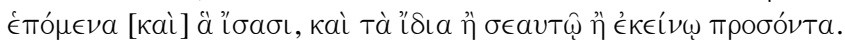




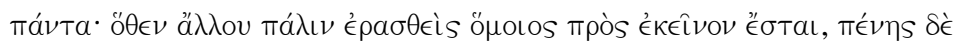

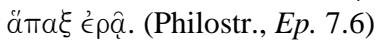

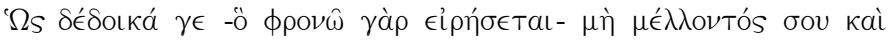

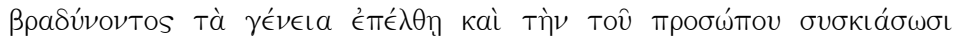

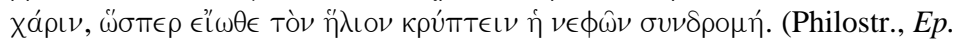
13.2)

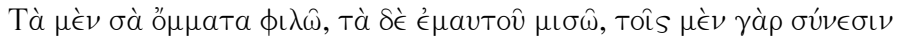

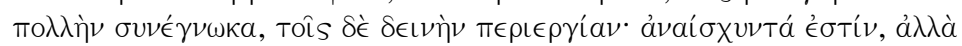

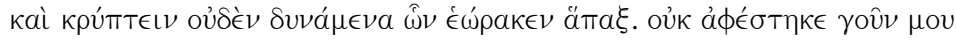

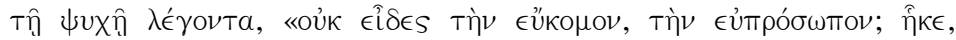

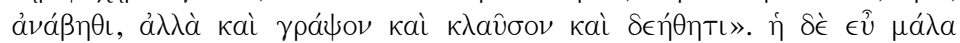

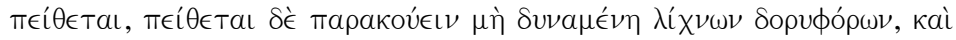

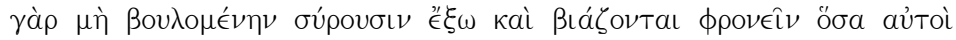

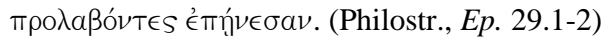

Los manuales escolares estipulan tres clases de etopeyas en función del predominio de la descripción de los caracteres, por un lado, y, por otro, de las emociones, siendo el tercer tipo resultado de la mezcla de los anteriores:

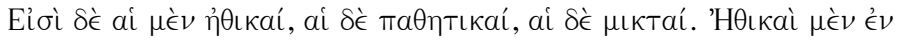

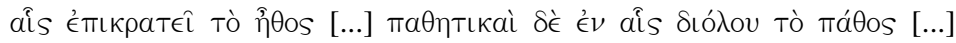

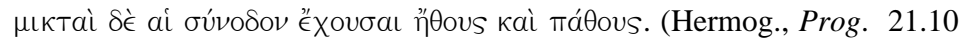
SS.) $)^{109}$

Hasta este punto se ha estudiado cómo nuestras Cartas bien podrían clasificarse dentro del primer tipo, ì $\theta$ เкá, pero a continuación se va a desarrollar el segundo aspecto, el emotivo, de modo que podríamos clasificar estos documentos epistolares como «etopeyas mixtas».

Mediante el má $\theta$ os se expresan sentimientos y se conmueve al público de una manera temporal, por lo que debe destacarse su relevancia y función en una composición literaria. El objetivo de la retórica es persuadir de algo, ${ }^{110} \mathrm{y}$ sobre esto puede influir la capacidad de hacer sentir una emoción u otra, ${ }^{111}$ de suerte que resulte más o menos convincente:

109 Vid. Aphth., Prog., 34 s.; Nicol., Prog. 64.

110 Al igual que la epistolografía, cf. E. Suárez de la Torre, 1988, pp. $181 \mathrm{s.}$

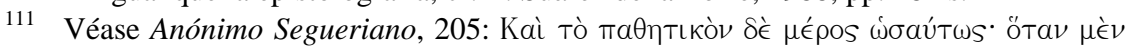

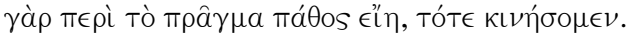




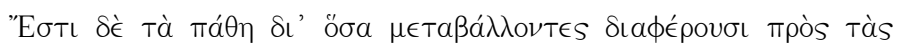

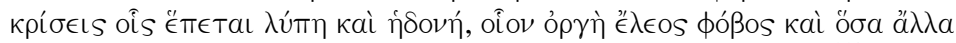
тolav̂Ta, кaì tà Toútols évavtía. (Arist., Rh. II 1, 1378 a 19 ss.) $)^{112}$

Así pues, para resultar creíble y digno de confianza es esencial la impresión que se causa sobre el auditorio, cuestión esta en la que entran en juego los sentimientos ya mencionados, como la ira, la compasión o el miedo, que producen placer y dolor, sensaciones que influyen en el ánimo del público. ${ }^{113}$ Según Aristóteles es preciso conocer el comportamiento provocado por la emoción, a quién se dirige y por qué motivos; ${ }^{114}$ del elenco de emociones que este autor trata están relacionadas con la expresión del lamento el amor y la amistad y la compasión ( $\phi \iota \lambda i ́ a$ y $€$ É $\lambda \in O S$ ) especialmente sobre el destinatario si este es el causante de la pena, pero, además, sobre terceros destinatarios y el público general puede despertarse cólera, enemistad, odio, miedo, indignación, envidia o desprecio. ${ }^{115}$ A Aristóteles y Anaxímenes debemos la teoría clásica que ha seguido vigente y ha influido sobre la retórica y sobre la literatura posterior. Más cercanos a la época de Filóstrato pueden destacarse dos tratados de retórica que dedican especial atención a la creación de rá日os: el llamado Anónimo Segueriano, que expone cuatro principales $\pi a ́ \theta \eta$, relacionados igualmente con la expresión

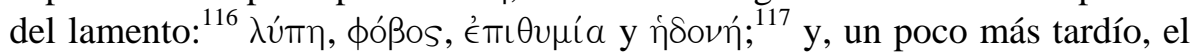
de Apsines de Gádara, ${ }^{118}$ interesante sobre todo por sus dos apartados del

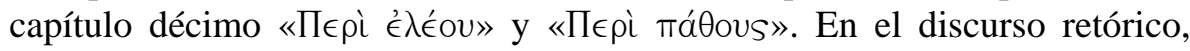
una vez aseguradas las simpatías del auditorio a través del buen carácter del hablante, debían despertarse las emociones sobre todo en el epílogo, por lo

112 Vid. también Anon. Seg. 94 sobre convencer y resultar convincente además de

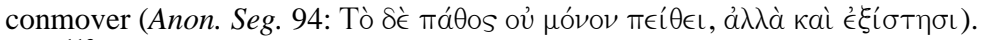

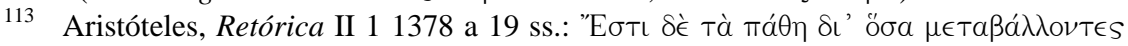

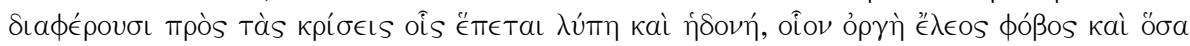

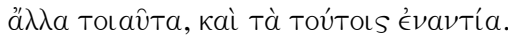

114 En Arist., Rh. II 1, 1378 a 22 ss., nos lo ejemplifica con la ira, y, a continuación, con

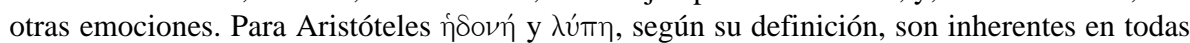
las emociones (J. Wisse, 1989, pp. 288 y 67).

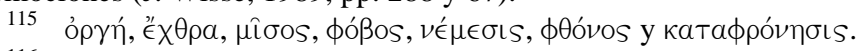

116 Con ellos, señala el autor, puede crearse ỏ $\rho \gamma \eta ́$ y $\pi \in \iota \theta \hat{~}$ (Anon. Seg. 231).

117 Anon. Seg. 224.

118 Sobre el má $\theta$ os Apsines reconoce su importancia en la tragedia, pero asimismo destaca su uso en otros ámbitos como la oratoria cuando se trata de una ciudad o una persona que ha sufrido alguna desgracia que no merecía; vid. Aps., $R h$. 48, e igualmente Arist., $R h$. II 8, 1386 b 5 ss. Vid. infra acerca del desarrollo de esta cuestión. 
que las indicaciones de los manuales generalmente aparecen en las explicaciones relativas a esa parte del discurso. ${ }^{119}$

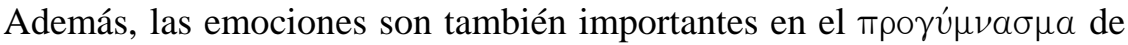
la etopeya, ${ }^{120}$ que debe conmover o agradar al público:

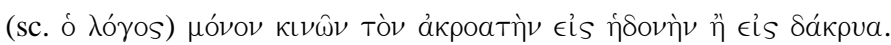

(Nicol., Prog. 67.13 s.)

Así las cosas, puede afirmarse que cumplirían nuestras Cartas con las indicaciones del manual de Nicolao de Mira, a saber, deleitar al público gracias a la belleza de la composición, a la diversión y entretenimiento que proporciona, por una parte, y por otra, conmoverlo con su expresión del lamento. Y, aunque pueda parecer contradictorio que se disfrute de la expresión de una queja o lamento, nos explica Aristóteles que no es necesario que el objeto imitado sea placentero, puesto que es la calidad de la imitación lo que provoca el placer. ${ }^{121}$

Un rápido vistazo a las Cartas permite observar fácilmente cómo gustaba el autor de realizar comparaciones con otra persona o cosa, algo que tanto el Anónimo Segueriano como Apsines recogen entre sus recursos que generan

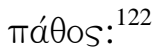

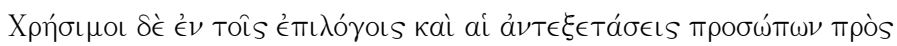

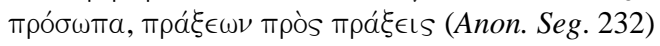

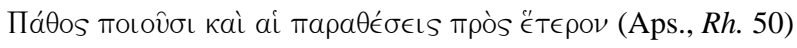

Evidentemente la totalidad el corpus de cartas eróticas tendrá entre sus objetivos despertar las emociones del destinatario y del público; si bien pueden encontrarse comparaciones de este tipo también en el resto del

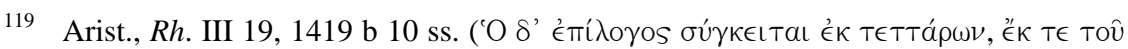

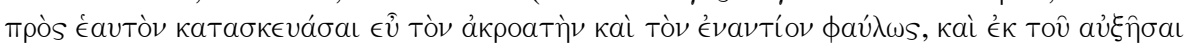

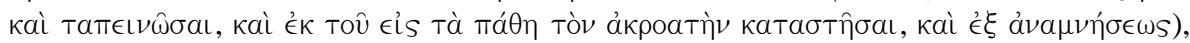

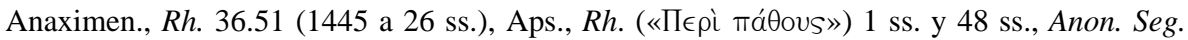
228, 237-238 y 243.

120 Vid. J. Ureña Bracero, 1999, pp. 333 s., acerca de la influencia del má日os sobre los demás recursos en la práctica de las etopeyas y en su preceptiva retórica.

121 Arist. Rh. 1369 b 33 ss., 1371 b 5 ss. Vid. infra acerca de los temas propios del estilo epistolar.

122 Acerca del uso de comparaciones con el pasado, vid. infra.

Monografías de Filología Griega 20. ISSN 1136-0860 
corpus de las cartas eróticas, ${ }^{123}$ no son, en cualquier caso, tan frecuentes como en las que presentan el tópico del lamento de amor. Algunas de las Cartas presentan largas enumeraciones con las que se contrasta algún aspecto del lamento, como las Cartas 5 y 47, que mencionan distintas procedencias; la Carta 7 es casi toda ella una sucesión de comparaciones con divinidades, personajes históricos, objetos y una ventajosa confrontación entre el pobre y el rico; la Carta 16 también es rica en sus términos de comparación, pues incluye poetas, elementos de la naturaleza, soldados bárbaros y griegos, objetos, ciudades, hombres y divinidades; la 28 en sí misma pretende cotejar al nativo con el extranjero y para ello se sirve igualmente de innumerables aspectos; la 39 compara al exiliado con personajes históricos, elementos de la naturaleza, dioses y a su propio exilio de la patria con el del amor. En la parte que no expresa lamento un número doble de Cartas nos presenta, sin embargo, tan solo cinco con este tipo de enumeraciones: Cartas 8, 18, 27, 35 y 38, esto es, aproximadamente en la mitad de las ocasiones (dado que el número de Cartas que no expresan lamento dobla al de las aquí estudiadas). Sin formar estas largas secuencias también hay un buen número de Cartas que abundan en comparaciones, como la 12.1 (dos comparaciones independientes con varios miembros); 13.1 (tres), 13.2; 23.1 (tres), 24.1 (tres); 25.2 (cinco), 25.4; 50.1, 50.2; 57.1 (cuatro), 57.2; 61.1, 61.2. En este sentido encontramos un número similar de Cartas entre aquellas ajenas a este estudio (Carta 1, 4, 10, 15, 19, 22, 30, 32 y 60) sin olvidar que estas doblan en número a las nuestras. Más parcas en cuanto a los símiles, pero todavía con algún ejemplo, como es natural que aparezca este recurso en un producto literario, son las Cartas 11.1 (dos), 14.1, 26.2, 48 y 59.1; y, con ese mismo uso moderado, aparecen comparaciones de forma regular en la otra serie (Carta 3, 9, 17, 20, 21, 31, 33, 34, 36, 37, 43, 44, 45, 46, 51, 53, 54, 55, 56, 58 y 62). Finalmente, tenemos dos Cartas donde no se produce ningún contraste con persona, cosa o cualquier otro elemento, la 6 y la 29, frente a las siete del otro grupo de Cartas, la 2, 40, 41, 49, 52, 63 y 64. Por lo tanto, puede afirmarse que es muy frecuente el uso de contrastes para expresar de forma vehemente la emoción, y se observa una especial reiteración cuando esa emoción es el sufrimiento, mientras que en las Cartas que manifiestan otros tipos de

123 Recordemos que la colección consta de sesenta y tres epístolas de contenido eróticoamoroso, de las que se han seleccionado veintiuna cuyo tema principal es la expresión del lamento. 
sentimientos se recurre a este elemento, pero, como se ha visto, en menor medida.

Asimismo transmiten emoción las hipérboles, que Apsines precisa pueden ser ilimitadas:

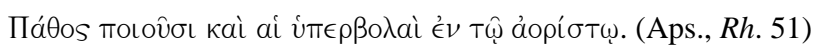

Y Aristóteles disculpaba las exageraciones fruto de la emoción:

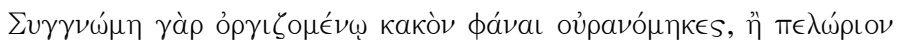

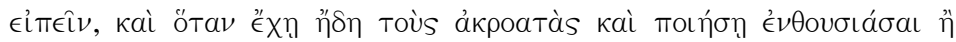

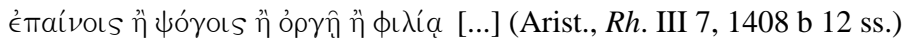

Sobre ellas decía el Estagirita que son una muestra de impetuosidad,

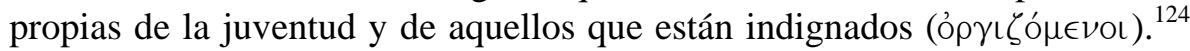
Y así vemos que no es raro que el remitente, en su desdicha amorosa, se ofrezca a sufrir cualquier tipo de mal (heridas en 5.2 y 23.2), incluso la muerte (7.7, 23.2, 47.6 y 57.2); considere al ser amado lo más importante por encima de todo; sienta su amor como un fuego inextinguible, tanto que sería capaz de incendiar el agua (11.3); solicite los amores de un muchacho al que insta a acceder puesto que mientras duda ya ha envejecido (13.3); llame «homicida de tu cabeza» (16.1) al que ha rapado sus cabellos y le anuncia un epitafio digno de ellos (16.8); con la misma temática considera que su amada, al perder su cabellera, ha sufrido los horrores de la guerra (61.2); para sus males solo ella es el remedio (29.4), por el que le ofrece versos inmortales y un recuerdo imperecedero (29.4); y, un tanto despechado, tacha a su amada de ser peor que Caribdis (50.2).

Especialmente apropiadas para la expresión de las emociones resultan las aporías y preguntas retóricas: ${ }^{125}$ Rh. 53)

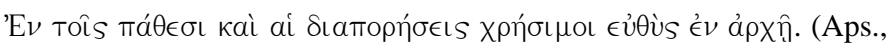

De ellas nuestras Cartas hacen un buen uso, dado su elevado número: 5.1 (nueve); 47.2 (cuatro), 47.4; 6 (dos); 7.6, 7.7 (cinco); 23.2; 11.1, 11.3;

124 Arist., $R h$. III 11, 1413 a 30 ss. Y en el tratado Sobre lo sublime se previene acerca de los excesos en su uso, ya que pueden provocar un efecto no deseado (Longin. 38).

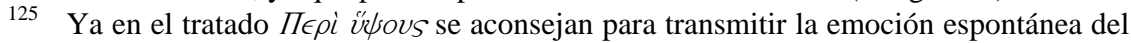
orador, puesto que conferían grandeza y convicción a la expresión, vid. Longin. 18.1-2. De acuerdo con la espontaneidad que transmiten a la expresión las preguntas está Hermógenes (Hermog., Id. 360.13 ss.), especialmente cuando se combinan con la invocación, como en 5.1 o 61.1 .

Monografías de Filología Griega 20. ISSN 1136-0860 
50.1 (dos); 12.1 (dos), 12.3; 13.3; 16.2 (dos), 16.3; 61.1; 24.2; 26.1; 57.1 (cuatro), 57.2; 28.4, 28.6; 29.1; 39.1; 59.1 (tres), 59.2, 59.3, 59.4. Además, algunas de las Cartas comienzan directamente con una pregunta (Cartas 5, 11, 12, 39, 50 y 61), tal y como aconsejaba Apsines para reforzar su efecto, si bien alguna de las Cartas no contienen este recurso (14, 25 y 48). Como ya se ha visto en cuanto al uso de comparaciones, también este recurso va a ser mucho más utilizado para las zozobras del amor que en otro tipo de manifestaciones sentimentales, puesto que aparece en pocas de las restantes cuarenta y dos Cartas de temática amorosa (4, 9, 10, 15, 18, 20, 21, 32, 34, $36,37,38,56,62$ y 64), aun teniendo en cuenta que en algunas de ellas son varias (dos en las Cartas 4 y 18, tres en la 15, 21 y 32, seis en la 34 y 64).

Algunas expresiones denotan con vehemencia la indignación, y los teóricos nos invitan a utilizarlas:

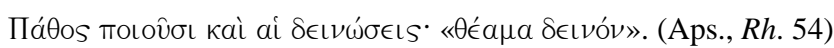

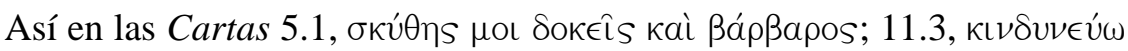

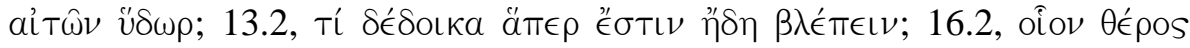

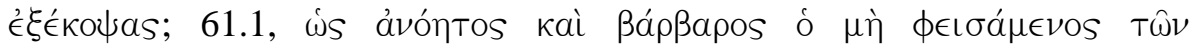

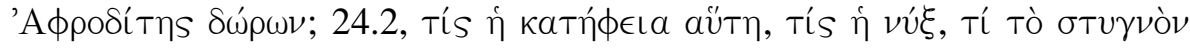

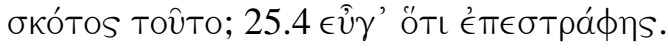

A estas expresiones pueden unirse los lamentos:

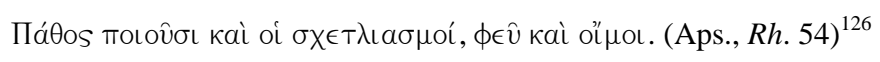

No son muy frecuentes en nuestro epistolario, pero los dos ejemplos que tenemos pertenecen a la serie del lamento, con $\phi \in \hat{v}$ en las Cartas 13.3 ( $\phi \in \hat{v}$.

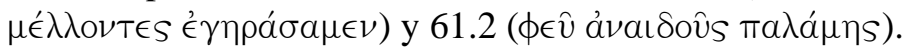

Asimismo tienen fuerza patética las invocaciones y las repeticiones; estas las comentaremos en el apartado del estilo ${ }^{127}$ y aquellas ${ }^{128}$ se emplean para

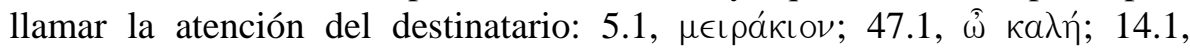

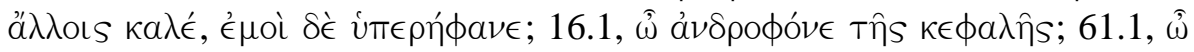

126 Estas exclamaciones también transmiten $\hat{\theta} \theta 0 s$, son propias de un estilo sincero y simple (Hermog., Id. 321.19 ss.) y suelen expresar quejas ( $\sigma \chi \in T \lambda \iota a \sigma \tau \iota k a i ́)$, vid. Hermog., Id. 352.16 ss.

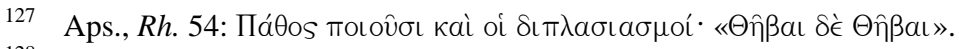

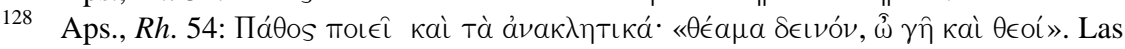
invocaciones confieren espontaneidad al discurso, como indica Hermógenes (Hermog., Id. 360.13 ss.). 


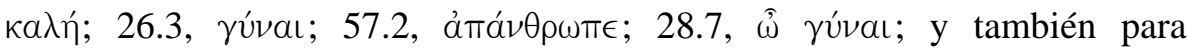

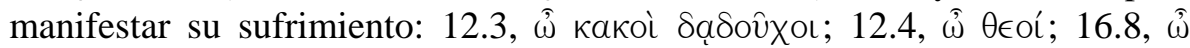

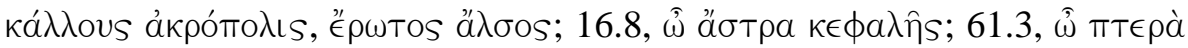

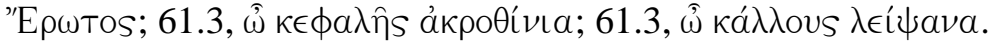

A través de discursos imaginarios, dibujando imágenes en nuestro discurso o bien recreando las palabras del rival o de la víctima, pueden expresarse también emociones: ${ }^{129}$

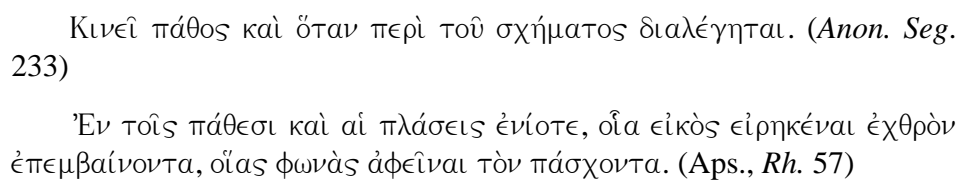

Así pronuncia discursos imaginarios el remitente en la Carta 26 al

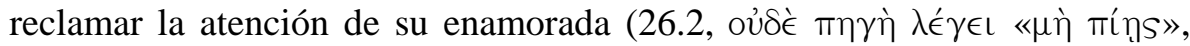

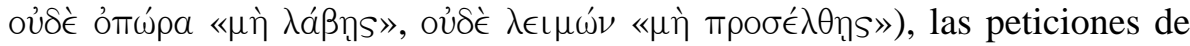

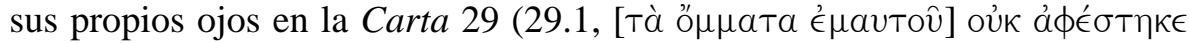

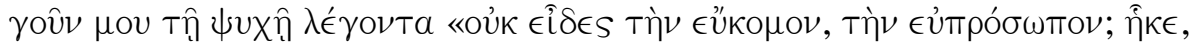

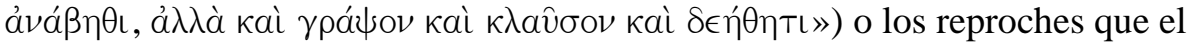

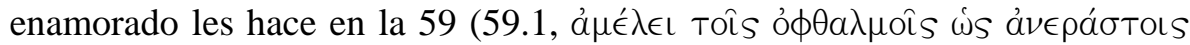

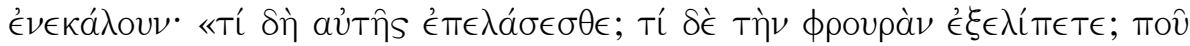

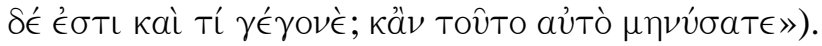

Asimismo se dibujan imágenes en el discurso, como en la Carta 7 (7.1,

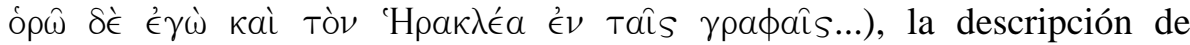
Agamenón en la Carta 24 y las palabras finales para la amada (24.2, тís i $\kappa a \tau \eta ́ \phi \in \iota \alpha . .$.$) , la imagen que evoca la referencia a la flor del jacinto, brotada$

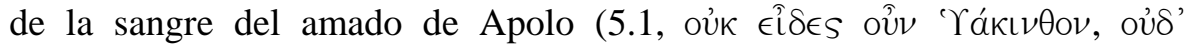

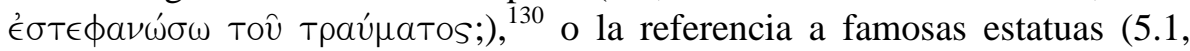

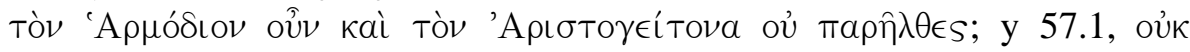

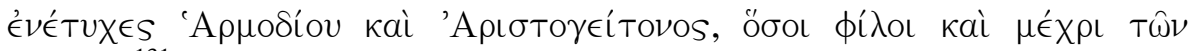
$\xi(\phi \omega \nu ;){ }^{131}$

Igualmente se recrean las palabras del rival o de quien sufre, como la propuesta de un trato y la respuesta de la díscola amada en la Carta 28 (28.4,

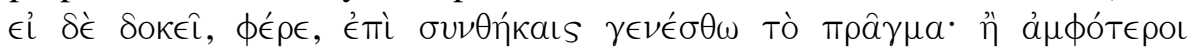

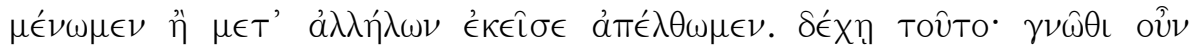

129 Vid. Longin. 15.1-2 (cf. 15.9 para el efecto de las imágenes en la oratoria).

130 Para este pasaje (5.1) vid. el comentario que sigue a la selección de Cartas.

131 Vid., acerca del texto, el comentario a este pasaje que sigue a la selección de Cartas. 
is $\left.\gamma \in v^{\prime} \in \sigma \theta a \mathrm{l} . ..\right)^{132}$ o la suposición del pensamiento de un muchacho (Carta

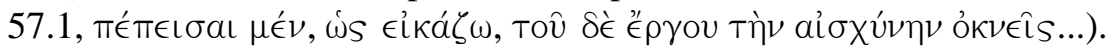

De las emociones que detallan los manuales, la que más interesa a la expresión del lamento es la compasión, ${ }^{\prime \prime} \lambda \in \mathrm{OS}$, explicada por el Anónimo

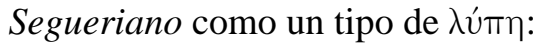

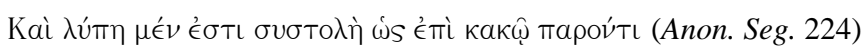

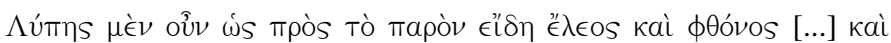

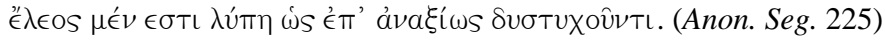

Es tan importante despertar la compasión del destinatario -dentro de la ficción literaria- como del lector, puesto que ello indica que se ha expresado correctamente el sufrimiento, ${ }^{133}$ por lo que los teóricos prestan una gran

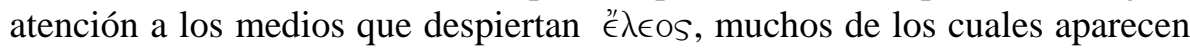
utilizados por Filóstrato.

Ya Aristóteles recogía indicaciones para conducir a la compasión, entre las que destaca todo aquello que produce dolor, ${ }^{134}$ por ejemplo los maltratos corporales y las vejaciones:

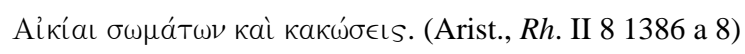

También el manual de Apsines hace referencia a los sufrimientos físicos:

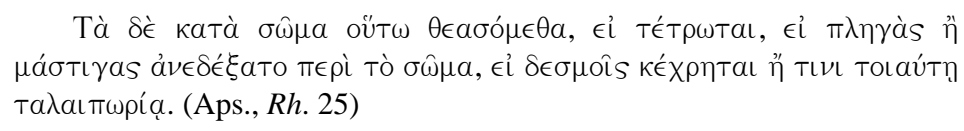

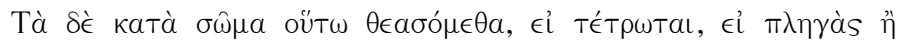

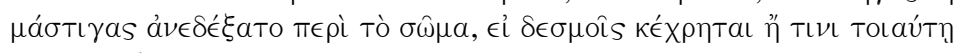

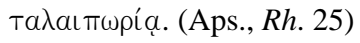

Así los remitentes de las Cartas 5.2 y 47.6 manifiestan que prefieren resultar heridos por la espada del ser querido; o recibir golpes, arrancarse el corazón y caminar sobre el fuego el de la Carta 23.2; el remitente se abrasa de amor en las Cartas 11.3 y 12.2 y 12.3; para sus sufrimientos la amada es la medicina en 29.4. También resultan dolorosos los males que provienen de

132 Esta recreación de un diálogo le sirve a J. Elsner, 2009, pp. 9 ss., como ejemplo de la frecuente ruptura del formato epistolar literario; sin embargo, vemos cómo puede atribuirse a los recursos retóricos de los que el autor se vale para este tema concreto, sin olvidar que el manual Sobre el estilo llama al género epistolar la mitad de una conversación (vid. infra), de modo que Filóstrato no estaría minando el género epistolar, sino siguiendo las indicaciones de su preceptiva.

133 Las instrucciones para transmitir esta emoción se documentan en diversas retóricas:

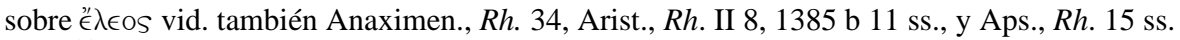

134 Arist., $R$ h. II 8, 1386 a 4 ss. 
la suerte, como la pobreza de las Cartas 7 y 23, la procedencia extranjera de la 28 o el exilio de la 39.

Para tener al auditorio a nuestro favor se ha de recurrir a la compasión y la filantropía, a la necesidad de comportarse con humanidad y sensibilidad:

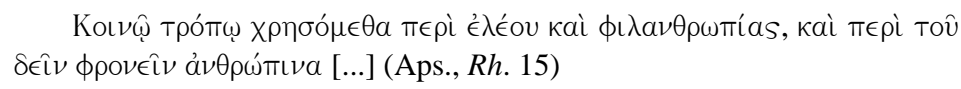

Por ello en la Carta 23.1 se ofrece amistad y trato amable, en la 39.5 el remitente ruega que erija un altar a la compasión y se apiade de él, en la 61.2 considera tan aberrante el corte de los cabellos de su amada que confiesa que él ni siquiera lo hubiera hecho a un cautivo de guerra.

También se hace necesario resultar más placentero con sentimientos agradables que con severos:

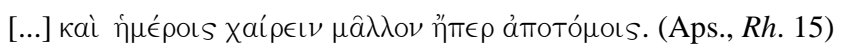

Como Agamenón, que resultaba bello y divino salvo cuando se enfadaba: «Agamenón, cuando contenía su furia, resultaba atractivo y no se asemejaba a un solo dios sino a muchos [...] Pero cuando con esa delicia de temperamento se comportaba indecorosa y fieramente con sus compañeros, un venado o un perro parecía y ya no se veían por ninguna parte los ojos de Zeus» (Carta 24.1).

Y para todo ello puede argumentarse que es cívico, útil, filantrópico y propio de una persona cultivada, además de ser más digno de alabanza:

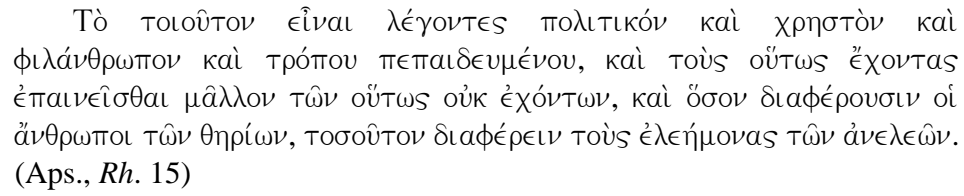

Y, así, se utilizan como modelos las obras de Menandro, los poetas épicos y los sabios en la Carta 16.1, 16.3 y 16.5, en la 23.1 se recurre a la condición de mujer libre, y a que actúe según las leyes en la 26. A ello añade Apsines que tanto se diferencian los hombres de las fieras cuanto los que sienten compasión de los que no, a lo que recurre Filóstrato en las Cartas $13.1,24.2$ o 25.1 .

En el contexto ateniense deben utilizarse las resoluciones y los actos del

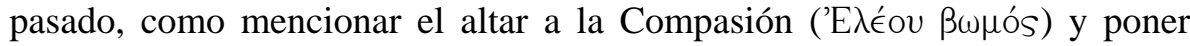
ejemplos de antiguos refugiados en dicho altar, como los hijos de Heracles: 


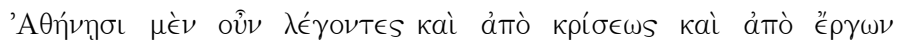

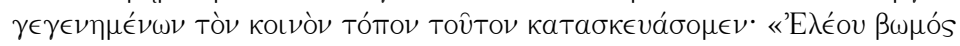

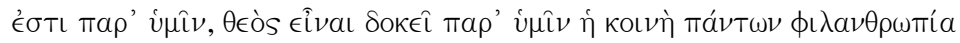

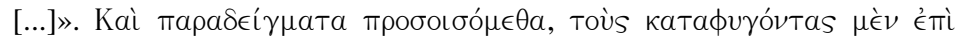

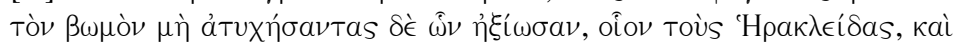

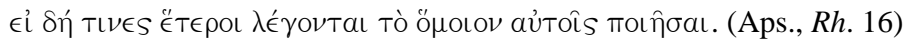
39:

Precisamente es este uno de los casos que Filóstrato expone en la Carta

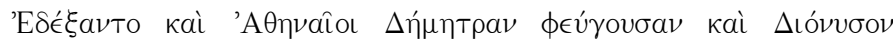

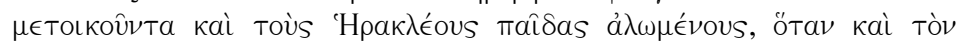

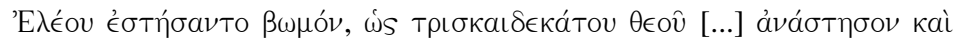

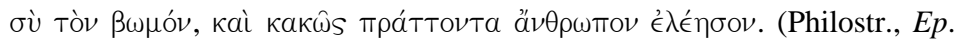
39.4-5)
\end{abstract}

Y también remite a este altar de la Compasión en 13.1 (Tòv 'E $\lambda$ éov

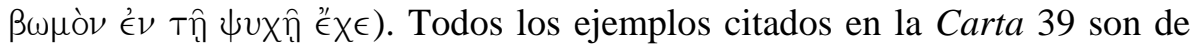
personajes atenienses -véase también 39.2-, a los que Apsines recomienda recurrir porque es bueno imitar tanto las virtudes ajenas como las propias:

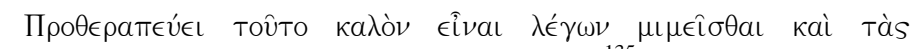

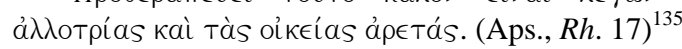

Asimismo resulta efectivo traer a colación las buenas acciones realizadas de forma desinteresada:

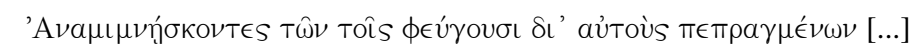

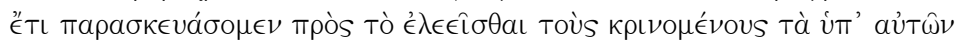

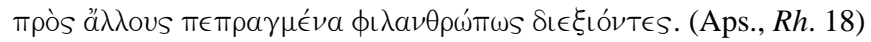

Así son todos los actos y sacrificios que los enamorados realizan gratuitamente -Cartas 7.4-7 y 23.2- o la preocupación sincera únicamente por el bienestar del destinatario -Carta 25.

Despiertan la compasión los cambios de fortuna de mejor a peor, sobre todo cuando se producen de forma inmerecida; para potenciar su efecto sobre el público se pueden subrayar las cualidades del sujeto, mencionar el causante y los motivos del sufrimiento:

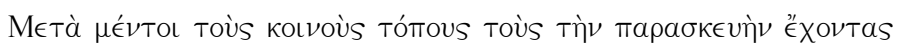

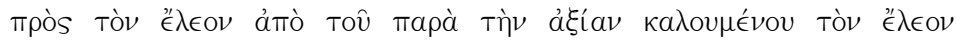

135 Texto de las ediciones de L. Spengel \& C. Hammer, 1894, y M. R. Dilts \& G. A.

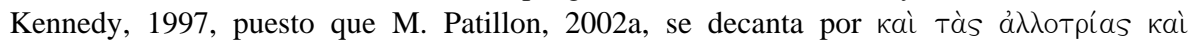
$\xi \in \nu$ เò̀s ảpetás. 


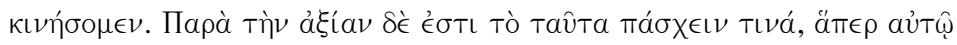

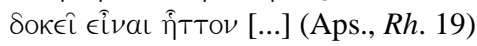

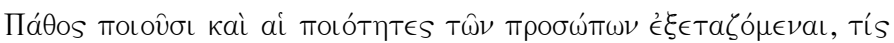

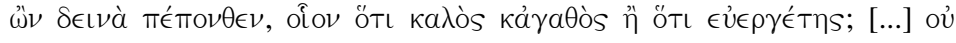

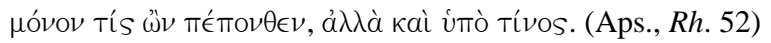

Manifestar lo inmerecido del padecimiento ya lo mencionaban Anaxímenes y Aristóteles como recurso para hacer a las personas dignas de compasión:

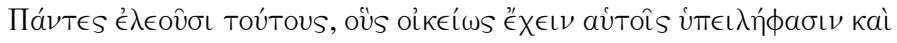

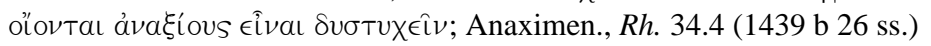

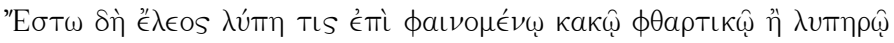

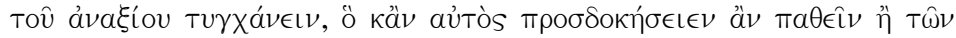

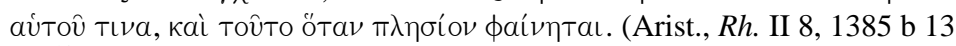
Ss. $)^{136}$

Esos cambios de mejor a peor los asume el remitente como algo inmerecido, y así los transmite en sus Cartas, más desdichados si cabe

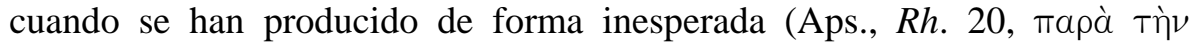
$\dot{\epsilon} \lambda \pi^{\prime} \delta \alpha$ ). Siempre en relación con un muchacho o una mujer anónimos para nosotros, las causas son variadas: el desprecio del ser querido en la 14, los ojos que han permitido que el amor le derrote y trastoque su vida en la 12 y la 29, el inexorable paso del tiempo y su inminente envejecimiento por la indecisión del destinatario en la 13 , el inesperado corte de pelo de los amados que ha destruido su belleza en la 16 y la 61, el enfado que sufren por parte de sus enamorados en la 24 y 25, los ojos que se han descuidado y han perdido a su amada en la 59.

Apsines insiste en este recurso y recomienda destacar el bienestar del que antes se disfrutaba, puesto que las comparaciones entre bienes y males mueven a la compasión, en especial los que vuelven su mirada atrás:

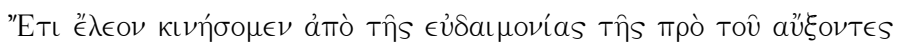
aủińv. (Aps., Rh. 21)

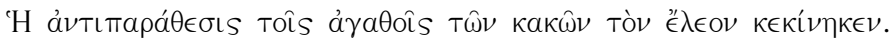

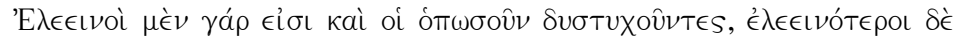

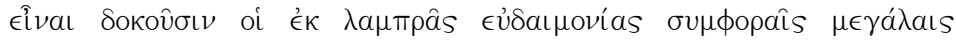

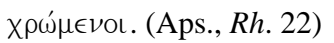

136 Para Aristóteles también era importante ponerlo a la vista (Arist., Rh. II 8, 1386 b 7).

Monografías de Filología Griega 20. ISSN 1136-0860 


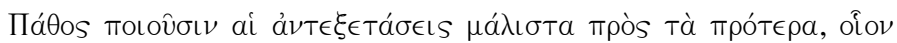

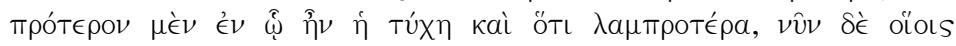

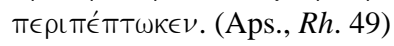

Así aconsejaba Anaxímenes utilizar pasado, presente y futuro para despertar la compasión de los jueces en un discurso defensivo:

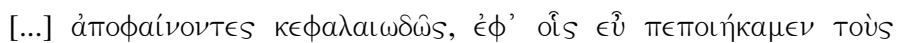

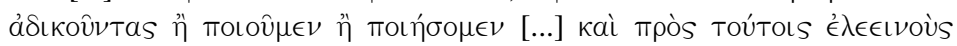

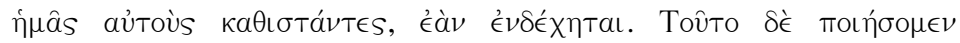

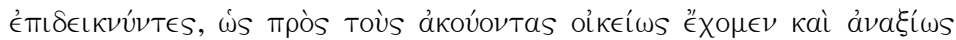

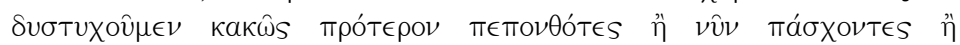

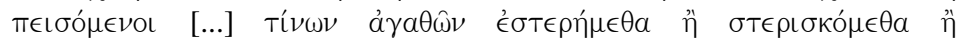

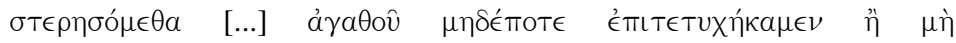

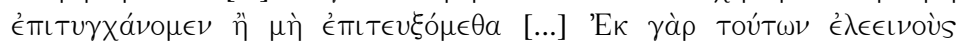

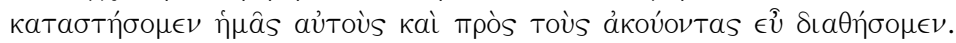
(Anaximen., Rh. 36.47-49, 1444 b 37 ss.)

Y también se mencionan en los manuales de progymnasmata estas comparaciones temporales para componer etopeyas: Hermógenes propone comenzar por las dificultades del presente, pasar a las bondades del pasado y terminar lamentando las desgracias del futuro, sobre las que Apsines recomienda exponer el temor que producen. En efecto, otra de las emociones que enumeraba el Anónimo Segueriano era el miedo de un mal venidero, que podía ser de dos tipos, miedo al deshonor y al fracaso:

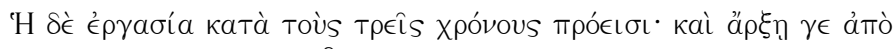

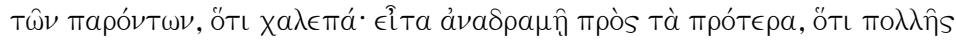

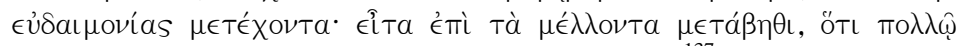

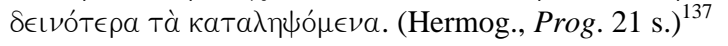

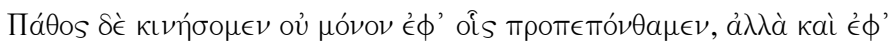

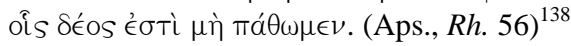

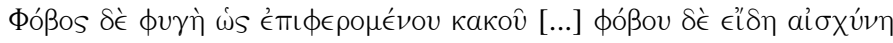

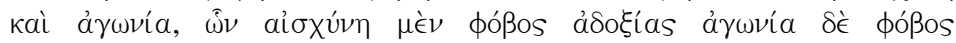

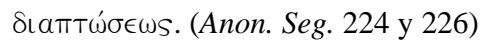

En la Carta 11 recuerda cuántas veces ya ha abierto sus ojos para librarse de ese amor, pero este permanece inmutable ante los sufrimientos

137 Aftonio y Nicolao tienen estas mismas instrucciones con ligeras variaciones (cf. Aphth., Prog. 35, o Nicol., Prog. 65 s.). Este precepto solía aplicarse a todas las etopeyas, vid. J. Ureña Bracero, 1999, pp. 333 s. y nota 37.

138 Similar era la descripción del temor que hacía Aristóteles (Rh. II 5, 1382 a 20 ss.). Vid. también Aps., Rh. 21 y 49. 
del remitente, que se abrasa; en la 12, desde que el amor se ha apoderado de su corazón a través de los ojos, su vida es un infierno, por lo que les desea que pasen las noches en vela, que ardan, se consuman y no encuentren liberación alguna; algo similar ocurre en la Carta 29, en la que se habla del bienestar anterior a la llegada del amor, que le causa ahora grandes sufrimientos, cuya cura sería que su amada le aceptara; en la 14 se oponen al actual rechazo los deseos para el futuro del esquivo amado: con barba y despreciado a su vez por otros; el presente en la Carta 13 significa disfrutar del amor, pero si el destinatario sigue vacilando le espera pronto un futuro en el que será viejo, barbudo y feo; la belleza anterior de los destinatarios de la 16 y la 61 ha desaparecido ahora debido a que se han cortado el pelo; rechazado por un muchacho sólo le queda al autor de la Carta 48 seguir con su desdicha y disfrutar de la mala reputación que no va a dejar de tener el otro; en la 59 reprocha a sus ojos haber perdido de vista a su amada, con lo que se enfrenta a un presente doloroso, y sus posibilidades futuras se limitan a buscarla y seguirla adonde haya ido, aunque sea al campo, donde él realizará casi cualquier labor por ella.

A fin de mostrar la desdicha y el sufrimiento de los infortunados de modo que despierte compasión, recomienda Apsines tres тómol en relación con el alma, el cuerpo y las circunstancias externas:

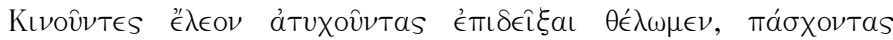

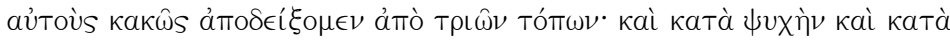

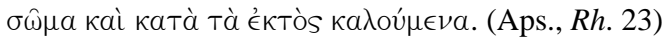

En el caso del alma se refiere al amor, la pena, la locura y cosas parecidas:

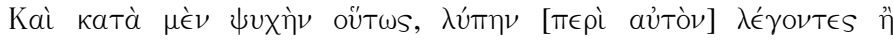

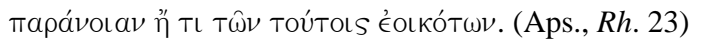

Para el primero de ellos puede exponerse, por ejemplo, si uno, maltratado por la mujer a la que ama, se halla en peligro por su causa:

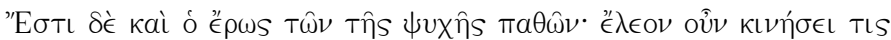

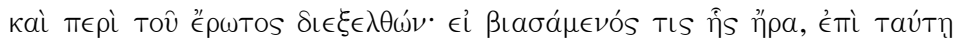

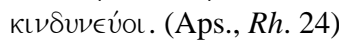

Es conveniente, además, explicar las consecuencias que se derivan de estos sufrimientos del alma:

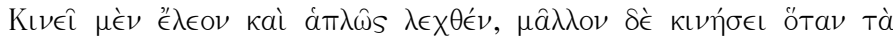

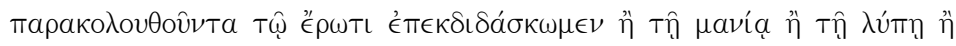

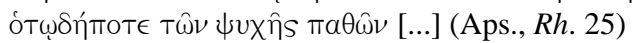




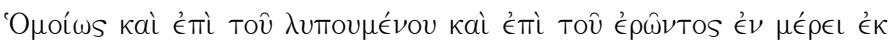

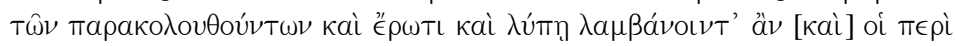

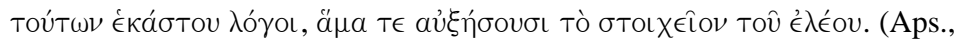
Rh. 26)

Así son varias las descripciones que encontramos de los dolorosos efectos del amor sobre el alma del autor (Cartas 11, 12, 29.1-3, 39.5, 50 y 59.1) e incluso en la Carta 11 manifiesta el peligro que corre (11.3, kaì Tís ó

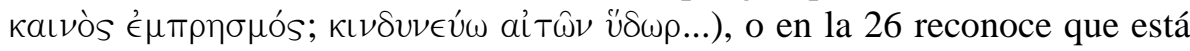

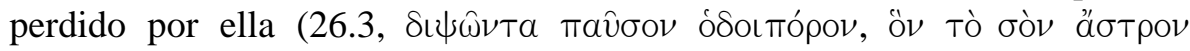
$\dot{\alpha} \pi \omega \dot{\lambda} \lambda \in \sigma \in \nu)$.

El segundo тótros, los sufrimientos corporales, ya se ha comentado antes, y en las Cartas 7 y 23 se ejemplifica el tercero de esos тómol, relacionado con las circunstancias externas, ${ }^{139}$ pues se recurre a la falta de riquezas para despertar compasión, además de defender las bondades de este estado.

Otro medio para suscitar la compasión consiste en que el sujeto se acuse a sí mismo; este recurso ofrece muchas posibilidades de utilización y uno de los ejemplos de Apsines muestra a un acusado en un juicio que solicita su muerte inmediata:

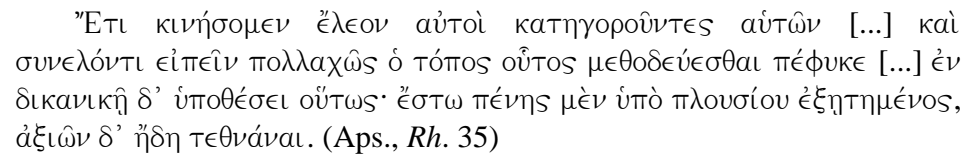

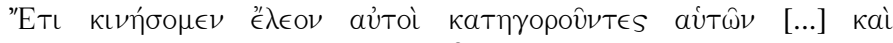

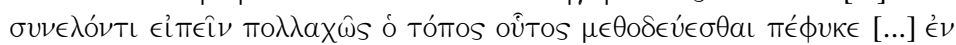

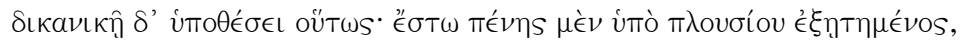

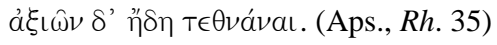

Esto mismo lo recogen también muchas de las Cartas de Filóstrato: el remitente pide al destinatario que lo hiera con una espada en las Cartas 5.2 y 47.6; en la Carta 12 y en 29.1 y 59.1 acusa a sus propios ojos de ser los causantes de su desgracia; y en la 13.3 se culpa a sí mismo por detenerse a suplicar al destinatario y perder el tiempo.

No es raro en estas Cartas que el remitente dirija sus palabras a diferentes objetos, y así se refiere a los ojos en 12.3 y 59.1, a los cabellos cortados en 16.8 y 61.3, a la mano que los ha cortado en 61.2, ya que también esto puede suscitar la compasión:

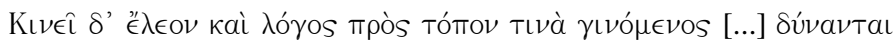

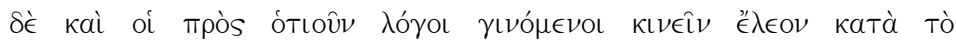
iтокєí $\mu \in v O \nu$. (Aps., Rh. 36)

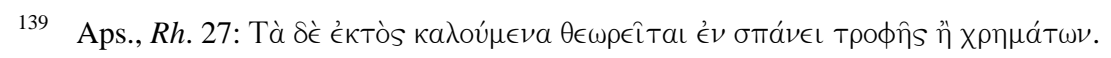


Se despierta compasión cuando no ocurre lo que debería haber sucedido o al contrario:

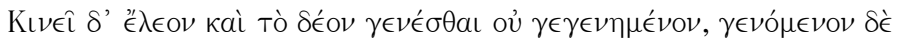

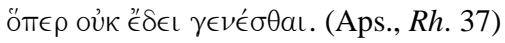

Y, de ese modo, se lamenta en la Carta 16 porque los cabellos de su amado no deberían haber sido cortados (véase especialmente 16.1) o en la 28 porque la hermosa debería elegir sus amantes por el carácter y no por su procedencia.

Nuestras Cartas en general se preocupan por evidenciar las palabras y los actos de los desafortunados remitentes, además de subrayar tal condición en cada uno de ellos, de modo que mueven los ánimos hacia la compasión:

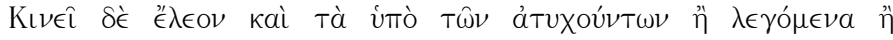

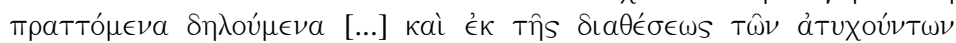

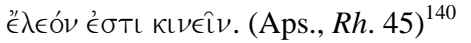

Uno de los casos que Apsines utiliza para ilustrar este aspecto se refiere a los sentimientos que van a invadir a un hombre pobre enfrentado, por ejemplo, a uno rico en la asamblea, lo mismo que encontramos en las Cartas 7 y 23 pero aplicado al amor:

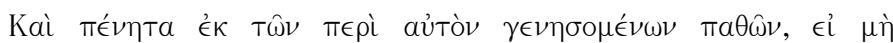

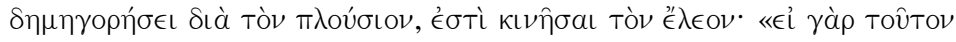

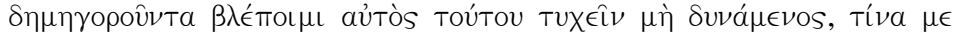

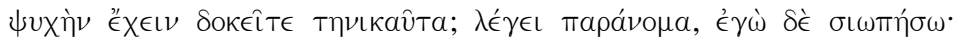

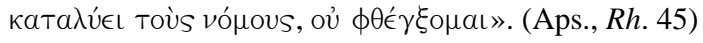

Lamentar la propia soledad suscita también la compasión del público: Rh. 46)

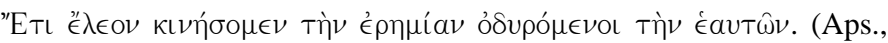

El enamorado remitente deplora la desdicha que le produce la soledad y la ausencia de su amada, que afecta incluso a los dioses de la ciudad:

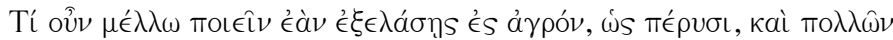

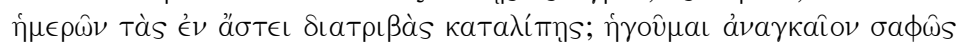

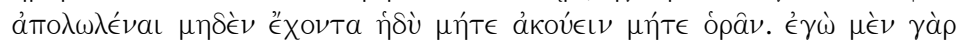

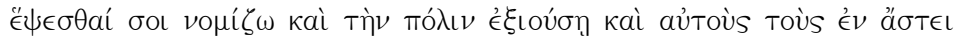

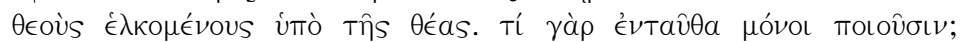
(Philostr., Ep. 59.2-3)

140 Aristóteles también señalaba que las acciones y las palabras y cosas similares de los que se hallan en sufrimiento provocan compasión sobre todo por su cercanía (Arist., $R h$. II 8 , 1386 b 2 ss.).

Monografías de Filología Griega 20. ISSN 1136-0860 
A la hora de expresar las emociones no es conveniente, según la teoría retórica que las estudia, un gran ornato ni tampoco la acumulación de pensamientos, sino que es preferible un estilo sencillo y claro a la par que agradable, cierta brevedad, figuras vivas y una composición relajada, y, en cuanto al vocabulario, son propios del que habla con emoción los compuestos, las acumulaciones de epítetos y los términos poco habituales. ${ }^{141}$ A continuación se va a analizar este tercer gran elemento o argumento

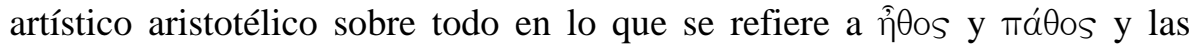
circunstancias que rodean los textos protagonistas de este estudio. Por ello serán relevantes, además de los manuales de retórica, los dedicados al estilo $y$, en especial, al estilo epistolar.

Del estilo apropiado para la composición epistolar se preocuparon en la Antigüedad desde el punto de vista más puramente teórico y también los propios literatos que escribían cartas manifestaron su interés en ello. El manual

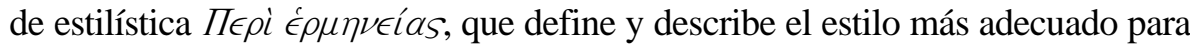
la epistolografía, es un tratado que se inserta dentro de la tradición retórica, con gran influencia, por ejemplo, de los primeros peripatéticos, Aristóteles y Teofrasto. ${ }^{142}$ Por otra parte, los escritores de la Antigüedad de los que se conservan cartas recibieron cierta formación retórica y compusieron, en su mayoría, obras de otros géneros, en las que consciente o inconscientemente aplicarían también sus conocimientos sobre retórica. Por ello no ha de extrañar que coincidan los textos de nuestras Cartas con indicaciones de tipo teórico y también con las reflexiones propias de un escritor avezado.

En el manual de Demetrio se establece como apropiado para la escritura de cartas el estilo 'simple' ( $ڤ \times \chi \nu o ́ s),{ }^{143}$ al que concede la posibilidad de mezclarse con otro de sus cuatro principales tipos de estilo, el 'gracioso' o 'elegante': ${ }^{144}$

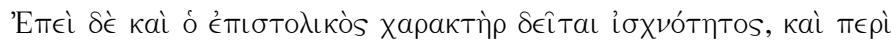

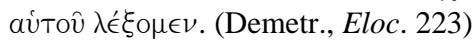

141 Vid. Aps. Rh. 55, 48; Anon. Seg. 141; Longin. 19 y 21.1-2; Arist., Rh. III 7, 1408 b 11 ss.

142 Vid., por ejemplo, P. Chiron, 1993, pp. vII ss. y XXIV ss.

143 Demetr., Eloc. 190 ss.

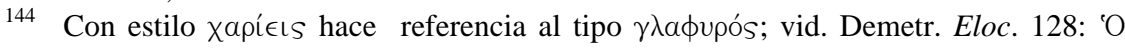

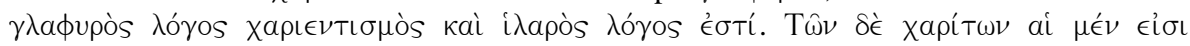

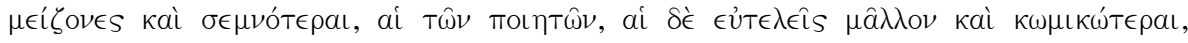

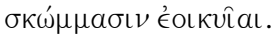




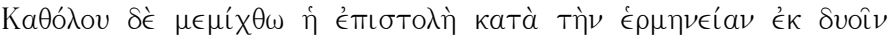

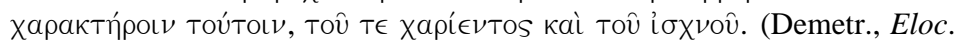
235)

El tratado sobre los estilos de Hermógenes, por su parte, indica que para

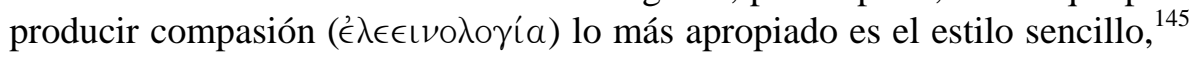
pero también es necesario hacer uso de la pureza, la dulzura y el deleite, estilos en estrecha conexión con esa emoción: ${ }^{146}$

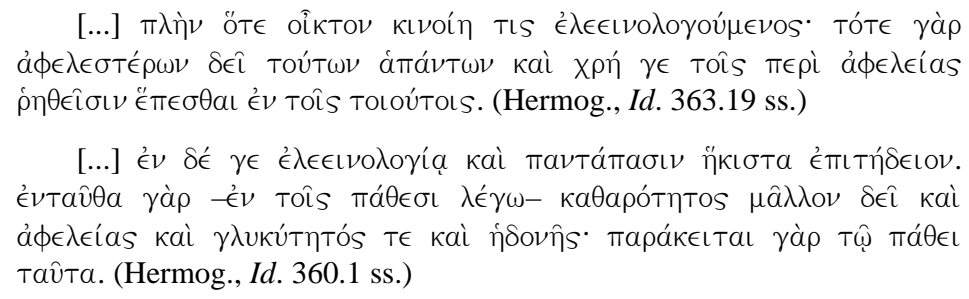

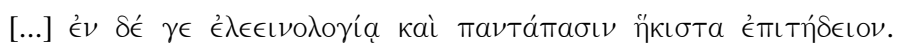

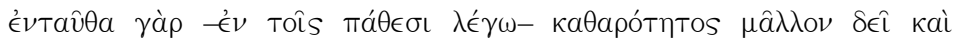

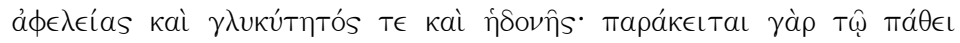
таv̂Ta. (Hermog., Id. 360.1 ss.)

Y, sobre la necesidad de utilizar un estilo sin artificio ni ornato, nos advierte Apsines en las líneas que dedica al mátos en su capítulo del epílogo:

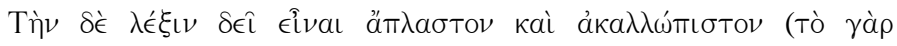

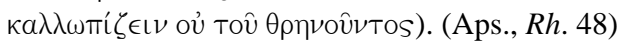

Será, por lo tanto, esencial para los objetivos de nuestras epístolas, hacer uso de un estilo simple, que admite rasgos de otros modos, cuyas características van a ser analizadas a continuación.

Pertenecen a este estilo las formas vivas y vigorosas, según nos indica

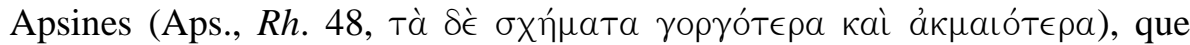
también aparecen en Sobre el estilo (Demetr., Eloc. 209 ss.), donde se explica que a través de la precisión de no omitir ningún detalle se consigue ese tono vivo: ${ }^{147}$

145 Algo que ya Aristóteles avanzaba a la hora de destacar la capacidad de transmitir

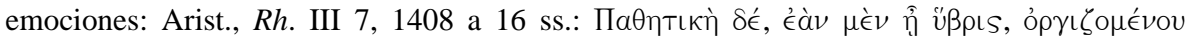

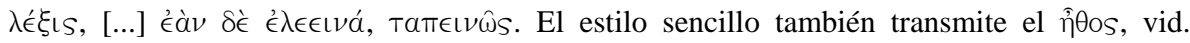
Hermog., Id. 321.19 ss.

146 Como pone Hermógenes de manifiesto en varios aspectos relativos a ese estilo

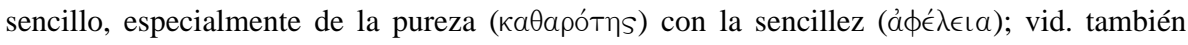
Hermog., Id. 327.24 ss., 328.16 ss., 329.5 s. y 329.20 ss.

147 Puede aumentarse esta viveza a través de la repetición, sobre la que se hablará unas líneas más abajo (vid. Demetr., Eloc. 211).

Monografías de Filología Griega 20. ISSN 1136-0860 


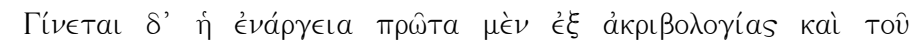

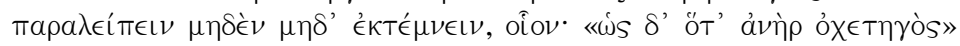

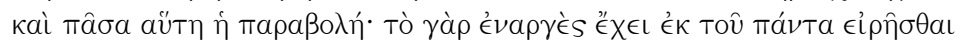

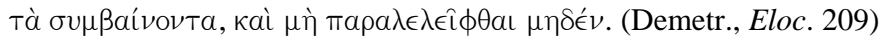

También Apsines hace referencia a esta évá $\rho \gamma \in\llcorner\alpha$, que, utilizada para describir a los desafortunados, puede despertar compasión, y, asimismo, el Anónimo Segueriano nos prescribe la descripción vívida y detallada (i

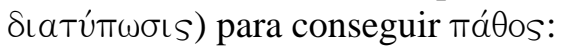

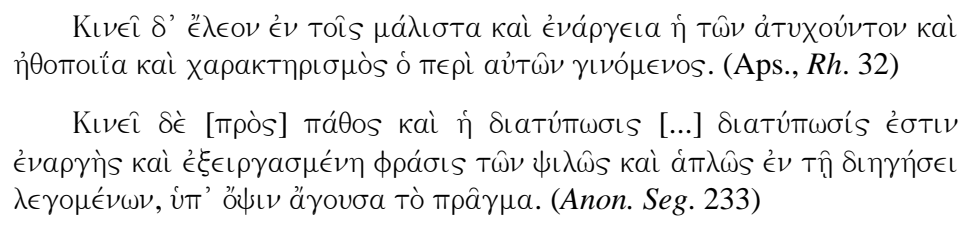

Esa precisión y descripción vivaz podemos ilustrarla con algunos ejemplos procedentes de la selección de Cartas que nos ocupa; así puede destacarse la rica descripción que del pobre comparado con el rico se hace en la Carta 7, de la temida barba de su amado en la 13 (sobre todo 13.2 y 13.3), de la importancia de una cabellera y su omnipresencia en personajes de la mitología, personas, elementos de la naturaleza y en dioses, en la Carta 16 y de forma parecida en la 39 pero relativo al exilio, o el detallado dibujo del ser amado enfadado en la 24 y 25 . En realidad podrían incluirse aquí todas las comparaciones que se han señalado al hablar del má日os, tal y como lo señala el manual Sobre el estilo (Demetr., Eloc. 209).

A este respecto señala también la preceptiva antigua que puede resultar conveniente referir un asunto poco a poco, de forma progresiva, de modo que se mantenga el suspense en la audiencia, ${ }^{148}$ y Sobre lo sublime recomienda las gradaciones para aumentar la emoción, ${ }^{149}$ como las que pueden verse en algunas de las Cartas, como la 7, en la que comienza el enamorado pobre la comparación con los dioses, continúa con los personajes históricos, a los que sigue el pueblo, después de forma indeterminada el rico frente al pobre para acabar contraponiendo al rico con él mismo. Igualmente puede hacerse referencia en este punto al suspense que logra crear el autor en algunas de sus misivas, al no desvelar desde el comienzo el objetivo del escrito, como la 24, en la que solo al final realiza su petición al ser amado

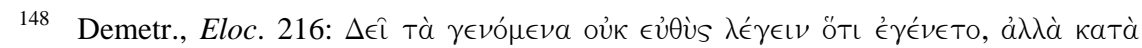

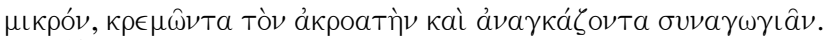

149 Longin. 23.1. 
directamente (24.3, «sonríe, cálmate, devuélvenos la luz de tus ojos»); o la 28, en la que hasta el tercer párrafo no revela sus intenciones. Además, esta gradación puede llevar a crear un efecto sorpresa (Demetr., Eloc. 152, $\dot{\eta}$

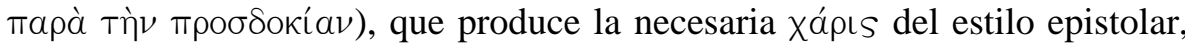
como el ofrecimiento de la propia vida en la Carta 5.2 y en la 47.6; la composición de un epitafio a unos simples cabellos al término de la 16.8; la gracia final en la 59.4 cuando el remitente se ofrece a realizar cualquier labor agrícola para su amada salvo una: «ordeñar leche. Sólo tus pechos quiero tocar dulcemente».

Igualmente se puede conferir gracia al estilo mediante la cita de los versos de otro autor, ${ }^{150}$ como hacen las Cartas 29.3 (Ilíada XXIII 724) y 24.1 (Ilíada II 478 s.). Y también sirven en ocasiones los reproches disimulados o encubiertos, ${ }^{151}$ como el de la Carta 24, pues no recrimina directamente el aspecto fiero y desagradable de su amado, sino el de Agamenón a través de unos versos homéricos.

Otro medio para transmitir sencillez, según Hermógenes, consiste en comparar argumentos a animales o plantas, y estas últimas confieren mayor simplicidad y son más propicias para transmitir dulzura. ${ }^{152}$

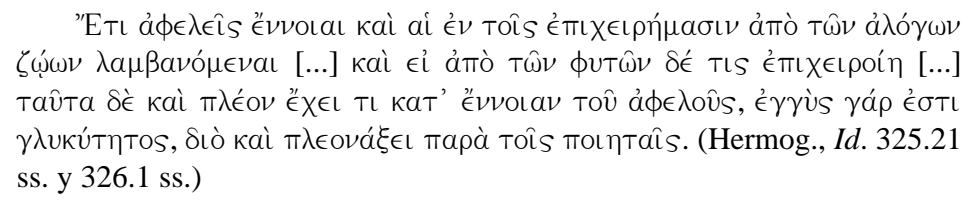

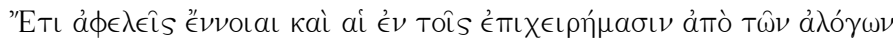

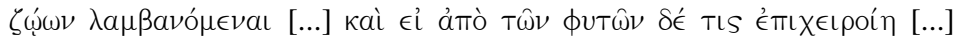

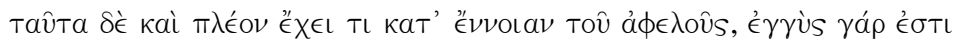
$\gamma \lambda$ ss. y 326.1 ss.)

Este recurso es frecuente en nuestras Cartas, como en la 16, que, al lamentar el corte de los cabellos de su amado, hace referencia a la belleza que producen las «melenas» en el curso de los ríos, en las montañas, en sus cañadas, en las islas del mar, en los pitones de los toros, en los sotos de los ríos, en los leones, caballos y gallos (16.3-4). Destaca la belleza de las espinas del rosal porque, a pesar del daño que producen, dan una hermosa flor, argumento que utiliza en la Carta 25 el remitente para convencer a su enamorada de que cese en su enfado (25.3). Y en su pareja, la Carta 24, se

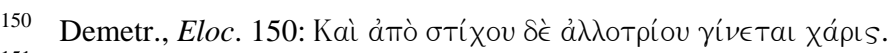

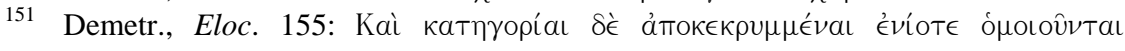

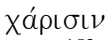

152 La efectividad de la comparación para provocar má $\theta$ os ya se ha comentado antes y también Demetrio indica que las comparaciones producen xápıs (Demetr., Eloc. 145, 146, 160).

Monografías de Filología Griega 20. ISSN 1136-0860 
utilizan venados, perros, jabalíes, serpientes, lobos y demás bestias irracionales. De igual manera, intenta vencer las reticencias de su amada en la Carta 26 trasladando sus argumentos a las fuentes, frutas y praderas:

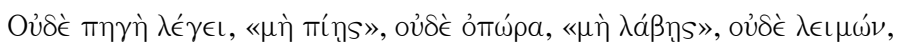

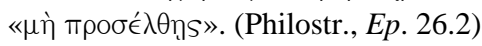

Y en esta misma Carta finaliza su súplica confesándose perdido por causa de la estrella de la destinataria (26.3).

A través de varios de los recursos que hemos ido comentando se ha podido apreciar el especial gusto de Filóstrato por las enumeraciones, ${ }^{153}$ recomendadas por Hermógenes ${ }^{154}$ para imprimir sencillez al discurso

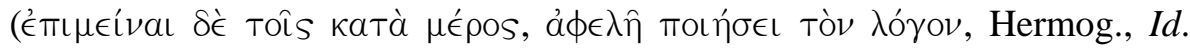
326.18 s.). También Sobre lo sublime hace referencia a las acumulaciones, destacando la combinación de emociones con síntomas reales a través del

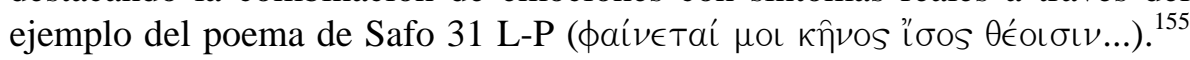
En ocasiones también Filóstrato recurre a esa combinación, como en la Carta 11 (11.2-3).

El vocabulario que corresponde a un estilo sencillo es el habitual y corriente, según nos indica la preceptiva retórica, ${ }^{156}$ pero debe tener también bellas palabras, como es propio del estilo elegante que nos explica Sobre el estilo, ${ }^{157}$ porque no ha de ser excesivamente vulgar, ya que, en ese caso, sería ridículo. ${ }^{158}$ En este manual se desaconseja en el estilo sencillo el uso de compuestos y de nuevas creaciones, ${ }^{159}$ pero, sin embargo, Aristóteles

153 Piénsese, por ejemplo, en las comparaciones de todo tipo comentadas en distintos puntos o en la acumulación de preguntas en varias Cartas.

154 Hermog., Id. 326.15 ss.

155 Longin. 10.

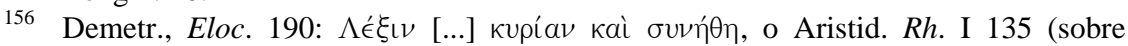

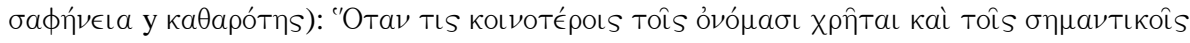

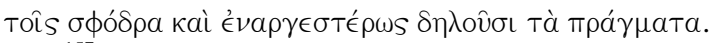

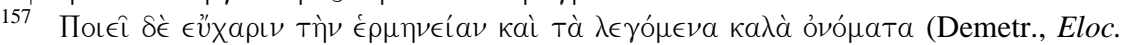
173), que son, según la definición de Teofrasto, las palabras agradables a los sentidos como la vista y el oído: vid. Demetr., Eloc. 173 s. También proporciona gracia en este estilo elegante

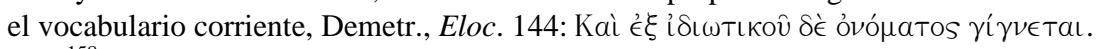

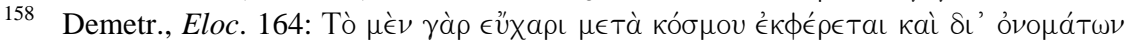

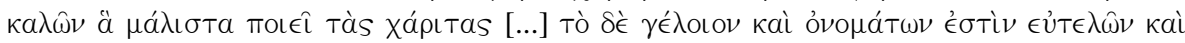

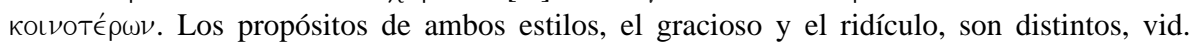
Demetr., Eloc. 168.

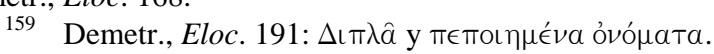


consideraba muy apropiados para la expresión de emociones, además de la acumulación de epítetos, los compuestos y las palabras raras: ${ }^{160}$

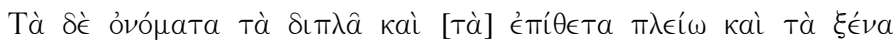

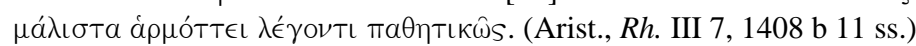

El vocabulario empleado en la selección de Cartas de Filóstrato responde en general a estas indicaciones. Por una parte es sencillo y habitual,

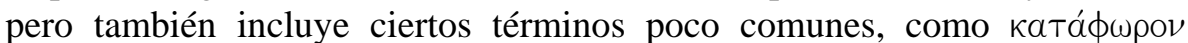

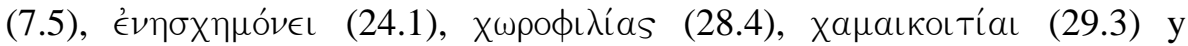
$\epsilon \epsilon \pi \rho o ́ \sigma \theta \in \sigma \mu \mathrm{ov}$ (50.2) que, además son compuestos, de los que encontramos

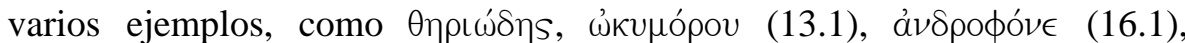

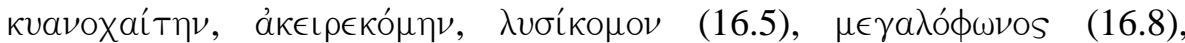

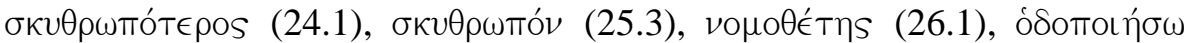
(59.4), ảкроӨ́́vıа (61.3).

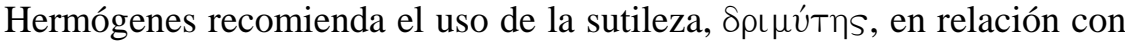
la sencillez y el deleite, ${ }^{161}$ en una de sus formas ${ }^{162}$ que consiste en emplear una palabra para significar un contenido que no es su propio sentido: ${ }^{163}$

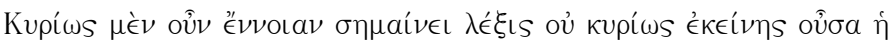

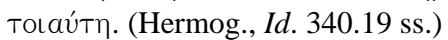

También Demetrio, en las indicaciones relativas a uno de los estilos propios del género epistolar, propone un medio que produce gracia, consistente en utilizar un término de forma poco habitual:

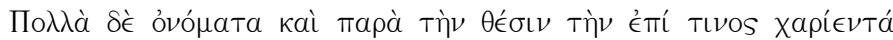

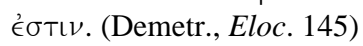

No es raro este recurso en las Cartas de Filóstrato, como en la 7, en la que tras la larga comparación del amante pobre frente al rico, termina el remitente atribuyéndose riqueza a sí mismo $(7.7, \pi \lambda$ ovt $\hat{\omega})$ pero en hechos intangibles:

160 Las expresiones poco habituales aparecen en otras retóricas: para Hermógenes son

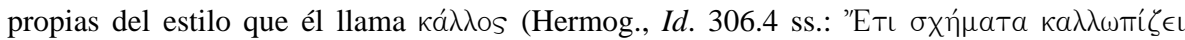

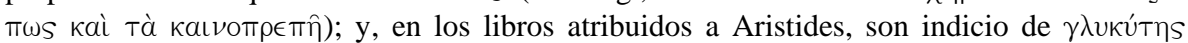

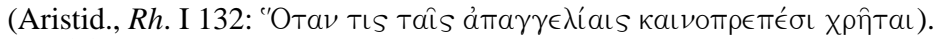

161 Hermog., Id. 339.16 ss. y 22 s.

162 Existen distintos tipos de $\delta \rho \iota \mu v ́ t \eta s$, vid. Hermog., Id. 339.20 ss., 339.25 ss., 342.3 ss., 342.19 ss. y 343.14 ss.

163 Vid. toda la definición y los ejemplos que proporciona en Hermog., Id. 339.25 ss. 
¿Quién puede permanecer fiel junto a un enfermo? ¿Quién compartir la vigilia? ¿Quién acompañar al campo de batalla? ¿Quién interponerse ante una flecha disparada? ¿Quién caer por ti? En todas estas cosas yo soy rico. (Philostr., Ep. 7.7)

De forma similar se emplea este juego de palabras en la Carta 23, que comparte temática con la 7 pero dirigida en este caso a una mujer. En la Carta 24 el remitente, tras manifestar la inconveniencia de que las nubes

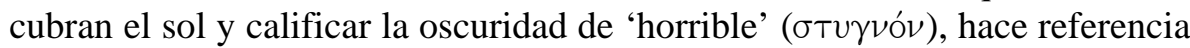
a la luz brillante de los ojos de su amado con el término ì $\mu$ épa:

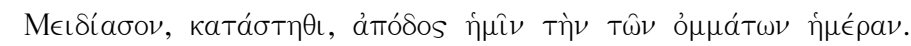

(Philostr., Ep. 24.3)

Muy repetido es este recurso en la Carta 16 en relación con los términos $\kappa о \mu \hat{\omega}, \kappa o ́ \mu \eta$, aplicados a las velas de las naves, las murallas de las ciudades, etc. Otro ejemplo aparece en la Carta 28, en la que los protagonistas se convierten en anfitriones de unos invitados inesperados: el amor y la belleza

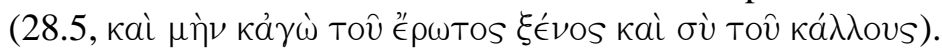

Es simple y además transmite îĐos la persuasión a través de expresiones solemnes:

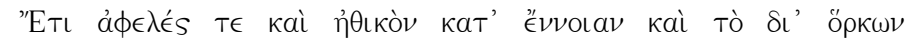

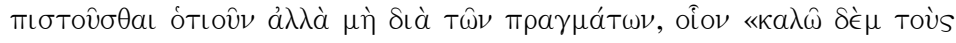

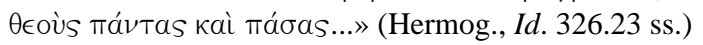

$\mathrm{Y}$ así se pronuncian en ocasiones nuestros enamorados: 14.2)

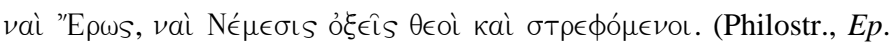

Hay más indicaciones en los manuales para conseguir ese estilo apropiado, como evitar el hiato de vocales largas y diptongos, permitiendo, al parecer, los encuentros cuando una de ellas es breve. ${ }^{164}$ En este aspecto es Filóstrato muy cuidadoso en nuestra selección de Cartas, ya que son pocos

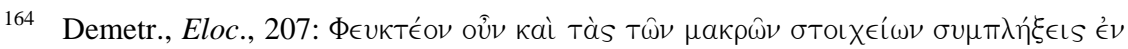

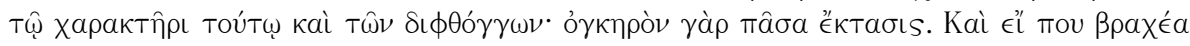

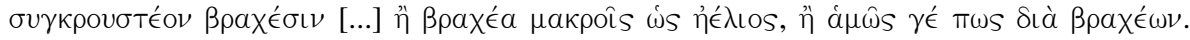

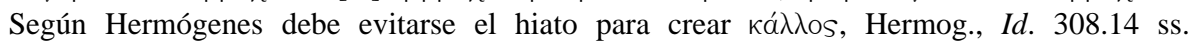
Siguiendo estas indicaciones no se han tenido en cuenta aquellas situaciones de hiato que

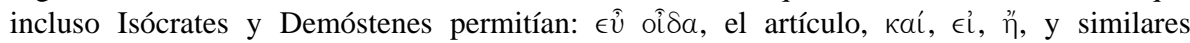
monosílabos, ni tampoco cuando hay pausa entre esas vocales (al final de un miembro o de una oración); vid. F. Blass, 1892, pp. 139 ss. y 159, y 1893, pp. 100 ss.; H. W. Smyth, 1984, p. 18. 


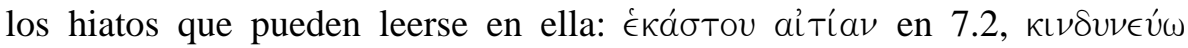

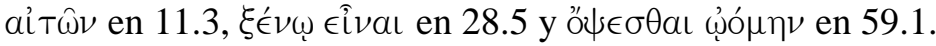

Además de un estilo simple, suele destacarse la importancia de la claridad y de la concisión en el género epistolar. Ya se ha comentado el testimonio de Demetrio respecto de la sencillez, en la que es característica

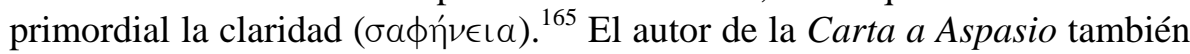
prestará gran atención a la claridad, muy importante en todo tipo de carta:

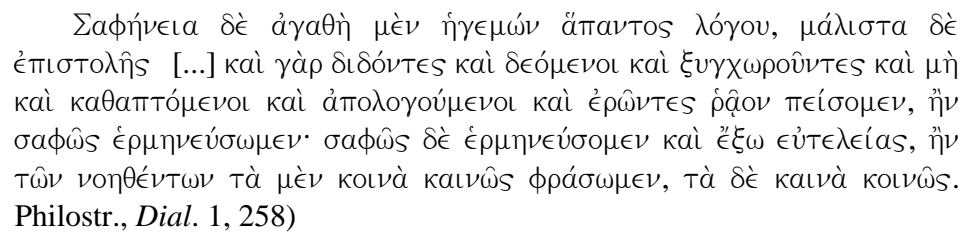

Entre las referencias de los manuales de Progymnasmata al estilo apropiado para la etopeya puede destacarse la recomendación de sencillez, claridad y concisión:

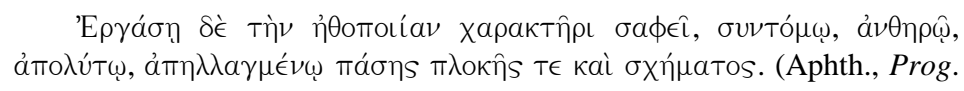

Y los manuales de estilo ofrecen diversos recursos para conseguir esa claridad, relacionada íntimamente con la sencillez y la pureza. ${ }^{166} \mathrm{La}$ expresión pura es la corriente, la empleada por todos:

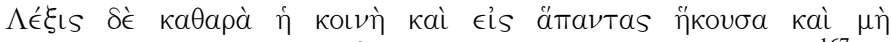

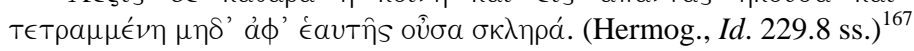

Además, en el estilo simple la persuasión se basa en la claridad y en el uso cotidiano:

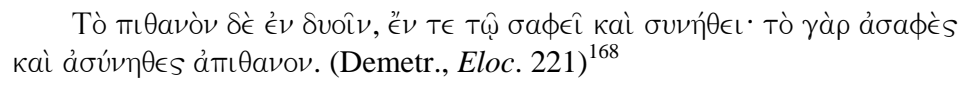

165 Demetr., Eloc. 191 ss., 223, 231; vid. H. Koskenniemi, 1956, pp. 21 ss. para la influencia de este tratado en autores posteriores respecto de la claridad necesaria en el estilo

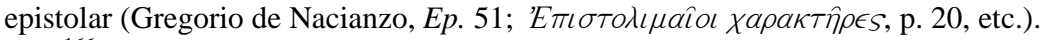

166 Vid., por ejemplo, además de las referencias ya antes citadas, Hermog., Id. $226.14 \mathrm{~s}$.

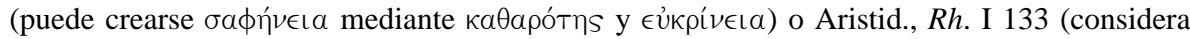

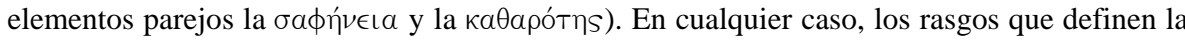
claridad y la pureza coinciden en buena medida en ambas retóricas.

167 El primer ejemplo que utiliza Hermógenes (Hermog., Id. 229.9 ss.) relega el uso de un término jónico en favor de otro ático por su aspecto fonético (el homerismo ảTapmós). 
En la Carta a Aspasio de Ravena la 'idea' de una carta, el término empleado por Hermógenes para hacer referencia al estilo, estaría entre el ático y la lengua coloquial elevada, sin llegar al aticismo:

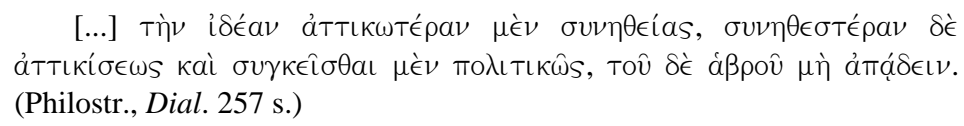

No es este el lugar para la realización de un completo y exhaustivo análisis de la lengua de las Cartas que nos la definiera de forma detallada, ${ }^{169}$ pero intentaremos, a través de una serie de rasgos relevantes, ofrecer una idea general de la lengua que utilizan.

Un rasgo significativo responde a las formas que mantienen o eliminan la iota intervocálica. ${ }^{170}$ Por ejemplo, la combinación de la conjunción

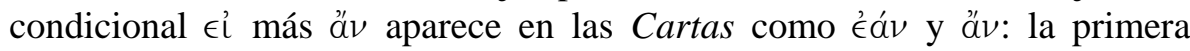
forma, que ya se usaba en griego clásico, se impuso en la koiné, puesto que, una vez se perdió la oposición de cantidad vocálica, ya no se diferenciaba åv

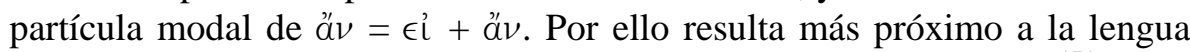

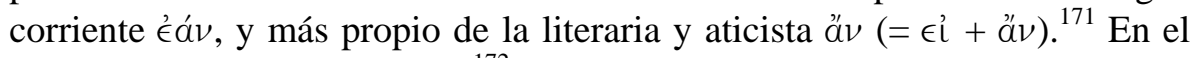
epistolario se emplean ambas, ${ }^{172} \mathrm{y}$, aunque la forma $\alpha ٌ \nu$ sea más cercana a la elevada lengua aticista, hemos de destacar que sería probablemente $\eta^{\prime} v$ la más aticista, puesto que rememora su uso en la poesía y prosa áticas bajo el influjo de la lengua literaria jónica. ${ }^{173}$ De hecho en su obra Filóstrato emplea las tres formas, pero en el epistolario se limita a las dos más comunes.

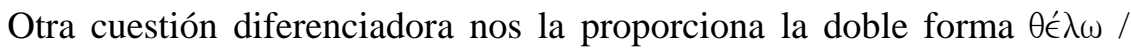

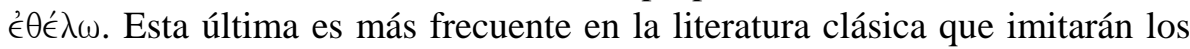
autores aticistas, por lo que abundarán en sus textos las formas $\epsilon^{\prime} \theta \in \lambda-,{ }^{174}$

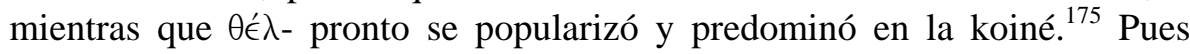

\footnotetext{
168 Ya se ha comentado la necesidad de un vocabulario corriente y habitual en el estilo simple (Demetr., Eloc. 190 ss.).

169 Sobre la lengua de las Cartas y sobre su relación con otras obras de Filóstrato vid. L. de Lannoy, 1997 pp. 2440 ss.

170 Vid. E. Schwyzer, 1968, pp. 236 y 312 s.; M. Lejeune, 1972, pp. 246 s.

171 Vid. W. Schmid, 1964d, p. 124; L. Radermacher, 1925, p. 204, y 1947, pp. 19 s.; E. Schwyzer \& A. Debrunner, 1966, p. 306; M. García Teijeiro, 1983, p. 251.

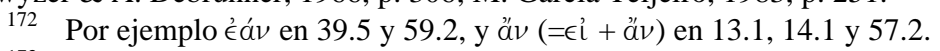

173 Vid. W. Schmid, 1964d, pp. 11 y 123 ss.

174 Vid. W. Schmid, 1964b, pp. 22 s., 1964c, pp. 32 s., 1964d, pp. 27 s. y 589 s.

175 Vid. E. Mayser, 1970a, p. 119; F. Blass \& A. Debrunner \& F. Rehkopf, 1979, p. 75.
} 
bien, nuestras Cartas se decantan claramente por la forma más corriente: 5.2,

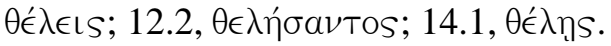

Sin embargo, en el uso de la preposición és en lugar de la coloquial y extendida $\epsilon i s$, se acercan ${ }^{176}$ las Cartas más bien a la tendencia aticista, que probablemente la entendió como propia del ático cuando en realidad procede su uso del jónico literario. Y por ello Filóstrato escribirá casi siempre la forma és. ${ }^{177}$

Y llegamos a uno de los rasgos que más recordaba a la lengua ática, el uso de la doble tau ${ }^{178}$ en lugar de la jónica y extendida doble sigma. ${ }^{179}$ Pero en este caso, como en muchos otros, dependemos de las grafías de unos códices que no siempre coinciden y que quizá nunca sabremos si recogen una escritura original o un cambio posterior. En la selección de Cartas que estudiamos aparecen ambas formas, quizá con un leve predominio de la

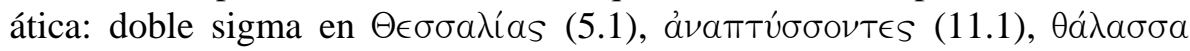

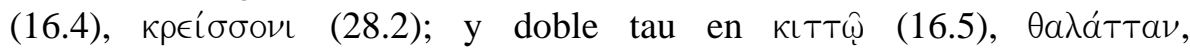

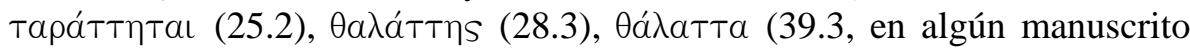

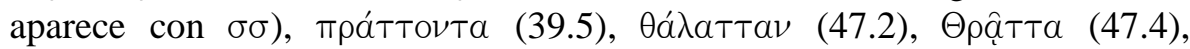

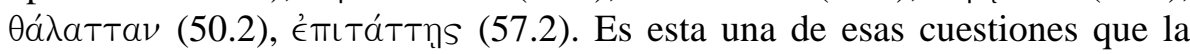
propia tradición manuscrita ha podido manipular caprichosamente, al igual que se refleja en las distintas ediciones. Sirvan de botón de muestra dos casos: en 5.1 suelen tener las ediciones $\Theta \epsilon \sigma \sigma a \lambda i ́ a s$ y, sin embargo, J. F. Boissonade ${ }^{180}$ y R. Hercher escriben doble tau sin atribuir este cambio a manuscrito alguno ni a sí mismos; de igual forma actúan R. Hercher y A. Westermann en 16.4 con $\theta a ́ \lambda a \sigma \sigma \alpha$, mientras que C. L. Kayser en su edición de 1944 escribe doble sigma y en la de 1970-71 doble tau sin indicación de ningún tipo. Normalmente el motivo que impulsa a un editor de estas características a imponer doble tau se debe a la clara ascendencia ática de este elemento, y en autores como Filóstrato, aticista reconocido, sería la

\footnotetext{
176 Se usa És en 7.4 (dos veces), 11.1, 11.3, 12.2, 12.2, , 26.1, 26.1, 29.3, 29.3, 48, 57.1

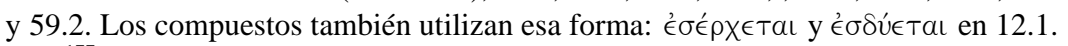

177 Vid. W. Schmid, 1964d, pp. 12 y 579 s.

178 Aunque también habrá autores áticos que empleen doble sigma debido a la influencia de la lengua literaria de prestigio, el jónico.

179 Sobre la génesis y desarrollo de estas dos formas fonéticas vid. E. Schwyzer, 1968, pp. 317 ss.; M. Lejeune, 1972, pp. 104 ss.; M. ${ }^{a}$ L. del Barrio Vega, 1990, pp. 293 ss., especialmente $307 \mathrm{~s}$.

180 Acerca de las distintas ediciones de las Cartas y de los manuscritos que siguen, vid. infra la introducción a la selección de Cartas (con un resumen de aquellas en la Tabla IV). 
forma esperada, pero, ya se ha comentado, no es la única que emplea. En nuestro caso, puesto que debemos fiarnos de los testimonios más directos, los manuscritos, en los que de forma generalizada para los autores de esta época fluctúan ambas formas sin un criterio definido, ${ }^{181}$ hemos de pensar que no era raro el uso de la forma hablada en sus composiciones, la doble sigma, mientras que se preocupaban con mayor o menor intensidad, en función de sus intenciones literarias, de utilizar doble tau. Y por ello no debe extrañar que incluso en una misma Carta se empleen ambas formas, ya que su convivencia era una realidad asumida, hasta el punto de que ocasionalmente se encuentra también la doble tau en la literatura y en los niveles más bajos de koiné, al igual que los autores aticistas empleaban ambas, aunque siempre con claro predominio de la forma ática. ${ }^{182}$

Algo similar ocurre entre los pares $\gamma\llcorner\gamma \nu$ - y $\gamma(\nu$-: la tendencia aticista se

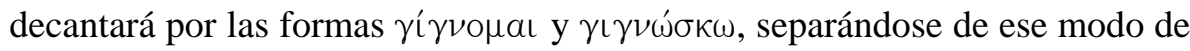
la lengua común, que había adoptado las formas de procedencia jónica

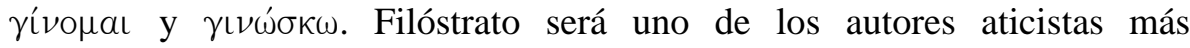
inclinados al uso de $\gamma \iota \gamma \nu$-, que se encuentra también de forma ocasional en la literatura en koiné ${ }^{183}$ Todos los ejemplos de las Cartas tienen esa forma alejada de la lengua hablada, pero reconocida también en otros niveles.

En el aspecto morfológico, puede destacarse el uso en las Cartas del verbo $\phi \theta a ́ v \omega$, cuyo aoristo antiguo era $\epsilon^{\prime} \phi \theta \eta \nu$, pero merced a ciertas extensiones analógicas, surgieron formas sigmáticas que tuvieron gran éxito

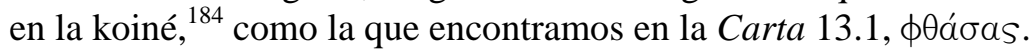

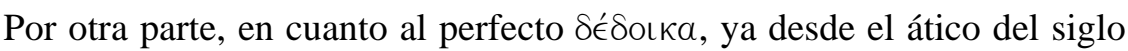
IV a. C., comenzó a desarrollarse una flexión en singular semejante a las

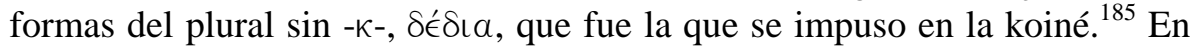
las Cartas, en este caso, se usan esas formas antiguas (13.3, $\delta \epsilon ́ \delta о เ \kappa \alpha)$, que Filóstrato en su obra mantiene de forma general. ${ }^{186}$

181 Si bien algunas construcciones características del ático solían conservar doble tau en todos los niveles, vid. L. Radermacher, 1925, p. 46, y 1947, pp. 20 s.; A. Meillet, 1975, pp. 279 s. y 312; F. Blass \& A. Debrunner \& F. Rehkopf, 1979, pp. 27 s.

182 Vid. W. Schmid, 1964b, pp. 83 ss., 1964c, pp. 15 ss., 1964d, pp. 14 y 579; G. Horrocks, 1997, p. 83.

183 Vid. W. Schmid, 1964d, pp. 13 y 579; G. Horrocks, 1997, pp. 83 s.

184 Vid. E. Schwyzer, 1968, pp. 666 y 755; A. López Eire, 1991, pp. 97 s.

185 Vid. E. Schwyzer, 1968, p. 769.

186 Vid. E. Schmid, 1964d, pp. 33 s. y 601 s. 
En griego existen diversas posibilidades para la expresión de la posesión: los pronombres posesivos se corresponderían con el nivel literario de la lengua desde antiguo, ${ }^{187}$ mientras que el uso del pronombre personal en genitivo es propio de documentos ajenos a la literatura, y será el medio que la koiné adopte para la expresión de la posesión. En la selección de nuestras Cartas aparecen ambos, ${ }^{188}$ además de las formas compactas propias del ático para la posesión reflexiva, si bien estas se utilizaban también en la koiné, ${ }^{189}$ a diferencia del dativo, que habrá desaparecido y sólo se mantendrá a nivel literario. ${ }^{190}$

A lo largo de la koiné tiene lugar la desaparición del optativo, pero tanto las fuentes más vulgares como las de elevado nivel literario lo conservan en cierta medida largo tiempo, ${ }^{191}$ si bien es cierto que estas últimas se preocuparán de utilizarlo correcta y repetidamente para alejarse de esa lengua común y acercarse a la antigua y dorada época clásica ática. Nuestra selección de Cartas muestra algún ejemplo, pero usa este modo de forma muy escasa, si bien lo hace conforme a las reglas áticass ${ }^{192}$ (véase 14.2,

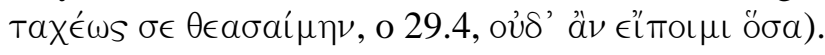

Si pasamos a la cuestión léxica, en la koiné la forma vav̂s fue sustituida por la voz $\pi$ तoîov, de flexión mucho más sencilla. ${ }^{193}$ En el ámbito literario se mantuvo vav̂s, si bien los aticistas utilizaban la flexión ática y la jónica, ${ }^{194}$ aunque los ejemplos que nos remiten las Cartas corresponden a formas

187 Vid. J. Humbert, 1960, pp. 60 s. y 64; E. Schwyzer \& A. Debrunner, 1966, pp. 147 s. y 200 ss.

188 Adjetivos posesivos en 26.3, 29.1 y 59.4; genitivo de los pronombres personales en 12.1, 25.4, 28.3 y 29.1.

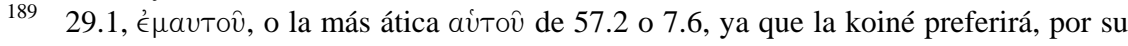
mayor claridad, las formas sin contraer éavT-.

190 E. Schwyzer \& A. Debrunner, 1966, pp. 147 s.

191 De hecho esa desaparición comienza a producirse en los orígenes de la koiné a partir del ático, vid. A. López Eire, 1991, pp. 77 ss.

192 El optativo desiderativo todavía se empleaba en la lengua coloquial, aunque en algunas fuentes (Nuevo testamento) se observa una marcada tendencia al uso del imperativo en estos contextos: vid. L. Radermacher, 1925, pp. 160 y 164; E. Mayser, 1970b, pp. 289 ss.; F. Blass \& A. Debrunner \& F. Rehkopf, 1979, pp. 311 s. En cuanto al optativo potencial en oración principal, es uno de los usos que más tiempo se conservó y aparece normalmente empleado de forma correcta en todos los tipos de fuentes.

193 Vid. E. Mayser, 1970a, p. 28; A. Meillet, 1975, p. 301; F. Blass \& A. Debrunner \& F. Rehkopf, 1979, pp. 38 s.; A. López Eire, 1991, pp. 15 s.

194 E. Schmid, 1964a, p. 48, 1964c, pp. 28 s., 1964d, pp. 23 y 585 s. 
áticas, $47.1 \nu \in \omega ́ s, 16.4 \nu \eta \hat{\eta} \in S$, coincidiendo, por lo tanto, con ese nivel elevado de carácter literario llamado aticismo. Otro término que acabó siendo sustituido durante la génesis y desarrollo de la koiné fue ov̂s (y también ن̂s), y en su lugar se prefirió xoîpos. En una de las Cartas de nuestra selección Filóstrato utiliza el antiguo término ov̂s, alejándose, de este modo, de la lengua coloquial. ${ }^{195}$

A través de estos ejemplos podemos hacernos una idea del tipo de lengua empleada por Filóstrato, al menos en este tipo de Cartas. El cuidado por la corrección y el uso de claros elementos de raigambre aticista es evidente, pero también lo es cierta cercanía a la lengua coloquial, ${ }^{196}$ de modo que en buena media nos acercamos a la definición que veíamos en la Carta a Aspasio de Ravena acerca de la lengua más apropiada para la escritura de cartas.

Otro elemento favorable a la claridad es la repetición, ${ }^{197}$ y las ventajas de su uso -evita la ambigüedad y confiere viveza- ${ }^{198}$ subordinan el principio de la brevedad que la teoría retórica impone a la composición epistolar. Son variados los medios que encontraremos utilizados en las Cartas, como la anáfora o epanáfora, ${ }^{199}$ de la que podemos ver un buen ejemplo en la Carta $6:^{200}$

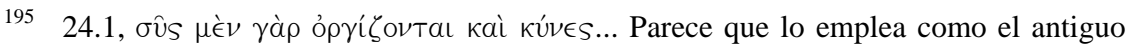
nominativo plural ático (en lugar del más habitual $\sigma u ́ \in S$ ), siguiendo un estilo aticista puro, si bien en este punto los manuscritos varían y algunos escriben ó $\rho \gamma i ́ \zeta \epsilon$ ta , de modo que sería бûs simplemente nominativo singular. En esta cuestión volvemos a estar a merced de la transmisión textual.

196 Puede destacarse la doble sigma junto a la doble tau, el uso de $\epsilon$ á $\nu$ y ảv, escasez de optativos, o ausencia de duales.

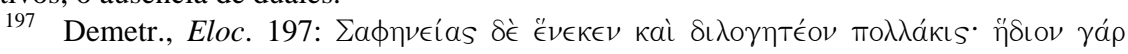

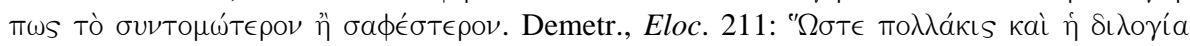

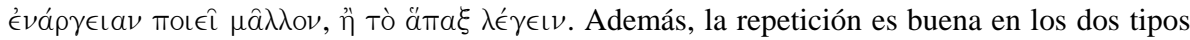
de estilo que han de mezclarse en el género epistolar, el simple y el elegante (Demetr., Eloc. 140, 141 y 196).

198 Vid. el ejemplo que Demetrio proporciona, cuya concisión acarrearía la pérdida del

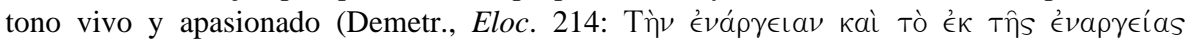
та́ंos).

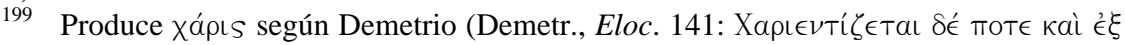

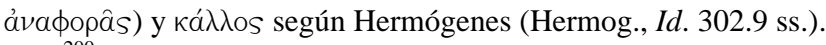

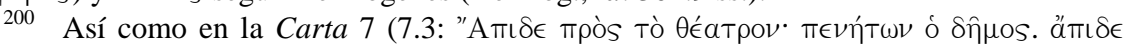

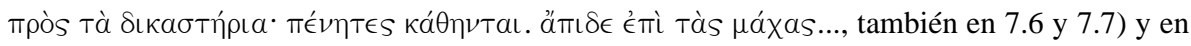
otras muchas: 5.1, 12.1, 12.3, 14.2, 16.2, 16.4, 16.5, 23.1, 24.2, 25.2, 26.1, 26.2, 28.3, 29.1, 


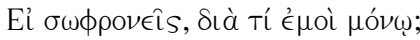

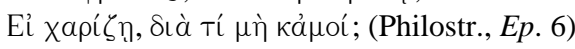

Asimismo pueden repetirse principios y finales de palabras, ${ }^{201}$ como en

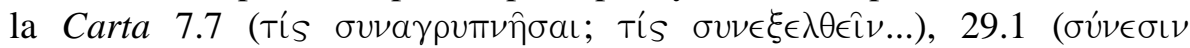

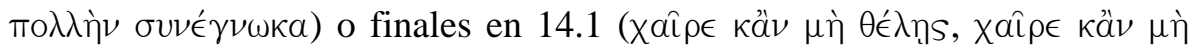

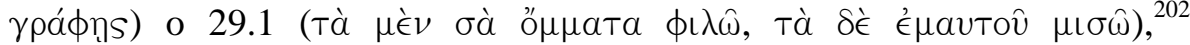
repetición que recibe el nombre de epífora o antístrofe cuando se produce al final de los miembros. ${ }^{203}$

Otra forma de repetición consiste en utilizar el final de un miembro o frase al principio del siguiente, que en las obras de retórica se llama anadiplosis, reduplicación o anástrofe ${ }^{204}$ y que podemos ver en la Carta 29.2

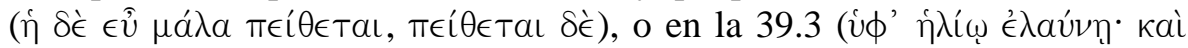

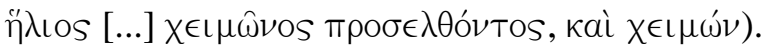

El uso de poliptoton (o traductio), que consiste en la repetición de un término clave bajo distintas formas, dice Hermógenes que produce belleza si

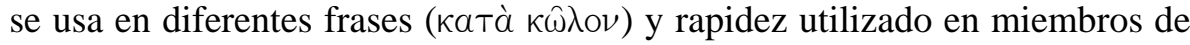

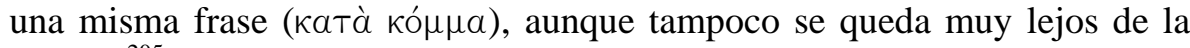
belleza. ${ }^{205}$ Así se produce poliptoton en la Carta 7 de los términos Tév $\eta$ s y $\pi \lambda$ ov́øıos, como es natural dado el tema, aunque también destaca la

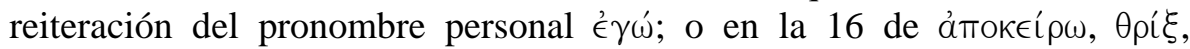

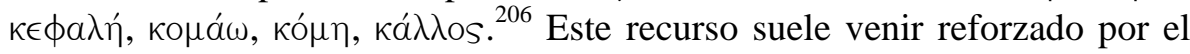
uso de la derivatio, y, de este modo, encontramos palabras de la misma raíz,

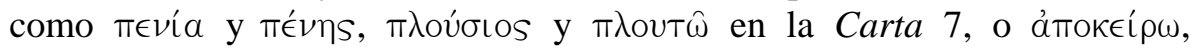

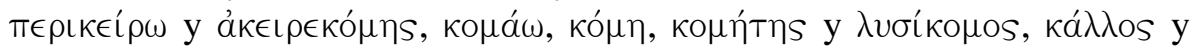
кa入ós en la 16.

29. 4, 39.2, 50.1, 59.4 y 61.3. Puede observarse, además, que muchas de las Cartas utilizan reiteradamente este recurso.

201 Vid. Hermog., Id. 302.2 ss.

202 Más ejemplos en 16.5 o 25.4, etc.

203 Según Hermógenes produce кá $\lambda$ os (Hermog., Id. 303.6 ss.). Vid. J. D. Denniston, 2000, pp. 87 ss.

204 Hermog., Id. 304.15 ss.

205 Hermog., Id. 306.13 ss. y 306.18 ss.; Longin. 23.1.

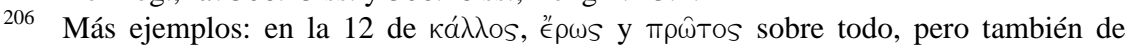

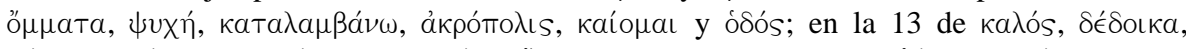

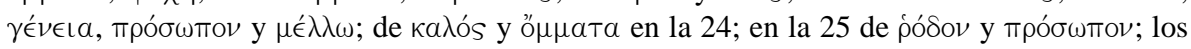

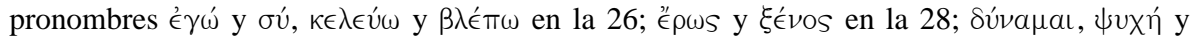

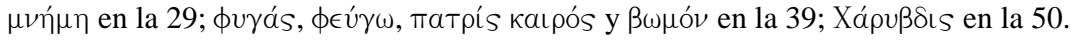


Otro de los elementos clave para el estilo epistolar, según Demetrio, consiste en moderar la extensión y el estilo, para evitar que la carta se convierta en un tratado: ${ }^{207}$

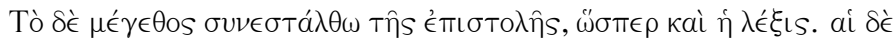

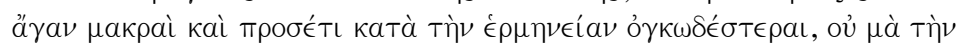

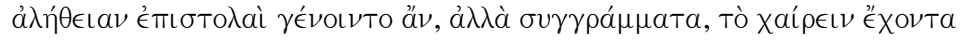

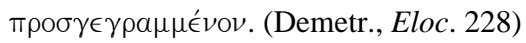

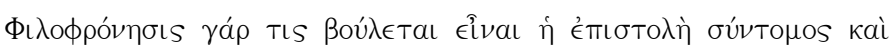

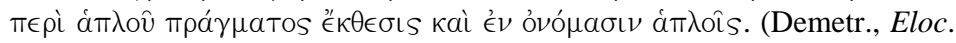
231)

Además, la brevedad puede poseer xápıs, otra de las cualidades que la composición de cartas ha de poseer. ${ }^{208} \mathrm{Y}$ si bien los manuales recomiendan, por una parte, el uso de enumeraciones, acumulaciones y gradaciones, ${ }^{209}$ asimismo advierten de que produce un mayor impacto sobre la audiencia un resumen claro de los asuntos más terribles, dado que tratar de explicar todo al detalle impide la compasión, y por ello se aconseja como la mejor proporción una medida intermedia (Aps., Rh. 31). Por otra parte, también aconsejaba la teoría el uso de la repetición en aras de una mayor claridad, lo que parece contradecir el principio de la concisión, por lo que Demetrio propone, para el estilo simple, el empleo de miembros breves y no prolongar la extensión de los períodos; ${ }^{210}$ y es que para producir má $\theta$ os son también más útiles las expresiones breves, ${ }^{211} \mathrm{y}$ en la composición de etopeyas

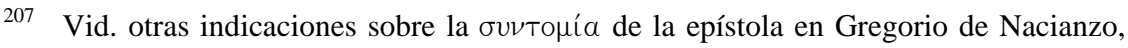

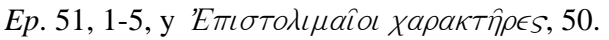

${ }^{208}$ Vid. Demetr., Eloc. 235 (en una carta deben mezclarse el estilo sencillo y el gracioso)

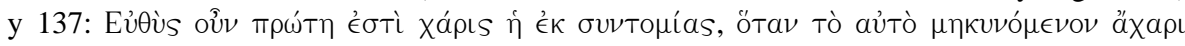

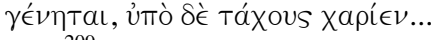

209 Vid., sobre todo, los apartados dedicados a la creación de má $\theta$ os y este mismo sobre el estilo apropiado.

210 Demetr., Eloc. 202-206. La composición no debe resultar trabada y pomposa como la de las Cartas de Platón y Tucídides (Demetr., Eloc. 228 s.). Tampoco la Carta a Aspasio de Ravena considera apropiados los períodos para el estilo epistolar (Philostr., Dial. 1, 257 s.).

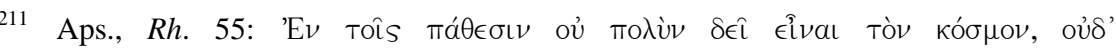

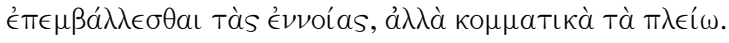


asimismo se aconseja una distribución en miembros breves, ${ }^{212}$ con los que se consigue un estilo puro, claro, bello y conciso. ${ }^{213}$

De este modo tenemos, por un lado, desde unas Cartas con extensión bastante sucinta, como algún billetito considerablemente breve (dos líneas ocupa en nuestra selección ${ }^{214}$ la Carta 6 ) hasta tres $\operatorname{Cartas}(7,16,28)$ un poco más amplias pero siempre dentro de unos límites muy moderados (la más extensa, la Carta 7, ocupa treinta y seis líneas). Por otro lado, aunque algunas oraciones de nuestras Cartas tienen cierta dimensión, no llegan siquiera a constituir auténticos períodos: puede comprobarse en las Cartas 11.3, 16.6, 28.2 y 61.3. Sin embargo, abundan las frases o miembros breves en todo el epistolario; sirvan de ejemplo pasajes de las mismas Cartas que acabamos de citar: 11.2, 16.2, 16.4, 16.5, 28.3 y 61.1-2.

La distribución de un tamaño similar a los $\kappa \hat{\omega} \lambda a$ les confiere igualmente belleza (Hermog., Id. 305.13 ss.), un recurso que no es ajeno al autor de las Cartas. Valga de ejemplo la isocolía de los miembros de la Carta 6 antes citada (cuatro sílabas más siete y cuatro más seis); también la 12.1 (тaxéws

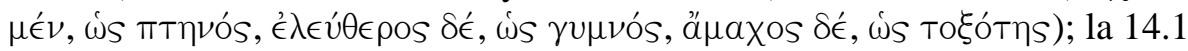

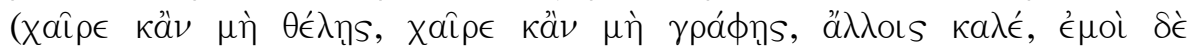
ن் 61.3.

La construcción sintáctica se ve afectada, según Demetrio, por las necesidades propias de la composición epistolar, puesto que, además de su

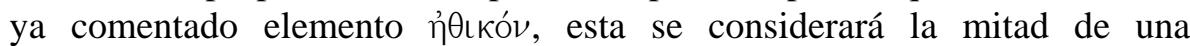
conversación, ${ }^{215}$ por lo que ya Artemón aconsejaba escribir una carta del

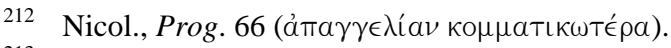

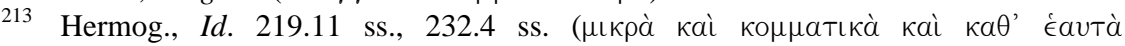

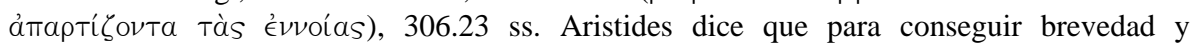
concisión no deben utilizarse perífrasis, sino más bien una expresión directa, Aristid., $R h$. I

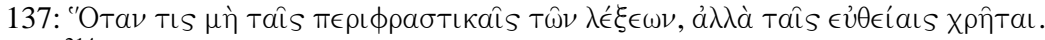

214 Véase el Anexo final.

215 Sobre la Carta como mitad de una conversación, vid. F. X. J. Exler, 1923, p. 15; K. Thraede, 1970, p. 126; W. Schadewaldt, 1973, p. 32; E. Suárez de la Torre, 1979, pp. 37 s.; J. G. Altman, 1982, pp. 135 ss.; P. Cugusi, 1990, p. 383; R. J. Gallé Cejudo, 1994-1995, pp. 41 ss., y 1999, pp. 22 y 42 ss. E. Suárez de la Torre identifica los conceptos más representativos de la Lingüística estructural en la epistolografía: «el esquema tradicional de los factores del lenguaje (hablante, tema o mensaje y oyente) pueden ser traspasados perfectamente considerando el carácter lineal de la esquematización de la Carta sobre los términos emisor mensaje (con código) - receptor», E. Suárez de la Torre, 1979, p. 21; y R. J. Gallé Cejudo, 
mismo modo que un diálogo ${ }^{216}$ (Demetr., Eloc. 223). Sin embargo, nos advierte Demetrio, no son apropiadas en este ámbito las oraciones inconexas características del diálogo ni el estilo propio de un actor (Demetr., Eloc. 193 ss. y 226). Nuestras Cartas no cometen esos excesos que Sobre el estilo denuncia, pero manifiestan evidentes signos característicos del diálogo, ${ }^{217}$ como el uso frecuente del vocativo para interpelar a sus amados (5.1,

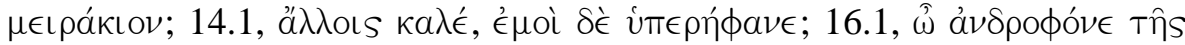

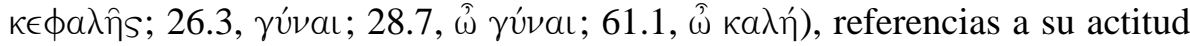
o hechos (5.1, 6, 7.1, 11.1, 11.2, 13.2, 13.3, 23.1 y 59.2), preguntas (5.1, 7.7, 11.1, 16.2, 16.3, 23.2, 26.1, 59.4, 61.1 y 61.3), respuestas (39.1 y 12.1), advertencias (28.4), consejos (23.1), órdenes (5.1, 5.2, 7.3, 7.4, 12.3, 13.1, 13.4, 16.8, 23.2, 24.2, 25.1, 25.4, 39.1 y 61.3), ruegos (26.1, 26.3, 28.3, 28.7, 29.4 y 39.5), maldiciones (14.2), promesas (13.4 y 59.4), exclamaciones (12.4 y 61.1-2), etc. ${ }^{218}$ Todos estos elementos son propios de un estilo sincero y espontáneo que Hermógenes nos describe en su obra Sobre las formas de estilo. ${ }^{219}$

1994-1995, p. 42, hace referencia al fenómeno epistolar como uno de «dialogismo»: «definido como un proceso de comunicación caracterizado por la presencia de dos sujetos, uno de los cuales puede permanecer latente, estar a distancia, ser un ente de ficción, etc., donde basta con que el emisor actúe con la idea de que otro va a entrar en el proceso para decodificar su discurso».

216 Demetr., Eloc. 223. También la etopeya se considera apropiada para el desarrollo del diálogo (Theo p. 60).

217 Aparentemente estos medios desdibujan en la epistolografía ficticia la comunicación epistolar, vid. sobre ellos R. J. Gallé Cejudo, 1997, pp. 217 ss., quien destaca de los autores de epistolografía ficticia griega que «observan de forma rigurosa la definición antigua de la

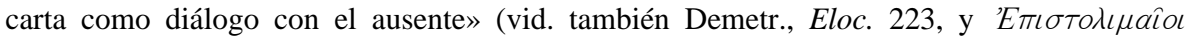
$\chi a \rho a \chi \tau \hat{\eta} \rho \in S$, p. 14). Con frecuencia se considera que el uso de rasgos propios del diálogo rompe la verosimilitud epistolar: vid. P. A. Rosenmeyer, 2001, pp. 330 ss.; en opinión de J. Elsner, 2009, p. 9, la intromisión de otros géneros retóricos en las Cartas «demolish its specific form and imaginary structure as the single voice of one participant in a relationship to others». Sin embargo, ya se ha comentado, es propio del género epistolar esta capacidad de absorber rasgos de otros géneros literarios (vid. E. Suárez de la Torre, 1988).

218 Acerca de otro tipo de expresiones propias del diálogo como invocaciones, manifestación de sorpresa, aporías, reproducción de discursos imaginarios, etc., vid. supra, especialmente el apartado dedicado al estudio del má $\theta$ os.

219 Vid. Hermog., Id. 352.15 ss.: quejas (352.23 ss.), ruegos (353.16 ss.), manifestación de sorpresa (355.2 ss.), respuestas (356.18 ss.), invocaciones (360.13 ss.), preguntas (360.15 ss.), aporías (361.4 ss.). 
Volviendo a la sintaxis adecuada para la composición epistolar, por un lado, Sobre el estilo no recomienda el uso del asíndeton, ${ }^{220}$ puesto que resta claridad al estilo simple y no es propio de la epistolografía. Y, por su parte, nos indica Apsines que el uso de marcas de separación realza el tema de que se habla. ${ }^{221}$ Así encontramos un empleo especial de nexos en la Carta 25, cuyo segundo parágrafo consta de varios miembros precedidos todos por

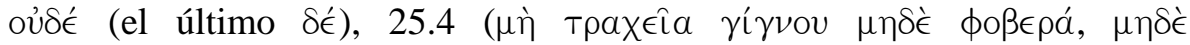

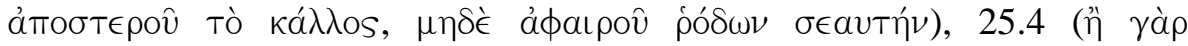

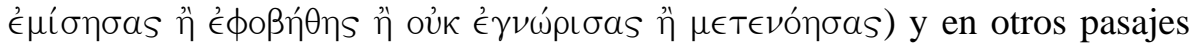
de las Cartas 16.4, 16.7, 24.1, 28.2, 28.3, 29.3, 29.4 y 59.1. Sin embargo, la retórica antigua aconsejaba el uso del asíndeton para favorecer la comunicación de emociones, ${ }^{222}$ a cuya expresión proporciona continuidad, ${ }^{223}$ y el propio Filóstrato consideraba que concedía esplendor al estilo epistolar. ${ }^{224}$ En la Carta 50 no encontramos oraciones inconexas propias del diálogo (las que tanto temía Demetrio en sus indicaciones), pero se prescinde en gran medida de nexos de unión que confieren a su estilo esa rapidez y viveza propias de las emociones (cf. Aps., $R h$. 48). Dada la carga emotiva que el autor pretende plasmar en la temática de estas Cartas, es normal una acentuación en el uso de este recurso en detrimento de la deseada sencillez y claridad característica del estilo epistolar, si bien en ningún caso se limita la comprensión del texto, sino que simplemente se confiere vigor y fuerza al má$\theta$ os. Además, fruto de la ejercitación retórica que hemos ido observando en estas composiciones, no es raro que haga uso Filóstrato del asíndeton en las situaciones similares que escribe para sendos destinatarios femeninos y

220 Vid. Demetr. 192 s. y 226.

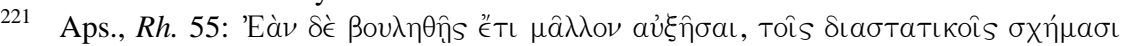

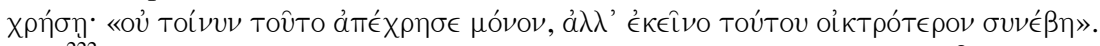

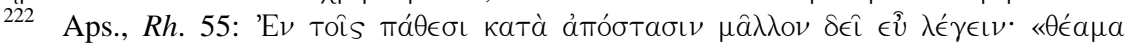
$\delta \in \iota \nu$ ó,$\hat{\omega} \gamma \hat{\eta} »$.

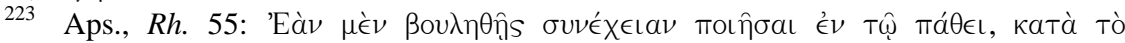

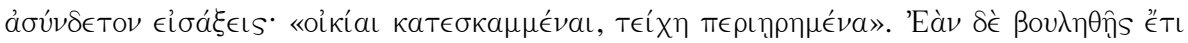

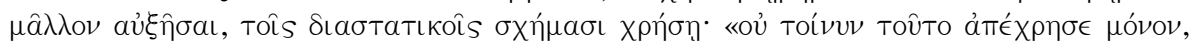

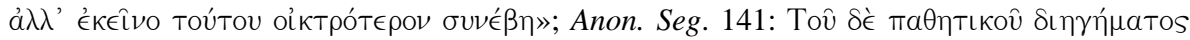

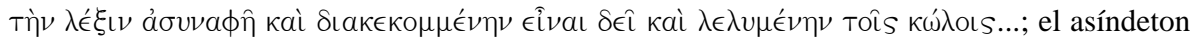
lo recomendaba el autor de $\Pi \epsilon \rho i$ ú $\psi o u s$ para no perder el vigor y la fuerza de la emoción, vid. Longin. 19 y 21.1-2.

224 Filóstrato aprueba el asíndeton (además de la claridad y la concisión) del estilo

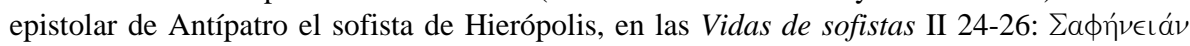

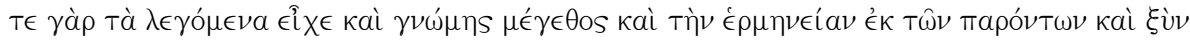

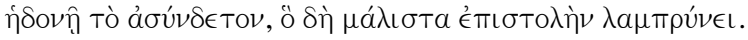

Monografías de Filología Griega 20. ISSN 1136-0860 
masculinos, y, así, las Cartas 5 y 47 emplean este recurso especialmente al final:

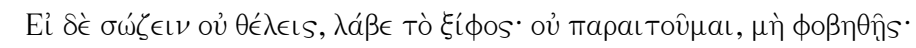

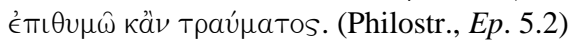

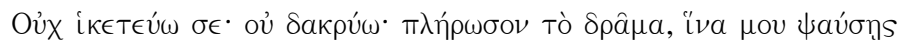

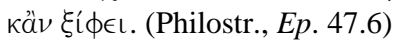

De forma similar las parejas 7 y 23 ( 7.7 y 23.2, aunque también se usa asíndeton en 7.3 y 7.4), 16.8 y 61.3, y también en otras de forma independiente, como la 14.1, 16.5 o 24.2-3.

Para finalizar haremos referencia a los temas que la preceptiva antigua consideraba adecuados para la epistolografía, y es que en ella, según Demetrio, ${ }^{225}$ no tienen cabida los asuntos lógicos o científicos. Son los temas simples los propios del estilo i $\sigma \times v o ́ s,{ }^{226}$ que en la composición de cartas debe mezclarse con el $x a \rho i \in \in S_{S},{ }^{227}$ y las $\chi \alpha ́ \rho ı t \in S$, características del estilo elegante, residen en determinadas temáticas, como la de los amores. ${ }^{228}$ Todos los argumentos de tipo amoroso son normalmente dulces, nos indica

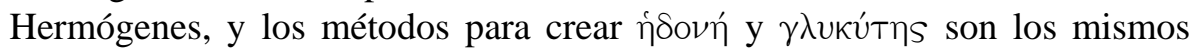

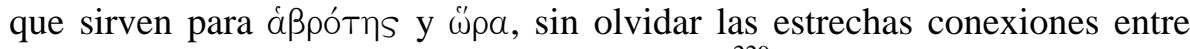
estas formas y los estilos simple, claro y bello. ${ }^{229}$ Algunos de los contenidos dulces y placenteros que destaca Hermógenes son aquellos relacionados con la mitología, como hemos visto con frecuencia en nuestra selección de Cartas, ${ }^{230}$ pero tienen el mismo efecto las historias cercanas a los mitos y también aquellas que contienen elementos próximos al mito pero son más creíbles, ${ }^{231}$ entre las que podemos contar todas las referencias a ese pasado

225 Demetr., Eloc. 230 s.

226 Demetr., Eloc. 190. Los manuales de retórica exigen también temas sencillos, comunes y ordinarios para un estilo simple y claro, vid. Hermog., Id. 227.1 ss. y 322.4 ss. (esos temas comunes y conocidos por todos son característicos de la pureza y, a su vez, de la claridad, y son los mismos que producen simplicidad), y Aristid., Rh. II 3.

227 Demetr., Eloc., 235.

228 Junto a los jardines de ninfas, los cantos de himeneo, y todos los que recoge la poesía de Safo o Hiponacte; vid. Demetr., Eloc. 132 ss. y 163.

229 Vid. Hermog., Id. 298.20 ss., 329.20 ss., 333.4 ss., 335.24 s., 336.1 ss., 339 y 344.13 ss., y también Demetr., Eloc. 157 s., Aristid., Rh. I 132.

230 Sobre los temas en general de las Cartas de Filóstrato, vid. E. Suárez de la Torre, 1991, pp. 113 ss.; S. Follet, 2002, pp. 248 s.

231 El ejemplo de Hermógenes para este último tipo son las narraciones que pueden leerse en la obra de Heródoto, Hermog., Id. 219.2 s., 330.1 ss., 330.18 ss. y 333.9 ss. 
glorioso que los autores de la Segunda Sofística pretenden rememorar en sus escritos, sobre todo en relación con Atenas. Piénsese, por ejemplo, en todos los personajes a que hace referencia, Sócrates, Alcibíades, Arístides, Temístocles, Jenofonte, o las figuras de Harmodio y Aristogitón. ${ }^{232}$

Desde una perspectiva práctica podemos constatar la coincidencia de los temas tratados en esta selección de Cartas eróticas con los distintos

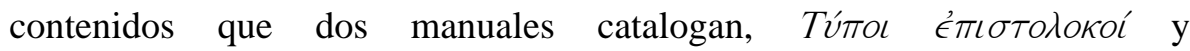

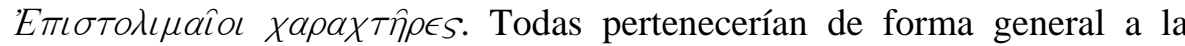

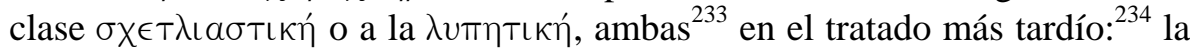
primera expresa queja y lamento; la segunda, pena y aflicción. Pero también

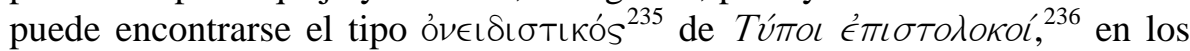
reproches y acusaciones que se lanzan (como la Carta 48), $\psi \in \kappa$ K LKós $^{237}$ (en los vituperios de la 50), є́mı frecuentes peticiones que se realizan en las Cartas 12, 24, 25, 26, 28, 29 y

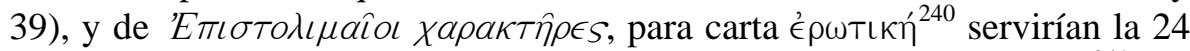
y 25, que lamentan un enfado (cabría también en la clase $\theta \epsilon \rho a \pi \epsilon \cup \tau \iota \kappa \eta^{241}$ por ello), pero demuestran el amor que se siente por el destinatario.

232 Cuyo interés como tiranicidas ha desaparecido en las referencias filostrateas para ceder protagonismo a su relación erótica.

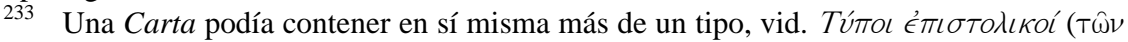

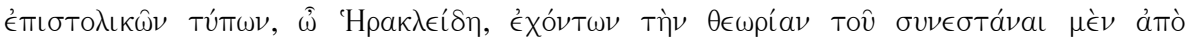

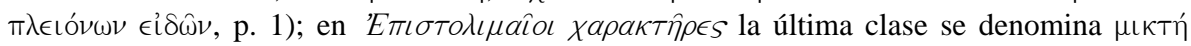
porque una Carta puede componerse de varios tipos (pp. 19 y 33).

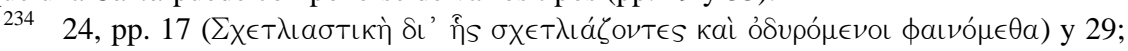

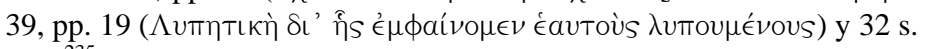

235 4, p. 4.

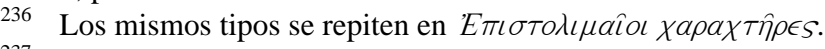

237 9, p. 6.

238 6, p. 5 .

239 12, p. 7

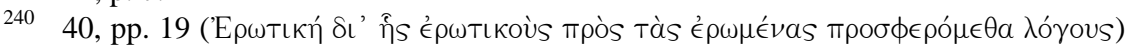
y 33.

241 15, pp. 16 s. y 26.

Monografías de Filología Griega 20. ISSN 1136-0860 
A través del pormenorizado análisis realizado no queremos decir que estos textos sean calcos clavados de la exposición teórica, dado que se reconoce en las Cartas de Filóstrato la elaboración literaria del autor, sino que el aprendizaje de la disciplina retórica y su ejercitación en la escuela hacen que los autores conciban sus composiciones irremediablemente influidos por esas normas no solo aprendidas, sino enseñadas como indispensables para el acto literario. No debe olvidarse, además, que Filóstrato recibió una amplia formación retórica en varios centros y también se dedicó a la enseñanza.

Si bien no tenemos constancia de que el autor siguiera directamente los textos que aquí hemos comparado, el análisis se ha basado en la idea de que en sus composiciones influirían, si no estos mismos preceptos teóricos, otros similares que seguirían la misma corriente retórica. Y, como muestra de ello, tenemos la similitud entre los manuales de Progymnasmata, a pesar de la distancia temporal y geográfica que los separa. Además, el uso del mismo recurso en situaciones similares (asíndeton al final de las Cartas en parejas como 5 y 47, 7 y 23, 16 y 61; invocaciones en la 5 y 47, 16 y 61, 26 y 57; comparaciones con animales y plantas en la 24 y 25, etc.) nos indica cierta sistematicidad a la hora de componer las Cartas. También hemos visto cómo los recursos relativos a la expresión del lamento son más frecuentes o propios de nuestra selección (como el elevado número de comparaciones, el

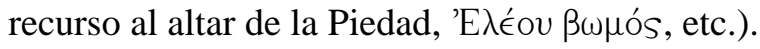

Una de las cuestiones que más preocupa a la crítica reside en la conservación o ruptura de la ficción epistolar en los documentos protagonistas de este estudio. ${ }^{242}$ Tanto la ausencia de remitente y destinatario definidos $^{243}$ como la falta de determinadas marcas formales de la epistolografía y el uso de rasgos considerados propios de otros géneros ${ }^{244}$ conducen a muchos estudiosos a dudar del género al que atribuir estos

242 Téngase en cuenta, por otra parte, que en la Antigüedad estas composiciones se reconocían plenamente como epistolografía y que los autores no sentían la necesidad de cuidar escrupulosamente unas formas que se daban por sabidas (cf. R. J. Gallé Cejudo, 1997, p. 224).

243 En otras Cartas de la colección que no se han incluido en este estudio sí que aparecen los destinatarios.

244 Estas características llevan a S. Goldhill, 2009, pp. 297 y 305, a considerar la colección completa «a sort of handbook or manual for the desiring subject» $\mathrm{y}$ a destacar su valor didáctico («they teach you how to speak the role of the educated lover», p. 297). 
textos, ${ }^{245}$ si bien no debe desdeñarse la suposición de que probablemente al autor le interesaba más el contenido mismo de las Cartas que moldearlas en un formato epistolar estricto. Es cierto que esos aspectos «epistolares» se encuentran en menor medida en Filóstrato que en los anteriores testimonios que tenemos de epistolografía erótico-amorosa, Alcifrón y Eliano. Sin embargo, no debe olvidarse que varias de las Cartas de estos autores, aunque tengan casi todas remitente y destinatario, carecen de esas marcas como saludo, despedida y otros tópicos epistolares y contienen, como mucho, una segunda persona del singular (por ejemplo, Alciphr. I 18, I 19, III 3, III 6, IV 10, etc.; Ael., Ep. 1, 3, 4, 6) y a veces ni siquiera ese indicio (Alciphr. I 1, I 13, I 15, II 1, II 4, III 2, etc.; Ael., Ep. 5). De este modo, la única diferencia con nuestras Cartas sería la mención del remitente y del destinatario. En cambio, debe destacarse que las colecciones de Alcifrón y de Eliano poseen intercambios epistolares (Alciphr. I 11-12, I 17-18, II 6-7, II 15-16, IV 8-9, IV 18-19; Ael., Ep. 7 y 8; 11 y 12; 13, 14, 15 y 16) y que muchas de sus Cartas hacen referencia a su ubicación en un contexto ateniense, aunque alguna carece de esa información (Alciphr. II 1; Ael., Ep. 4, 5, 6, 7, etc.). Puede decirse que las tres colecciones ofrecen pequeños recortes de la Antigüedad, pero las dos primeras contienen ubicaciones y contextos más precisos que los de esta última.

Mucho se ha hablado de la ruptura de la ficción epistolar también merced a la llamada «intromisión» del diálogo en las Cartas de Filóstrato. Sin embargo, ya se ha visto que es un rasgo que la preceptiva epistolar de la Antigüedad consideraba propio de este género, pero es que, además, refuerza, en nuestra opinión, el reflejo de la relación íntima entre dos personas distanciadas espacial o temporalmente, dado el carácter de cercanía que ese recurso imprime.

245 Y así, con frecuencia se considera que en las Cartas de Filóstrato el género epistolar está difuminado o quebrantado, sobre todo cuando se establece que dicho género consiste en una narrativa de intercambio, o cuando se busca una relación interna entre los elementos que componen una colección epistolar y que le confiera sentido como tal (vid. P. A. Rosenmeyer, 2001, p. 237; S. Goldhill, 2009, pp. 287 y 295); sin embargo, no se rompe esta ficción, sino que las formas y objetivos de la colección difieren de otras más conocidas, si bien los destinatarios finales de cualquier colección ficticia serán siempre los lectores reales. Además, no es necesaria la existencia o respuesta expresa de un destinatario ficticio, sino que con solo imaginarlo ya se mantiene la ficción epistolar. En todo caso no deben olvidarse los problemas que existen en cuanto a la génesis de este corpus epistolar, y la posibilidad de autoría múltiple, lo que dificulta a veces un análisis global de la producción epistolar filostratea. 
Todo ello en cierta medida nos induce, por una parte, a considerar los escritos filostrateos más cercanos a la elaboración escolar o a la ejercitación de unos tópicos, si bien debe reconocerse igualmente la elevada composición literaria tanto desde el punto de vista de la forma como del contenido. Igualmente parece llevarnos a esa conclusión el desarrollo de la misma temática con sendos destinatarios, masculinos y femeninos, y también la exposición de diferentes conductas y actitudes respecto de un tema. Por otra parte, la falta de remitentes y destinatarios puede atribuirse a una deseada intemporalidad para los mismos, puesto que, cualquiera que sea la época o procedencia del lector real, es este último el que importa a Filóstrato, el lector en primera persona de sus epístolas y también el destinatario de la forma y contenido de las mismas. Quizá por ello tampoco sintió la necesidad de ofrecer una ubicación como Atenas o un siglo concreto, sino que erige todo ese pasado glorioso únicamente griego como ejemplo y modelo para la posteridad. En ese caso, aunque su proximidad a la teoría retórica sigue siendo evidente, sus objetivos no se habrían detenido en la simple puesta en práctica de una preceptiva aprendida, sino que se habrían consumado en esa forma aparentemente vaga e imprecisa que suele atribuirse a nuestras Cartas, que les confiere en realidad un carácter intemporal y trascendental. Por ello, si bien la prosa de Filóstrato es menos personal o directa que la de Alcifrón o Eliano, resulta, por otra parte, más poética y utiliza la obra literaria como excusa para exhibir sus conocimientos. ${ }^{246} \mathrm{Y}$ así, no es muy habitual la expresión del sufrimiento de forma personal, sino que suele hacerse a través de ejemplos, normalmente del glorioso pasado heleno, que pueden considerarse muestras de la independencia literaria y cultural del pueblo griego respecto de su gobernante Roma, además de corresponderse con el necesario alarde y ostentación de ese pasado dorado que fluía en el movimiento de la Segunda Sofística. ${ }^{247}$ Entonces, tanto si, por una parte, se interpretan estas Cartas como textos cercanos a la composición escolar, como si, por otra, se consideran una obra más acabada pero caracterizada por

246 Los lectores modernos consideran con frecuencia que estas cartas adolecen de la función comunicativa epistolar y de la expresión de sentimiento amoroso sincero (vid. P. A. Rosenmeyer, 2001, p. 325, quien las califica de «poetic showpieces»), pero es preciso tener en cuenta el ámbito en el que se generaron estas epístolas y las intenciones del autor, para el que esta sería la manera en que una persona cultivada debería poder manifestar sus sentimientos a sus seres queridos, que los comprenderían perfectamente y no esperarían otro tipo de epistolografía amorosa.

247 La aparente trivialidad de sus obras no debe ocultar el serio propósito que esconden, nos advierte S. Swain sobre la producción filostratea (vid. S. Swain, 2009, p. 37). 
unos objetivos diferentes, trascendentales en este caso, hemos de pensar también en el deseo de mantener vivas esas legendarias raíces a través de la enseñanza y de la obra literaria. 
ANEXO

MAL de AMORES EN LAS CARTAS ERÓTICAS de FILÓSTRATO

Selección de Cartas 



\section{INTRODUCCIÓN}

La existencia de dos familias de manuscritos que recogen sendas versiones de las Cartas de Filóstrato impulsó a C. L. Kayser a considerar que ambas procedían de la mano del autor, siendo la más breve de ellas la más antigua y original -familia 1 o «melior familia»- y, por lo tanto, la que contenía el mejor y más fiable texto, mientras que la otra, con adiciones diversas, procedía de una reelaboración tardía del propio Filóstrato -familia 2 o «deterior familia»-, estimada por C. L. Kayser de peor calidad. ${ }^{248} \mathrm{Y}$ de ese modo, en su edición, C. L. Kayser coloca los «añadidos» de ese segundo grupo a pie de página, mientras que su texto de las Cartas consta básicamente de lo transmitido en la familia 1 de manuscritos. ${ }^{249}$ Ediciones posteriores seguirán esta interpretación: A. Westermann, 1878 (=1849), convencido de la validez de esa propuesta; y, manifestando su desacuerdo, R. Hercher, $1873,{ }^{250}$ que se vio obligado a seguir las innovaciones propuestas por C. L. Kayser repitiendo casi completamente el texto de A. Westermann. Sin embargo, las ediciones anteriores no establecían tal segregación y publicaban la versión extensa de las Cartas. La edición de G. Olearius (G. Öhlschläger), 1709, reunía por vez primera la colección completa del corpus de cartas eróticas de Filóstrato, ${ }^{251}$ a la que precede la llamada Carta a Aspasio de Ravena, posteriormente clasificada como $\delta\left\llcorner a ́ \lambda \epsilon \xi_{\iota s}\right.$ en lugar de epístola y que actualmente se atribuye al llamado

248 Vid. C. L. Kayser, 1844, pp. I ss. del proemio que precede al texto de las Cartas.

249 Sobre los manuscritos que empleó vid. C. L. Kayser, 1844, pp. II ss. del proemio que introduce la edición de las Cartas; vid. también, sobre estos manuscritos empleados por C. L. Kayser, las páginas que detallan A. R. Benner \& F. H. Fobes, 1962, pp. 394 ss.

250 R. Hercher, 1873, p. LIX.

251 Acerca de la reunión de las distintas Cartas que han acabado componiendo la colección filostratea, vid. G. Olearius, 1709, pp. 911 ss. (reproducido en J. F. Boissonade, 1842, pp. vi ss.); C. L. Kayser, 1844, pp. II ss.; A. R. Benner \& F. H. Fobes, 1962, pp. 397 ss. y 404. 
Filóstrato de Lemnos. ${ }^{252}$ En 1842 publicó J. F. Boissonade una edición de las Cartas con comentario, en la que reproduce el prefacio de G. Olearius y parte de sus anotaciones al texto, para el que realiza una nueva colación de algunos manuscritos.

Pronto se alzaron voces contra la propuesta de C. L. Kayser, como la ya citada de R. Hercher, o K. Münscher, que rebate sus argumentos y considera más cercana a la obra original la llamada segunda familia de manuscritos, mientras que las Cartas abreviadas serían el resultado de la mano de un editor posterior. ${ }^{253}$ Más tarde F. Solmsen atribuirá la existencia de las dos versiones a la publicación de sendas antologías posteriores a Filóstrato, en las que los distintos criterios de edición hicieron que una mantuviera un texto próximo al original de Filóstrato, y otra lo abreviara. ${ }^{254}$ Ya a finales del siglo XX vio la luz el trabajo de D. K. Raïos, ${ }^{255}$ quien, de forma novedosa, analiza y describe los manuscritos que transmiten las Cartas, enriqueciendo de manera notable el número y estudio de los mismos, ${ }^{256}$ así como las ediciones, traducciones y estudios hasta la fecha realizados; como conclusiones provisionales establece este autor la existencia de un arquetipo común para las dos versiones y supone que las diferencias entre ambas se deben, por una parte, a la acción de un censor bizantino y, por otra, al deterioro normal que una tradición manuscrita efectúa sobre el texto. Recientemente se publicó una edición bilingüe de las Lettere d'amore de Alcifrón, Filóstrato y Aristéneto a cargo de F. Conca \& G. Zanetto, poco novedosa en cuanto a la versión griega, puesto que no realiza nuevas recensiones de los códices, sino que simplemente se sirve de la edición de A. R. Benner \& F. H. Fobes. ${ }^{257}$

$\begin{array}{ll}252 & \text { Vid. supra el capítulo 3: Filóstrato y la retórica. } \\ 253 & \text { Vid. K. Münscher, 1907, pp. } 468 \text { ss. } \\ 254 & \text { Vid. F. Solmsen, 1941, pp. } 124 \text { ss. } \\ 255 & \text { Vid. D. K. Raïos, } 1992 \text { y } 1997 . \\ 256 & \text { Piénsese, por ejemplo, en el hasta ahora no estudiado Ambrosianus gr. B } 4 \text { Sup., del }\end{array}$ siglo $\mathrm{x}$, que contiene una antología de las Cartas de Filóstrato junto a otras colecciones epistolares; vid. D. K. Raïos, 1992, pp. 24 ss., y 1997, pp. 102 ss.

257 Según se indica en la introducción, vid. F. Conca \& G. Zanetto, 2005, p. 55, se sigue la edición de A. R. Benner \& F. H. Fobes salvo en algunos pasajes señalados en los que

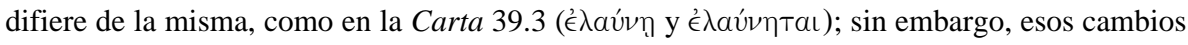

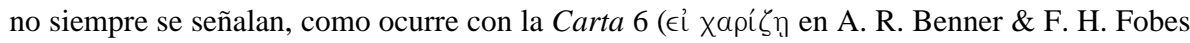

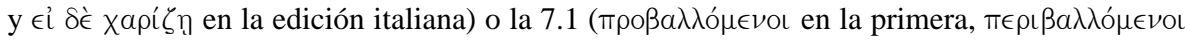
en la segunda). 
Esta traducción sigue principalmente el texto griego editado por A. R. Benner \& F. H. Fobes, 1962 (=1949). ${ }^{258}$ En él se rechaza la desmembración del texto propuesta por C. L. Kayser, aunque se sirve principalmente de sus notas críticas y, en menor medida, de las propias de J. F. Boissonade, ya que no efectúa un nuevo cotejo de los manuscritos, algo que sería deseable en una moderna y precisa edición. ${ }^{259}$ La edición contiene la versión extensa de las Cartas, señalando con medios corchetes la mayor parte de los pasajes que transmite la familia 2 de manuscritos y que C. L. Kayser había eliminado de la versión principal, marca que hemos conservado también en el texto que a continuación presentamos.

La división en distintos parágrafos de las Cartas pertenece a la traductora de las mismas. ${ }^{260}$ Aquellos pasajes en los que hay alguna cita, problema de tipo textual o una lectura distinta a la editada por A. R. Benner \& F. H. Fobes se glosan en unas anotaciones que figuran a continuación del texto y de la traducción de las Cartas, y se señalan en los correspondientes parágrafos con un asterisco (*). A fin de facilitar la comprensión de los distintos comentarios se ha añadido un listado de las ediciones citadas que recoge de forma resumida sus principales características (Tabla IV).

Del desamor como protagonista nos muestra la colección en ocasiones sendas versiones con destinatario masculino y femenino; de algunas de las Cartas su versión destinada al otro sexo carece de expresión de lamento porque la misma temática se desarrolla con resultados distintos. Así la Carta 14 tendría como compañera la 35 ; la 12 , a la 10 ; la 13 , a la 30 ; la 28 , a la 8 ; la 29, a la 56; la 39 , a la 64 ; la 48 , a la 53; la 59, a la 15 . Al final de esta introducción (Tabla I), se ofrece un listado de esas parejas de Cartas que comparten la temática y diferencian entre destinatarios femeninos y masculinos, al que se añaden aquellas que carecen de pareja con expresión

\footnotetext{
258 Vid. pp. 404 ss. acerca de los criterios que rigen esta edición y acerca de los defectos de la de C. L. Kayser.

259 Algo que esta misma edición reclama (p. 405: «[...] In view of these uncertainties the Letters of Philostratus can never be edited properly without a recollation of the MSs. preferably a recollation on the basis of Family 2»). Seguimos a la espera de la anunciada edición en la Collection des Universités de France a cargo de S. Follet y D. K. Raïos (vid. S. Follet, 1997, p. 135, y 2002, p. 249).

260 La edición de A. R. Benner \& F. H. Fobes, 1962, no establece ninguna división entre párrafos, que aquí se ha añadido para facilitar su consulta. Sí incluían cierta parcelación las Cartas más largas en las ediciones de A. Westermann, 1878, y R. Hercher, 1873, pero sobre el texto cercenado de la familia 1 de manuscritos.
} 
de lamento entre paréntesis. La Carta 6, ya se ha comentado, aparentemente es la única de la colección sin su correlato del otro sexo, que asimismo ignoramos debido a la ambigüedad del billetito.

En las ediciones anteriores a la de C. L. Kayser, 1844, aparecían agrupadas estas parejas o conjuntos de cartas con temática similar, ${ }^{261}$ mientras que, al desestimar los manuscritos de la familia $2,{ }^{262}$ C. L. Kayser siguió un orden más acorde con la otra rama, que en las ediciones y traducciones posteriores se ha seguido reproduciendo. ${ }^{263}$ Esa última numeración es la que se ha utilizado a lo largo de este estudio en aras de una mayor comodidad, ${ }^{264}$ pero a la hora de recoger esta selección y su traducción se ha preferido mantener la colocación -manteniendo la numeración de C. L. Kayser- de la familia 2 de manuscritos ${ }^{265}$ porque agrupa temáticamente las Cartas y, además, de forma alternante a destinatarios masculinos y femeninos. De ese modo aparecen en su mayoría seguidas o en el mismo grupo las cartas que se corresponden temáticamente, tanto las parejas que aquí se estudian ( 5 y 47, 7 y 23, 11 y 50, 24 y 25, 57 y 26, 16 y 61) como aquellas cuyo correlato no expresa lamento (12, 13, 28, 29, 59; la 14 y la 39 son las que, con una temática más diferenciada, quedan un poco aisladas), o carecen de pareja (6), ${ }^{266}$ salvo la Carta 48, que no está recogida en esta familia de manuscritos (ni tampoco su correlato 53). Así las cosas, parece aconsejable leer las Cartas en el orden que nos transmiten los manuscritos de esa familia 2 (véase Tabla II), sin olvidar añadir la Carta 48 que no figura en ellos. Y, de esta forma, leeremos también de forma agrupada diferentes cartas sobre un mismo tema, como la pareja 11 y 50 seguidas de la 12 y la

261 Tal y como se recogían en la llamada segunda familia de manuscritos, alternando los destinatarios masculinos y femeninos. Esta elaborada disposición desaparecía en la otra familia de manuscritos, lo que parece apoyar, en opinión de K. Münscher, la antigüedad y originalidad de esa familia 2.

262 Acerca de las distintas ordenaciones en función de la familia de manuscritos que se siga y en función de los criterios observados, vid. A. R. Benner \& F. H. Fobes, 1962, pp. 399 ss.

263 C. L. Kayser, 1944, pp. IV ss. del proemio que precede a las epístolas. Mantienen su numeración A. Westermann, 1878, R. Hercher, 1873, A. R. Benner \& F. H. Fobes, 1962, F. Conca \& G. Zanetto, 2005. Vid. las tablas con las distintas correspondencias que presenta la edición de A. R. Benner \& F. H. Fobes, 1962, pp. 398 ss., especialmente la Tabla II, p. 403.

264 Vid. las razones que argumentan A. R. Benner \& F. H. Fobes, 1962, p. 402, para justificar la elección de la disposición propuesta por C. L. Kayser.

265 Vid. A. R. Benner \& F. H. Fobes, 1962, p. 403.

266 En la familia 2 de manuscritos aparece entre las parejas 5 y 47 y 7 y 23. 
29, o la 13 seguida de la 59. Para facilitar la localización de una carta se ha añadido una tercera tabla (III) que recoge la numeración de C. L. Kayser y la página en la que aquí aparece. 


\section{Correspondencias temáticas}

(Tabla I)

\begin{tabular}{|c|c|}
\hline Meı pakíw & Гиvaıкí \\
\hline Carta 5 & Carta 47 \\
\hline \multicolumn{2}{|c|}{ Carta 6} \\
\hline Carta 7 & Carta 23 \\
\hline Carta 11 & Carta 50 \\
\hline (Carta 10) & Carta 12 \\
\hline Carta 13 & (Carta 30) \\
\hline Carta 14 & (Carta 35) \\
\hline Carta 16 & Carta 61 \\
\hline Carta 24 & Carta 25 \\
\hline Carta 57 & Carta 26 \\
\hline (Carta 8) & Carta 28 \\
\hline (Carta 56) & Carta 29 \\
\hline (Carta 64) & Carta 39 \\
\hline Carta 48 & (Carta 53) \\
\hline (Carta 15) & Carta 59 \\
\hline
\end{tabular}


Orden según los manuscritos de la familia 2

(Tabla II)

\begin{tabular}{|c|c|}
\hline Мєıракі́ $\omega^{267}$ & Гvvaıkí \\
\hline Carta $5(41)^{268}$ & Carta 47 (42) \\
\hline \multicolumn{2}{|c|}{ Carta 6 (43) } \\
\hline \multirow[t]{2}{*}{ Carta 7 (44) } & Carta 23 (45) \\
\hline & Carta 28 (47) \\
\hline \multirow[t]{3}{*}{ Carta 11 (48) } & Carta 50 (49) \\
\hline & Carta 12 (51) \\
\hline & Carta 29 (53) \\
\hline Carta 24 (54) & Carta 25 (55) \\
\hline Carta 57 (56) & Carta 26 (57) \\
\hline \multicolumn{2}{|l|}{ Carta 13 (59) } \\
\hline & Carta 59 (62) \\
\hline Carta 16 (26) & Carta 61 (64) \\
\hline Carta 14 (19) & \\
\hline
\end{tabular}

Carta 39 (70)

267 A estas debe añadirse la Carta 48, que no aparece en la familia 2 de manuscritos, recogida en último lugar en esta selección.

268 Entre paréntesis se recoge la numeración de la edición de G. Olearius, 1709, la misma que siguió J. F. Boissonade, 1842, más próxima a lo transmitido por la familia 2 de manuscritos. 


\section{Índice de esta selección}

(Tabla III)

\begin{tabular}{|c|c|}
\hline Carta $5^{269}$ & p. $\quad 94-95$ \\
\hline Carta 6 & p. $\quad 98-99$ \\
\hline Carta 7 & p. $100-103$ \\
\hline Carta 11 & p. $110-111$ \\
\hline Carta 12 & p. $114-115$ \\
\hline Carta 13 & p. $126-127$ \\
\hline Carta 14 & p. $136-137$ \\
\hline Carta 16 & p. $130-133$ \\
\hline Carta 23 & p. $104-105$ \\
\hline Carta 24 & p. $118-119$ \\
\hline Carta 25 & p. $120-121$ \\
\hline Carta 26 & p. $124-125$ \\
\hline Carta 28 & p. $106-109$ \\
\hline Carta 29 & p. $116-117$ \\
\hline Carta 39 & p. $138-139$ \\
\hline Carta 47 & p. $\quad 96-97$ \\
\hline Carta 48 & p. $140-141$ \\
\hline Carta 50 & p. $112-113$ \\
\hline Carta 57 & p. $122-123$ \\
\hline Carta 59 & p. $128-129$ \\
\hline Carta 61 & p. $134-135$ \\
\hline
\end{tabular}

269 Numeración de C. L. Kayser, 1844, pero respetando el orden los manuscritos de la familia 2.

Monografías de Filología Griega 20. ISSN 1136-0860 


\title{
Resumen de las ediciones empleadas
}

\author{
(Tabla IV)
}

G. OlEARIUS, 1709: primera edición del corpus completo de las Cartas eróticas. Texto griego y traducción latina, con anotaciones de tipo textual y literario.

J. F. Boissonade, 1842: reproduce el proemio de G. Olearius y parte de sus anotaciones en el comentario. Realiza una nueva colación de algunos manuscritos para esta nueva edición del texto griego al que sigue un comentario detallado de carácter textual (señala la procedencia de las distintas lecturas) y literario.

C. L. KAYSER, 1844: aumenta considerablemente el número de manuscritos utilizados para fijar su texto. Concede mayor antigüedad y, por lo tanto, originalidad y corrección, a una de las familias de códices que nos ha legado la tradición. Realiza una nueva disposición en el orden de las epístolas -que las posteriores ediciones mantendrán- de acuerdo con lo transmitido por esa familia 1 o «melior». En un primer pie de página edita los pasajes que él considera añadidos posteriores a esa antigua versión de las Cartas, los textos contenidos en la llamada familia 2. A continuación, un aparato crítico señala la procedencia de las diferentes lecturas. Y recoge al final de la obra unas «Notae in epistolas» que recogen diversas referencias literarias, con las que a menudo justifica sus elecciones.

A. WESTERMANN, 1878 (=1849): reproduce a grandes rasgos el texto y las innovaciones de C. L. Kayser: cercena las Cartas y coloca los fragmentos de la segunda familia a pie de página, con traducción al latín de ambas partes. En el prefacio indica los pocos cambios que modifican su versión modelo.

C. L. KAYSER, 1870-1871: reedición de su trabajo anterior que ubica las anotaciones críticas de forma previa a los textos, que siguen manteniendo los «añadidos» a pie de página. Realiza algún cambio en el texto griego y añade propuestas que en la anterior edición sólo había sugerido en el aparato crítico. Elimina las «Notae» finales de 1844.

R. HERCHER, 1873: muy a su pesar reproduce el texto de C. L. Kayser, sobre el que realiza ligeros cambios recogidos en su «Adnotatio critica». Sólo edita el texto de la familia 1, el que C. L. Kayser consideró más antiguo y próximo al original, al que acompaña una traducción al latín.

A. R. BENnER \& F. H. Fobes, 1962 (=1949): edita de forma unificada ambas versiones de las Cartas, ya que rechaza las teorías de C. L. Kayser, si bien sigue principalmente sus anotaciones críticas ya que no realiza un nuevo cotejo de manuscritos. Sin embargo, suele decantarse, casi de forma sistemática, por las lecturas de la familia 2, las que C. L. Kayser había relegado masivamente a un segundo lugar. Contiene una traducción al inglés, unas anotaciones críticas de los pasajes más problemáticos y otras anotaciones de carácter literario.

F. CONCA \& G. ZANETTO, 2005: su versión griega sigue, salvo contadas excepciones, la de A. R. Benner \& F. H. Fobes, y está acompañada de una traducción al italiano y un cuerpo de notas relativas en su mayoría a las referencias literarias. 

Selección de Cartas

Monografías de Filología Griega 20. ISSN 1136-0860 


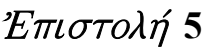

\section{Meıрakí}

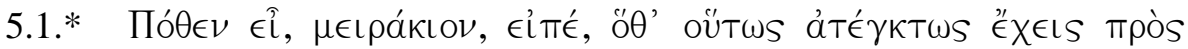

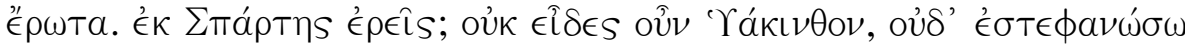

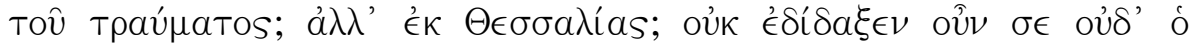

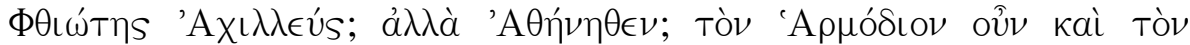

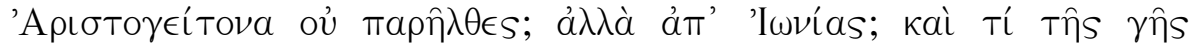

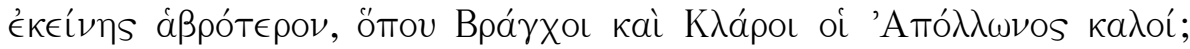

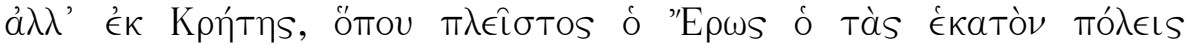
$\pi \in \rho เ \pi \mathrm{L} \hat{\omega} \nu$;

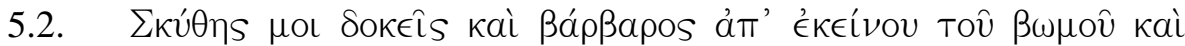

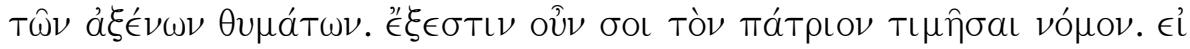

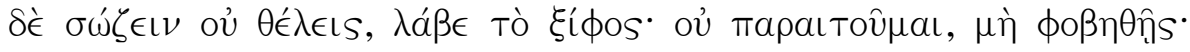

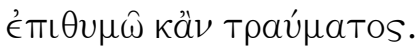




\title{
Carta 5
}

\begin{abstract}
A un muchacho
5.1.* Dime, muchacho, de dónde eres, para permanecer tan impasible ante el amor. ¿De Esparta dirás? ¿No has visto entonces a Jacinto, ni te has hecho una corona de su herida? ¿Acaso de Tesalia? ¿No te enseñó entonces nada Aquiles de Ftía? ¿Acaso ateniense? ¿'No has pasado entonces ante Harmodio y Aristogitón? ¿Quizá de Jonia? ¿Y qué hay más tierno que esa tierra, donde están los Brancos y los Claros, los queridos de Apolo? ¿O de Creta, donde se halla en mayor medida Eros, el que domina las cien ciudades?

5.2. ¡Un escita me pareces a mí, y un bárbaro, a juzgar por ese altar y esas inhóspitas ofrendas! Puedes entonces honrar una costumbre patria y, si no quieres salvarme, coge el puñal. No es una forma de súplica, no temas: incluso que me hieras deseo.
\end{abstract}




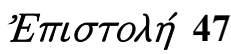

\section{Гvvaıkí}

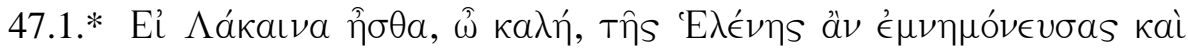

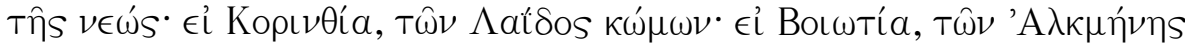

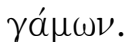

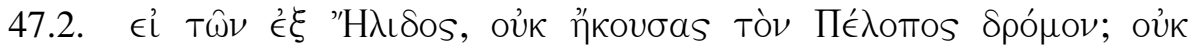

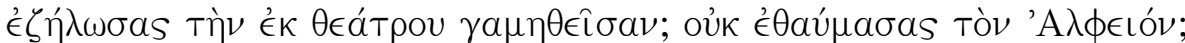

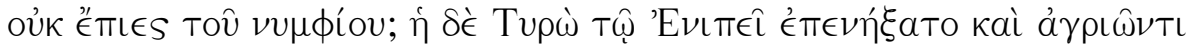

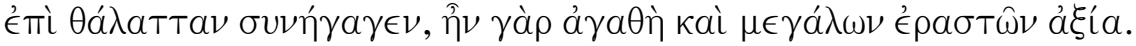

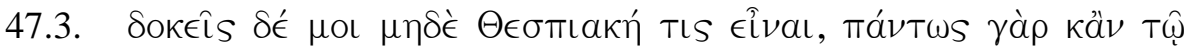

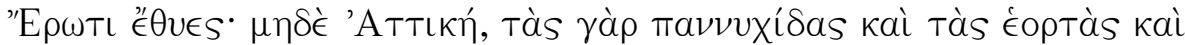

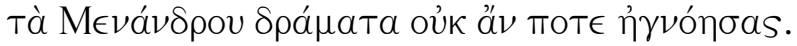

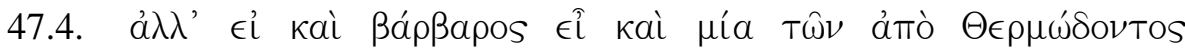

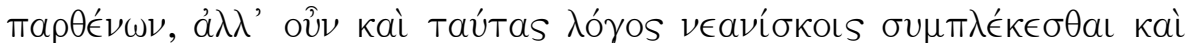

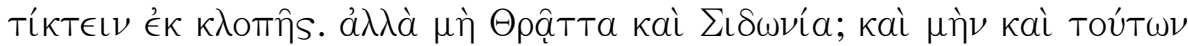

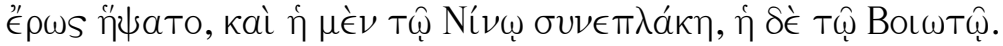

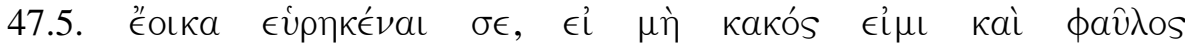

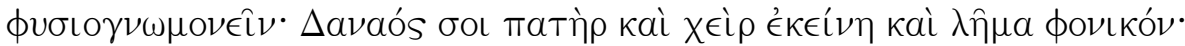

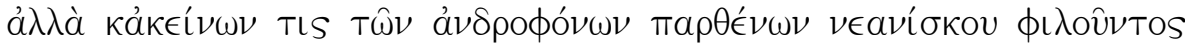

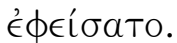

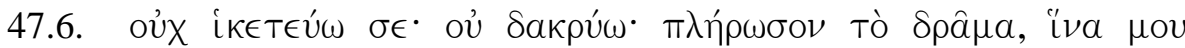

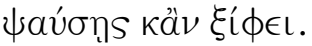




\section{Carta 47}

\section{A una mujer}

47.1. Si laconia fueras, preciosa mía, te acordarías de Helena y de la nave; si fueras corintia, de los cabellos de Lais; si beocia, de las bodas de Alcmena.

47.2. Si de Elis procedes, ¿es que no has oído hablar de la carrera de Pélope? ¿No has envidiado a la que de ese espectáculo pasó a ser desposada? ¿No te maravilla Alfeo? ¿No has bebido los vientos por el novio? Y en cuanto a Tiro, ella nadó en el río Enipeo, con el que se unió en su frenético camino hacia el mar, pues era valerosa y digna de fuertes amantes.

47.3. Ni de Tespias creo que seas, porque en ese caso ofrecerías sin duda sacrificios a Eros; ni tampoco del Ática, ya que entonces no habrías ignorado los festivales nocturnos, ni los días de fiesta, ni los dramas de Menandro.

47.4. Por más que seas bárbara y una de las doncellas de Termodonte, aun así también de ellas se dice que mantenían relaciones con los jóvenes y que de esos encuentros furtivos engendraban hijos. ¿No serás tracia o sidonia? Lo cierto es que también de ellas se adueñó el amor: una mantuvo relaciones con Nino y otra con Beocio.

47.5. Me parece que he dado con tu procedencia, si no soy torpe y mal fisonomista: Dánao es tu padre y tienes esa mano y audacia asesina; pero hasta una de aquellas doncellas homicidas salvó la vida de un joven que la amaba.

47.6. No te suplico; no derramo lágrimas; completa el drama, para que me toques siquiera con un puñal. 


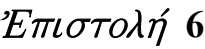

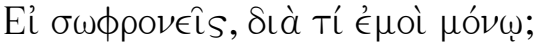

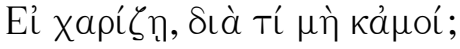




\section{Carta 6}

Si casta te comportas, ¿por qué conmigo sólo?

Si te entregas, ¿por qué no a mí también? 


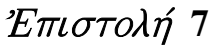

\section{Meıрakí}

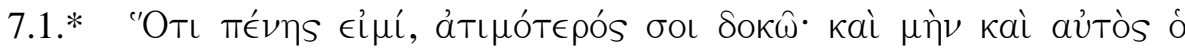

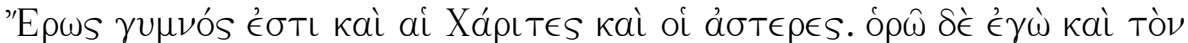

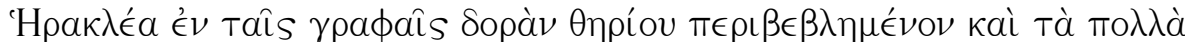

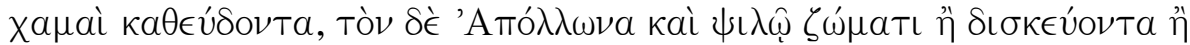

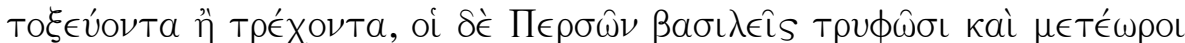

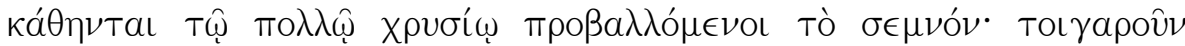

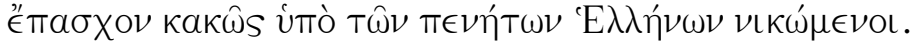

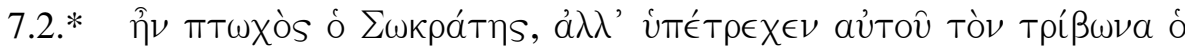

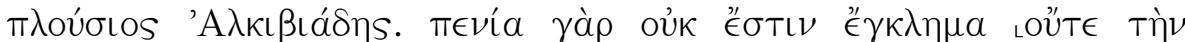

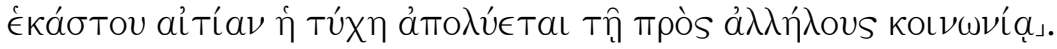

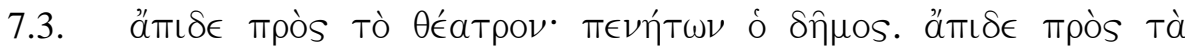

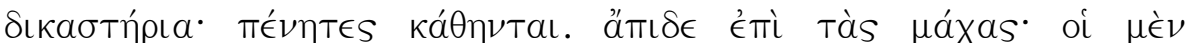

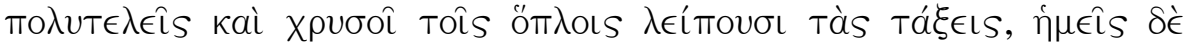

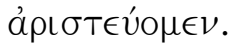

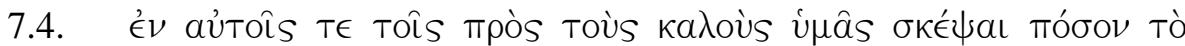

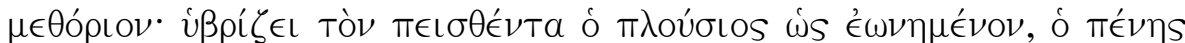

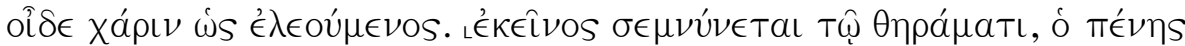

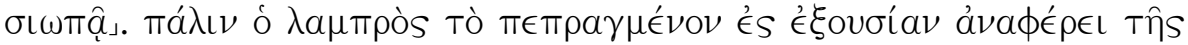

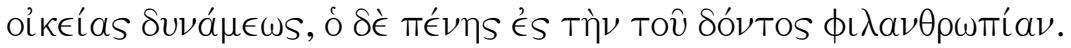

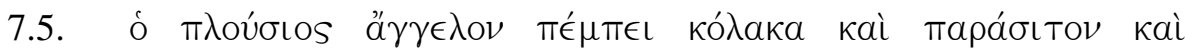

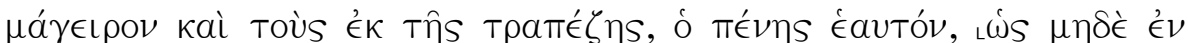

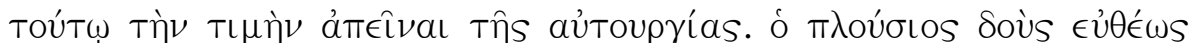

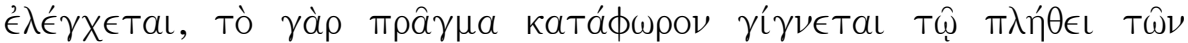

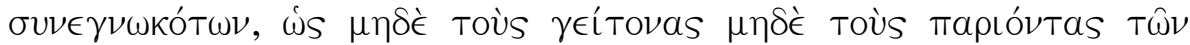

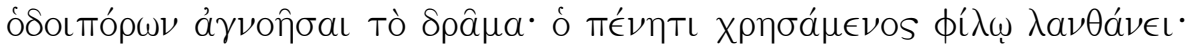

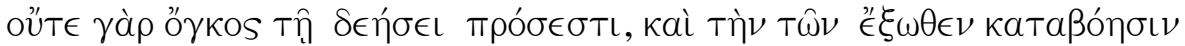




\section{Carta 7}

\section{A un muchacho}

7.1.* Pobre como soy, te crees que valgo menos. Pero lo cierto es que el propio Eros está desnudo, y las Gracias y los astros también. Y en las pinturas veo que Heracles se cubre solo con la piel de una fiera y que suele dormir sobre el suelo; y que Apolo, con su escueto atuendo, lanza el disco, dispara el arco o corre. En cambio, los reyes persas llevan una vida lujosa y se acomodan en las alturas exhibiendo su nobleza con oro en abundancia; por ello sufrieron grandes males derrotados a manos de unos griegos pobres.

7.2.* Humilde era Sócrates, pero detrás de su zamarra iba el rico Alcibíades. Y es que la pobreza no es un baldón, ni la suerte nos libera de responsabilidad en nuestras relaciones personales.

7.3. Fíjate en el teatro: de pobres se compone la población. Fíjate en los tribunales: pobres son los que se sientan. Fíjate en las batallas: los ricos y adinerados abandonan las filas con sus armas, en cambio nosotros destacamos por nuestro valor.

7.4. $\quad$ Y si pasamos a hablar de vosotros, los que sois guapos, mira la diferencia: con aquel que se ha entregado se enfada el rico como si lo hubiera comprado; el pobre está agradecido como si de él se hubieran compadecido. Aquel se vanagloria de su caza; el pobre guarda silencio. De nuevo, ese, que es tan espléndido, atribuye lo conseguido al efecto de su poder personal; mientras, el pobre lo hace a la generosidad del que le obsequia.

7.5. El rico envía como mensajero a un adulador, a un parásito, a un cocinero o a uno de sus sirvientes; el pobre acude en persona, porque hacer esto por sí mismo en nada desmerece al honor. Si el rico se entrega abiertamente, se expone a la crítica, pues el asunto queda al descubierto por el gran número de los que se enteran, de modo que ni los vecinos ni los caminantes que pasan cerca desconocen la trama; el que ama a un pobre 


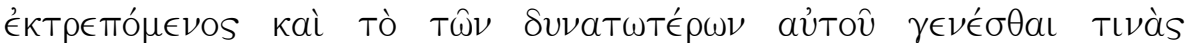

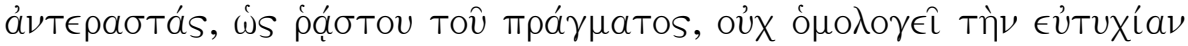

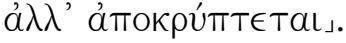

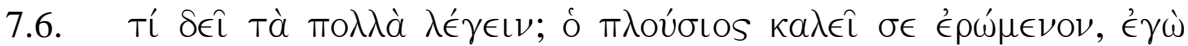

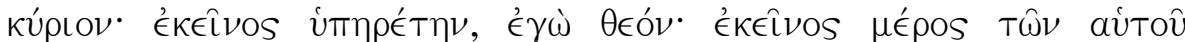

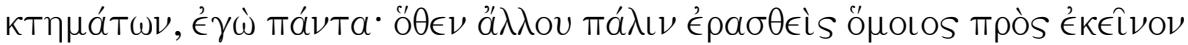

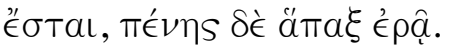

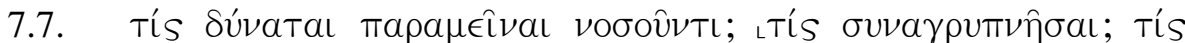

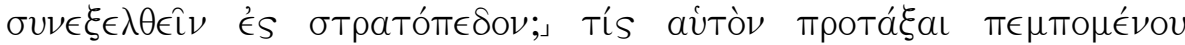

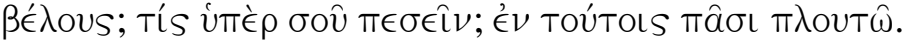


pasa inadvertido. En efecto, la ostentación no es propia del que ha suplicado y, puesto que evita la indiscreción y que le salgan rivales en el amor más poderosos que él, cosa perfectamente factible, no proclama su fortuna, sino que la esconde.

7.6. ¿Qué más se puede decir? El rico te llama «amado», yo «mi señor»; él «sirviente», yo «mi dios»; para él eres "parte de sus posesiones», para mí «lo eres todo»: por ello si el rico se vuelve a enamorar, se comportará igual con el nuevo; en cambio, el pobre sólo una vez ama.

7.7. ¿Quién puede permanecer fiel junto a un enfermo? ¿Quién compartir la vigilia? ¿Quién acompañar al campo de batalla? ¿Quién interponerse ante una flecha disparada? ¿Quién caer por ti? En todas estas cosas yo soy rico. 


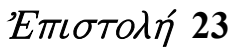

\section{Гvvaıkí}

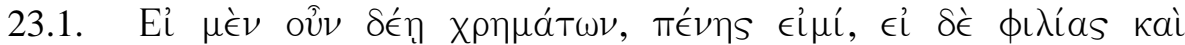

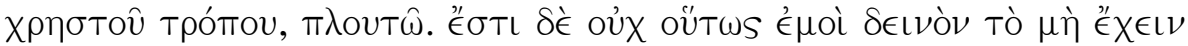

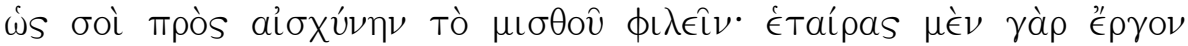

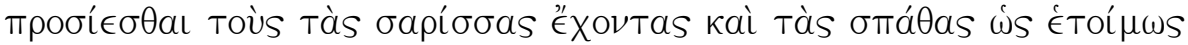

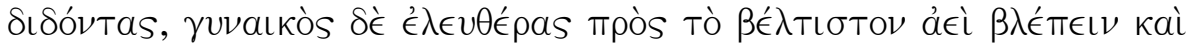

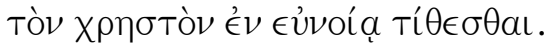

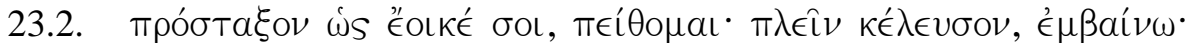

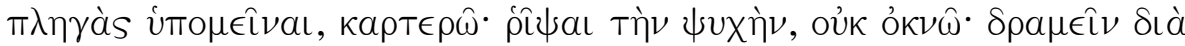

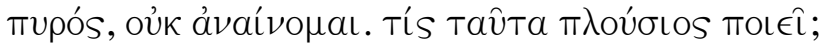




\title{
Carta 23
}

\begin{abstract}
A una mujer
23.1. Si dinero es lo que pides, pobre soy; si es amistad y un amable trato, en esto soy rico. No es tan terrible para mí el no tener como para ti es una vergüenza amar por dinero: así es, el trabajo de una hetera consiste en acercarse a los que llevan las picas y las espadas, porque están dispuestos a gastar; pero una mujer libre siempre busca lo mejor y ofrece su afecto al que es bueno.

23.2. Ordéname lo que te parezca, que yo obedezco: mándame a navegar, que yo me embarco; a recibir golpes, que yo los soporto; a arrancarme el alma, que no vacilo; a caminar sobre el fuego, que no me niego. ¿Qué rico hace estas cosas?
\end{abstract}




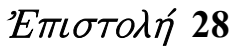

\section{Гvvaıkí}

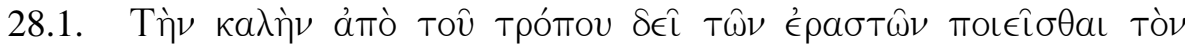

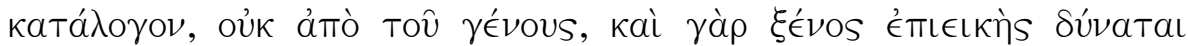

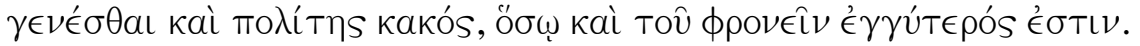

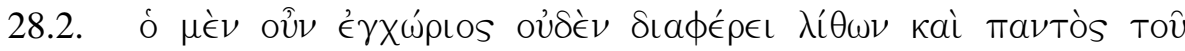

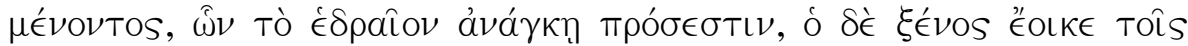

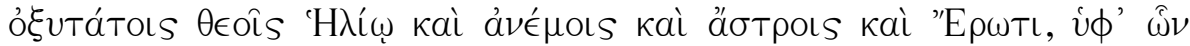

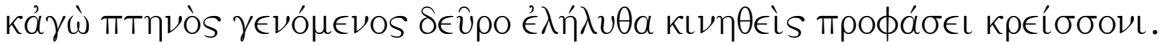

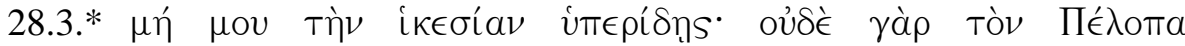

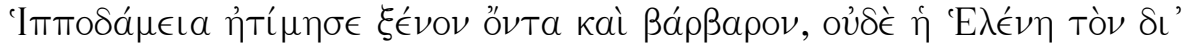

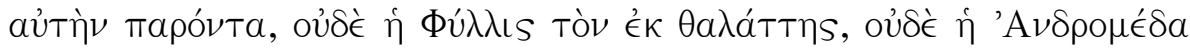

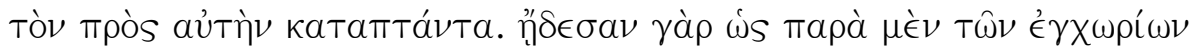

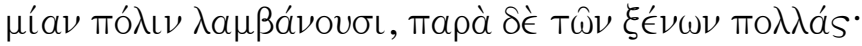

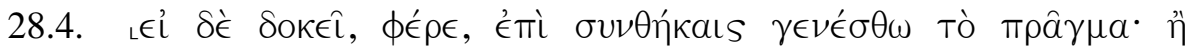

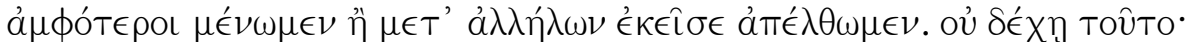

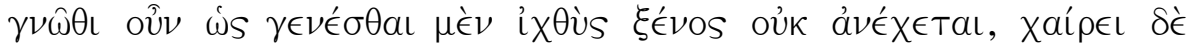

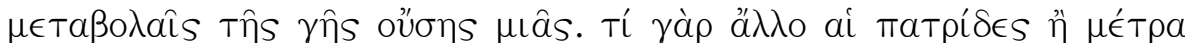

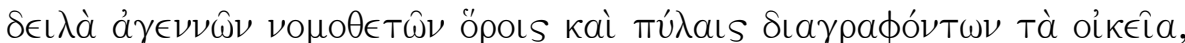

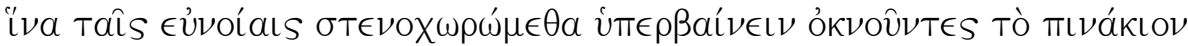

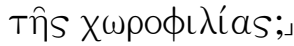

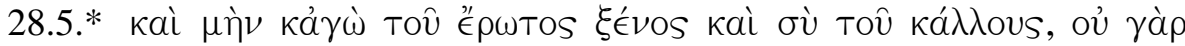

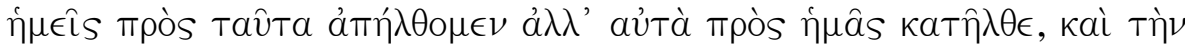

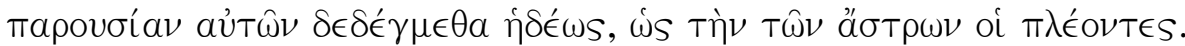

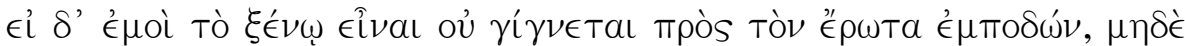

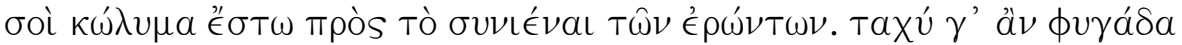




\title{
Carta 28
}

\begin{abstract}
A una mujer
28.1. Es preciso que la mujer hermosa reúna su colección de amantes a partir del carácter y no del linaje, pues, en efecto, es posible que un extranjero resulte conveniente y un ciudadano malo, dependiendo de la medida de su prudencia.
\end{abstract}

28.2. El lugareño, por su parte, en nada se diferencia de las piedras y de todo lo inmóvil, en cuya naturaleza reside la pasividad; sin embargo, el extranjero se parece a las divinidades más veloces, a Helios y a los vientos y a los astros y a Eros: gracias a ellos también yo, con estas alas que me han dado, he llegado hasta aquí impelido por una fuerza muy poderosa.

28.3.* ¡No desprecies mi súplica! Ni siquiera a Pélope desdeñó Hipodamía por ser extranjero y bárbaro; ni Helena al que había ido a buscarla, ni Filis al que llegó del mar, ni Andrómeda al que bajó volando hacia ella. Sabían, en efecto, que de los lugareños ganaban una única ciudad, pero muchas de los extranjeros.

28.4. ¡Vamos, si te parece, tomemos una decisión! O nos quedamos aquí ambos o nos marchamos juntos. No estás de acuerdo: entonces date cuenta de que un extranjero no puede soportar vivir como un pez, sino que disfruta de los cambios de tierra, que es una sola. ¿Qué otra cosa son las patrias sino extensiones miserables en las que viles legisladores han señalado las propiedades mediante mojones y puertas para angustiarnos en la ternura de nuestros sentimientos y para que vacilemos a la hora de sobrepasar la marca que han puesto al afecto por un lugar?

28.5.* Lo cierto es que yo soy anfitrión del amor y tú de la belleza, cosas estas que no hemos perseguido nosotros, sino que son ellas las que nos siguen y hemos recibido gratamente su presencia, como los navegantes la de 


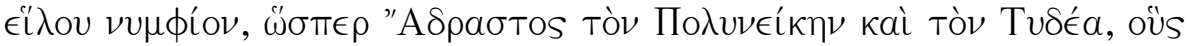

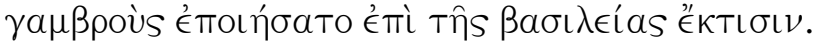

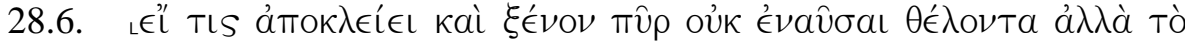

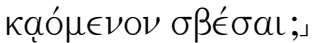

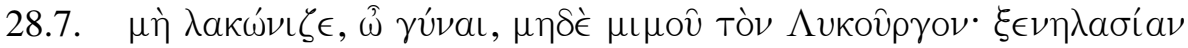

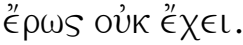


los astros. Y si a mí el hecho de proceder del extranjero no me supone un obstáculo para el amor, que no te resulte a ti un impedimento para comprender a los que aman. Sin duda podrías haber elegido para novio a un exiliado, como Adrasto a Polinices y a Tideo, a quienes convirtió en sus yernos con la intención de recuperar el reino.

28.6. ¿Quién puede rechazar a alguien, aun extranjero, que no desea prender ningún fuego sino apagar un incendio?

28. 7. No te comportes como un laconio, mujer, ni imites a Licurgo: el amor no admite expulsiones de extranjeros. 


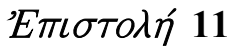

\section{Meıрakí}

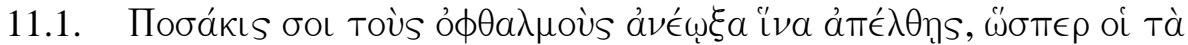

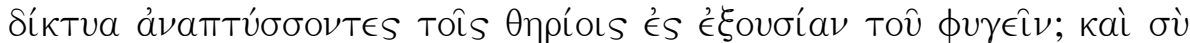

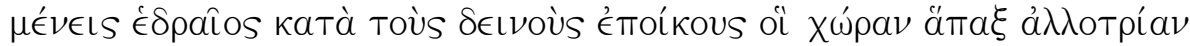

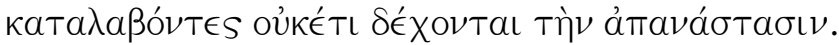

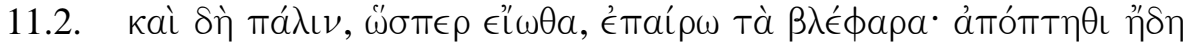

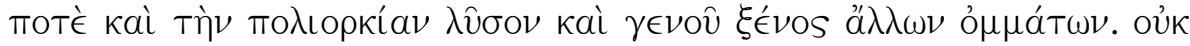

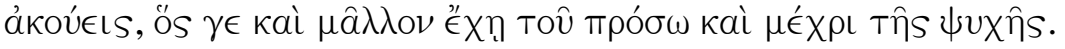

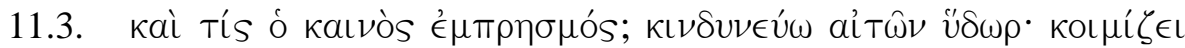

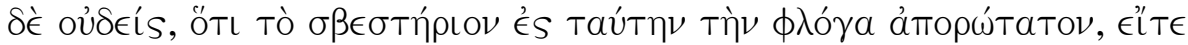

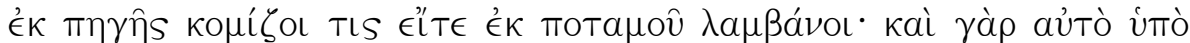
Ép 


\section{Carta 11}

\section{A un muchacho}

11.1. ¿Cuántas veces te abrí mis ojos para que te fueras del mismo modo que se despliegan las redes dando a las fieras la posibilidad de huir? Pero tú permaneces sentado como esos malditos colonos que, una vez que han tomado un territorio ajeno, ya no consienten en levantar el sitio.

11.2. Y así, de nuevo, como de costumbre, alzo mis párpados: sal, vuela ya de una vez, libera el asedio y sé huésped de otros ojos. ¡No me escuchas, sino que aún llegas más lejos, a lo más profundo de mi alma!

11.3. ¿ ¿Y qué es este nuevo fuego? ¡Estoy en peligro, agua pido! Pero nadie me calma, porque nada hay más inalcanzable que apagar esta llama, ni agua de manantial, ni tampoco de río: pues incluso la propia agua arde con mi amor. 


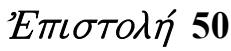

\section{Гvvaıkí}

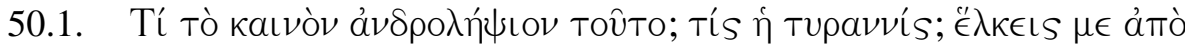

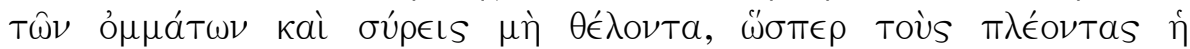

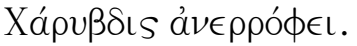

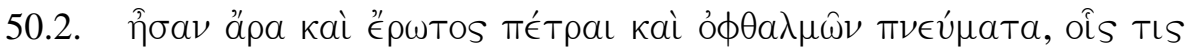

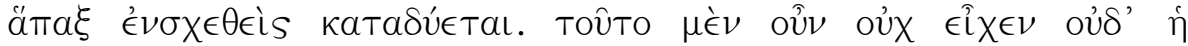

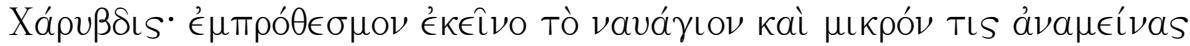

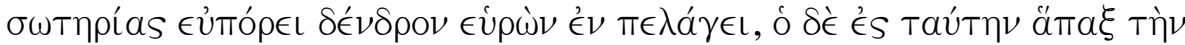

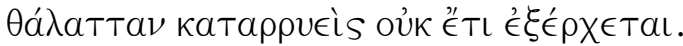




\section{Carta 50}

\section{A una mujer}

50.1. ¿¿Qué es este nuevo secuestro? ¿Qué esta tiranía? Me atraes con tus ojos y, aunque no quiera, me arrastras de la misma forma que Caribdis absorbía a los navegantes.

50.2. Existen, desde luego, escollos de pasión y torbellinos de miradas que, una vez te han atrapado, te hunden. Ahora bien, hay algo que no hacía ni siquiera Caribdis: provocaba un naufragio cada cierto tiempo y, esperando un poco, podías alcanzar la salvación si encontrabas un tronco en el piélago. Sin embargo, quien se ha sumergido por una vez en este tu mar, no sabe ya huir. 


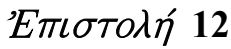

\section{Гvvaıkí}

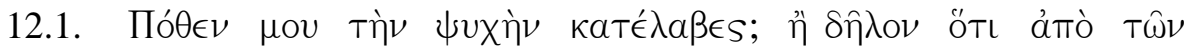

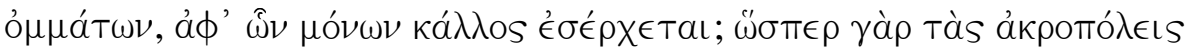

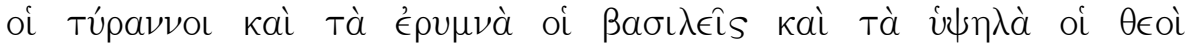

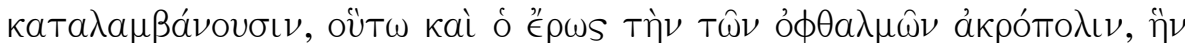

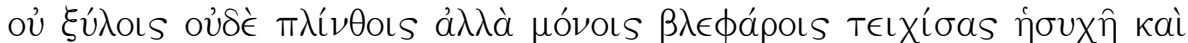

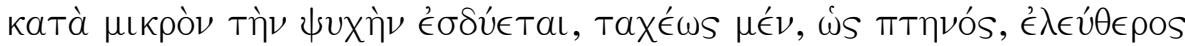

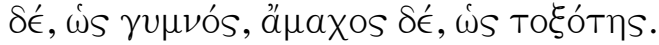

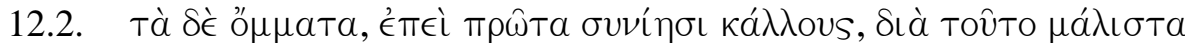

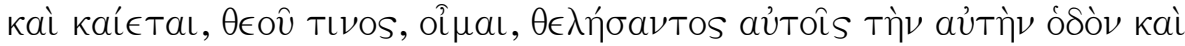

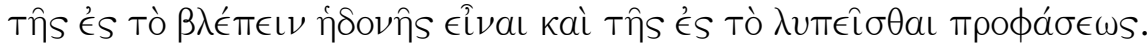

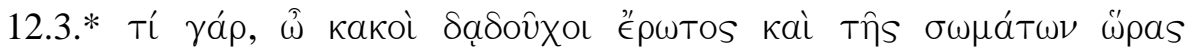

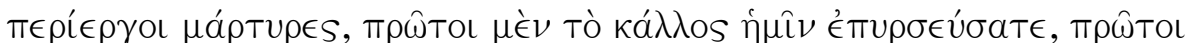

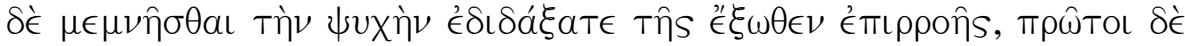

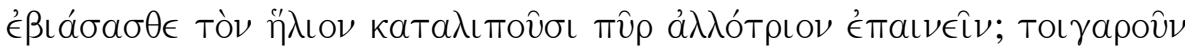

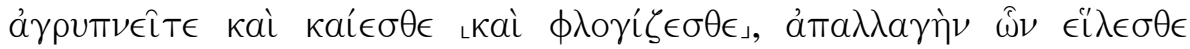

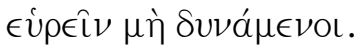

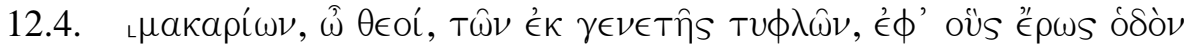
oủk ËX $\mathrm{l}$.. 


\title{
Carta 12
}

\begin{abstract}
A una mujer
12.1. ¿ ¿Por dónde te has apoderado de mi alma? ¿Acaso no está claro que a través de la mirada, la única puerta desde la que puede entrar la belleza? Como los tiranos de las acrópolis, los reyes de las fortalezas y los dioses de las alturas, así también el amor se ha apoderado de la acrópolis de mis ojos, la ha amurallado sin maderos ni ladrillos, sólo con los párpados, y calladamente ha invadido mi alma poco a poco; con ligereza, cual alado; libre, cual desnudo; e invencible, cual arquero.
\end{abstract}

12.2. Los ojos, en cuanto advierten una belleza, por ella se enardecen: alguna divinidad, me parece, les ha deseado que recorra el mismo camino tanto el placer de ver como el motivo del sufrimiento.

12.3.* ¿Por qué, pues, malvados portadores de las antorchas del amor, testigos curiosos de la juventud de los cuerpos, fuisteis los primeros en deslumbrarme con la belleza, pero también los primeros en enseñarle a mi alma a recordar el torbellino del exterior, y los primeros que me forzaron a abandonar al sol para ensalzar un fuego ajeno? Pasad, por lo tanto, las noches en vela, arded y en llamas consumíos, incapaces de encontrar una liberación de aquello que elegisteis.

12.4. ¡Dichosos, oh dioses, los ciegos de nacimiento, para quienes el amor no halla camino alguno! 


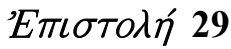

\section{Гvvaıkí}

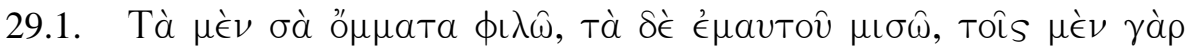

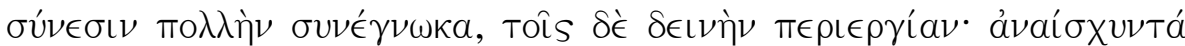

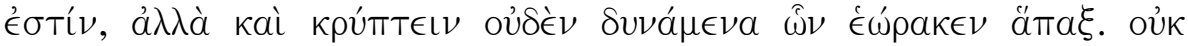

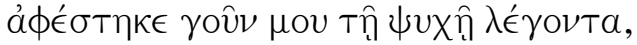

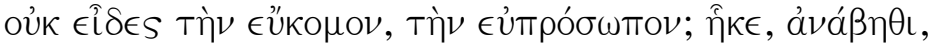

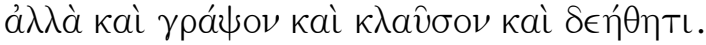

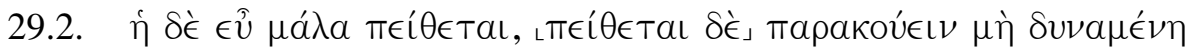

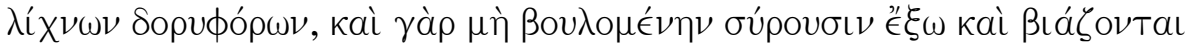

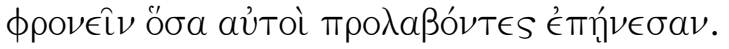

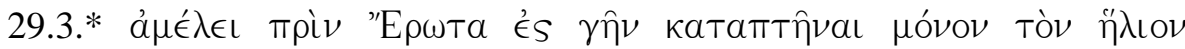

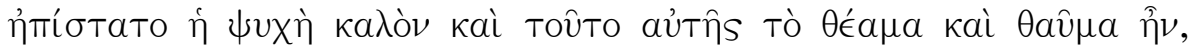

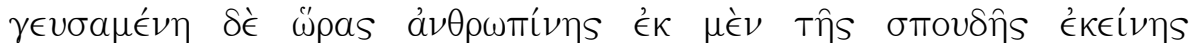

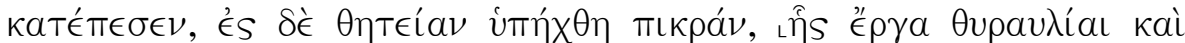

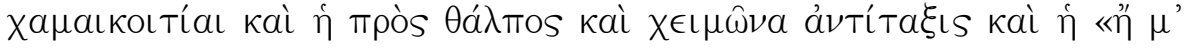

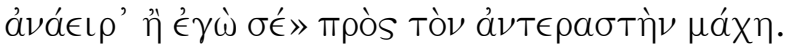

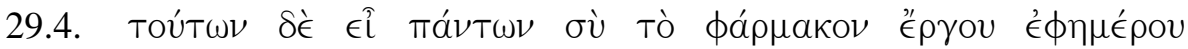

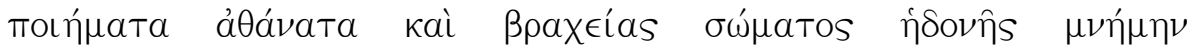

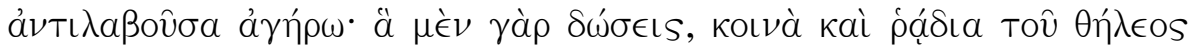

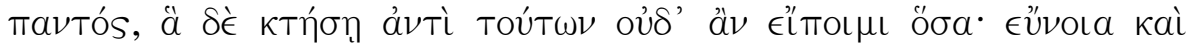

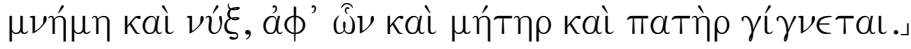




\title{
Carta 29
}

\begin{abstract}
A una mujer
29.1. Tus ojos amo, mas los míos odio, pues en los tuyos reconozco una gran sensatez, pero en los míos una terrible indiscreción. Son unos desvergonzados y nada en absoluto pueden ignorar una vez lo han visto. No paran por ello de decirle a mi alma:
\end{abstract}

¿No has visto a la del hermoso cabello, a la del bello rostro?

Ve, levántate, y escribe, llora, ruégale.

29.2. Y ella, mi alma, seguro que cede. Y cede incapaz de desatender a estos mis curiosos satélites: la arrastran fuera aunque no quiera, y la fuerzan a aceptar cuanto se adelanten ellos a ensalzar.

29.3.* Sin duda, antes de que Eros descendiera volando a la tierra, el alma solo una belleza conocía, el sol, que era su admiración y maravilla. Pero una vez que saboreó el esplendor humano, de aquella voluntad desistió y fue reducida a una amarga servidumbre, cuyas obligaciones son esperar a las puertas y dormir sobre el suelo, la resistencia bajo el calor ardiente y el invierno, la lucha contra el rival en amores:

O me levantas tú a mí o yo a ti.

29.4. De todas estas cosas tú eres el remedio, si aceptas obras inmortales a cambio de un servicio efímero, y el recuerdo eterno a cambio de un breve placer del cuerpo. Pues las prendas que vas a entregar son comunes y fáciles para toda mujer; en cambio, tantas recibirías en su lugar que no podría ni enumerarlas: cariño, recuerdo y noche, de lo que una madre y un padre proceden. 


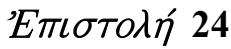

\section{Meıракí}

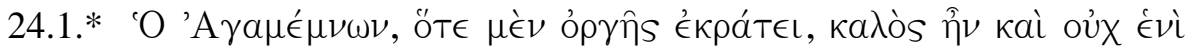

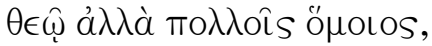

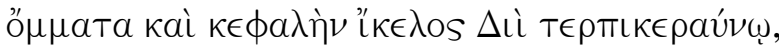

"А $\rho \in \ddot{i} \delta \dot{~ \zeta \omega ́ v \eta \nu, ~ \sigma T \epsilon ́ \rho \nu o \nu ~ \delta e ́ ~ П o \sigma \in ı \delta a ́ \omega \nu l, ~}$

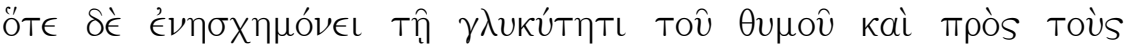

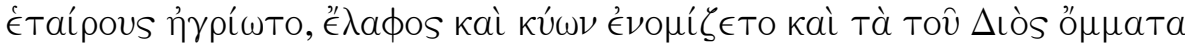

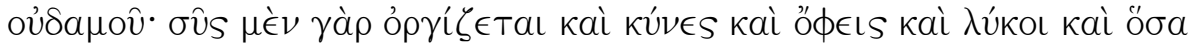

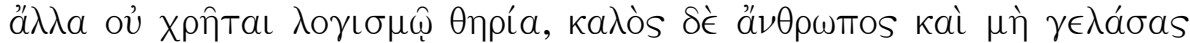

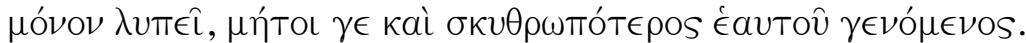

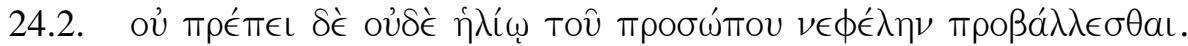

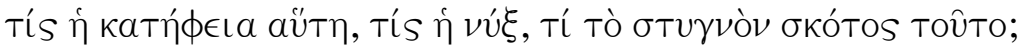

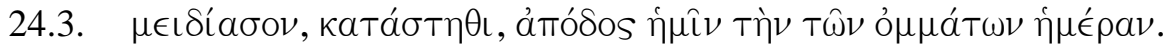




\section{Carta 24}

\section{A un muchacho}

24.1.* Agamenón cuando contenía su furia, resultaba atractivo y no se asemejaba a un solo dios sino a muchos:

En los ojos y en la cabeza parecido a Zeus que disfruta con el rayo, a Ares en su cintura y en el pecho a Posidón.

Pero cuando con esa delicia de temperamento se comportaba indecorosa y fieramente con sus compañeros, un venado o un perro parecía y ya no se veían por ninguna parte los ojos de Zeus: pues el jabalí se enfurece y los perros y las serpientes y los lobos y todas las demás bestias irracionales, mas si la persona hermosa hace daño con solo dejar de sonreír, imagínate cuando está más arisco de lo normal.

24.2. No está nada bien que una nube cubra el rostro del sol. ¿Qué es este abatimiento, qué esta noche, qué esta horrible oscuridad?

24.3. Sonríe, cálmate, devuélvenos la luz de tus ojos. 


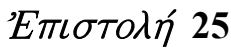

\section{Гvvaıkí}

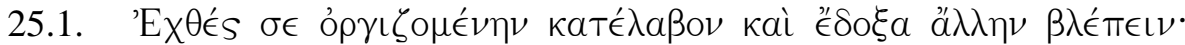

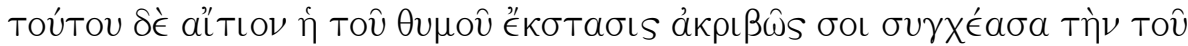

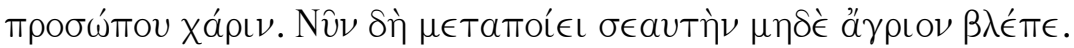

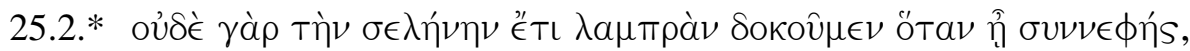

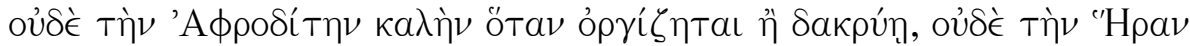

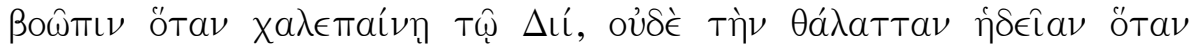

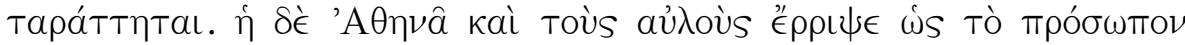

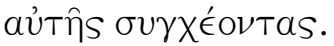

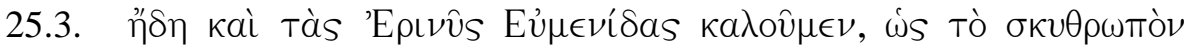

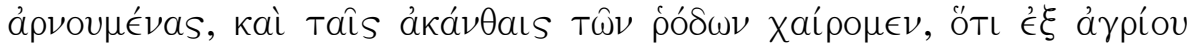

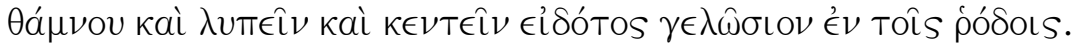

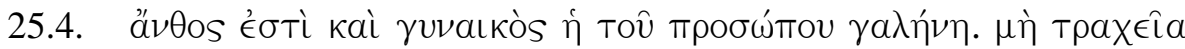

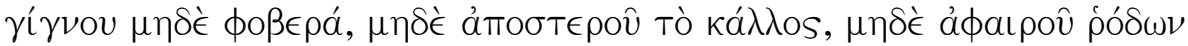

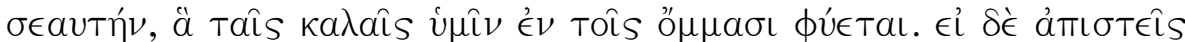

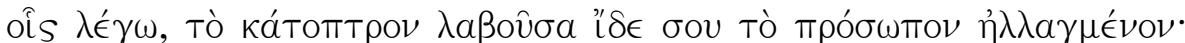

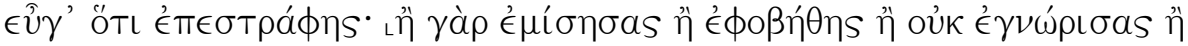
$\mu \in T \in \nu o ́ \eta \sigma a s$. 


\title{
Carta 25
}

\begin{abstract}
A una mujer
25.1. Ayer te encontré enfurecida y pensé que veía a otra; y la culpa la tienen exactamente los arrebatos de tu temperamento que deforman la gracia de tu rostro. Compórtate ahora de otro modo y no te muestres fiera.

25.2.* Pues tampoco nos parece ya brillante la luna cuando hay nubes; ni hermosa Afrodita cuando está furiosa o llora; ni grandes los ojos de Hera cuando está enojada con Zeus; ni agradable la mar cuando está revuelta. Y Atenea hasta de la flauta se deshizo porque deformaba su rostro.

25.3. Incluso a las Erinias las llamamos ya Euménides, porque rechazan su sombrío aspecto; y nos deleitamos con las espinas del rosal porque, a pesar de saber que al proceder de una mata salvaje hacen daño y pinchan, resplandecen entre las rosas.

25.4. Una flor es también la serenidad en el rostro de una mujer. No seas cruel ni me intimides, no te despojes de tu hermosura ni cortes tus propias rosas, las que a vosotras las hermosas os brotan en los ojos. Y si desconfías de lo que te digo, coge el espejo y mira cómo ha cambiado tu rostro. ¡Desde luego que te has transformado! Sin duda te has aborrecido o te has horrorizado o no te has reconocido o has cambiado de idea.
\end{abstract}




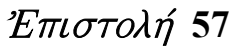

\section{Meıрakí}

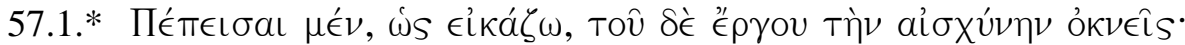

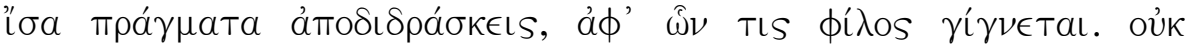

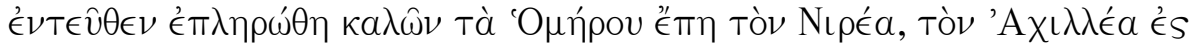

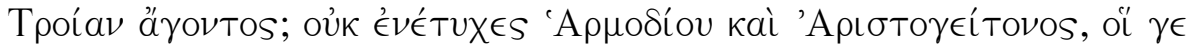

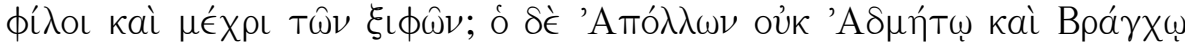

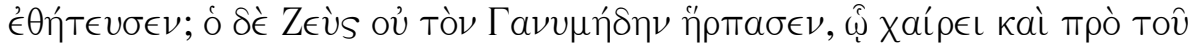

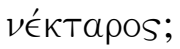

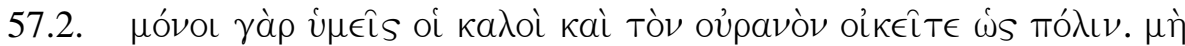

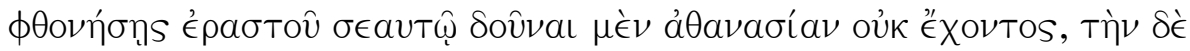

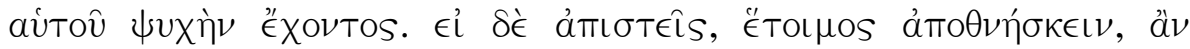

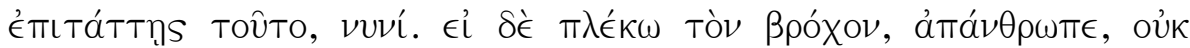

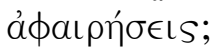




\section{Carta 57}

\section{A un muchacho}

57.1.* Estás convencido, según me parece, pero vacilas por vergüenza a hacerlo: estás evitando las mismas cosas por las que se consigue un amigo. ¿No es por eso que están llenos de guapos muchachos los versos de Homero, que conduce a Nireo, a Aquiles hasta Troya? ¿No has hallado en tu camino a Harmodio y Aristogitón, tan amigos como para dejarse herir por las espadas? ¿Y Apolo no fue sirviente de Admeto y Branco? ¿Y no raptó Zeus a Ganimedes, con quien disfruta incluso más que con el néctar?

57.2. En verdad solo vosotros los guapos podéis habitar lo mismo en el cielo que en una ciudad. No rechaces a un amante que no puede darte la inmortalidad pero sí su propia alma. Y si desconfías, estoy listo para morir, si así lo ordenas, ahora mismo.

¿Si anudo el lazo, tú, desalmado, no lo soltarías? 


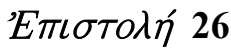

\section{Гvvaıkí}

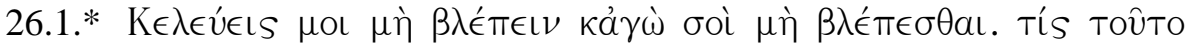

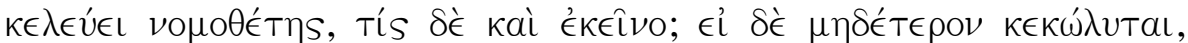

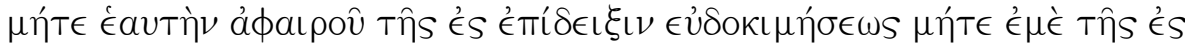

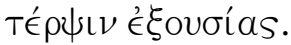

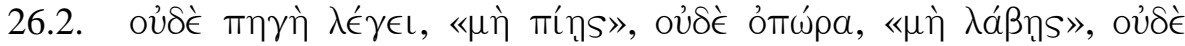

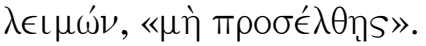

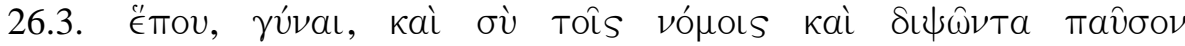

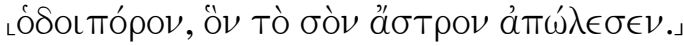




\title{
Carta 26
}

\begin{abstract}
A una mujer
26.1.* Me pides que no te mire, y yo a ti que no te dejes ver. ¿Quién es el legislador que ordena lo uno y lo otro? Si ninguna de las dos cosas está prohibida, ni te prives a ti de la ocasión de presumir, ni a mí de la posibilidad de disfrutar.

26.2. Ninguna fuente dice: «no me bebas», ninguna fruta: «no me cojas», ninguna pradera: «no me pises».

26.3. Acata las leyes también tú, mujer, y calma la sed del viajero sediento al que tu estrella ha perdido.
\end{abstract}




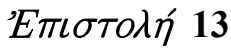

\section{Meıрakí}

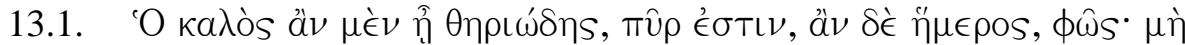

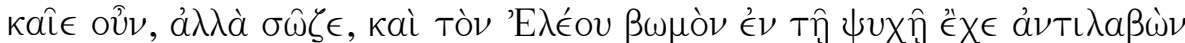

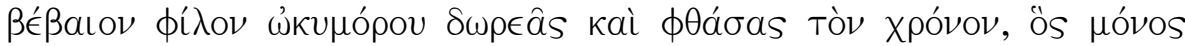

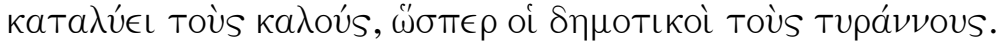

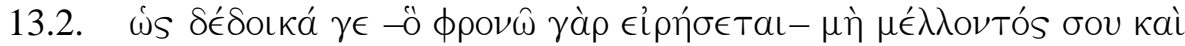

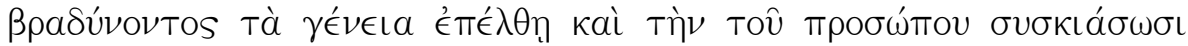

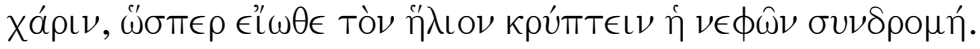

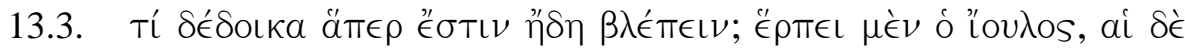

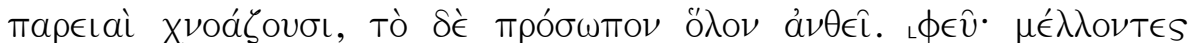

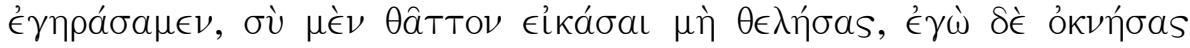
$\delta \in \eta \theta \hat{\eta} v a L$.

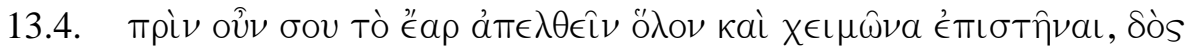

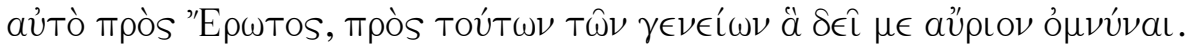




\section{Carta 13}

\section{A un muchacho}

13.1. El guapo, si se comporta como una fiera, es como el fuego; pero, si es afable, resplandece: no me quemes entonces, sálvame, y erige en tu alma el altar de la Piedad, acoge a un amigo fiel a cambio de un presente efímero y anticípate al tiempo, que solo a los chicos guapos destruye, como el pueblo a los tiranos.

13.2. ¡Cuánto temo - sí, diré lo que pienso- que por dudar y demorarte te salga la barba y ensombrezca completamente la gracia de tu rostro, como acostumbra la maraña de nubes a esconder el sol!

13.3. ¡Cómo temo lo que ya se deja ver! Asoma una pelusa y las mejillas se cubren de vello, todo el rostro se está poblando. ¡Ay de nosotros! Por dudar hemos envejecido: tú porque no quisiste aceptarme más rápido, y yo por detenerme a suplicarte.

13.4. Por ello, antes de que se instale el invierno y te abandone del todo tu primavera, ofrécemela, en nombre de Eros y en el de esta barba por la que el día de mañana he de jurar. 


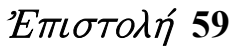

\section{Гvvaıkí}

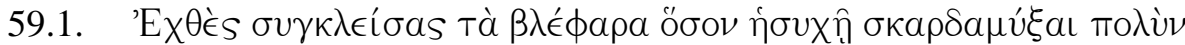

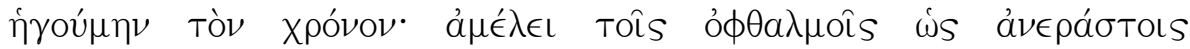
Év

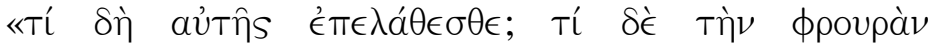

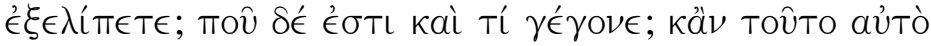
$\mu \eta \nu \dot{\sigma \alpha T \epsilon » .}$

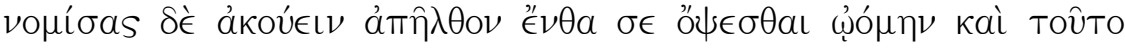

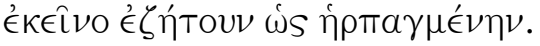

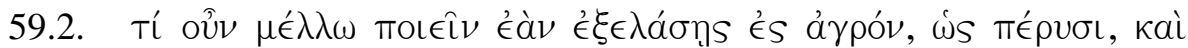

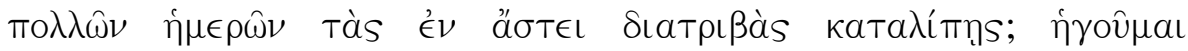

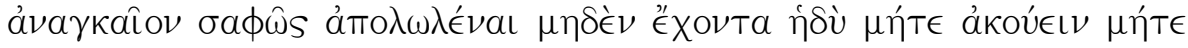
ópâv.

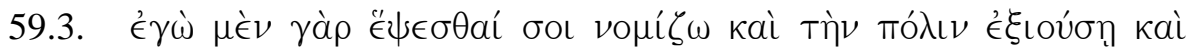

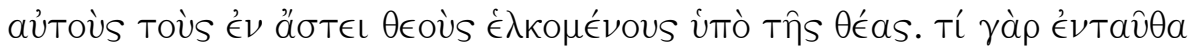

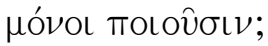

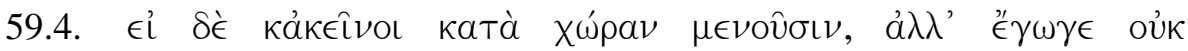

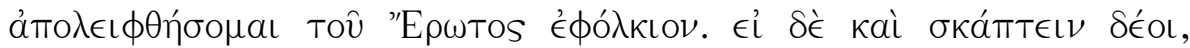

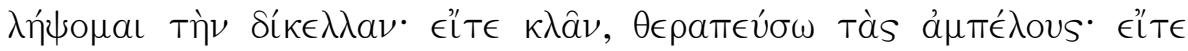

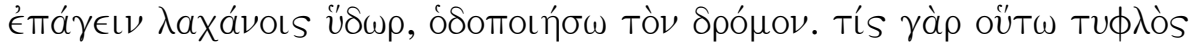

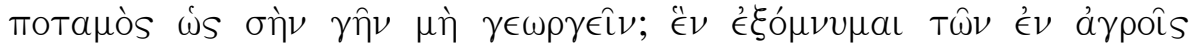

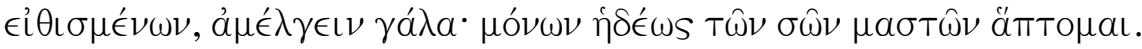




\title{
Carta 59
}

\begin{abstract}
A una mujer
59.1. Cerraba ayer mis párpados, lo justo para pestañear cómodamente y me parecía mucho tiempo; sin reparo reprochaba a mis ojos su incapacidad para el amor:

¿Cómo es que la olvidasteis? ¿Cómo es que descuidasteis vuestra vigilancia? ¿Dónde está y qué ha ocurrido? Esto al menos contádmelo.

Y creí oírlo, fui adonde me parecía que podría verte y trataba de encontrarte como si hubieras sido raptada.

59.2. ¿Qué voy a hacer ahora, si es que te has marchado al campo, como el año pasado, y has abandonado por muchos días tus asuntos en la ciudad? Me parece que por fuerza estoy completamente perdido, sin nada agradable que oír ni ver.

59.3. En mi opinión te seguirán, a ti que te has ido, la ciudad e incluso sus propios dioses arrastrados por tu imagen. ¿Qué van a hacer solos aquí?

59.4. Pero aunque ellos se queden en su sitio, yo, sin embargo, no voy a quedarme atrás, a la zaga del amor: y si fuera preciso cavar, tomaría el azadón; si podar, atendería las vides; si llevar agua a las verduras, abriría la acequia. ¿Pues qué río sería tan ciego como para no fertilizar tu tierra? A una única cosa de las habituales en los campos juro que me niego: a ordeñar leche. Solo tus pechos quiero tocar dulcemente.
\end{abstract}




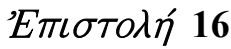

\section{Meıракí}

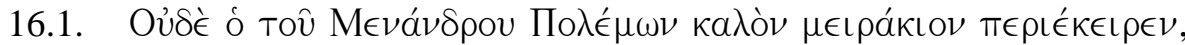

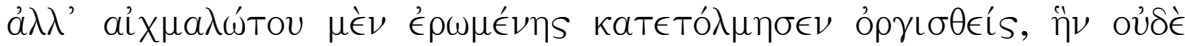

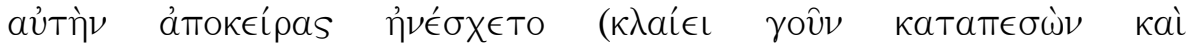

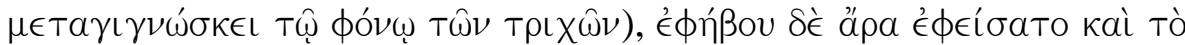

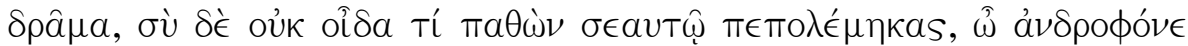

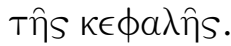

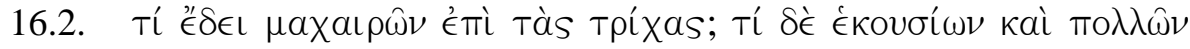

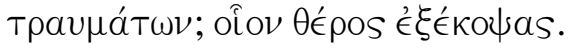

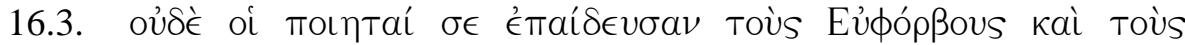

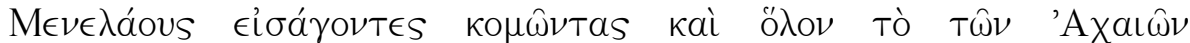

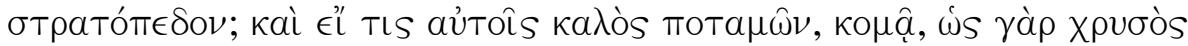

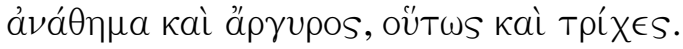

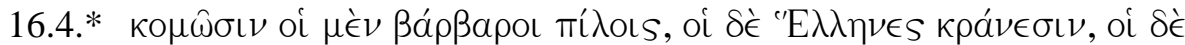

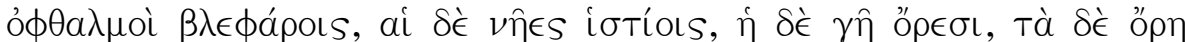

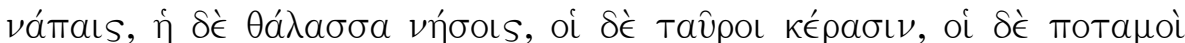

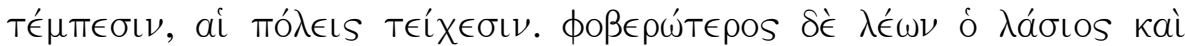

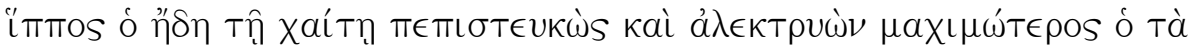

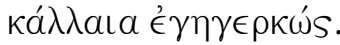

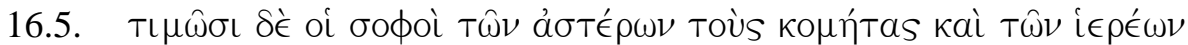

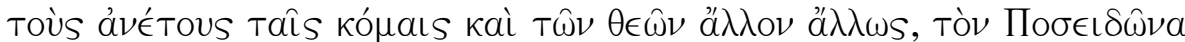

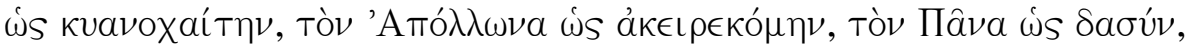

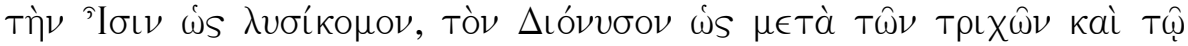

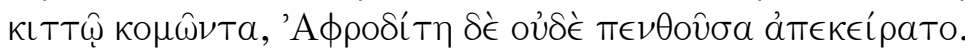

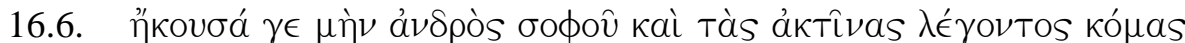

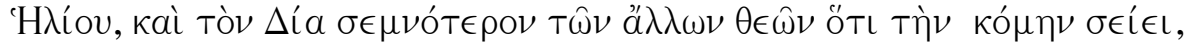




\section{Carta 16}

\section{A un muchacho}

16.1. Polemón en la obra de Menandro no rapó a un hermoso muchacho; sin embargo, contra una cautiva a la que amaba, se envalentonó en un ataque de ira, si bien después no soportó haberla rasurado (y, de hecho, llora cayendo al suelo y se arrepiente del asesinato de sus cabellos); de este modo hasta en el drama se trató con consideración a un joven; en cambio a ti no sé qué te ha ocurrido para luchar contra ti mismo, homicida de tu cabeza.

16.2. ¿Qué necesidad había de cortes sobre tus cabellos? ¿Y de las muchas y voluntarias heridas? ¡Qué cosecha has arrasado!

16.3. ¿ ¿Ni siquiera los poetas te instruyeron, ellos que hacían actuar a los Euforbos y a los Menelaos con sus largas melenas y a todo el ejército de los aqueos? Y si para ellos un río es hermoso, es por su melena; y así como el oro y la plata son ofrendas, así también lo son los cabellos.

16.4.* Largas melenas tienen los bárbaros con sus gorros de piel, los griegos con sus yelmos, las miradas en sus párpados, las naves en sus velas, la tierra con sus montañas, estas en sus cañadas, la mar en sus islas, los toros con sus pitones, los ríos en sus sotos, las ciudades con sus murallas. Más temible es el león melenudo y también el caballo seguro de su crin, y más peleón el gallo cuando alza su cresta.

16.5. Y los sabios honran entre los astros a los cometas, y entre los sacerdotes a los de cabellos libres, y entre los dioses, a cada uno de forma diferente: a Poseidón por su oscura melena, a Apolo por su cabellera sin cortar, a Pan por su abundancia de pelo, a Isis por sus cabellos sueltos, a Dioniso por adornar sus melenas con hiedra; y Afrodita ni siquiera por el luto se rasuró.

16.6. Es más, he oído a un hombre sabio decir que los rayos son cabellos de Helios y que Zeus es el más venerado entre los dioses porque agita su 


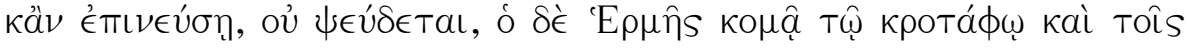
бфupoîs.

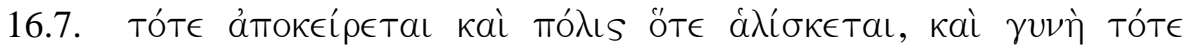

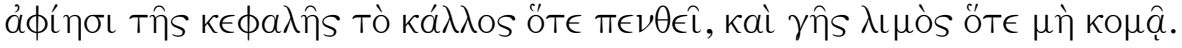

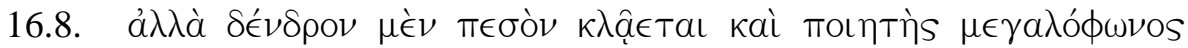

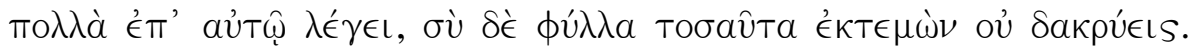

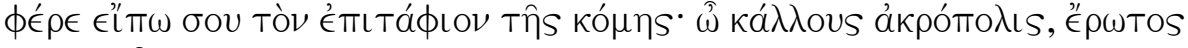

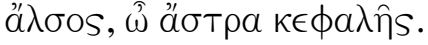


cabellera y, cuando asiente, no miente; además, Hermes tiene pobladas sus sienes y sus tobillos.

16.7. Cuando una ciudad es ocupada, entonces se rasura; cuando una mujer está de luto, entonces renuncia a la belleza de su cabeza; y el hambre procede de la tierra cuando no está frondosa.

16.8. Pero a un árbol caído se le llora, y un poeta puede sobre él entonar elevados cantos, mientras que tú, tras cortar tus hojas, no derramas ni una lágrima. Déjame que te diga el epitafio de tu cabellera: ¡Ay, acrópolis de la belleza, sagrado recinto del amor! ¡Ay, estrellas de la cabeza! 


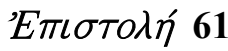

\section{Гvvaıkí}

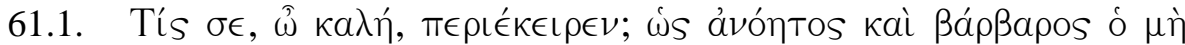

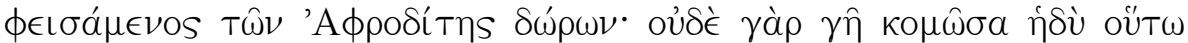

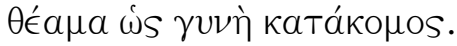

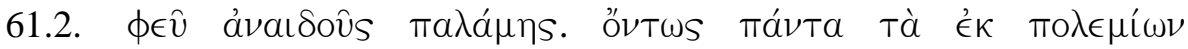

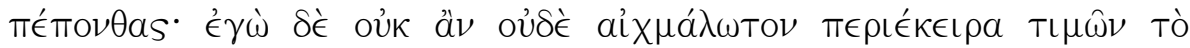

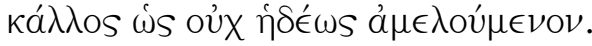

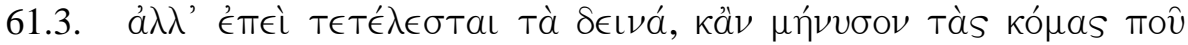

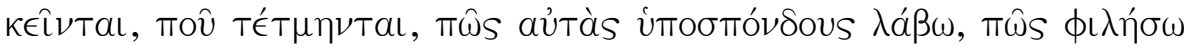

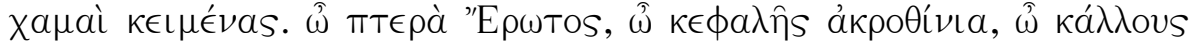
$\lambda \in i ́ \psi \alpha \nu a$. 


\title{
Carta 61
}

\begin{abstract}
A una mujer
61.1. ¿Quién te ha rapado, preciosa mía? ¡Cuán absurdo y bárbaro es aquel que no cuida los dones de Afrodita! Pues ni siquiera la tierra cuando está frondosa es una visión tan agradable como una mujer de larga melena.

61.2. ¡Ay de esa mano impúdica! Has padecido completamente todos los sufrimientos que causan los enemigos de guerra. Yo no hubiera rapado siquiera a una cautiva, puesto que honro tanto la belleza que no la maltrataría con gusto.

61.3. Pero una vez llevado a cabo este horror, di al menos dónde yacen tus cabellos, dónde han sido cortados, cómo puedo recogerlos bajo tregua, cómo besarlos mientras yacen por tierra. ¡Ay, alas de Eros! ¡Ay primicias de la cabeza! ¡Ay reliquias de la belleza!
\end{abstract}




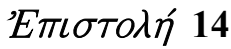

\section{Meıрakí}

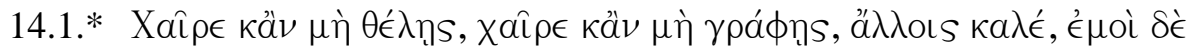

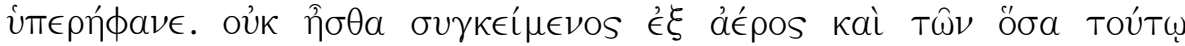

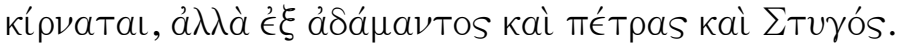

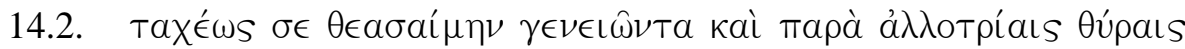

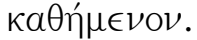

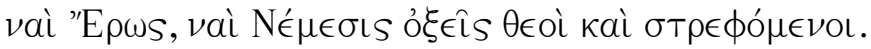




\title{
Carta 14
}

\begin{abstract}
A un muchacho
14.1.* Te saludo, aunque no quieras. Te saludo, aunque no me escribas. Bien con otros te portas y a mí me desprecias. No estás hecho de aire y de lo que con él se mezcla, sino de hierro, piedra y agua de la Estigia.

14.2. Espero verte pronto cubierto de barba y haciendo guardia ante las puertas de otros.
\end{abstract}

Así sea, por Eros y por Némesis, raudos y tornadizos dioses. 


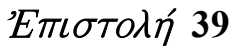

\section{Гvvaıkí}

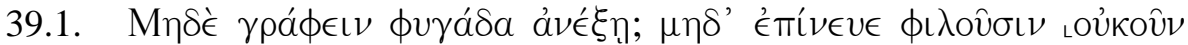

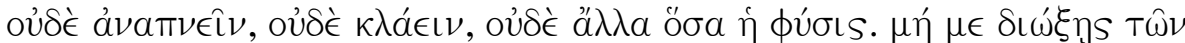

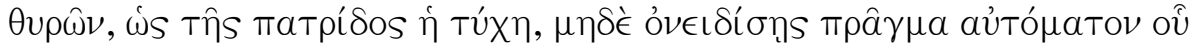

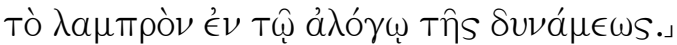

39.2. Ёф

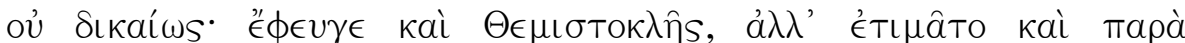

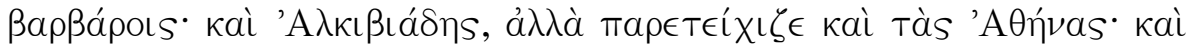

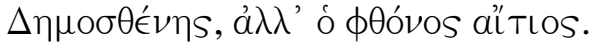

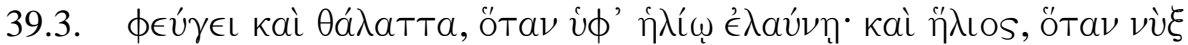

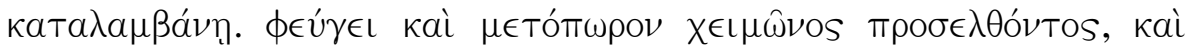

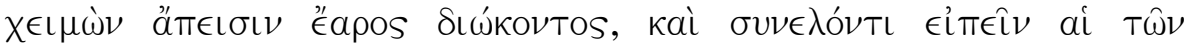

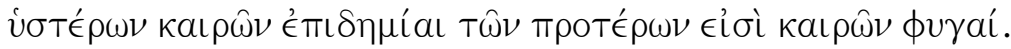

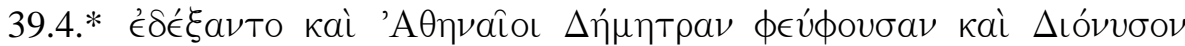

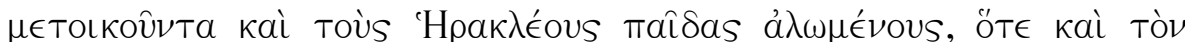

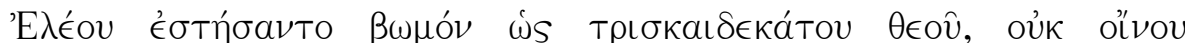

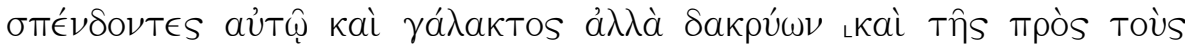

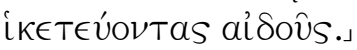

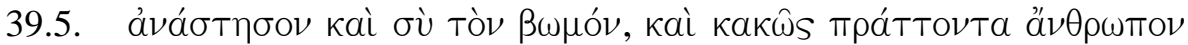

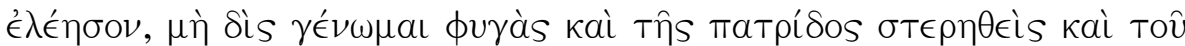

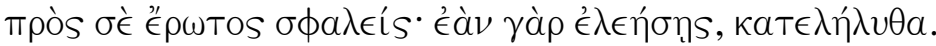




\title{
Carta 39
}

\begin{abstract}
A una mujer
39.1. ¿Es que ni siquiera vas a permitir a un exiliado que te escriba? Entonces no consientas a los que aman ni respirar siquiera, ni llorar, ni nada de lo que es natural. No me expulses de tus puertas, como de mi patria la suerte, ni me reproches un acto espontáneo cuya explicación reside en un poder irracional.
\end{abstract}

39.2. También Arístides estuvo exiliado, pero regresó; y Jenofonte, mas de una forma injusta; fue exiliado igualmente Temístocles, pero recibió honores incluso entre los bárbaros; y Alcibíades, pero levantó las murallas de Atenas; y Demóstenes, mas por culpa de la envidia.

39.3. Huye también el mar, cuando es arrastrado por el sol; y el sol, cuando cae la noche; huye asimismo el otoño, porque se acerca el invierno; y parte el invierno perseguido por la primavera; en una palabra, la llegada de las nuevas estaciones supone la huida de las anteriores.

39.4.* Además, los atenienses acogieron a Deméter en su exilio, también a Dioniso en uno de sus viajes y a los hijos de Heracles, que vagaban desterrados: entonces erigieron los atenienses un altar a la Piedad, como decimotercera divinidad, a quien no hacían libaciones con vino y leche, sino de lágrimas y respeto ante los suplicantes.

39.5. Levanta también tú este altar y ten piedad de una persona desdichada, para que no me convierta en un doble exiliado, privado de mi patria y desposeído de mi amor por ti: pues, si te apiadaras, retornaría a mi hogar. 


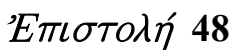

\section{Meıракí}

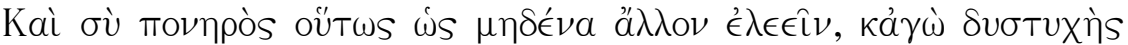

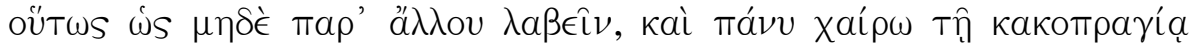

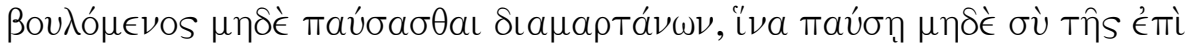

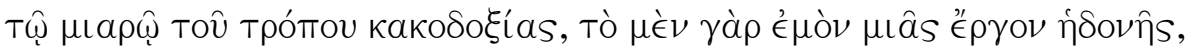

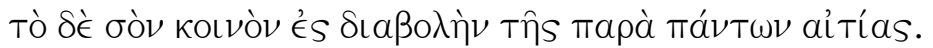




\title{
Carta 48
}

\begin{abstract}
A un muchacho
Tú eres tan cruel que no puedes sentir piedad por nadie; y yo tan desdichado que de ningún otro la puedo recibir: y bien que me regocijo en mi desdicha, con el deseo de no cesar en mi equívoco, para que no ceses tú de tener mala reputación debido a lo infame de tu carácter: pues lo mío es un acto de placer, pero lo tuyo es un acto público motivo de calumnia común.
\end{abstract}





\section{COMENTARIO}

\section{Carta 5}

5.1. El final de la primera frase aparece de forma muy similar en los

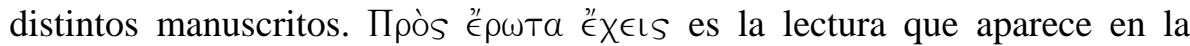
llamada familia 1 de manuscritos, aunque su forma más frecuente en esa familia es con el acusativo plural épwtas y así lo edita C. L. Kayser y

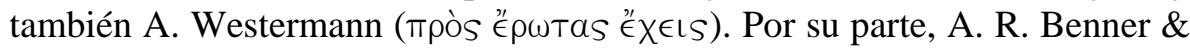

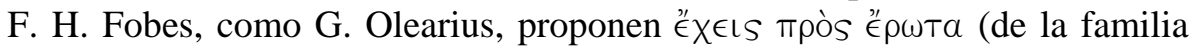
2), forma con la que se evita el encuentro de vocales de distintas palabras (aunque ya se ha comentado que estaba permitido cuando estas eran breves),

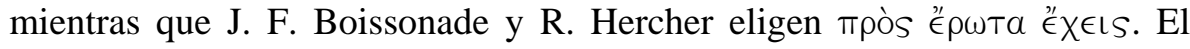
plural "́pwtas de C. L. Kayser puede obedecer también a ese intento de evitar el contacto de vocales, además de ser la forma más frecuente en la mejor familia de códices para este editor, quien quizá la eligió por ser la forma plural de este nombre la que se empleaba en griego para designar los «amores» de forma abstracta, ${ }^{270}$ y quizá también porque este pasaje de Filóstrato puede reflejar cierto eco de un diálogo lucianesco, en el que, tras

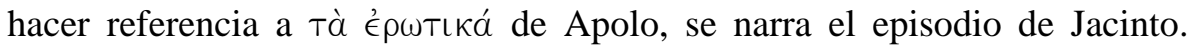
Precisamente la idea de relacionar la insensibilidad al amor (Carta 5.1 oútws

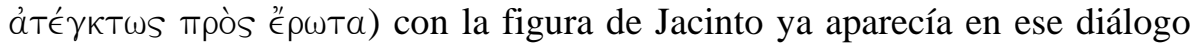
(Diálogos de los dioses 14.1) cuando Hermes pregunta al triste Apolo: î rís

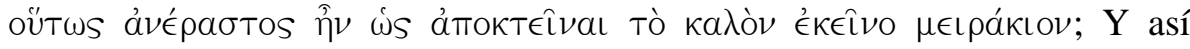
explica Apolo cómo ha hecho brotar la flor del jacinto de la sangre de la herida que él mismo le ha infligido accidentalmente a su amado. Pero también en las obras de Filóstrato se encuentran referencias a este tema en las Imágenes (I 24.1), donde se recuerda que en la Antigüedad se consideraba que en la flor del jacinto se leían las letras AI, procedentes,

270 Aunque en la colección de Cartas suele emplearse el singular también para hacer referencia al amor como nombre abstracto. 
según se decía en ocasiones, de la expresión de duelo aỉaî, como podemos leer, por ejemplo, en el Epitafio de Bión atribuido a Mosco (III 6: vv̂v

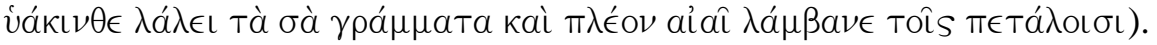

\section{Carta 47}

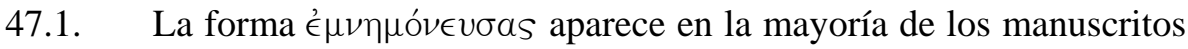
de la familia 1 (y así la reproducen G. Olearius, J. F. Boissonade, C. L. Kayser, A. Westermann y R. Hercher), mientras que el otro grupo de manuscritos principalmente escribe $\epsilon ́ \mu \nu \eta \mu o ́ v \epsilon v \sigma \alpha$, lectura que eligen los editores R. Benner \& F. H. Fobes (ya se ha comentado que tienden a preferir el texto que contiene esta familia 2, de forma esencialmente contraria a la edición de C. L. Kayser). En este caso parece conveniente la segunda persona del singular, más acorde tanto con el contenido de la Carta 47 como con la de su compañera 5 , en las que estas expresiones van dirigidas todas a

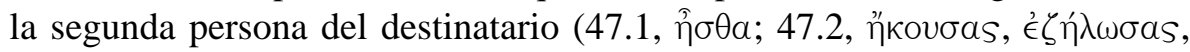

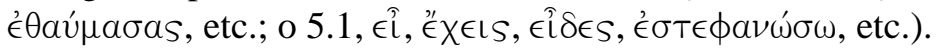

\section{Carta 7}

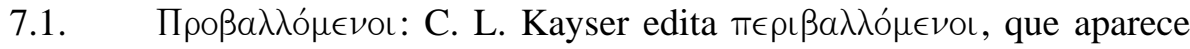
en manuscritos de la familia 1 (algunos de los cuales no tienen el siguiente

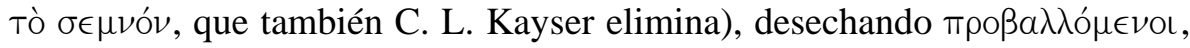
que aparece en ambas familias, lectura que eligen G. Olearius, J. F. Boissonade o A. R. Benner \& F. H. Fobes; R. Hercher edita tòv Toגùv

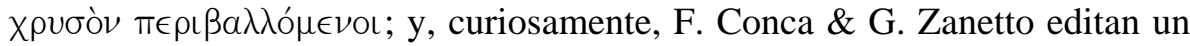
híbrido, $\pi \in \rho \iota \beta a \lambda \lambda o ́ \mu \in \nu$ ol tò $\sigma \in \mu \nu$ óv. La aparición de $\pi \rho \circ \beta a \lambda \lambda o ́ \mu \in \nu$ ol en los manuscritos de ambas familias y su adecuación al sentido del pasaje parecen sustentar suficientemente su elección, mientras que la forma $\pi \epsilon \rho \iota \beta a \lambda \lambda o ́ \mu \in \nu \circ$

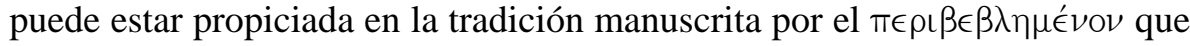
aparece pocas líneas antes.

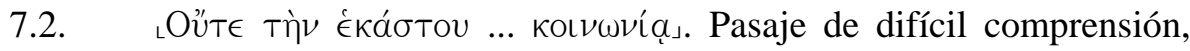
recogido solo por la segunda familia de manuscritos. Los editores realizan distintas interpretaciones y correcciones: G. Olearius explica «sensus mihi iste videtur: fortunam curae non habere ut omnium hominum querelis satisfaciat, eorumque adversus se criminationibus absolvatur; neque iis

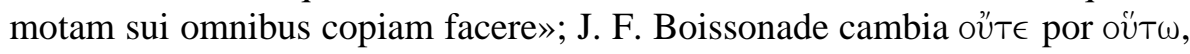


«sic unius cuiusque crimina fortuna diluit, mutuo pauperis ac divitis consortio»; C. L. Kayser en su edición de 1844 señala que falta texto tras oúte (lo mismo indica A. Westermann) y en la de 1870-71 añade tras ese

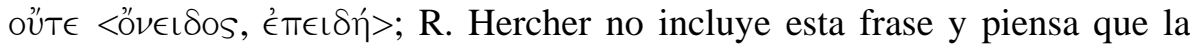
anterior también debería eliminarse; A. R. Benner \& F. H. Fobes traducen este pasaje «nor does the individual's fortune excuse his fault in our relations with one another»; y la más reciente edición de F. Conca \& G. Zanetto, «né la sorte libera ciascuno dalle proprie colpe attraverso le reciproche relazione». En nuestra traducción, que no modifica el texto de los manuscritos, se recoge el sentido que el verbo ảmoגúw en voz media más el acusativo aítíav solía tener en griego clásico; vid., por ejemplo, Th. V 75.3.

\section{Carta 28}

28.3. C. L. Kayser considera la existencia de una laguna tras tòv ék

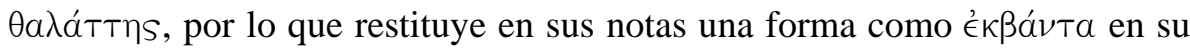
edición de 1844 o ïкоvтa en la de 1870-71, laguna que también R. Hercher recoge. Sin embargo, no es en absoluto necesario restituir ningún término, como hacen R. Benner \& F. H. Fobes, ya que puede simplemente pensarse que sigue haciendo uso del anterior participio тарóvтa que se refiere a Paris, aplicado en el siguiente miembro a Demofonte; además, el empleo del verbo $\pi \alpha ́ \rho \in \iota \mu \iota$ indicando procedencia era habitual y está sancionado, por ejemplo, en el léxico de H. G. Liddell \& R. Scott \& alii, 1996 (s.v. I 6).

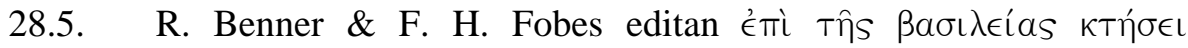
(atribuyen en sus notas la corrección a Valckenaer), en lugar de la lectura

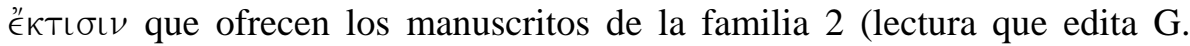

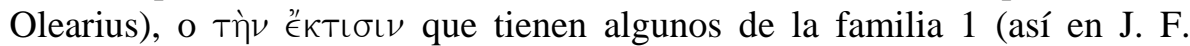
Boissonade, C. L. Kayser, A. Westermann, R. Hercher), si bien hay manuscritos que omiten esta palabra. Sin embargo, no parece necesario cambiar un término presente en muchos de los códices, aunque no sea una forma aparentemente muy frecuente en los textos conservados, y que puede estar utilizado en el sentido de 'pago' o 'recuperación' (como el verbo ÉkTí $\nu(\omega)$. Adrasto casó a sus hijas con Polinices y Tideo, con la promesa de restituirlos a sus patrias -de las que habían sido expulsados-, Tebas y Calidón, comenzando por la primera, que dio lugar a la famosa expedición de los Siete contra Tebas. 


\section{Carta 12}

12.3. Kатаגıтойбav es la propuesta de R. Hercher que R. Benner \& F. H. Fobes aceptan para su edición (porque resuelve los problemas de sentido y además concuerda con la Carta 29.3, en la que el alma abandona al astro en pos de amores terrenales). Sin embargo, hay dos lecturas en los

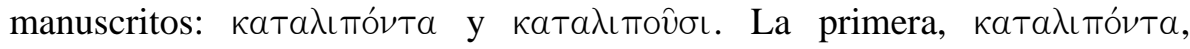
pertenece a algunos códices de la familia 1 y es la que publican J. F. Boissonade, C. L. Kayser y A. Westermann, ${ }^{271}$ pero es mucho más frecuente

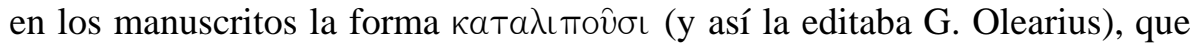
puede hacer referencia al anterior

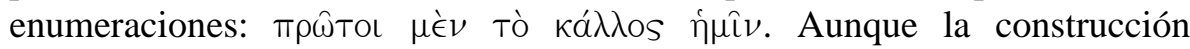
habitual en griego es con el acusativo (vid. H. G. Liddell \& R. Scott \& alii,

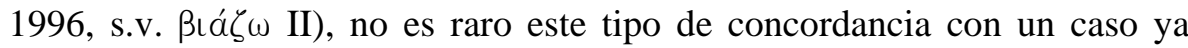

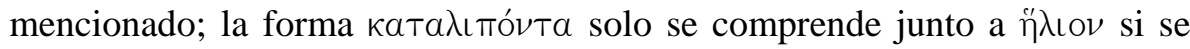
piensa en un elidido pronombre personal $\mu \epsilon$. Dado que el pronombre expresado tiene forma de dativo, que la construcción no carece de sentido y que se halla en gran número de códices, parece preferible mantener esa forma de dativo plural, aunque tampoco iría mal en el pasaje el acusativo

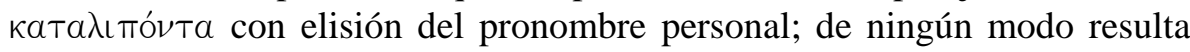

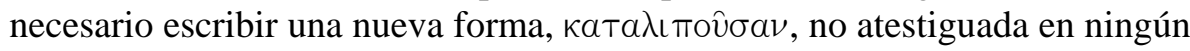
manuscrito.

\section{Carta 29}

29.3. Este verso lo pronuncia Ayante en el Canto XXIII de la Ilíada cuando se enfrenta a Odiseo en la prueba del pugilato. La pelea dura ya demasiado y Ayante propone que aquel que pueda levantar por los aires al otro será el vencedor (v. 724). Sin embargo, en los versos homéricos pelean por un gran trípode que se llevará el primero (vv. 700 ss.), mientras que al perdedor le corresponderá una mujer, que es, en la Carta, precisamente el premio de los rivales en amores, quienes, sin duda, pugnan por la atención de la amada.

\footnotetext{
271 Su traducción al latín reza: «primi coegistis misso sole alienum laudare ignem», la

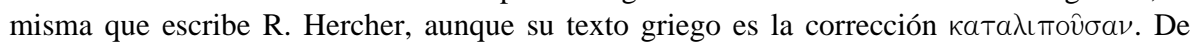
todos modos, la traducción no se corresponde con ninguna de las versiones griegas, puesto que en ambos casos el participio es activo.
} 


\section{Carta 24}

24.1. Estos versos proceden del Canto II de la Ilíada (vv. 478-479). En ellos describe Homero un Agamenón al que Zeus hace sobresalir y destacar por encima de los demás ${ }^{272}$ cuando se halla al frente de las tropas en los instantes previos al combate.

\section{Carta 25}

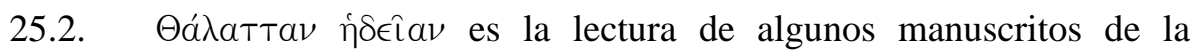
familia 1 y que C. L. Kayser utilizaba en su edición de 1844 de las Cartas. Sin embargo, este pasaje es editado de muy diferentes maneras. Una propuesta (de Cobet) que tanto R. Benner \& F. H. Fobes como C. L. Kayser,

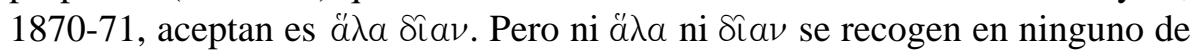
los manuscritos, sino que aparece $\theta a ́ \lambda a \tau \tau a \nu$, bien sola, bien acompañada del adjetivo $\dot{\eta} \delta \in \hat{i} \alpha \nu$, como ya se ha comentado. R. Hercher decide aceptar

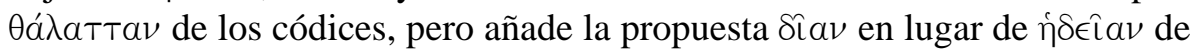
algunos manuscritos. En este caso, dado que la tradición nos ofrece

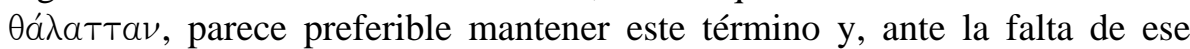
adjetivo que lo califique (como en el resto de elementos de que consta el pasaje), preferimos tomar una forma atestiguada, $\dot{\eta} \delta \in \hat{\imath} \alpha \nu$, antes que la interpretación $\delta i a v$, que tenía sentido si se pensaba que $\theta a ́ \lambda a \tau \tau a v$ a solas

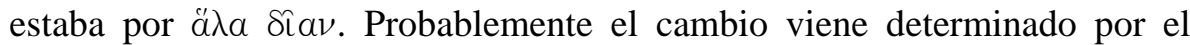
inevitable recuerdo del giro homérico $\epsilon i s$ ă $\lambda \alpha$ Siav (Il. I 141, II 152; Od. III 153, IV 577, V 261, VIII 34, XI 2), que realmente resulta apropiado también en este pasaje, si bien no puede negarse que asimismo $\theta a ́ \lambda a \tau T a$ puede ser descrito como algo agradable y hermoso, y así lo encontramos en las

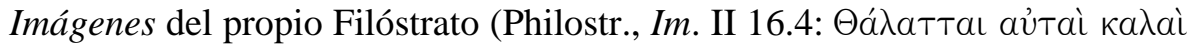

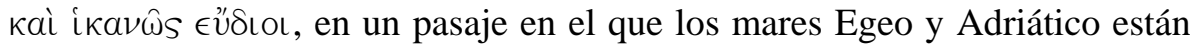
representados por dos muchachas). No hay que pasar por alto tampoco que se comparan opuestos en este pasaje: la luna brillante u oscurecida por las nubes, Afrodita hermosa o furiosa y llorando, etc., por lo que tiene gran

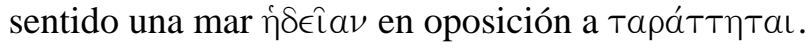

\footnotetext{
272 Vid. los versos 482-483:

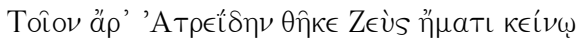

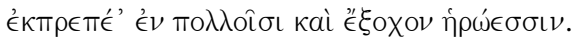

Así, en efecto, presentó Zeus al Atrida aquel día distinguido y exquisito entre muchos héroes.
} 


\section{Carta 57}

57.1. El principio de la Carta contiene dos pasajes de difícil interpretación. El primero de ellos parte del texto conservado: [...] ỏ

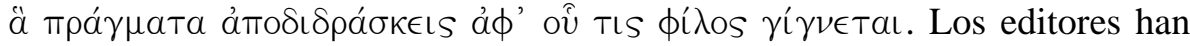
ido modificando de diversa manera estas palabras. G. Olearius cambia en su edición $a \dot{\phi}$ ' ôे por el plural $a \dot{\phi}$ ' $\hat{\omega} \nu$, de modo que se obtiene cierta

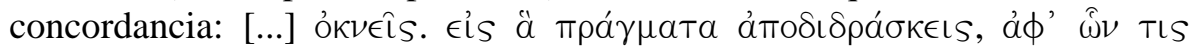

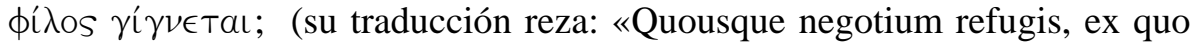
amicus tibi paratur?»). J. F. Boissonade no acepta el cambio de G. Olearius ni su interpretación y considera $\alpha \phi^{\prime}$ ov̂ un giro adverbializado, al estilo del

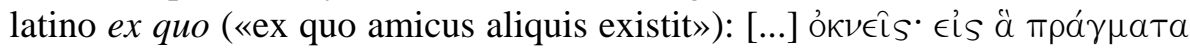

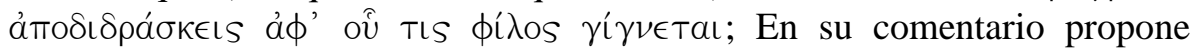

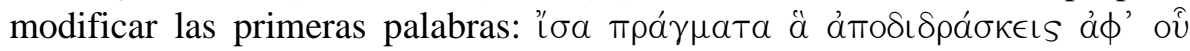
[...]. C. L. Kayser, en su edición de 1844, conjetura lo siguiente: [...] ỏkveîs

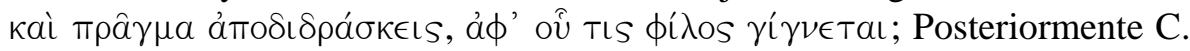
L. Kayser, 1870-71, aceptará la propuesta de A. Westermann, que también

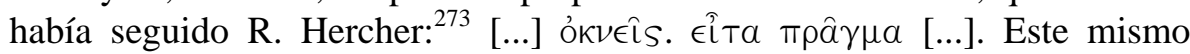
texto aceptarán finalmente A. R. Benner \& F. H. Fobes: [...] ỏkveîs. €îta

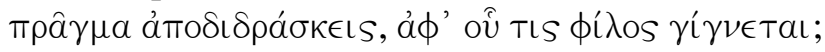

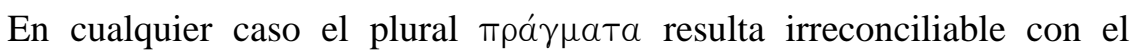
singular $\alpha \dot{\phi}$ ' ố, e inevitablemente hay que corregir una de las dos formas. Con la solución adoptada por los últimos editores es la primera sección la que se modifica ( $\epsilon \hat{\imath} \tau \alpha \pi \rho \hat{\alpha} \gamma \mu \alpha$ por $\epsilon i s ~ a ̊ ~ \pi \rho a ́ \gamma \mu \alpha \tau \alpha)$, pero si atendemos a parte de una idea de J. F. Boissonade, que $\epsilon i s$ ä se halle por " debe alterarse (como ya sospechaba G. Olearius) el número del pronombre:

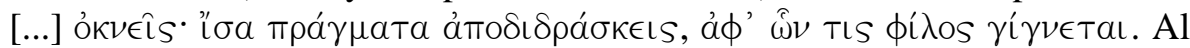
adjetivo $\iota \sigma \alpha$ le sigue una construcción con relativo, como es habitual para este término (vid., por ejemplo, G. Liddell \& R. Scott \& alii, 1996, s.v. ťoos, I 1). A pesar de lo arriesgado de realizar esta propuesta a través de los escasos datos del texto de los manuscritos que tenemos y a la espera de la necesaria publicación de una edición moderna y exhaustiva, dicha propuesta nos parece interesante y aceptable.

El otro pasaje conflictivo se refiere a los genitivos de la tradición textual,

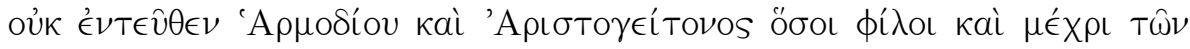

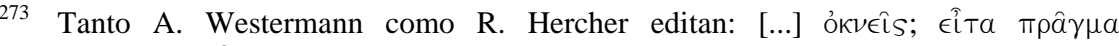

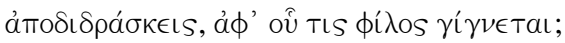


$\xi\llcorner\phi \omega \hat{\nu}$. La puntuación de G. Olearius no agrada a los posteriores editores:

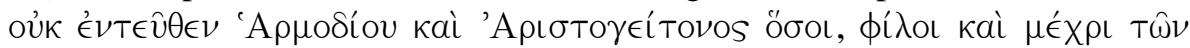
$\xi\llcorner\phi \omega v \nu ;$ J. F. Boissonade la critica, conserva los genitivos pero elimina la coma tras ö $\sigma o l$, sin comentar nada del caso de los nombres propios y

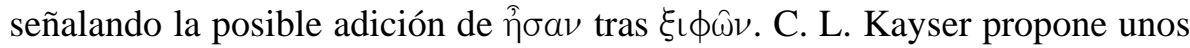
nominativos plurales que admitirán los editores posteriores, así como la

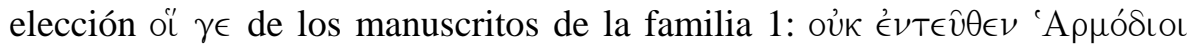

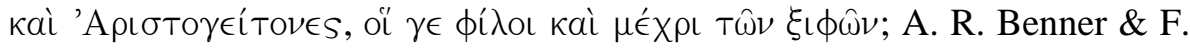
H. Fobes señalan la elección oí $\gamma \in$ de C. L. Kayser por aparecer en la familia

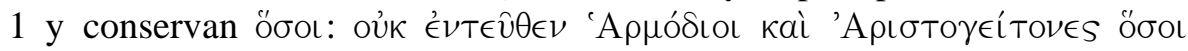

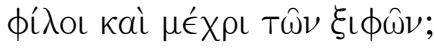

De la misma manera que en el anterior punto, se sugiere ahora una modificación arriesgada: los manuscritos cotejados por estos editores presentan siempre las formas de genitivo, pero ello confiere escaso sentido al texto, por lo que aquí se ha buscado una solución basada en las propias Cartas de Filóstrato y en el sentido de estas figuras, Harmodio y Aristogitón.

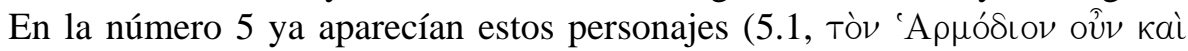

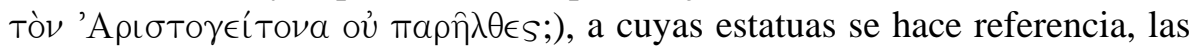
que Clístenes encargó al escultor Antenor (o a la copia que posteriormente realizaron Critias y Nesiotes) para honrar a los héroes tiranicidas (sobre ella puede leerse más información ${ }^{274}$ en Th. VI 53-59, Arist., Ath. 18, Paus. I 8.5, Arr., An. III 16.8), si bien en ambos casos Filóstrato las emplea como símbolo del amor homosexual. Pues bien, al igual que en la Carta 5, hace ahora referencia el autor a las estatuas con la intención de que el lector las imagine visualmente, ${ }^{275}$ como hacía en la otra misiva, para lo cual simplemente corregiríamos el adverbio $\epsilon^{\prime} \nu T \in \hat{v} \theta \in \nu$ por una forma como

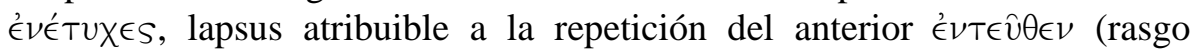
estilístico no ajeno a estas Cartas, como puede comprobarse en la reiteración de oûv en la misma Carta 5.1). Además, resulta preferible en este contexto la lectura de la familia 1 que C. L. Kayser editaba, oi $\gamma \in$, en lugar de öбos:

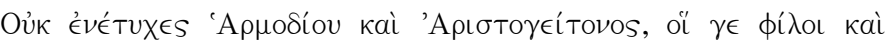
$\mu \epsilon ́ x \rho \iota \tau \hat{\omega} \nu \xi \iota \phi \hat{\omega} \nu$

274 Para más detalles acerca de su forma original, de su ubicación, de las más importantes representaciones artísticas y de su mención en distintos autores, vid. el comentario a la obra de Pausanias a cargo de J. G. Frazer, 1898, pp. 92 ss.

275 El gran número de reproducciones artísticas de este conjunto escultórico en diversas formas y soportes da cuenta de la fama que rodeaba al original; cf. J. G. Frazer, 1898, pp. 94 ss. 


\section{Carta 26}

26.1. G. Olearius y A. R. Benner \& F. H. Fobes editan la corrección de

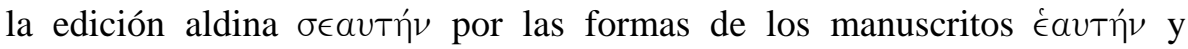
баvтท́ $v$. J. F. Boissonade, C. L. Kayser y A. Westermann se decantan por la forma aparentemente más frecuente en los códices, éavтท́v; mientras que R. Hercher escribe бavтńv (probablemente por ser esta una forma propia del ático).

El uso de la forma propia de la tercera persona para las otras dos está sancionado en lengua griega, tanto en época clásica como en las posteriores, y se empleará en la koiné literaria y en la coloquial, ${ }^{276}$ así como en los autores aticistas: es, de hecho, un uso habitual en los textos de Filóstrato. ${ }^{277}$ Por ello parece preferible mantener la forma de los manuscritos, éavtív. La corrección de la forma por $\sigma \in a v T \eta ́ v$ se ha podido ver propiciada por la similitud con casi la misma expresión en la Carta 25.4.

\section{Carta 16}

16.4. Tenemos Öா Tors en manuscritos de la familia 2; sin embargo, en la familia 1 aparece mí $\lambda$ ors, cuyo significado básico es 'fieltro', el que se empleaba para determinados gorros o zapatos. Parece que es el material con el que se hacían determinados tocados persas, que podían indicar la categoría social en función de la cantidad de adornos que llevaran (Hdt. III 12, VII 61 y $62,{ }^{278}$ vid. C. Schrader, 1977-1989, ad loc.; en VII 92 hace referencia a unos gorros decorados con plumas que usaban los licios); en el léxico de $\mathrm{H}$. G. Liddell \& R. Scott \& alii, 1996 (s.v. Tî̀os) se indica, además, que puede aludir al cabello humano (Pl., Lg. 942E). Además, tal y como indica G. Olearius acerca de este pasaje, hay varias referencias en la Antigüedad que coinciden con el texto de Filóstrato, como se lee en un epigrama de Marcial (Mart. X 72.4: ad Parthos procul ite pilleatos, edición de D. R. Shackleton Bailey, 1990). Quizá el desconocimiento del significado exacto de mî̀os durante la transmisión de los textos hizo que algún copista, conocedor de la

276 E. Mayser, 1970, pp. 63 s.; L. Radermacher, 1947, p. 42; G. N. Hatzidakis, 1977, pp. 189 s.; F. Blass \& A. Debrunner \& F. Rehkopf, 1979, p. 50.

277 W. Schmid, 1964d, pp. 15, 69 s.

278 Vid. R. W. Macan, 1908, ad loc. VII 61.1, quien comenta la dificultad para conocer con exactitud qué tipo de tocado sería este mî̀os; quizás puede afirmarse con cierta seguridad que su material sería el fieltro o similar.

Monografías de Filología Griega 20. ISSN 1136-0860 


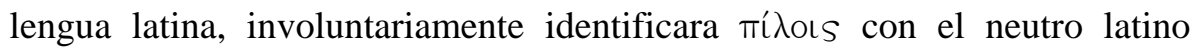
pilum, ${ }^{279}$ arma arrojadiza característica del soldado romano, y escribiera en su lugar ötrioss, con lo que el pasaje se desprendía de un término de significado indeterminado, míloss, y se quedaba con uno mucho más sencillo y no carente de sentido, 'armas'. Sin embargo, una vez desvelado de forma aproximada el sentido de tínoıs, resulta mucho más acorde con el pasaje, en el que, en efecto, se compara el aspecto de los persas y sus propios gorros de fieltro, con el de los griegos y sus característicos yelmos. De este modo editamos el mismo texto que publicaban G. Olearius, C. L. Kayser, A. Westermann o R. Hercher, en lugar del de J. F. Boissonade (oi $\mu \grave{\epsilon} \nu$ yà $\rho$

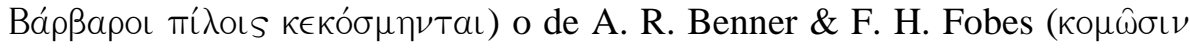

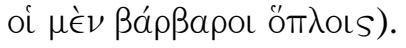

\section{Carta 14}

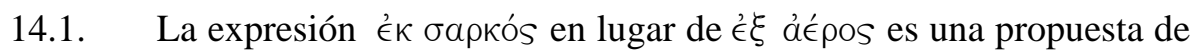
R. Bentley que adoptan J. F. Boissonade, C. L. Kayser, R. Hercher y A. R. Benner \& F. H. Fobes. Para ello, la relacionan con un pasaje del Protágoras de Platón en el que se menciona la mezcla de tierra y fuego como origen de los seres vivos $\left(\theta \nu \eta+\grave{a} \gamma^{\prime} \nu^{\prime} \eta\right) .{ }^{280}$ Asimismo C. L. Kayser sugiere una laguna

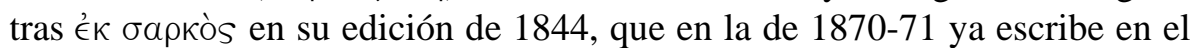

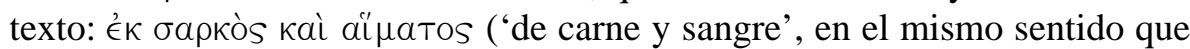
nuestro 'de carne y hueso'), adición que R. Hercher aplaude en sus notas y la sustenta en el mencionado texto platónico (Pl. Prt. 320 D). En este trabajo nos quedamos con la forma transmitida, como hacía G. Olearius, é $\xi$ défoos, que tampoco carece de sentido y puede, además, relacionarse con un fragmento de Anaxímenes (13 Anaximenes B 2, H. Diels \& W. Kranz):

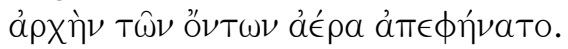

279 Piénsese, además, en la coincidencia con el término latino pilus, que significa 'pelo', ‘cabello'.

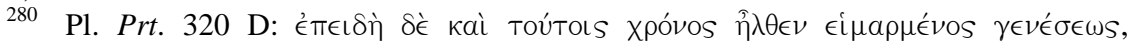

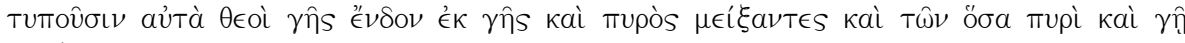

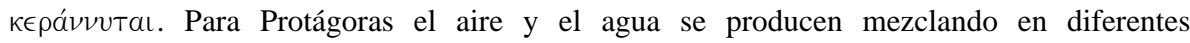
proporciones los otros dos elementos, el fuego y la tierra; vid. Tim. 42 E, que J. Adam \& A. M. Adam, 1960, señalan a raíz de este pasaje. 


\section{Carta 39}

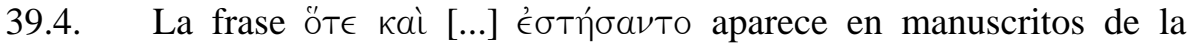
familia 1, y es la lectura que eligen casi todos los editores más recientes (J. F. Boissonade, C. L. Kayser, A. Westermann, R. Hercher), mientras que A. R. Benner \& F. H. Fobes, como G. Olearius, editan Öтav кaì. Si bien es cierto que en la lengua común existía un uso de öт $\alpha \nu$ más indicativo, este es bastante reducido y en ningún caso responde a un empleo generalizado. ${ }^{281}$ Los autores clasicistas y después los aticistas cuidarán mucho la corrección en este punto, que W. Schmid considera uno de los vulgarismos más bajos. ${ }^{282}$

281 Por ejemplo, aparece en el Nuevo testamento para expresar una espera o expectativa; vid. F. Blass \& A. Debrunner \& F. Rehkopf, 1979, pp. 309 s. En la koiné se aprecia cierta tendencia a confundir subjuntivo e indicativo en algunas construcciones (con

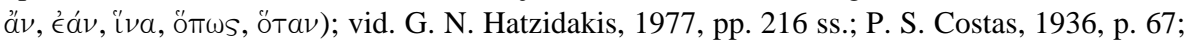
F. Blass \& A. Debrunner \& F. Rehkopf, 1979, pp. 288 ss.; M. García Teijeiro, 1983, p. 269.

282 Cf. W. Schmid, 1964b, p. 60, y 1964d, pp. 90 y 621. 
INDEX VERBORUM

Aftonio

Progymnasmata 12, 27, 32, 42, 53, 64

Alcifrón

Cartas 15, 31, 78, 79, 84

Anaxímenes de Lámpsaco

Retórica a Alejandro 12, 21, 26, 31, 43, 44, 49, 52, 53

Anaxímenes (filósofo del siglo VI a. C.) 151

Anónimo Segueriano 22, 29, 33, 34, 42, 43, 44, 48, 49, 53, 57, 59, 74

Antípatro de Hierápolis 20, 25, 74

Apsines de Gádara (Apsines el Fenicio)

Retórica 12, 22, 31, 43, 44, 46, 47, 48, 49, 50, 51, 52, 53, 54, 55, 56, 58, 59, 74,71

Aristides (Ps.)

Arte retórica 23, 61, 62, 64, 72, 75

Aristóteles

Retórica 12, 21, 22, 29, 30, 31, 33, 34, 35, 36, 39, 40, 41, 43, 44, 46, 49, 52, 53 $56,57,58,61,62$

aticismo 65-69, 150, 152

Caracteres epistolares 12, 24, 25, 71, 76

Carta a Aspasio de Ravena

vid. Filóstrato de Lemnos

Cornuto 22

Damiano de Éfeso 20

Demetrio 24

vid. también Sobre el estilo y Tipos epistolares 
destinatario 19, 31, 32, 33, 35, 36, 37, 38, 39, 40, 41, 43, 44, 47, 49, 51, 52, 54, 55, $61,74,76,77,78,79,85,86,144$

Eliano

Cartas 15, 36, 78, 79

etopeya 16, 29, 30, 31, 32, 33, 42, 44, 53, 64, 71, 73

Filóstrato 14, 19, 21, 22, 23, 25, 29, 43, 56, 65, 66, 67, 70, 74, 75, 77, 84, 143, 147

Cartas 11, 12, 13, 15, 16, 19, 25, 31, 35, 36, 37, 38, 42, 49, 50, 51, 55, 56, 61, 62, 63, 65, 66, 67, 69, 70, 74, 75, 77, 78, 79, 83, 84, 143, 149, 150

los distintos «Filóstratos» 11, 19

Gimnástico 11, 19

Imágenes 143, 147

Vida de Apolonio de Tiana 11, 19, 25

Vidas de sofistas 11, 12, 19, 21, 22, 23, 25, 26, 74

Filóstrato de Lemnos

Carta a Aspasio de Ravena 11, 12, 19, 24, 25, 26, 31, 64, 65, 69, 71, 83, 84

género epistolar 11, 15, 16, 24, 25, 29, 30, 31, 40, 42, 57, 62, 64, 72, 73, 74, 75, 77, 78, 79

Gregorio de Nacianzo 25, 64, 71

Hermógenes de Tarsos

Sobre las formas de estilo 12, 23, 27, 31, 40, 41, 46, 47, 58, 60, 61, 62, 63, 64, 69, 70, 72, 73, 75

Hermógenes (Ps.)

Progymnasmata 12, 23, 27, 30, 32, 33, 42, 53

koiné 65, 67, 68, 69, 150, 152

Libanio 24, 27, 32

Longino

vid. Sobre lo sublime

Longo de Lesbos

Dafnis y Cloe 31

Nicágoras de Atenas 22

Nicolao de Mira

Progymnasmata 12, 27, 30, 32, 33, 42, 44, 53, 72

Proclo 24

Proclo de Náucratis 20 
prosopopeya $16,29,35$

remitente $31,32,35,36,37,38,39,40,41,46,48,49,50,52,54,55,56,60,62$, $63,77,78,79$

Segunda Sofística 11, 15, 21, 25, 76, 79

Severo de Alejandría 32, 33

Sobre el estilo 12, 24, 31, 32, 57, 58, 59, 60, 61, 62, 63, 64, 65, 69, 71, 72, 73, 74, 75

Sobre lo sublime 12, 23, 46, 48, 57, 59, 61, 70, 74

Suda 11, 19, 20, 25

Teón, Elio

Progymnasmata 12, 26, 27, 29, 30, 32, 33, 34, 35, 39, 40, 73

Tipos epistolares 12, 24, 76

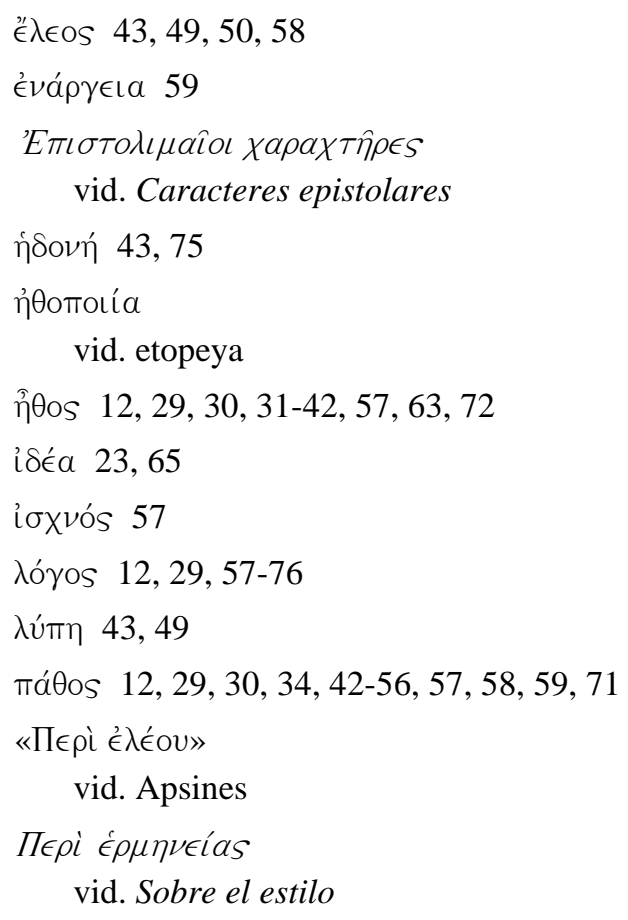


I $\epsilon$ i i $\delta \epsilon \epsilon \omega \nu$

vid. Hermógenes de Tarsos

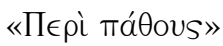

vid. Apsines

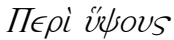

vid. Sobre lo sublime

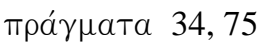

тре́тоv (тó) 29, 30

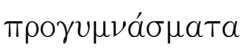

vid. Teón, Hermógenes, Aftonio, Nicolao

тробштотої́a

vid. prosopopeya

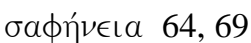

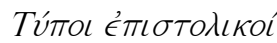

vid. Tipos epistolares

xapíels 62, 75

xápıs 60, 71, 75 


\section{BIBLIOGRAFÍA}

\section{Ediciones, traducciones y léxicos}

AdAm, J. \& ADAm, A. M., Platonis Protagoras, Cambridge, 1960.

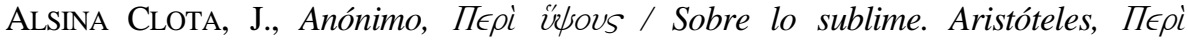

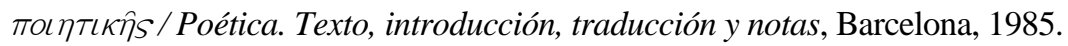

AujAC, G., Denys d'Halicarnasse, Opuscules rhétoriques: Les orateurs antiques, tomo I, París, 1978.

- Denys d'Halicarnasse, Opuscules rhétoriques: L'imitation, Première Lettre à Ammée, Lettre à Pompée Géminos, Dinarque, tomo v, París, 1992.

Aujac, G. \& LeBel, M., Denys d'Halicarnasse, Opuscules rhétoriques: La composition stylistique, tomo III, París, 1981.

BÉCARES Botas, V., Dionisio de Halicarnaso, La composición literaria. Traducción, notas e introducción, Salamanca, 1983.

Benner, A. R. \& Fobes, F. H., The Letters of Alciphron, Aelian and Philostratus, Cambridge (Massachusetts), 1962 (=1949).

BERnABÉ, A., Aristóteles, Retórica. Introducción, traducción y notas, Madrid, 1998.

BoIssonade, J. F., Philostrati Epistolae quas ad codices recensuit et notis Olearii suisque instruxit, París-Leipzig, 1842.

ButTs, J. R., The «Progymnasmata» of Theon: A new text with translation and commentary, Claremont Graduate School, 1986.

ChIRON, P., Démétrios: du style. Introduction, texte, traduction, París, 1993.

CONCA, F. \& ZANETTO, G., Alcifrone, Filostrato, Aristeneto. Lettere d'amore, Milán, 2005.

Dilts M. R. \& Kennedy, G. A., Two Greek rhetorical treatises from the Roman Empire: introduction, text, and translation of the Arts of rhetoric, attributed to Anonymous Seguerianus and to Apsines of Gadara, Leiden-Nueva YorkColonia, 1997.

FELten, I., Nicolai Progymnasmata, Leipzig, 1913.

FOERSTER, R., Libanii Opera: Progymnasmata, vol. VIII, Leipzig, 1915.

Frazer, J. G., Pausanias's Description of Greece, vol. II, Londres, 1898.

FuHRMAnN, M., Anaximenis Ars rhetorica quae vulgo fertur Aristotelis ad Alexandrum, Leipzig, 1966.

Gallé Cejudo, R. J., Aristéneto, Cartas eróticas: introducción, traducción y notas, Madrid, 1999. 
Hansmann, P., Des älteren Philostratos Erotische Briefe, nebst den Hetärenbriefen des Alkiphron, Fráncfort, 1989.

HerCher, R., Epistolographi Graeci, París, 1873.

KAYSER, C. L., Flavii Philostrati quae supersunt, Philostrati Iunioris Imagines, Callistrati Descriptiones, Zúrich, 1844.

- Flavii Philostrati Opera, 2 vols., Leipzig, 1870-1871.

Kennedy, G. A., Progymnasmata: Greek textbooks of prose composition and rhetoric, Leiden, 2003.

KYTZLER, B., Erotische Briefe der griechischen Antike, Múnich, 1967.

LidDell, H. G. \& ScotT R. \& StuART Jones H. \& McKenZIE R. \& et alii, A GreekEnglish Lexicon. With a revised supplement, Oxford, 1996.

MACAN, R. W., Herodotus. The seventh, eighth, \& ninth books, Londres, 1908.

OleArius, G., Philostratorum quae supersunt omnia, Leipzig, 1709.

Patillon, M., Progymnasmata. Aelius Théon, París, 1997 (1997a).

- Hermogène. L’Art rhétorique. Exercises préparatoires, États de cause, Invention, Catégories stylistiques, Méthode de l'habileté, Lausana, 1997 (1997b).

- Apsinès. Art rhétorique. Problèmes à faux-semblant, París, 2002 (2002a).

- Pseudo-Aelius Aristide. Arts Rhétoriques. Livre I: Le discours politique, tomo I; Livre II: Le discours simple, tomo II, París, 2002 (2002b).

- Anonymous Seguerianus. Art du discours politique, París, 2005.

- Corpus rhetoricum, París, 2008.

RABE, H., Rhetores Graeci, vol. vI: Hermogenis Opera, Leipzig, 1913.

- Rhetores Graeci, vol. x: Aphthonii Progymnasmata, Leipzig, 1926.

Ross, W. D., Aristotelis Ars rhetorica, Oxford, 1975 (=1959).

RusSELL, D. A., De sublimitate, Oxford, 1986 (=1968).

SCHRADER, C., Heródoto. Historia, vols. I-IX, Madrid, 1977-1989.

SHACKLETON BAiLeY, D. R., M. Valerii Martialis epigrammata, Stuttgart, 1990.

SPENGEL, L., Rhetores Graeci, vol. II, Leipzig, 1854.

SPENGEL, L. \& HAMMER, C., Rhetores graeci, vol. I, Leipzig, 1894.

WALZ, C., Rhetores Graeci, vol. I, Stuttgart-Tubinga, 1832-1836.

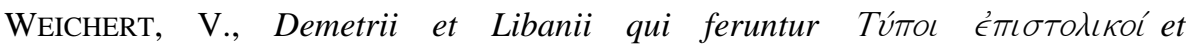

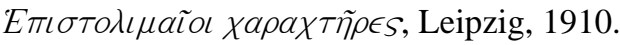

Westermann, A., Philostratorum et Callistrati Opera, París, 1878 (=1849).

Wooten, C. W., Hermogenes’ On types of style, Chapel Hill-Londres, 1987.

Wright, W. C., Philostratus and Eunapius. The lives of the Sophists, LondresCambridge (Massachusetts), 1961. 


\section{Estudios}

AltMAN, J. G., Epistolarity. Approaches to a Form, Ohio, 1982.

Амато, Е. \& SснамP, J. (eds.), 'Hөотої́a. La représentation de caractères entre fiction scolaire et réalité vivante à l'époque impériale et tardive, Salerno, 2005.

ANDERson, G., Philostratus: biography and belles lettres in the third century A. D., Londres, 1986.

- «The Pepaideumenos in action: sophists and their outlook in the Early Empire», ANRW, II 33.1, 1989, pp. 79-208.

Barrio Vega, M. ${ }^{\mathrm{a}}$ L. del, «Problemas de los grupos *k(h)y, *k ${ }^{\mathrm{u} 8}(\mathrm{~h}) \mathrm{y}, * \mathrm{t}(\mathrm{h}) \mathrm{y} \mathrm{y} * \mathrm{tw}$ en griego», $E M, 58,1990$, pp. 293-310.

BARWICK, K., «Die Gliederung der Narratio in der rhetorischen Theorie und ihre Bedeutung für die Geschichte des antiken Romans», Hermes, 63, 1928, pp. 261287.

Billault, A., L'Univers de Philostrate, Bruselas, 2000.

BirChaLL, J., «The lament as a rhetorical feature in the Greek novel», Groningen Colloquia on the novel VII, 1996, pp. 1-17.

BlAss, F., Die attische Beredsamkeit. Zweite Abtheilung: Isokrates und Isaios, Leipzig, 1892.

- Die attische Beredsamkeit. Dritte Abtheilung, erster Abschnitt: Demosthenes, Leipzig, 1893.

Blass, F. \& Debrunner, A. \& ReHKopf, F., Grammatik des neutestamentlichen Griechisch, Gotinga, 1979.

BOMPAIRE, J., Lucien écrivain. Imitation et création, París, 1958.

BowIE, E., "Philostratus: the life of a sophist", en E. Bowie \& J. Elsner, 2009, pp. 19-32.

- \& Elsner, J. (eds.), Philostratus, Cambridge, 2009.

BRINKMANN, A., «Der älteste Briefsteller», RhM, 64, 1909, pp. 310-317.

CLARK, D. L., Rhetoric in Greco-Roman education, Nueva York, 1957.

ClARKE, M. L., Higher education in the Ancient World, Londres, 1971.

CostaS, P. S., An outline of the history of the Greek Language. With particular emphasis on the Koine and the subsequent periods, Chicago, 1936.

Cribiore, R., Gymnastics of the Mind. Greek education in Hellenistic and Roman Egypt, Princeton-Oxford, 2001.

CUGuSI, P., «L'epistolografia: modelli e tipologie di comunicazione», en Lo spazio letterario di Roma Antica, II, Roma, 1990.

DENNiston, J. D., Greek prose style, Bristol, 2000 (=Oxford, 1952).

ElsNeR, J., «A Protean corpus», en E. Bowie \& J. Elsner, 2009, pp. 3-18. 
EXLER, F. X. J., The form of the ancient Greek letter. A study in Greek epistolography, Washington, 1923.

Flinterman, J.-J., Power, paideia \& pythagoreanism, Ámsterdam, 1995.

FoLLET, S., «Dédicataire et destinataires des Lettres de Philostrate», en J.-C. Fredouille \& M.-O. Goulet-Cazé \& alii (eds.), Titres et articulations du texte dans les æuvres antiques, Actes du Colloque International de Chantilly, 13-15 décembre 1994, París, 1997, pp. 135-147.

- «Éthopée, nouvelle, poème en prose: trois avatars de la lettre à l’Époque Impériale», en L. Nadjo \& E. Gavoille (eds.), Epistulae Antiquae I. Actes du I ${ }^{\text {er }}$ Colloque "Le genre épistolaire antique et ses prolongements», Université FrançoisRabelais, Tours, 18-19 septembre 1998, Lovaina-París, 2002, pp. 243-249.

GALLÉ CeJUDO, R. J., «La carta ficticia griega y el diálogo», ExcPhilol, 4-5, 199495, pp. 41-61.

- «Signos metalingüísticos referentes al marco formal en la epistolografía griega», Habis, 28, 1997, pp. 215-226.

- «Variaciones genéricas del anathematikón en las Cartas de Filóstrato», Minerva, 15, 2001, pp. 47-64.

GARCÍA LóPEZ, J., «Retórica y crítica literaria en época imperial», en J. A. López Férez (ed.), Historia de la literatura griega, Madrid, 1988, pp. 1005-1023.

García TeiJEIRO, M., «Innovaciones sintácticas en la koiné», en Unidad y pluralidad en el mundo antiguo, Actas del VI Congreso Español de Estudios Clásicos, I. Ponencias, Madrid, 1983, pp. 247-277.

GARZYA, A., «L’ epistolografia letteraria tardoantica», en C. Giuffrida \& M. Mazza (eds.), Le transformazioni della cultura nella tarda antichità. Atti del convegno tenuto a Catania, Università degli Studi, 27 sett.-2 ott. 1982, I, Roma, 1985, pp. 347-373.

GoLDHILL, S., «Constructing identity in Philostratus’ Love Letters», en E. Bowie \& J. Elsner, 2009, pp. 287-305.

GrEEN, L. D. \& MurPhy, J. J., Renaissance Rhetoric. Short-title catalogue 14601700, Aldershot-Burlington, Ashgate, 2006.

Grube, G. M. A., A Greek critic: Demetrius on style, Toronto, 1961.

HABIB, M. A. R., A history of literary criticism, Malden-Oxford-Victoria, 2005.

HAGEDORN, D., Zur Ideenlehre des Hermogenes, Gotinga, 1964.

HAGEN, H. M., 'Hөотоцía. Zur Geschichte eines rhetorischen Begriffs, ErlangenNúremberg, 1966.

HATZIDAKIS, G. N., Einleitung in die neugriechische Grammatik, HildesheimNueva York, 1977 (=Leipzig, 1892).

HEATH, M., «Theon and the history of the "Progymnasmata"», GRBS, 2002-2003, 43, pp. 129-160. 
Heusch, C., «Die Ethopoiie in der griechischen und lateinischen Antike: von der rhetorischen Progymnasma-Theorie zur literarischen Form», en E. Amato \& J. Schamp, 2005, pp. 11-33.

Hock, R. F. \& O’NeIL, E. N., The chreia in ancient rhetoric. Volume I. The Progymnasmata, Atlanta, Georgia, Scholar Press, 1986.

Horrocks, G., Greek. A history of the language and its speakers, Londres-Nueva York, 1997.

Humbert, J., Syntaxe grecque, París, 1960.

HungeR, H., Die Hochsprachliche profane Literatur der Byzantiner. Erster Band: Philosophie, Rhetorik, Epistolographie, Geschichtsschreibung, Geographie, Múnich, 1978.

INNES, D. C., «“Longino” y otros», en P. E. Easterling \& B. M. W. Knox (eds.), Historia de la literatura clásica (Cambridge University). Vol. I. Literatura griega, Madrid, 1990 (Cambridge, 1985), pp. 694-698

JENKinson, E. M., «Genus scripturae leve. Cornelius Nepos and the early history of biography at Rome», ANRW, I 3, 1973, pp. 703-719.

KENNEDY, G. A., The art of persuasion in Greece, Londres, 1963.

- The art of rhetoric in the Roman world, 300 B.C.-A.D. 300, Princeton, 1972.

- Greek rhetorik under Christian emperors, Princeton, 1983.

- (ed.), The Cambridge history of literary criticism, volume I, Classical Criticism, Cambridge, 1989.

- «The evolution of a theory of artistic prose», en G. A. Kennedy, 1989, pp.184-199.

- A new history of classical rhetoric, Princeton, 1994.

- «Historical survey of rhetoric», en S. E. Porter, 1997, pp. 3-41.

KoskenNiEmi, H., Studien zur Idee und Phraseologie des griechischen Briefes bis 400 n. Chr., Helsinki, 1956.

LANNOY, L. de, «Le problème des Philostrate (État de la question)», ANRW, II 34.3, 1997, pp. 2363-2449.

LeJeune, M., Phonétique historique du mycénien et du grec ancien, París, 1972.

LESKY, A., Historia de la literatura griega, Madrid, 1976 (Berna, 1963²).

López EIRE, A., Ático, koiné y aticismo. Estudios sobre Aristófanes y Libanio, Murcia, 1991.

- «Helenismo, Antigüedad tardía, retórica y epistolografía», en M. Brioso \& F. J. González Ponce (eds.), Actitudes literarias en la Grecia romana, Sevilla, 1998.

LÓPEZ GRIGERA, L., La retórica en la España del Siglo de Oro. Teoría y práctica, Salamanca, Universidad de Salamanca, 1994. 
MALHerbe, A. J., Ancient epistolary theorists, Atlanta, 1988.

MARGOLIN, J.-C., «La rhétorique d'Aphthonius et son influence au XVI ${ }^{\mathrm{e}}$ siècle», en R. Chevallier (ed.), Colloque sur la Rhétorique. Calliope I, París, 1979, pp. 239269.

MAYSER, E., Grammatik der griechischen Papyri aus der Ptolemäerzeit. Band I, Laut- und Wortlehre, II. Teil: Flexionslehre, Berlín, 1970a (=Berlín-Leipzig, 1938).

- Grammatik der griechischen Papyri aus der Ptolemäerzeit. Band II 1, Satzlehre, Berlín, 1970b (=Berlín-Leipzig, 1926).

MeILlet, A., Aperçu d' une histoire de la langue grecque, París, 1975 (=1965).

Morpurgo-Tagliabue, G., Demetrio: dello stile, Roma, 1980.

MÜLLER, W. G., «Der Brief als Spiegel der Seele. Zur Geschichte eines Topos der Epistolartheorie von der Antike bis zu Samuel Richardson», A\&A, 26, 1980, pp. 138-157.

MÜNSCHER, K., «Die Philostrate», Philologus, Supplementband, 10, 1907, pp. 469558.

Patillon, M., La théorie du discours chez Hermogène le Rhétour. Essai sur les structures linguistiques de la rhétorique ancienne, París, 1988.

PhiLlimore, J. S., Philostratus. In honour of Apollonius of Tyana, vol. I, Oxford, 1912.

Porter, S. E. (ed.), Handbook of Classical rhetoric in the Hellenistic period 330 $B C$ - AC 400, Leiden-Nueva York-Colonia, 1997.

Privitera, G. A. \& Pretagostini R., Storia e forme della letteratura greca, Milán, 1997.

RABE, H., «Aus Rhetoren-Handschriften», RhM, 64, 1909, pp. 284-309.

RAdermacher, L., Neutestamentliche Grammatik. Das Griechische des Neuen Testaments im Zusammenhang mit der Volkssprache, Tubinga, 1925.

- Koine, Viena, 1947.

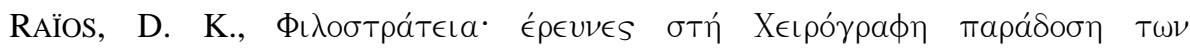

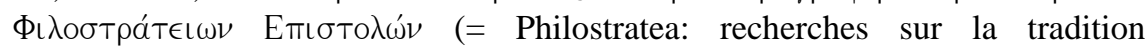
manuscrite des «Lettres» de Philostrate), Ioannina, vol. 1, 1992; vol. 2, 1997.

Reardon, B. P., Courants littéraires grecs des II et III siècles après J. C., París, 1971.

REED, J. T., «The epistle», en S. E. Porter, 1997, pp. 171-194.

ROBERTS, W. R., Demetrius on style, Hildesheim, 1969 (=Cambridge, 1902).

ROSENMEYeR, P. A., Ancient epistolary fictions: the letter in Greek literature, Cambridge, 2001.

Russell, D. A., Criticism in Antiquity, Londres, 1995 (=1981).

- «Greek criticism of the Empire», en G. A. Kennedy, 1989, pp. 297-329.

Monografías de Filología Griega 20. ISSN 1136-0860 
SCARPAT, G., «L'epistolografia», en Introduzione allo studio della cultura clasica I, Milán, 1972.

SCHADEWALDT, W., «Der Brief bei den Griechen. Ein Instrument des Humanen», en E. Hora \& E. Kessler (eds.), Studia Humanitatis. Ernesto Grassi zum 70. Geburtstag, Múnich, 1973, pp. 31-42.

SCHENKEVELD, D. M., Studies in Demetrius «On style», Amsterdam, 1964.

SchmID, W., Der Atticismus in seinen Hauptvertretern, I, Hildesheim, 1964a (=Stuttgart, 1887).

- Der Atticismus in seinen Hauptvertretern, II, Hildesheim, 1964b (=Stuttgart, 1889).

- Der Atticismus in seinen Hauptvertretern, III, Hildesheim, 1964c (=Stuttgart, 1893).

- Der Atticismus in seinen Hauptvertretern, IV, Hildesheim, 1964d (=Stuttgart, 1896).

- Der Atticismus in seinen Hauptvertretern, v, Hildesheim, 1964e (=Stuttgart, 1897).

SCHWYZER, E., Griechische Grammatik. Erster Band: Allgemeiner Teil. Lautlehre. Wortbildung. Flexion, Múnich, 1968 (=1953).

SchwyZer, E. \& DeBrunNer, A., Griechische Grammatik. Zweiter Band: Syntax und syntaktische Stilistik, Múnich, 1966.

SMYTH, H. W., Greek grammar, Cambridge (Massachusetts), 1984 (=1920).

SOLMSEN, F. «Philostratos», RE, 20, 1941, pp. 124-177.

SUÁREZ DE LA TORRE, E., «La epistolografía griega», EClás, 83, 1979, pp. 19-46.

- «Ars Epistolica. La preceptiva epistolográfica y sus relaciones con la retórica», en G. Morocho (ed.), Estudios de drama y retórica, León, 1988, pp. 177-204.

- «Motivos y temas en las cartas de amor de Filóstrato y Aristéneto», Fortunatae, 1, 1991, pp. 113-132.

SwaIN, S., Hellenism and Empire. Language, Classicism, and power in the Greek World, $A D$ 50-250, Oxford, 1996.

- «Culture and nature in Philostratus», en E. Bowie \& J. Elsner, 2009, pp. 3346.

THRAEDE, K., Grundzüge griechisch-römischer Brieftopik, Múnich, 1970.

UREÑA BRACERO, J., «La carta ficticia griega: los nombres de personajes y el uso del encabezamiento en Alcifrón, Aristéneto y Teofilacto», Emerita, 61, 1993, pp. 267-298.

- «Homero en la formación retórico-escolar griega», Emerita, 67, 1999, pp. 315-339.

- «El uso de fuentes literarias, recursos retóricos y técnicas de composición en etopeyas sobre un mismo tema», en E. Amato \& J. Schamp, 2005, pp. 93-111. 
ViCENTE SÁNCHEZ, A., «La expresión del lamento en la epistolografía griega de tema erótico-amoroso a la luz de las teorías retóricas griegas: las Cartas de Alcifrón», Myrtia, 19, 2004, pp. 69-102.

- Las Cartas de Temístocles. Lengua y técnica compositiva, Zaragoza, 2006.

- «La expresión del lamento en la epistolografía erótica y su relación con las enseñanzas retóricas: Claudio Eliano», en J. A. Fernández Delgado \& F. Pordomingo \& A. Stramaglia (eds.), Escuela y literatura en Grecia antigua, Edizioni dell' Università degli Studi di Cassino, Cassino, 2007, pp. 469-483.

WALKER, A., «Eros and the eye in the Love-Letters of Philostratus», PCPhS, 38, 1992, pp. 132-148.

WHITE, J. L., Light from ancient letters, Filadelfia, 1986.

WhitMarsh, T., «Prose literature and the Severan dynasty», en S. Swain \& S. Harrison \& J. Elsner (eds.), Severan culture, Cambridge, 2007, pp. 29-51.

WisSE, J., Ethos and pathos from Aristotle to Cicero, Ámsterdam, 1989.

WUELLNER, W., «Arrangement», en S. E. Porter, 1997, pp. 51-87. 


\section{Monografías de Filología Griega. Normas de publicación.}

Todas las monografías deben incluir un Abstract (breve resumen en inglés del contenido del volumen), un Index verborum y una Bibliografía general.

Tamaño del papel: ancho: $17 \mathrm{~cm}$.; alto: $23 \mathrm{~cm}$.

Tamaño del texto: ancho $12 \mathrm{~cm}$.; alto: $18 \mathrm{~cm}$.

Encabezado superior: a $1 \mathrm{~cm}$. del texto.

Folio numérico: tamaño 10 (página izquierda par; página derecha impar).

Folio explicativo: tamaño 8, mayúsculas, cursivas.

Encabezado inferior: a $0,7 \mathrm{~cm}$. del texto.

Título de la revista, número, ISSN: tamaño 8, minúsculas, cursiva.

Texto: fuente Times New Roman o Garamond; Unicode para los textos griegos.

Tamaño de la fuente: 11; párrafo: mínimo 13 puntos; sangría de párrafo de 0,6cm.; 6 puntos entre párrafos.

\section{Títulos de capítulos y partes:}

En página aparte:

tamaño 13, mayúscula, negrita, centrado y párrafo mínimo 15 puntos.

Dentro del texto:

primer rango: tamaño 11, mayúscula, negrita, centrado y párrafo 13 puntos

segundo rango: tamaño 11, minúscula, negrita, párrafo 13

tercer rango: tamaño 11, mayúscula, cursiva, párrafo 13.

Citas: tamaño de la fuente: 9; párrafo: mínimo 11 puntos; sangría de texto de 1,2 cm. (izda. y dcha.) y sangría de primera línea de 0,6 cm.; citas en párrafo aparte sin comillas; citas poéticas en párrafo aparte en letra redonda; partes omitidas indicadas con puntos suspensivos encorchetados [...].

Notas: tamaño de la fuente: 9; párrafo: mínimo 11 puntos; n. ${ }^{\circ}$ de nota con sangría primera línea $(0,6 \mathrm{~cm}$.) y tabulador texto $(1 \mathrm{~cm}$.).

Referencias bibliográficas: Sistema Harvard (autor-año).

Las referencias bibliográficas pueden insertarse en el texto o desplazarse a nota.

Autor, año, páginas (más de una obra en el mismo año se diferencia mediante una letra: 1995a, 1995b). Los signos que enlazan los datos son aleatorios:

A. López Eire, 1999, pp. 234 ss. / A. López Eire (1999, pp. 234 ss.).

Bibliografía final: tamaño de la fuente: 10; párrafo: mínimo 12 puntos; sangría francesa de 0,6 cm; apellidos en versalitas. Ejemplos:

ALY, W., «Herodots Sprache», Glotta, 15, 1926, pp. 84-118.

LÓPEZ EIRE, A. y C. SCHRADER, Los orígenes de la oratoria y la historiografía en la Grecia Clásica, Zaragoza, 1994.

Schrader, C., V. Ramón y J. Vela (eds.), Plutarco y la Historia. Actas del V Simposio

Español sobre Plutarco (Zaragoza, 20-22 de junio de 1996), Zaragoza, 1997. 



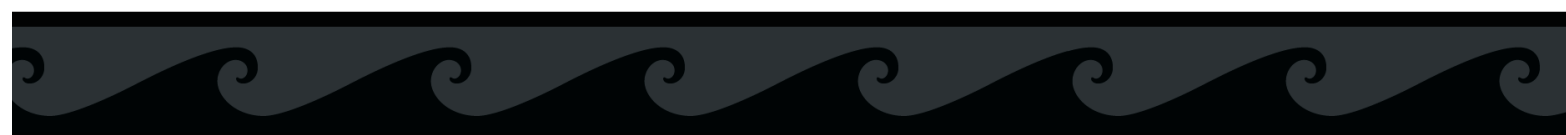

Las Cartas eróticas de Filóstrato constituyen una ventana abierta

a pequeños paisajes de la Grecia Arcaica y Clásica. Motivos

y tópicos amorosos de sabor agridulce hallan su inspiración

en temas que brillan en ese pasado dorado. Estas formas de

composición, las Cartas, deben sus peculiaridades a la moda

de su tiempo y a esa pericia retórica que caracteriza a sus

autores, quienes reflejan el movimiento cultural de toda una

época, la Segunda Sofística, mediante un retablo de personajes

y de situaciones refinadas. Se aborda igualmente el estudio

del complejo texto griego de nuestras Cartas, que trasluce

la realidad delicada, suavemente hedonista, de esta selección

de amores y desamores. En suma, he aquí un inventario

de textos para instrucción del lector ingenuo o doliente que,

hoy como ayer, se irá percatando del sentido inherente

a las pasiones ruinosas. 